\title{
Illinois Coal Reserve Assessment and Database Development: Final Report
}

Colin G. Treworgy

Eleanor I. Prussen

Michael A. Justice

Cheri A. Chenoweth

Margaret H. Bargh

Russell J. Jacobson

Heinz H. Damberger

prepared for

Energy Information Administration

U.S. Department of Energy

under cooperative agreement DE-FC01-94EI24855

1997

Open File Series $1997-4$

Department of Natural Resources

ILLINOIS STATE GEOLOGICAL SURVEY

William W. Shits, Chief

Natural Resources Building

615 East Peabody Drive

Champaign, Illinois 61820-6964

(217) 333-4747

Released by the authority of the State of Illinois / 1997

\section{DOE/EI/24855--T/}




\section{DISCLAIMIER}

Portions of this document may be illegible in electronic imige products. Irrages are produced from the best available original document. 


\section{DISCLAIMER}

This report was prepared as an account of work sponsored by an agency of the United States Government. Neither the United States Government nor any agency thereof, nor any of their employees, makes any wartanty, express or implied, or assumes any legal liability or responsibility for the accuracy, completeness, or usefulness of any information, apparatus, product, or process disclosed, or represents that its use would not infringe privately owned rights. Reference herein to any specific commercial product, process, or service by trade name, trademark, manufacturer, or otherwise does not necessarily constitute or imply its endorsement, recommendation, or favoring by the United States Government or any agency thereof. The views and opinions of authors expressed herein do not necessarily state or reflect those of the United States Government or any agency thereof. 


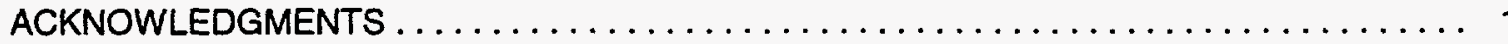

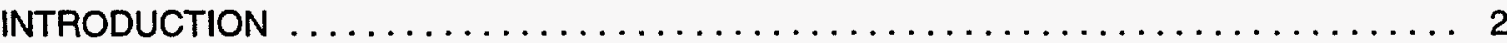

Purpose of Coal Reserves Database Studies . . . . . . . . . . . . . . . . . . . 2

Geology and Mining Practices of the Illinois Coal Field ................... 2

Previous Investigations of Illinois Coal Resources and Reserves .............. 3

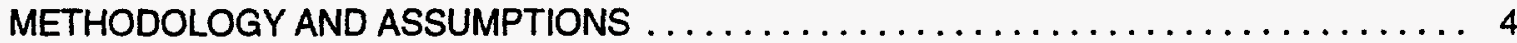

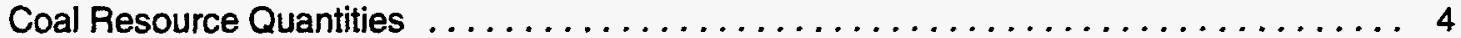

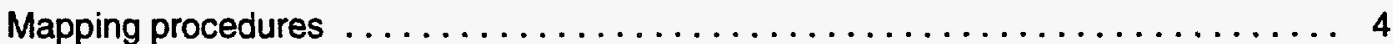

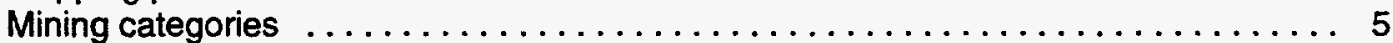

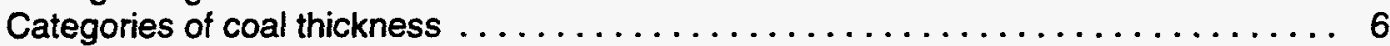

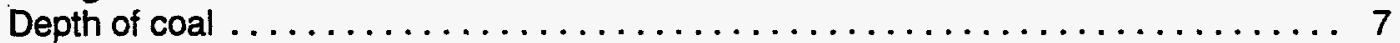

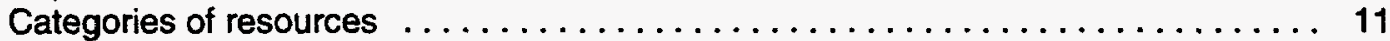

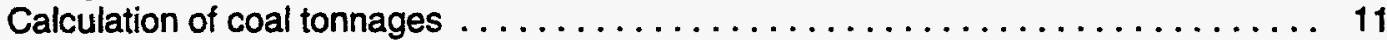

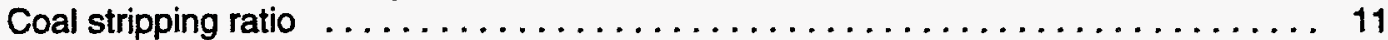

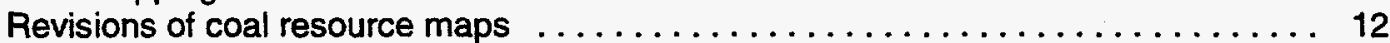

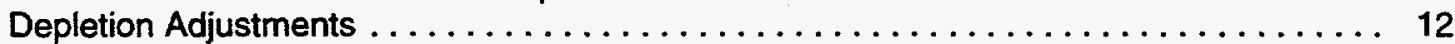

Mined areas . . . . . . . . . . . . . . . . . . 12

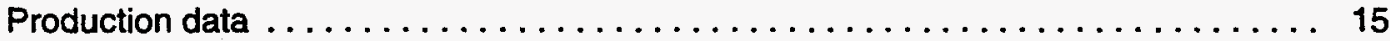

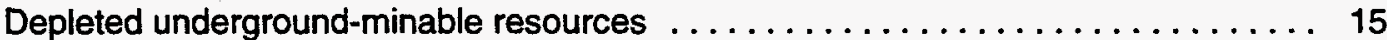

Cumulative production from surface mines $\ldots \ldots \ldots \ldots \ldots \ldots \ldots \ldots \ldots \ldots, 16$

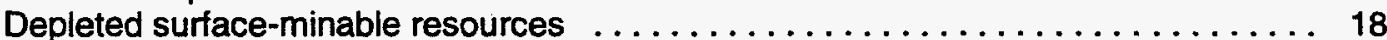

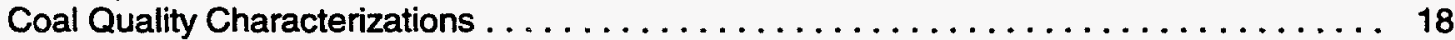

Data sources . .................................. 18

Quality of coal shipped by mines compared with that of face channel samples . . . . 19

Quality of coal producible from high- and low- to medium-sulfur reserves . . . . . . . 19

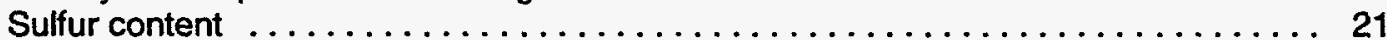

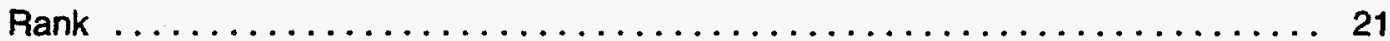

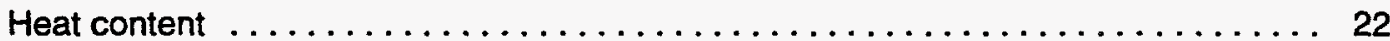

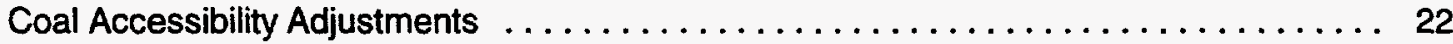

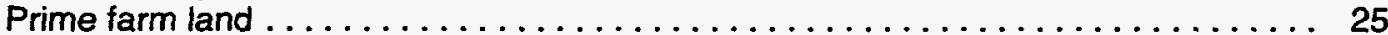

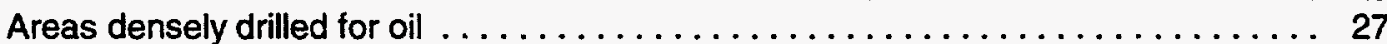

Underground-minable coal less than 42 inches thick $\ldots \ldots \ldots \ldots \ldots \ldots \ldots \ldots 28$

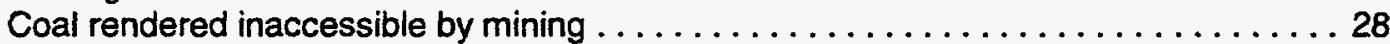

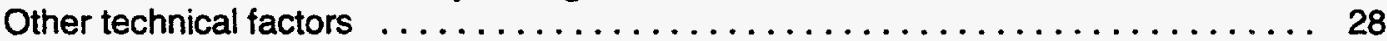

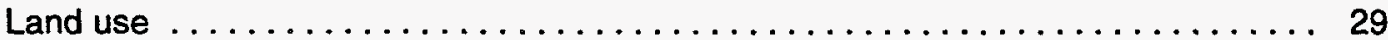

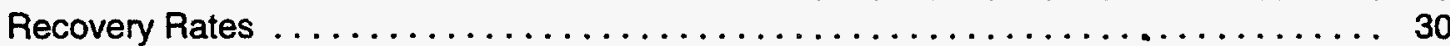

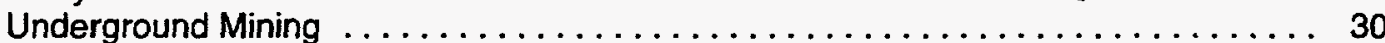

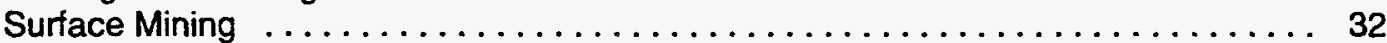

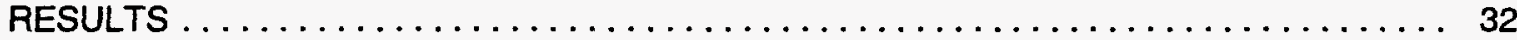

Demonstrated Reserve Base . . . . . . . . . . . . . . . . . . . . . . . . 32

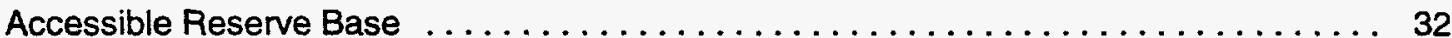

Recoverable Reserves . . . . . . . . . . . . . . . . . . . . . . . . . . . . 34

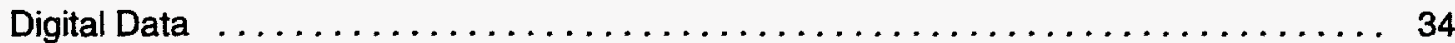

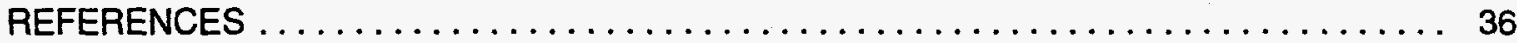

\section{APPENDIXES}

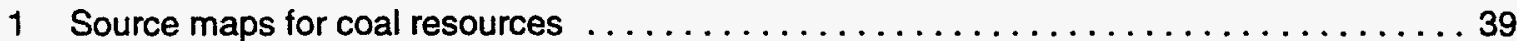

2 Assumptions used to allocate reported mine production to individual seams . . . . . . . 44

3 Factors used to calculate underground-minable reserves restricted by land use . . . . . 45

4 Remaining demonstrated reserve base in Illinois, January 1, 1996, in million short tons . . 47 
5 Formats of digital files of demonstrated reserves provided to the Energy Information Administration ...................................... 100

6 Procedures for revising estimates of coal resources $\ldots \ldots \ldots \ldots \ldots \ldots \ldots \ldots \ldots 101$

7 Formulas for calculating sulfur, heat content, rank, and stripping ratio $\ldots \ldots \ldots \ldots \ldots 105$

\section{FIGURES}

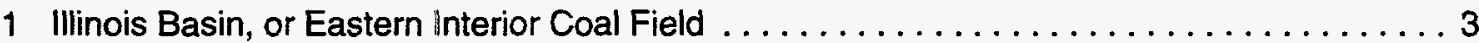

2 Stratigraphic position of coals mined or mapped as resources in Illinois . . . . . . . . . 4

3 Areas with surface-minable coal resources $\ldots \ldots \ldots \ldots \ldots \ldots \ldots \ldots \ldots \ldots \ldots, \ldots \ldots$

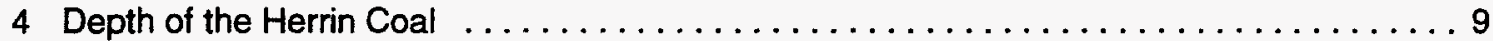

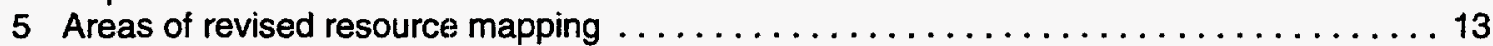

6 Locations of coal mines .................................... 14

7 Examples of changes in mine boundaries of two mines, January 1, 1979, to January 1, 1996 ............................................ 16

8 Base year of mapping of surface-minable coal resources $\ldots \ldots \ldots \ldots \ldots \ldots \ldots \ldots 17$

9 Sulfur and ash contents of low- to medium-sulfur coals $\ldots \ldots \ldots \ldots \ldots \ldots \ldots \ldots \ldots$

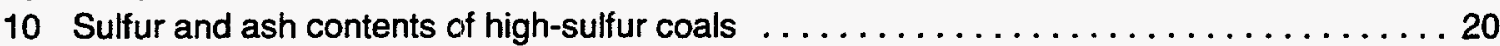

11 Locations of Herrin Coal samples analyzed to determine rank, sulfur content, and heat content . . . . . . . . . . . . . . . . . . . . . . . . . . . 23

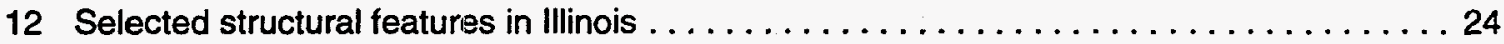

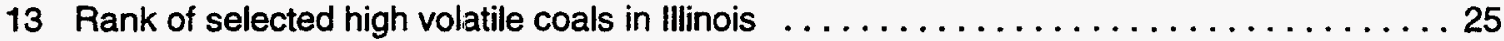

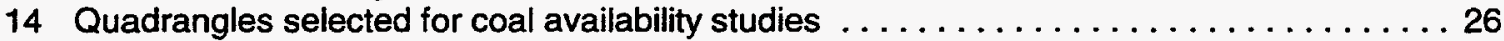

15 Availability of coal resources in eight quadrangles in Illinois . . . . . . . . . . . . . 27

16 Typical areas of unminable coal between and adjacent to two mines . . . . . . . . . . 29

A6-1 Examples of partings observed in mines or logs in the vicinity of the

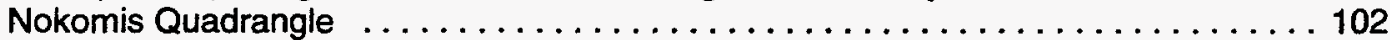

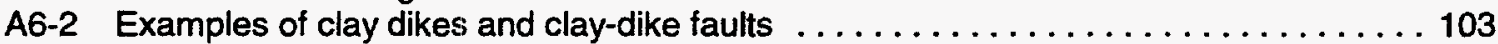

A6-3 Displacement of coal by faults ................................ 104

\section{TABLES}

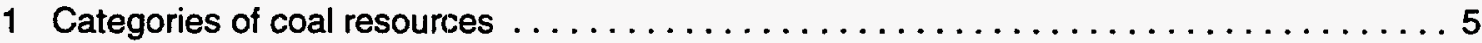

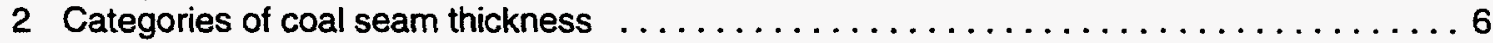

3 Categories of overburden thickness . . . . . . . . . . . . . . . . . . . .

4 Construction of depth maps for underground-minable reserves $\ldots \ldots \ldots \ldots \ldots \ldots \ldots 10$

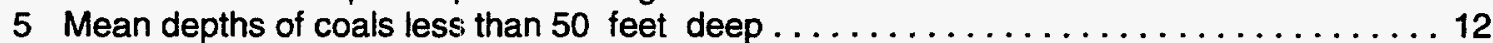

6 Types of analyses used to assess sulfur, rank, and heat content $\ldots \ldots \ldots \ldots \ldots \ldots 19$

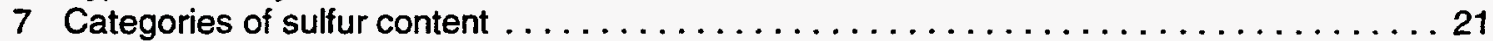

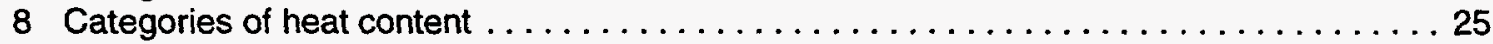

9 Factors considered and applied to the demonstrated reserve base to estimate the

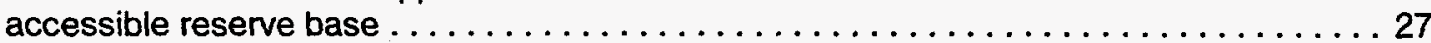

10 Depletion, production, and calculated recovery rate of underground-minable resources in selected counties from January 1,1979 , to January $1,1996 \ldots \ldots \ldots \ldots 30$

11 Depletion and production of underground-minable resources in selected counties

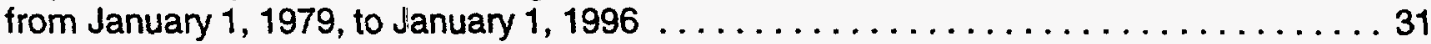

12 Depletion, reported production, and calculated recovery rates for surface-minable

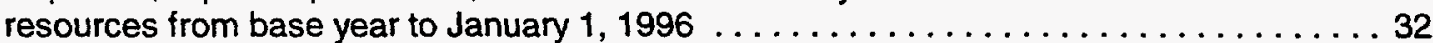

13 Cumulative surface-minable depletion and production from base year to

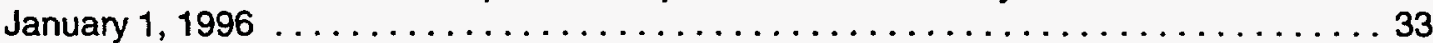

14 Summary of demonstrated reserve base in Illinois, January $1,1996 \ldots \ldots \ldots \ldots \ldots .34$

15 Summary of accessible reserve base in lllinois, January $1,1996 \ldots \ldots \ldots \ldots \ldots \ldots \ldots 35$

16 Summany of recoverable reserve base in Illinois, January $1,1996 \ldots \ldots \ldots \ldots \ldots \ldots . \ldots \ldots$ 


\section{EXECUTIVE SUMMARY}

The new demonstrated reserve base estimate of coal for Illinois is 105 billion short tons*. This estimate is an increase from the 78 billion tons in the Energy Information Administration's demonstrated reserve base of coal, as of January 1,1994 . The new estimate arises from revised resource calculations based on recent mapping in a number of counties, as well as significant adjustments for depletion due to past mining. The new estimate for identified resources is 199 billion tons, a revision of the previous estimate of 181 billion tons.

The new estimates incorporate the available analyses of sulfur, heat content, and rank group appropriate for characterizing the remaining coal resources in Illinois. Coal-quality data were examined in conjunction with coal resource mapping. Analyses of samples from exploration drill holes, channel samples from mines and outcrops, and geologic trends were compiled and mapped to allocate coal resource quantities to ranges of sulfur, heat content, and rank group. The new allocations place almost $1 \%$ of the demonstrated reserve base of Illinois in the two lowest sulfur categories, in contrast to none in the previous allocation used by the Energy Information Administration (EIA). The new allocations also place $89 \%$ of the demonstrated reserve base in the highest sulfur category, in contrast to the previous allocation of $69 \%$ in the highest category.

Depletion of reserves as calculated from maps of mined areas was compared to reported production and recovery rates. The comparison demonstrated some potential pitfalls of estimating depletion based on reported production and suggested the need for local knowledge of mine operations. Problems included production data that were reported on the basis of tipple location rather than point of extraction, depletion of surface-minable reserves by underground mines, and inability to estimate on the basis of reported data the destruction of reserves by preferential mining of lower seams.

The accessible reserve base is estimated to be 70 billion tons. The previous estimate of 56 billion tons excluded surface-minable coal under prime farm land, an exclusion that is no longer valid. The new estimate excludes reserves under towns, interstate highways, and public land; undergroundminable reserves thinner than 42 inches; reserves in small, irregular blocks between mines; and an allowance for coal left for barriers and small blocks in future mines. The Illinois State Geological Survey (ISGS) is currently conducting a multiyear study supported by the U.S. Geological Survey (USGS) to assess the availability of coal for mining. When complete, the findings from the coal availability studies are expected to lead to additional adjustments in the accessible reserve base.

Recoverable reserves, estimated to be 38 billion tons, were calculated using recoverability rates of $50 \%$ for underground-minable reserves and $70 \%$ to $85 \%$ (depending upon location and thickness) for surface-minable reserves. These percentages were selected after examining data on reserve depletion and mine production from January 1979 to January 1996. The recovery rates account for coal that will be lost in cleaning and handling or left as pillars or barriers in mines.

\section{ACKNOWLEDGMENTS}

The Illinois State Geological Survey entered into Cooperative Agreement DE-FC01-94El24855 with the Energy Information Administration (EIA) of the U.S. Department of Energy to update coal reserve estimates for lllinois.

The assistance of several people was critical to the completion of this report. Richard Harvey (ISGS) spent much of his career compiling and editing the database of coal analyses that provided the basis for our coal quality allocations. Jennifer Hines (ISGS) supervised the entry of the production and stratigraphic data used to calculate cumulative production and to revise resource maps. Richard Bonskowski (EIA) provided quality, production, and recovery data and helped to develop and refine the methodology for this project.

\footnotetext{
- All tonnages reported are in short tons (2,000 pounds).
} 
This project would not have been possible without the coal resource database developed for many years by ISGS staff with the financial and technical support of the Coal Branch of the U.S. Geological Survey. In particular, the National Coal Resources Data System and coal availability studies have been invaluable in advancing our knowledge of coal resources and reserves in Illinois.

\section{INTRODUCTION}

The Coal Reserves Data Base (CRDB) program involves authorities from regions with major coal resources in ElA's effort to update the national coal reserve data. This report describes the results of a two-part study in Illinois. It is the fifth study in EIA's program to update state-level reserve estimates in cooperation with a state geological survey.

The project ran from July 5, 1994, to January 3,1997 , and used funds furnished by the EIA and ISGS. EIA's funding was administered within two separate project periods. An interim report, Final Report for Part 1, was supplied to EIA in December 1995 and published by the ISGS as Open File Report 1995-11. The data in that report were used in updated demonstrated reserve base (DRB) and estimated recoverable reserve data released in EIA's report U.S. Coal Reserves: A Review and Update (EIA 1996).

The CRDB uses an updated set of criteria designed to be consistent nationally but flexible locally to accommodate variations in geology and mining practices. The CRDB program is needed because the traditional source of EIA coal reserve estimates, the DRB, was adapted from older published studies from various contributors, many of whom followed criteria somewhat different from those preferred for the DRB.

\section{Purpose of Coal Reserves Database Studies}

The CRDB data, intended for use in analyses of coal supply and to support analyses of policy and legislative issues, will be available to both government and nongovernment analysts. The data will also be part of the information used to supply U.S. energy data for international databases and to answer inquiries from private industry and the public.

The EIA recognizes that coal resource area maps, drilling records, historical mine boundaries, and site-specific analytical and geologic data are critical for reliable calculations of coal resource quantities. Such information has been used to various extents in the present study. In accordance with the terms of the CRDB program, the supporting data files and detailed documentation will remain at the ISGS, where they will be the basis for future updates and revisions, amplification with new data, or modification for other ISGS objectives. The EIA will maintain copies of the detailed database for counties and coal beds and selected source files.

The information in this report was compiled under guidelines that emphasize utilization of previously unexploited coal resource and coal analytical data that are immediately available and can be assimilated during a short-term project. Priority was given to revising seams with potential reserves of low to medium sulfur content or areas with significant new data.

\section{Geology and Mining Practices of the Illinois Coal Field}

Illinois has the second largest DFB of coal and largest DRB of bituminous coal in the nation (EIA 1996). The Illinois coal field in the Interior Region of the country consists of the western two-thirds of the Illinois Basin (or Eastern Interior Coal Field), which covers most of Illinois and western parts of Indiana and Kentucky (fig. 1).

Minable coal is found in the Pennsylvanian-age strata of the basin. The rank of these coals is high volatile bituminous, ranging from the A rank group at the extreme southern margin of the basin to rank groups $B$ and $C$ in the southern, central, and northern parts of the basin. The major coal seams crop out along the margins of the basin and dip gently to depths of more than 1,000 feet at the center of the basin in southeastern Illinois. Although the state has more than 60 named coal 


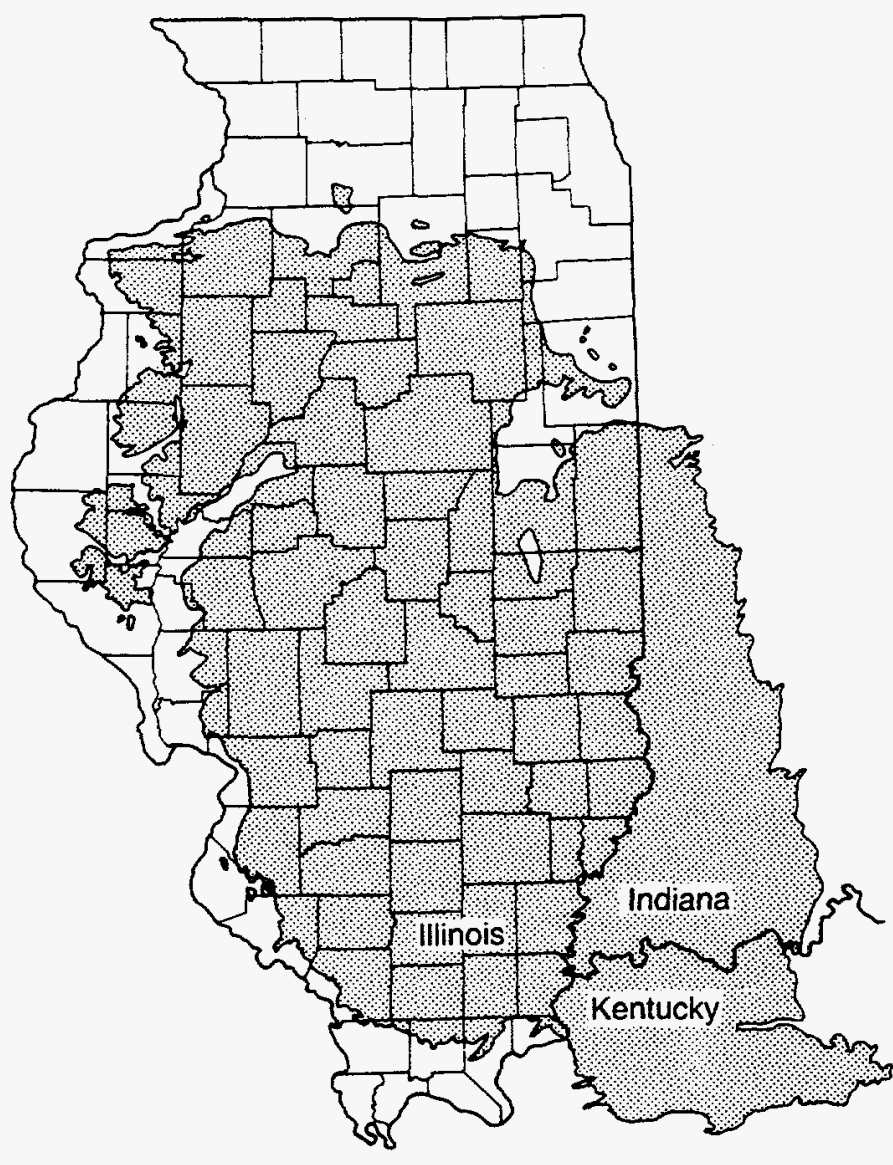

Figure 1 Illinois Basin, or Eastern Interior Coal Field. seams, this study reports on resources for 27 seams; $96 \%$ of the resources are concentrated in seven seams: the Danville (No. 7), Herrin (No. 6), Springfield (No. 5), Colchester (No. 2), Seelyville, Dekoven, and Davis Coals (fig. 2). A few other coals have been mined locally by small operations, but none of these resources have been mapped because of their limited extent.

Since the development of modern surface mining equipment, coals up to about 150 feet deep have commonly been mined by surface methods. Large dragline and shovel mining or small truck and shovel operations are the primary forms of surface mining. Augers and highwall miners are sometimes used to recover additional coal from the final cut of a surface mine.

Surface mine production peaked in Illinois in 1969 at almost 35 million tons (Illinois Department of Mines and Minerals [IDMM] 1994). Subsequently, production declined almost steadily to 7 million tons in 1995 . Although stricter reclamation requirements and weak demand for highsulfur coal have contributed to this decline, the major factor is believed to be depletion of low-cost reserves.

Shafts and slopes are the most common means of access to underground mines; but in a few cases, underground mines use a box cut or a drift entrance constructed at a surface mine highwall. Partial and high-extraction room-and-pillar mining and longwall mining methods are used.

During the past 10 years, production has shifted from entirely room-and-pillar mining to more than $30 \%$ from longwall operations. Annual production from underground mines rose from the 30 - to 40-million-ton range in the 1970 s and 1980s to a peak of 47 million tons in 1992. This production rate is expected to drop during the next few years as markets are lost as a result of Phase $I$ restrictions of the 1990 Amendment to the Clean Air Act and increasing price competition from western coals.

\section{Previous Investigations of Illinois Coal Resources and Reserves}

A report in 1913 (Campbell) estimated the original coal resources of llinois to be 200 billion tons. This estimate was based on very limited information and does not conform to current DRB criteria. Coincidentally, the 200-billion figure is remarkably close to the latest calculation of identified resources. Campbell's estimate, however, was based on a minimum thickness of 14 inches and did not use a minimum drill hole spacing. Using criteria comparable to Campbell's today, the original estimate of resources in the state would have exceded 300 billion tons.

In the early 1950s, Jack Simon and other members of the ISGS Coal Section staff under the general supervision of Gilbert Cady completed the first comprehensive survey of coal resources in the state (Cady 1952). This landmark report provided a framework and format generally followed in subsequent resource assessments. In particular, the report established categories of coal 


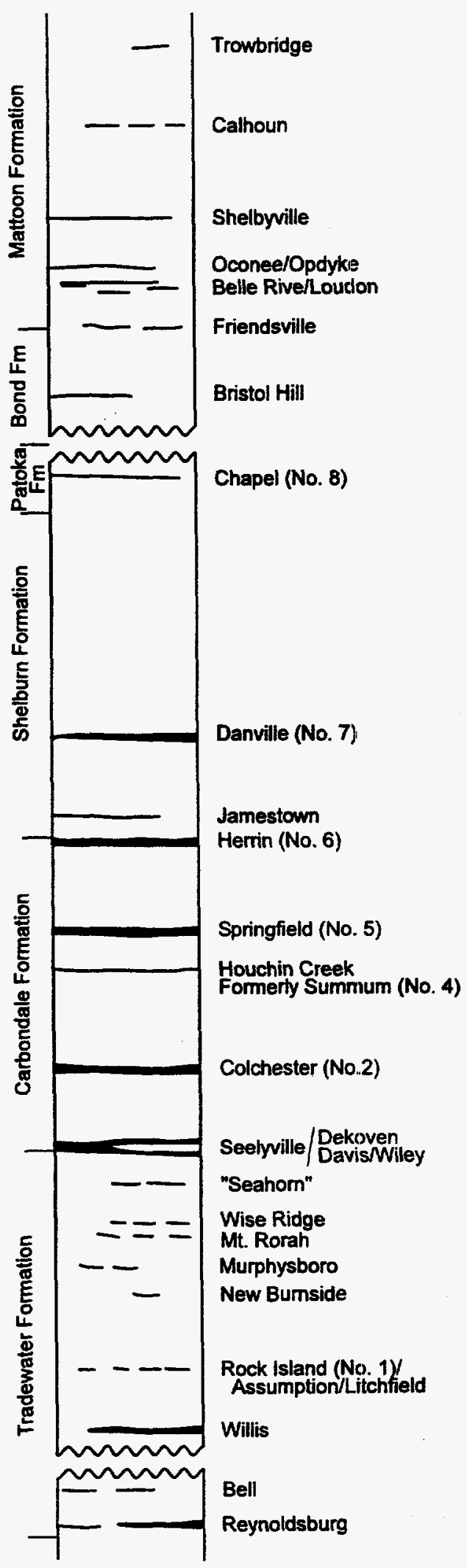

Figure 2 Stratigraphic position of coals mined or mapped as resources in Illinois. resources adapted to reflect the lateral continuity of most coals found in Illinois (table 1). This report is also the only source of resource and reserve estimates for a few seams in some counties that have not attracted sufficient interest to warrant revised mapping.

Although there were no agreed upon criteria for the concept of a DRB at the time of Cady's report, the criteria used in his study are compatible with current DRB definitions and indicated a DRB of 61 billion tons. Results from additional mapping since 1950 (minus depletions) raised the DRB to 78 billion tons (EIA 1995).

Prior to inclusion of any data from this present project, EIA's most recent DRB estimate for Illinois was based on a compilation of coal resources as of January 1, 1979 (Treworgy and Bargh 1982). Subsequent resource studies incorporated into this update are Jacobson (1983), Jacobson (1985), Jacobson (1993), and Treworgy (1995).

\section{METHODOLOGY AND ASSUMPTIONS}

The primary task of this project was to use existing data to update the DRB and allocate coal reserves by depth and quality of the resource. Coal resources were revised for seams in counties where significant new data were available.

\section{Coal Resource Quantities}

Coal resource quantity data were compiled from published and unpublished maps developed by ISGS geologists from several sources: drilling logs, core descriptions, and geophysical logs obtained from companies, as well as descriptions of mine and outcrop exposures made by ISGS geologists. Appendix 1 documents the information sources used for resources for each seam in each county.

Mapping procedures Past ISGS studies have demonstrated the utility of computers and digital databases for reserve assessments (e.g., Treworgy and Bargh 1982). Computers expedite merging coal thickness data with data on coal depth, sulfur, rank, heat content, and mined areas, and with other information such as calculation of depletion, accessibility, and recoverability of reserves. Future updates, revisions, and accessibility adjustments can also be made more efficiently with a digital database. 
Table 1 Categories of coal resources (modified from Cady 1952).

\begin{tabular}{llll}
\hline Class & $\begin{array}{l}\text { Maximum } \\
\text { distance from } \\
\text { data points }\end{array}$ & Accepted data points & Remarks \\
\hline $\begin{array}{l}\text { I-A } \\
\text { (Measured) }\end{array}$ & 0.5 mile & $\begin{array}{l}\text { Mined-out areas } \\
\text { Diamond drill holes } \\
\text { Outcrops } \\
\text { Coal test geophysical logs }\end{array}$ & $\begin{array}{l}\text { Approximately equivalent to } \\
\text { measured category of the } \\
\text { U.S. Geological Survey }\end{array}$ \\
$\begin{array}{l}\text { I-B } \\
\begin{array}{l}\text { Probable } \\
\text { (Indicated) }\end{array}\end{array}$ & 2 miles & $\begin{array}{l}\text { All points of class I-A plus coal- } \\
\text { test chum drill holes }\end{array}$ & $\begin{array}{l}\text { Approximately equivalent to } \\
\text { indicated category of the } \\
\text { U.S. Geological Survey }\end{array}$ \\
$\begin{array}{l}\text { II-A } \\
\text { Strongly Indicated } \\
\text { (Inierred) }\end{array}$ & 4 miles & $\begin{array}{l}\text { All points of classes 1-A and I-B } \\
\text { plus churn drill holes drilled for } \\
\text { oil or water with unusually good } \\
\text { records, control rotary drill holes, } \\
\text { and oil-test geophysical logs }\end{array}$ & $\begin{array}{l}\text { Approximately equivalent to } \\
\text { inferred category of the U.S. } \\
\text { Geological Survey }\end{array}$ \\
\hline
\end{tabular}

" Distances modified in practice by geological considerations.

Many of the coal resource maps needed for this study were already in some digital format. All data were combined into a single digital map database designed to facilitate processing for this study, as well as to provide a suitable foundation for future updates and revisions. All remaining paper maps were digitized into this common database.

When this digital database was created, a number of changes that were made to the data resulted in variations of the tonnages calculated from the original paper maps, even in cases for which no mining or new mapping has taken place. For example, most of the coal resource maps created or published before the 1980 s were based on USGS 15-minute topographic maps, which are less accurate than current 7.5-minute base maps. In constructing the digital database, all maps were converted to a 7.5-minute base. Because the area and shape of each county is slightly different on each of the base maps, the conversion from one base to another inevitably results in a small increase or reduction in area and therefore in coal tonnage.

Adjustments were commonly necessary where areas covered by two studies met or overlapped. A number of studies mapped either surface-minable or underground-minable coal, separating surface- from underground-minable coal at a depth of 150 feet. The 150-foot-depth line used to form the boundary for underground- or surface-minable coals often varied slightly among studies of adjacent or common areas. The 150-foot-depth line had to be modified to combine the results from the studies and create a seamless digital database. In most cases, the 150-foot-depth line used in the surface-minable resource studies was more detailed and accurate. This line was retained, and data from the adjoining study of deeper coal were modified.

Mining categories Resources and reserves are divided into categories on the basis of the mining method most likely to be used to extract the coal. The two categories used for this study are surface minable and underground minable. A few companies use augering or highwall mining to extract coal beyond the last cut of a surface mine, and at least one company has used augering in an underground mine. Highwall mining, as recently practiced in llinois, uses a remote-controlled continuous miner and a "train" of conveyor belts to mine straight, unsupported entries for about 800 feet in from a highwall. Because augering and highwall mining are not widely practiced in Illinois and their use is largely dependent upon circumstances at individual mines (e.g., the location of their lease boundary relative to the last practical highwall position), no separate category of resources could be defined for these mining methods.

The surface-minable category consists of coals most likely to be mined by removing the overburden to expose and mine the coal. In Illinois, this is commonly done by some combination of draglines, shovels, bucket wheel excavators, trucks, and scrapers. The underground-minable category consists 
of resources that will be extracted by underground methods such as room-and-pillar or longwall mining. Access to the seam may be by drift, highwall exposure, box cut, slope, or shaft.

The factors that determine the method used to mine a particular deposit are commonly economic rather than technical. The main factors are thickness and depth of the coal, average stripping ratio of the mine block, nature of the overburden material (which may determine the amount of blasting required), surface ownership and land use, proximity to other surface features, and the capital and previous mining experience of the company.

In Illinois, the 150-foot-depth line, although arbitrary, is a workable delimiter between surfaceminable and underground-minable resources. A few surface mines have mined small areas of deeper coal. More commonly, underground mines have mined shallower areas. In most cases, these underground mines are located where the greater portion of the reserve block is deeper than 150 feet, where surface land use or ownership makes surface mining impractical, or where existence of an abandoned highwall provides inexpensive access to a small, otherwise inaccessible block of coal. These exceptions are determined by local conditions, land ownership, company policy, and other circumstances that cannot be considered in regional assessments such as this study.

Surface-minable resources are clefined by ISGS convention to have a minimum thickness of 18 inches. Underground-minable resources are defined to have a minimum thickness of 28 inches. These minimum thicknesses have been used by the ISGS since the 1950 s and are based on historical mining practice in the state. For econornic reasons, seams less than 42 inches thick have not been extensively mined underground in llinois for the past three decades or more; however, reserves less than 42 inches thick have been retained in the DRB for this study in order to be comparable with current DRB estimates of other midwestern states. As explained below, these thin reserves are excluded from the accessible reserve base.

No maximum depth was established for underground-minable reserves. The deepest mapped resources in the state are slightly more than 1,500 feet deep. Interviews with representatives of mining companies indicated that this depth does not prevent mining of the coal.

Categories of coal thickness In Illinois, coal resources have commonly been mapped and reported in categories of 1 -foot increments of seam thickness (table 2). The two thinnest categories, 18-28 and 28-42 inches, deviate from the 1-foot increment in order to correlate more closely with national reporting categories of 14-28 and 28-42 inches used by the EIA and the

Table 2 Categories of coal seam thickness

\begin{tabular}{cc}
\hline $\begin{array}{c}\text { Category } \\
\text { in inches }\end{array}$ & $\begin{array}{c}\text { Average } \\
\text { thickness } \\
\text { in feet }\end{array}$ \\
\hline $18-28$ & $2^{*}$ \\
$28-42$ & 3 \\
$42-54$ & 4 \\
$54-66$ & 5 \\
$66-78$ & 6 \\
$78-90$ & 7 \\
$90-102$ & 8 \\
$102-114$ & 9 \\
$>114$ & 10 \\
\hline
\end{tabular}

* Surface-minable coal only.

USGS. In practice at the ISGS, consistent 1-foot increments (18-30 and 30-42 inches) have been used for most mapping of surface-minable coal and most recent mapping of undergroundminable coal. The 1-foot increments are preferred by the ISGS because their consistency facilitates the use of computers to map resources. For comparability with national reporting categories, these 1 -foot-increment tonnages are reported as the 18-28 and 28-42-inch categories.

The most recent mapping, completed for this report, contoured resources on 6-inch increments (e.g., 30-, 36-, 42-, and 48-inch contours, etc.). For reporting purposes in this report, these data are aggregated to EIA's 12-inch categories, but the 6-inch thickness categories are retained in the digital database that accompanies this report.

Some surface-minable resources and resources from older studies of underground-minable coal are mapped using categories of average thickness that do not correspond to the standard 12-inch increments; for example, an area of resources may be classified as "averages 20 inches." The original thickness categories mapped have been retained in the digital database produced for this study. 
Clean coal thickness (coal only, with partings excluded, as opposed to raw coal thickness or total seam thickness) was mapped in the areas revised for this study. It has been standard USGS practice for many years to exclude partings thicker than $3 / 8$ inch from seam thicknesses used to calculate tonnages (Averitt 1969, Wood et. al. 1983). Many older ISGS resource studies do not document whether clean coal or raw seam thickness was mapped. However, all ISGS studies have used a density of 1,800 tons per acre foot (the standard density for clean bituminous coal), which indicates that the thickness for clean coal was mapped.

A more serious problem is that information on thin partings is not available from many logs. Many drilling logs report only major partings (e.g., 2 inches or more thick). Thin partings are sometimes difficult to recognize in cores and may even be undetectable on the types and scales of geophysical logs commonly run on coal test holes. Only major partings have been excluded from thickness measurements from oil test geophysical logs (because of the type and scale of log commonly used). Resources based on these data are assigned to the class II (inferred) category.

Mitigating this measurement problem somewhat is the fact that the major Illinois coals tend to be relatively free of partings. Errors in thickness caused by lack of information about partings should amount to no more than $2 \%$ or $3 \%$ and are on the same order of magnitude as other uncertainties in measuring thickness (e.g., loss of core material, determination of bed boundaries on geophysical logs, or rounding of measurements by drillers). Given these uncertainties as well as the uncertainties and assumptions associated with contouring and calculating tonnages, the lack of detailed data on partings is not a significant influence on the reserve tonnages calculated for this report.

Depth of coal Coal resources in Illinois have been mapped to depths of more than 1,500 feet. Surface-minable coals are found throughout the state (fig. 3 ). The major seams such as the Herrin Coal crop out and remain at shallow depths at the margins of the basin and dip toward the center of the basin in southeastern Illinois (fig. 4).

Information on the depth of resources was compiled in one of three ways. (1) Depth of surfaceminable resources was digitized from maps prepared for previous studies. (2) Depth of undergroundminable resources was taken from generalized, statewide maps created from point-source data. (3) For coal seams that were revised in the second year of this study (the majority of which were greater than 150 feet deep), depth was mapped using all available point-source data (e.g., drill holes and mine shafts).

Surface-minable resources are classified into three categories with 50 -foot increments of overburden $(0-50,50-100$, and 100-150 ft). Underground-minable resources (coal deeper than 150 feet) are classified into even 100-foot increments, except for the shallowest category of 150-200 feet. The depths of coals revised for this project were mapped using 25-foot increments. For reporting purposes, these have been aggregated into the broader categories given in table 3. The digital data supplied to EIA retain the more detailed depth categories.

The surface-minable depth categories, which were digitized from previous studies, are more accurate than the underground-minable categories. The shallow categories were mapped manually by overlaying a structure map of the coal seam with a topographic map of the land surface. The depth measurements reflect relatively detailed variations in surface topography and are suitable for calculating stripping ratios.
Table 3 Categories of overburden thickness

\begin{tabular}{cc}
$\begin{array}{c}\text { Underground } \\
\text { mining } \\
\text { in feet }\end{array}$ & $\begin{array}{c}\text { Surface } \\
\text { mining } \\
\text { in feet }\end{array}$ \\
\hline $150-500$ & $0-50$ \\
$500-1,000$ & $50-100$ \\
$1,000-2,000$ & $100-150$ \\
\hline
\end{tabular}




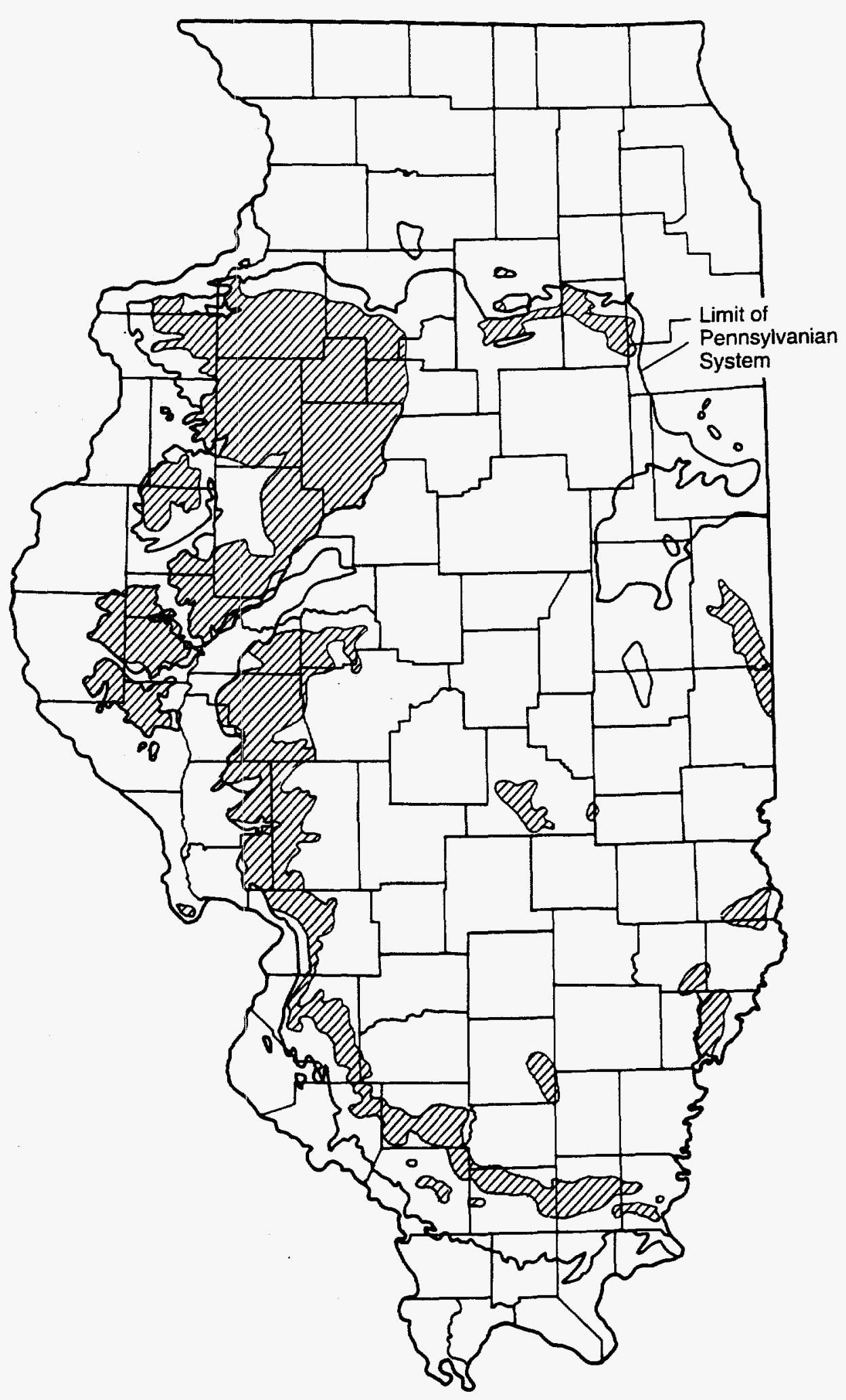

Figure 3 Areas with surface-minable coal resources. 


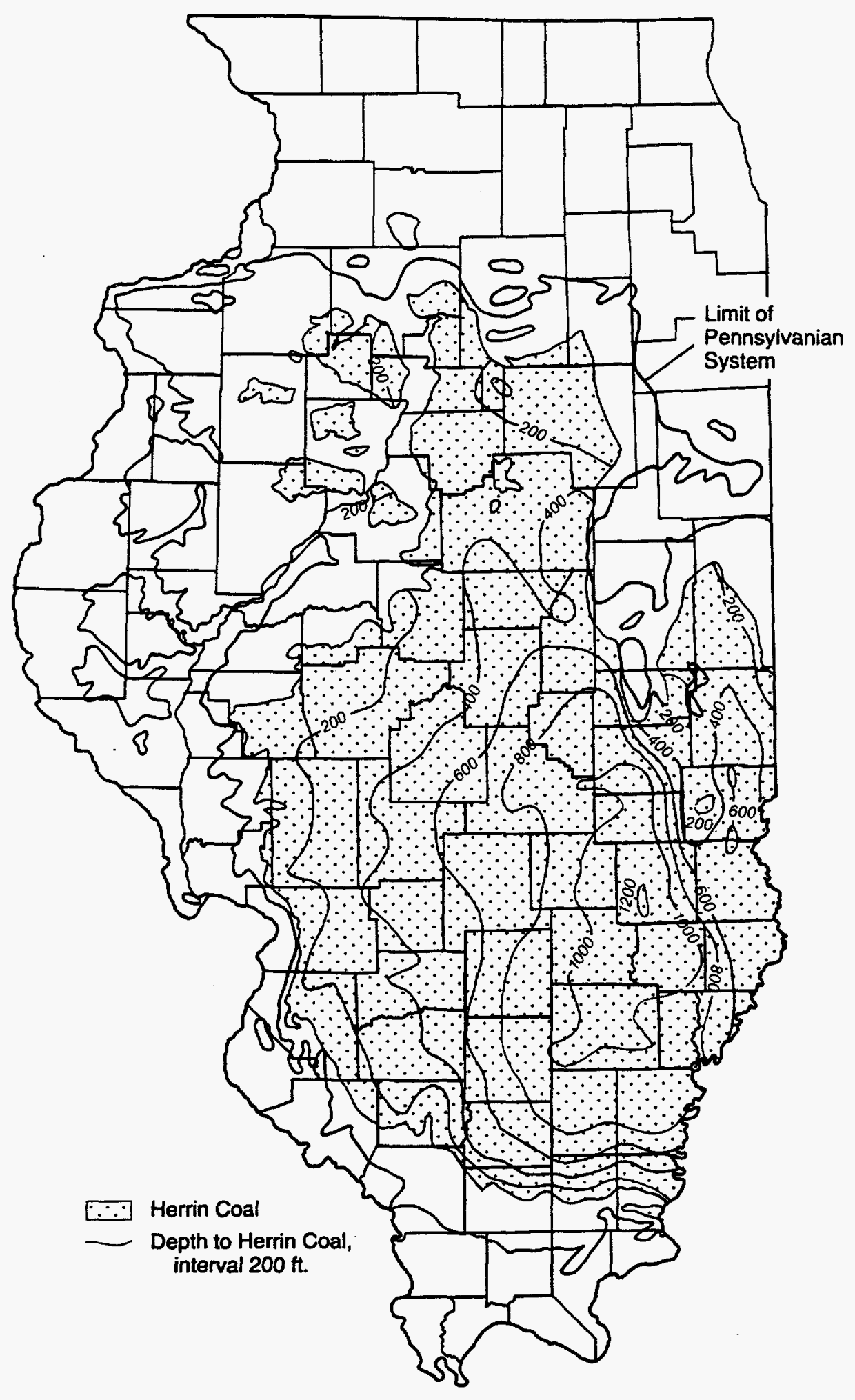

Figure 4 Depth of the Herrin Coal (from Smith and Stall 1975). 
The underground-minable categories were mapped by contouring coal depths from point-source data. This procedure delineates broad, regional trends in depth, but ignores changes in depth caused by abrupt, localized changes in topography or coal structure (e.g., a deeply cut river valley or a fault). In Illinois, local changes in depths of seams due to topography and structure are relatively minor and need not be considered from the regional perspective of this study.

The point-source data were extracted from the ISGS stratigraphic database, a collection of logs obtained from companies and interpreted by ISGS geologists. The existing data are believed to be adequate for the accuracy needed for this study, and no new data were compiled for this purpose (table 4). The average density of data points for most seams was lower than one per square mile. However, the actual data density varied considerably across the state from tens of points per square mile to less than one point per tens of square miles. Contours were constructed using software from a commercial vendor (Earthvision version 3.0 by Dynamic Graphics, Inc. Alameda, CA) and carefully reviewed for accuracy by a geologist. A grid consisting of 5,000 $\times 5,000$ foot cells (approximately 1 square mile) was used for contouring the statewide maps. This grid size represents regional trends, but generalizes areas with high data densities. The grids were contoured at a scale of $1: 50,000$. Although no paper maps were produced at this scale, the digital contour lines are smooth at this scale. Localized details that were not substantiated, given the data and assumptions used to create the final work maps, were eliminated by deleting contours enclosing areas less than about 9 square miles (map coordinates were in feet, so the actual value specified in the mapping procedure was 250 million square feet).

Information about the depth of overlying or underlying beds provided additional control for some coals. For example, the number and distribution of data points for the Herrin Coal were adequate to delineate the major structural features of the bed. However, fewer control points were available for the underlying Houchin Creek Coal, so the depth of the Houchin Creek resources was usually classified by adjusting the contours of the Herrin Coal by the approximate thickness of the stratigraphic interval between the two coals. Likewise, the Jamestown Coal is commonly 5 to 20 feet above the Herrin Coal, so its resources were assigned the same depth as the Herrin Coal.

The procedure for mapping depths of coals in counties where resources were revised in the second part of this project was similar to that described above. Because the amount of data available was generally greater in these counties and more time could be spent in verifying local anomalies, a grid of $1,000 \times 1,000$ foot cells was used and the minimum area enclosed by contours was about 90 acres (4 million square feet). The grids were contoured at a scale of 1:24,000.

Table 4 Construction of generalized, statewide depth maps for underground-minable reserves.

\begin{tabular}{|c|c|c|c|}
\hline Coal & $\begin{array}{l}\text { Number of } \\
\text { points used }\end{array}$ & $\begin{array}{c}\text { Data points } \\
\text { per square mile }\end{array}$ & Additional control \\
\hline $\begin{array}{l}\text { Danville } \\
\text { Jamestown }\end{array}$ & 9,185 & 0.4 & $\begin{array}{l}\text { Not allowed to be deeper than Herrin } \\
\text { Assigned same depth as Herrin }\end{array}$ \\
\hline Herrin & 17,371 & 0.7 & \\
\hline $\begin{array}{l}\text { Springfield } \\
\text { Houchin Creek } \\
\text { Survant }\end{array}$ & 10,106 & 0.4 & $\begin{array}{l}\text { Minimum } 20 \text { feet below Herrin } \\
\text { Depth assigned based on Herrin } \\
\text { Depth assigned based on Springfield }\end{array}$ \\
\hline $\begin{array}{l}\text { Colchester } \\
\text { Seelwille }\end{array}$ & $\begin{array}{l}6,794 \\
1,510\end{array}$ & $\begin{array}{l}0.3 \\
0.4\end{array}$ & Minimum 100 feet below Springfieid \\
\hline $\begin{array}{l}\text { Davis } \\
\text { Assumption }\end{array}$ & 2,659 & 1.2 & $\begin{array}{l}\text { Not allowed to be shallower than Colchester } \\
\text { Not gridded; depth for this area estimated from } \\
\text { three drill holes }\end{array}$ \\
\hline Murphysboro & 112 & 0.2 & \\
\hline
\end{tabular}


Categories of resources The ISGS resource categories used for this study (table 1) are comparable to those defined by the USGS. Because of the considerable lateral continuity of most Illinois coals, however, the radius of influence assigned to each data point is larger than that used by the USGS. The ISGS categories of class I-A, I-B, and II-A are considered equivalent to the USGS categories of measured, indicated, and inferred resources, respectively. The ISGS categories were originally defined by Cady (1952) and were modified by Treworgy and Bargh (1982) to include oil test geophysical logs as accepted data points for class II-A.

The criteria are further modified by this study to include, at the geologist's discretion, coal test geophysical logs as acceptable data points for class I-A. The suite of logs run for coal exploration commonly includes single point resistivity, gamma, density, and caliper. The logs are typically plotted at a scale of 1 inch equals 20 feet, with expanded sections of 1 inch equals 1 foot for major coals.

Calculation of coal tonnages Coal tonnages are calculated using a density of 1,800 tons per acre per foot of coal thickness (equivalent to 1.32 specific gravity). This is the average density commonly used for bituminous coals (Wood et al. 1983). The mean value of the two contours defining an area is used for this calculation. For example, the area between the 5.5-foot and 6.5-foot isopachs is assumed to have an average thickness of 6 feet.

As noted previously, the coal thickness isopachs represent clean coal. Consequently, the tonnage calculated represents clean coal in the ground. This is the standard figure reported by the USGS, EIA, and state geological surveys and should not be confused with tonnages of raw coal reserves commonly reported in engineering studies or company reports.

Improved accuracy in the base maps used caused the coal tonnages calculated for seams in some areas to differ from previous reports, even where no mining or new resource mapping had taken place. Tonnages also changed because the procedures for calculating areas changed. Prior to the late 1970s, all areas were measured by planimeter or a point-counting method. The 1979 update of underground-minable resources used geographic information system (GIS) software to compute areas and volumes (Treworgy and Bargh 1982). The GIS software, developed by the ISGS specifically for that project, used 10-acre grid cells $(660 \times 660 \mathrm{ft})$ to represent areas, thus limiting resolution of features to 660 feet.

The present study used a commercial GIS package that represents features as vectors or polygons (Arc/Info version 7.04 by Environmental Systems Research Institute, Redlands, CA). Areas are calculated using a proprietary algorithm. Because of the differences in the way features are represented and the way algorithms are used to compute areas, the areas (and consequently volumes) calculated by the two methods differ by a few percent. The vector representation used for the present study is inherently more precise than the grid representation used by earlier software.

Coal stripping ratio Average and maximum stripping ratios (cubic yards of overburden per ton of coal) were calculated for the three depth categories of surface-minable resources (coals less than 150 feet deep). The formula for the ratios is given in appendix 7 , and the ratios calculated are reported in the digital database produced for this project (see appendix 5).

The average stripping ratio was calculated by assuming that the coal tonnages in the 50-100 and 100-150 foot depth categories would be evenly distributed between the two extremes of depth and have average depths of 75 and 125 feet, respectively. The coal tonnage in the $<50$ foot depth category was assumed to be proportionally greater in the deeper half of the depth category, because most of the state is covered with glacial drift at least 20 feet thick. The average coal depth in the $<50$ foot category was assumed to be 35 feet.

These assumptions were confirmed by examining the coal depths in the ISGS database of drilling records. The averages in the three depth categories were 34,75 , and 125 feet. The points in the $<50$ foot depth category were examined for selected counties to see if the average coal depth varied by region. No significant difference in average depth was observed (table 5). 
The maximum stripping ratio is the theoretical maximum ratio that could be encountered mining resources with a particular combination of thickness and depth. For example, resources in the 48-inch thickness and 50-100 foot depth categories can be as thin as 42 inches and as deep as 100 feet, which yields a maximum stripping ratio of 25.6 cubic yards per ton.

\section{Revisions of coal resource} maps The ISGS continually receives new data on coal thickness from coal companies, consultants, government agencies, and other sources. Resource estimates were revised for coal seams in selected counties where significant new data had become available since the latest coal resource maps were compiled. Project funding precluded revising all counties where new data were available. Priority was given to revising maps of seams that had lower sulfur contents or that would significantly add to the DRB. Resource calculations were revised for four seams in 18 counties (fig. 5). The procedures described in appendix 6 were used for all these revisions except for the Herrin Coal in Macoupin and Montgomery Counties. Because of time constraints, the Herrin Coal thickness was revised only in selected areas of these counties. In these counties, new points were posted on the existing resource map, and contours edited by a geologist to fit the new data. Appendix 1 also indicates those seams and counties for which new data are available, but whose resources have not yet been revised.

\section{Depletion Adjustments}

Information on mined areas and production was compiled to update the DRB to January 1, 1996, and to provide EIA with comparative statistics on reported production and depletion of reserves.

Mined areas Coal mining began in llinois as early as 1810 . Few maps exist of mines that operated prior to the late $1890 \mathrm{~s}$, but the undocumented area of depleted resources is believed to be relatively small. Through the efforts of the U.S. Bureau of Mines, Illinois Office of Mines and Minerals, and ISGS, a fairly complete record of major mining operations has been preserved. This record includes maps of mine workings or approximate areas of mining of more than 2,100 underground and 400 surface mines.

The ISGS maintains a digital database of the extent of these mined-out areas in Illinois (fig. 6). The database also contains point locations for an additional 2,500 mines for which no map of the extent of mining is available. These mines are believed to be mostly small, short-term operations that affected very small areas.

Information on the extent of mines is obtained from maps provided by mining companies or from secondary sources, such as private compilations made for banks or insurance companies. In the few cases for which no maps are available, the mined areas have been estimated from reported production. Prior to 1984, the exterior boundaries of mined areas were compiled on 1:62,500-scale base maps and then digitized. Since 1984, mine boundaries and large interior areas of unmined coal have been digitized directly from the original mine maps or obtained in a digital format directly from the mining company. In most cases, the newer outlines are at a scale of 1:12,000 or larger. 

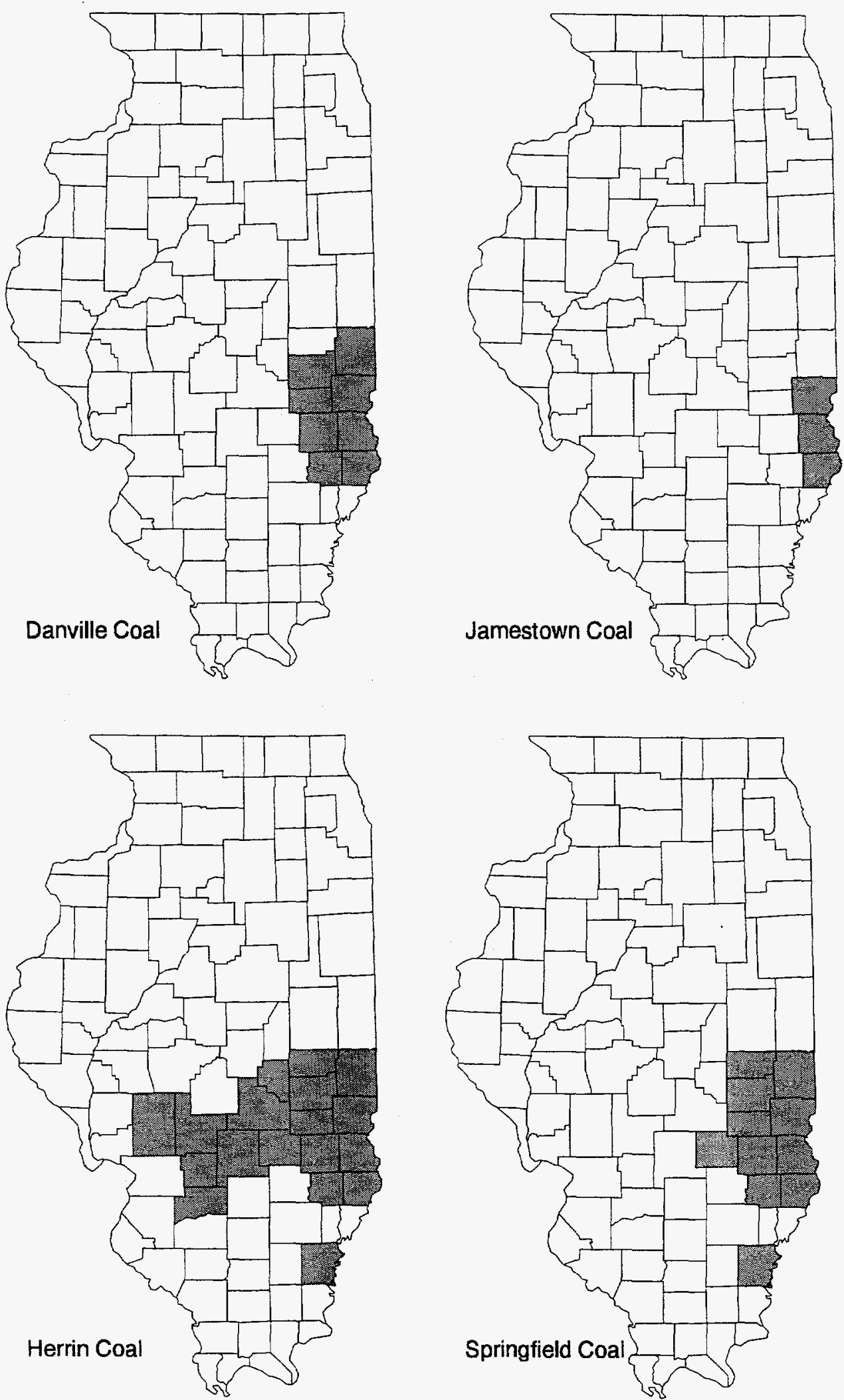

Figure 5 Areas of revised resource mapping. 


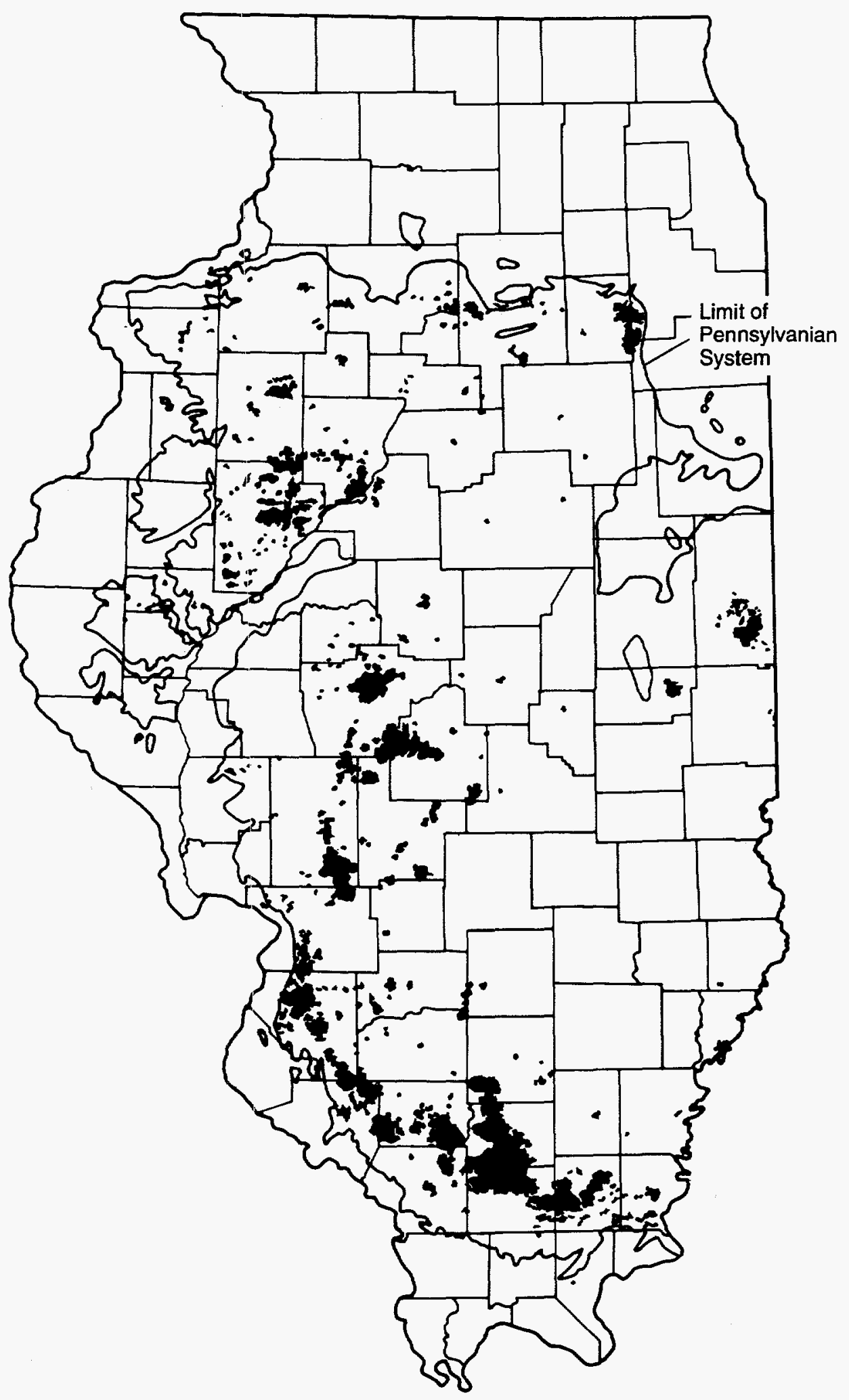

Figure 6 Locations of coal mines. 
For this study, the database was updated using paper or digital maps obtained from mining companies. Boundaries of active mines were updated to January 1, 1996, and the boundaries of numerous abandoned mines were revised to incorporate corrections or additional detail.

Some coal left around abandoned mines has been excluded from resources because of mining laws or practical considerations. Illinois law requires that a barrier pillar at least 200 feet wide be left between mines. In many cases, larger blocks of unmined coal have been left because of geologic conditions, ownership issues, or the geometric layout required for face or pit operations. Although wider than 200 feet, these unmined blocks are often too small or convoluted to be extracted by an adjacent mine.

These blocks of unminable coal between underground mines were excluded from resource tabulations in the 1979 estimate; however, barrier pillars created between mines since 1979 are included in the estimate of resources or DRB-a measure taken to conform with the USGS and EIA definitions of resources and reserves. This tonnage has been excluded from the accessible reserve base (see Coal Accessibility Adjustments section below).

Production data Data on annual coal production were obtained from annual reports published by the Illinois Office of Mines and Minerals (IOMM) of the Department of Natural Resources. Prior to 1917 , these reports were published as the biennial report of the Bureau of Labor Statistics and the annual coal report of Illinois of the State Mining Board. From 1917 to 1994, the reports were published by the Illinois Department of Mines and Minerals (IDMM). The reports list the annual production of each mine in the state, include the location and type of mine, and provide the name, average thickness, and depth of the seam mined.

Four problems were encountered in using the production data: (1) Production is commonly reported for the county where the mine tipple is located, which is not necessarily the county where the coal is mined. (2) Production is commonly reported by mine, not seam. If a mine operates in more than one seam, assumptions must be made as to how to allocate production to each seam. (3) Some underground mining recovers coal classified as surface minable. (4) The production data do not provide information on reserves destroyed or rendered unminable by mining of underlying or overlying seams.

To mitigate some of these problems, special effort was made to obtain unpublished production data by seam and county where the coal was mined in 1994 and 1995. After comparing production data with maps of mined areas, however, it appears that at least two out of 32 mines misreported the county from which they produced. This illustrates the importance of having local knowledge of mining operations when using production figures to calculate depletion.

Depleted underground-minable resources Depleted underground-minable resources consist of the tonnage of underground-minable resources that was originally present in areas that were mined between January 1, 1979, and January 1, 1996. These resources have been extracted by mining or left as pillars within the mines. The tonnage was calculated by combining maps of mines and resources as of 1979, 1994, and 1996 and calculating the tonnage of coal in the area mined since 1979 (fig. 7). Large blocks of unmined coal within mines, coal in barrier pillars between mines, or coal within 200 feet of mine boundaries have not been included in the depleted resources. These areas are, however, considered unminable and excluded from the accessible reserve base. The calculation of depleted underground resources is based entirely on the corrected digital map database compiled for this study. For the most part, the calculation is not influenced by the limitations of precision and accuracy of the base maps or software used for the 1979 study. The accuracy of the calculation is affected to a small extent by the accuracy of the 1979 mine boundaries, which were not drawn or digitized as accurately as the 1994 and 1996 boundaries. Many boundaries (for example, the east boundary of the mine shown in figure 7) are slightly offset. The effect of this offset on the calculation, however, is negligible. 


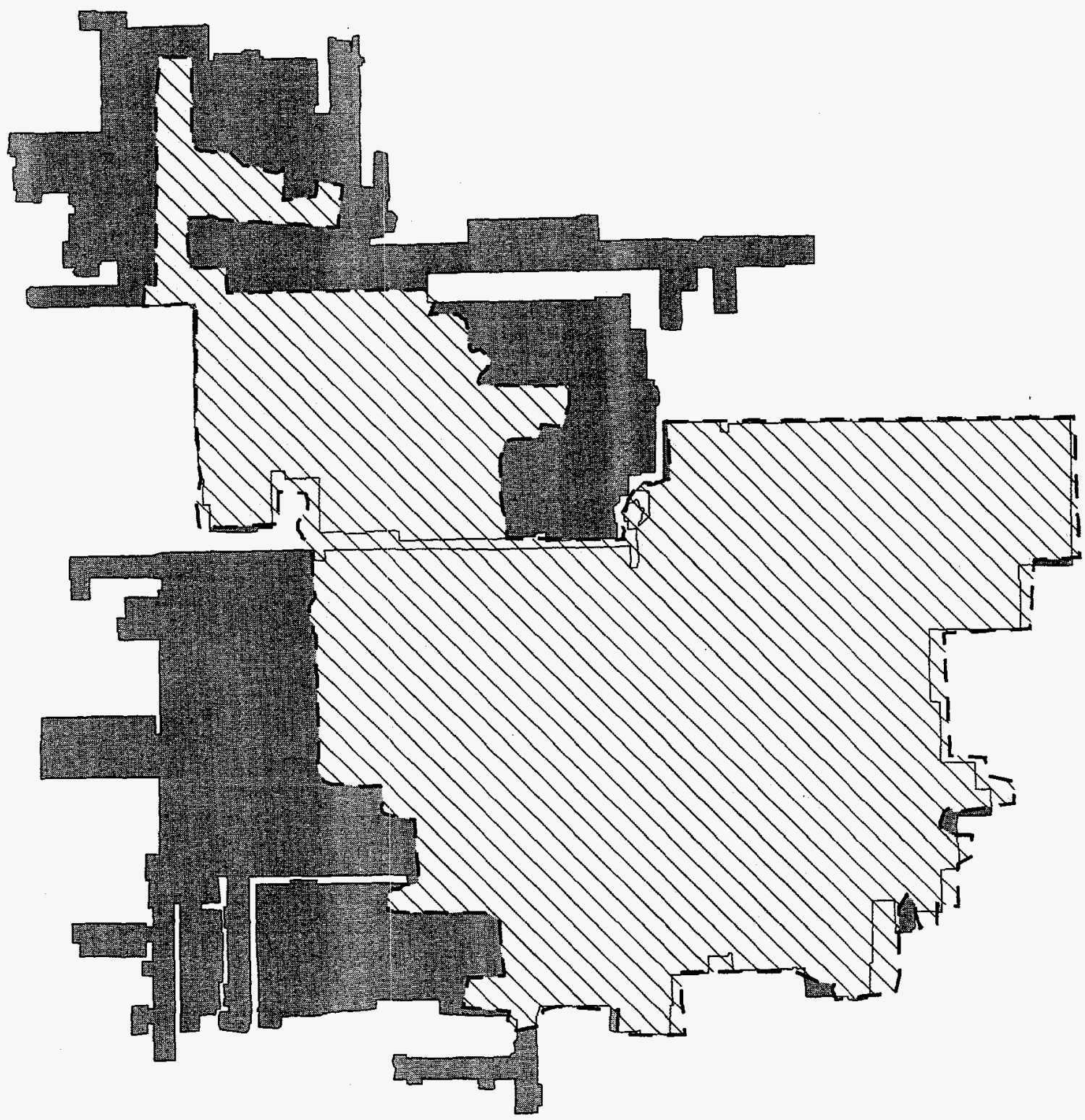

mined areas as of January $1979 \quad-$ boundary of mined area, 1979

mined areas as of January $1996 \longrightarrow$ boundary of mined area, 1996

Figure 7 Examples of changes in mine boundaries of two mines, January 1, 1979, to January 1, 1996.

Cumulative production from surface mines The base year for mapping of surface-minable resources varies from county to county (fig. 8); for example, mapping in southern Illinois included mining to January 1956; mapping in western and northern llinois counties included mining to July 1, 1959; and resources for all other counties were mapped as of January 1 of the year shown. Production from the base year of mapping through 1971 was available from a compilation made by the ISGS in 1973 (DeMaris, unpublished notes). Production of surface coal mines from 1972 to January 1, 1996, was compiled from the annual reports of the IDMM. These two sources were combined to arrive at cumulative production from surface mines in each seam and county from the base year of mapping to 1996. For Saline County, for example, cumulative surface mine production will be reported for each seam from the base year of 1956 to January 1, 1996. 


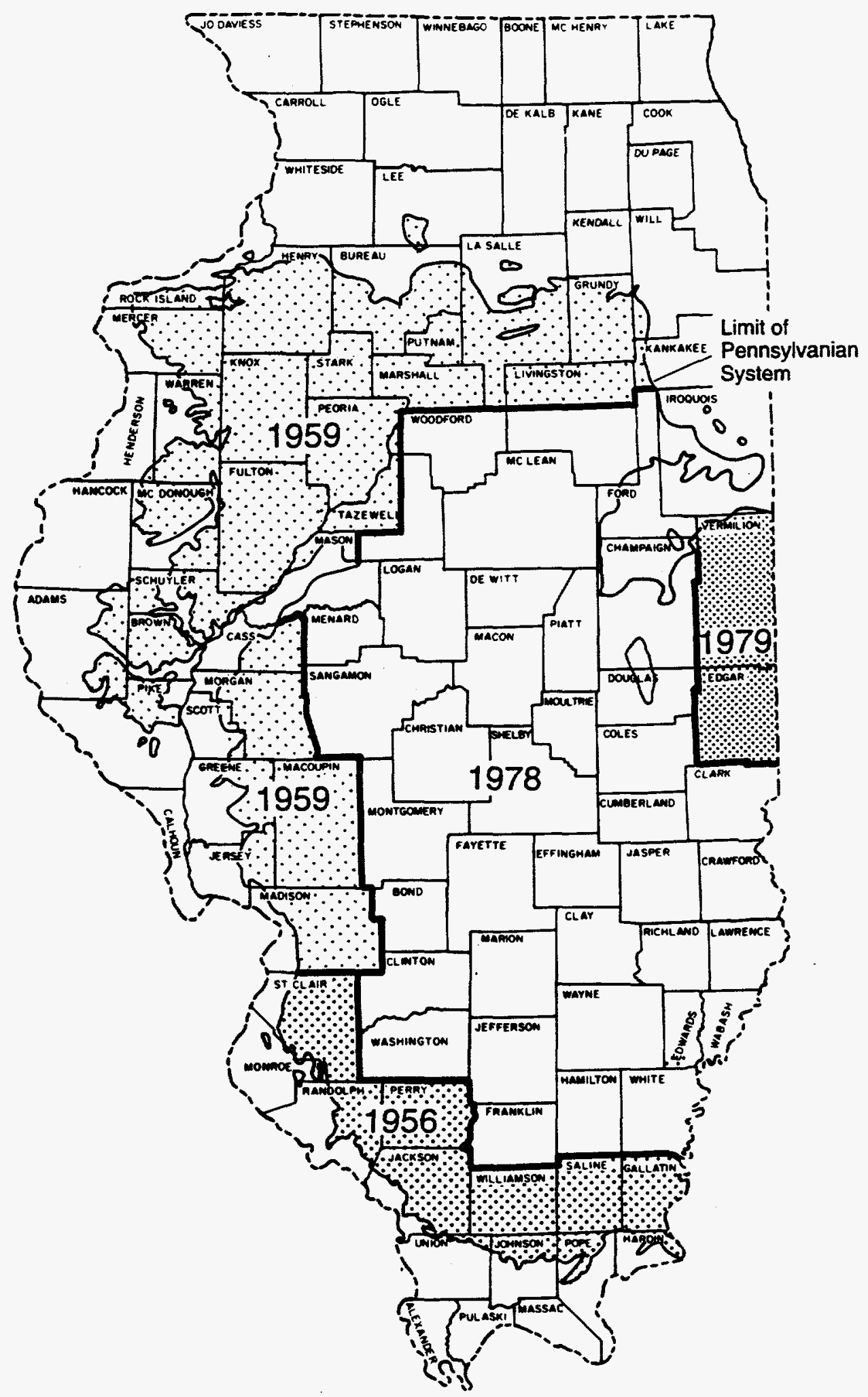

Figure 8 Base year of mapping of surface-minable coal resources. 
Some mines operate pits in two or more counties and process coal at a central tipple. In most cases, the mine's production is listed in the annual coal report under the county where the tipple is located. Records that report production according to the county where the coal was mined are not readily available. The continuous production of large, multicounty operations distorts the apparent cumulative production of certain counties. No attempt was made in this study to reallocate production to the county in which it was mined.

Several mines produce from more than one seam, sometimes as many as five. In most of these cases, the published production is not reported by seam. Allocating production to individual seams requires knowledge of the individual mining operation (including thickness and continuity of the seams), pit locations, and operating goals of the company. A seam may be the main target of a mining operation or merely part of the interburden mined in parts of the mine property. Allocation of production to individual seanns has been based on our best knowledge of each situation. The assumptions used to allocate the production prior to 1971 are documented by DeMaris (unpublished notes, 1973). The assumptions used by this study to allocate production from 1972 to 1994 are listed in appendix 2. Actual totals on production by seam were obtained for 1994 and 1995.

Depleted surface-minable resources The boundaries of mined areas as of January 1, 1996, were merged with the surface-minable resource maps to calculate remaining resources. Cumulative depletion was calculated as the difference between the resources at the date of original mapping (referred to as the base year) and the new (January 1996) resource estimate. For example, depleted surface-minable resources for Saline County is the difference between resources reported for the base year 1956 and those reported as of January $1,1996$.

As explained in the Calculation of Coal Tonnages section above, changes in base maps and technology used (computer vs. planimeter) to calculate areas of coal between the base year and the present study caused increases or decreases of a few percent in reported tonnages (and therefore in cumulative depletion). This effect is most noticeable in counties with limited or no production from surface mines. The apparent depletion in these counties is largely due to these procedural factors rather than to actual mining.

To provide better data on depletion versus reported production, the boundaries of mined areas as of January 1, 1994, were merged with the digital database of coal resources as well. The 1994 and 1996 mine boundaries are comparable in precision and were posted on a common resource map. Therefore, the computation of resource depletion for this period is unaffected by the base map and procedural factors that distort the depletion calculated from base year of mapping to 1996.

\section{Coal Quality Characterizations}

Reserves were allocated to coal quality categories for sulfur, rank, and heat content as specified by EIA's Procedural Guidelines.

Data sources The ISGS has on file more than 4,000 analyses of Illinois coals. Most analyses are of face channel type samples; other sample types include column, bench, drill core, grid, run of plant, run of mine, and various float/sink fractions. The samples were collected and analyzed by ISGS staff, the U.S. Bureau of Mines, or coal companies. Face channel, column, composite bench, and drill core samples (table 6) were used in this study.

Standard face channel samples exclude partings greater than $3 / 8$ inch, whereas column and drill core samples generally do not exclude any material. As a result, face channel samples will have lower ash contents and higher heat content than drill core or column samples taken in the same area. For example, the mean ash content of the Herrin Coal face channel samples was $11.2 \%$, whereas the mean ash content from drill core samples of the Herrin Coal was more than $15 \%$. This difference was taken into consideration in contouring the data (see following sections on sulfur, rank, and heat content). 
The EIA provided copies of data collected by the Federal Energy Regulatory Commission on quality of coal shipped to electric power producers (FERC Form No. 423). These data were used to verify the mapped sulfur contents based on the ISGS analyses.

Quality of coal shipped by mines compared with that of face channel samples Nearly all the coal shipped by Illinois mines has been cleaned. The original concept of the face channel sampling technique (Holmes 1911), in particular the exclusion of mineral partings thicker than $3 / 8$ inch, was intended to simulate the unsophisticated cleaning that prevailed at that time. Modern coal cleaning plants will remove more than just the prominent, visible mineral partings; therefore, in theory, channel samples may not be representative of the quality of the coal that will be produced from the resources in the ground.

In the early 1970s, an ISGS study (Helfinstine et al. 1971 and 1974) sought to determine how representative channel samples are of cleaned Illinois coal. Channel samples were generally found to be a good indicator of shipped coal quality. On the average, channel samples are equivalent to a recovery rate between $70 \%$ and $100 \%$ (averaging about $88 \%$ ) of the combustibles from the full seam.

Current mining technologies generally extract all or most of a coal seam and commonly a small amount of roof and floor rock. To compare the $88 \%$ recovery rate of combustibles cited above with recovery rates from cleaning plants, it is necessary to adjust for partings and out-of-seam dilution that are typically included in the raw coal output from a mine. The ISGS study found that, compared with column samples (channel samples with inclusion of all mineral partings) from the same sites, a $90 \%$ recovery rate of combustibles corresponds to a $70 \%$ to $86 \%$ (averaging $80 \%$ ) recovery of clean coal from the full seam. The mining process may add $5 \%$ out-of-seam dilution, which suggests an overall recovery rate from raw coal of about $65 \%$ to $81 \%$ (averaging $75 \%$ ).

In 1993 , by comparison, llinois mines averaged $69 \%$ clean coal recovery from raw coal; recovery ranged between $51 \%$ and $84 \%$ (for mines producing more than 0.3 million tons per year; IDMM 1993). This lower percentage is not surprising because selection of sites for collecting channel and column samples generally avoids any anomalous seam, roof, or floor conditions that tend to raise the reject. Also, the assumed $90 \%$ recovery of combustibles probably is on the high side for the average of all mines in Illinois. However, for currently active mines for which we have data, the average ash and sulfur contents of shipped coal and of channel samples are nearly identical; face channel samples average only $3 \%$ to $5 \%$ (relative) higher ash and sulfur contents than the corresponding shipped coal. Overall, face channel samples still acceptably represent the quality of cleaned coal that can be produced from a resource.

Quality of coal producible from high- and low- to medium-sulfur reserves Recently the Illinois State Geological Survey (ISGS) collected and comprehensively characterized samples of as-shipped

Table 6 Types of analyses used to assess sulfur, rank, and heat content.

\begin{tabular}{lc}
\hline Sample type & $\begin{array}{c}\text { Number } \\
\text { of analyses }\end{array}$ \\
\hline Face channel & 2,252 \\
Composite face channel & 384 \\
Column & 90 \\
Composite column & 7 \\
Composite bench & 11 \\
Drill core & 948 \\
Composite drill core & 5 \\
\hline
\end{tabular}
coal from all active Illinois mines (Demir et al. 1994). From 1968 to 1974 , the ISGS also collected both run of mine and face channel samples from many active mines and studied their washability characteristics (Helfinstine et al. 1971, Helfinstine et al. 1974). These two sample sets provide insights into the quality of coal that can be produced from the two basic types of coal found in Illinois: high-sulfur and low- to medium-sulfur coal. Figures 9 and 10 show the distribution of sulfur and ash contents as a percentage of the sampled production for the two sampling periods for these two types of coal. For the 1968-1974 study, no analyses of as-shipped coal are available, but instead the 1.6 specific gravity floats can be used as a close approximation. 


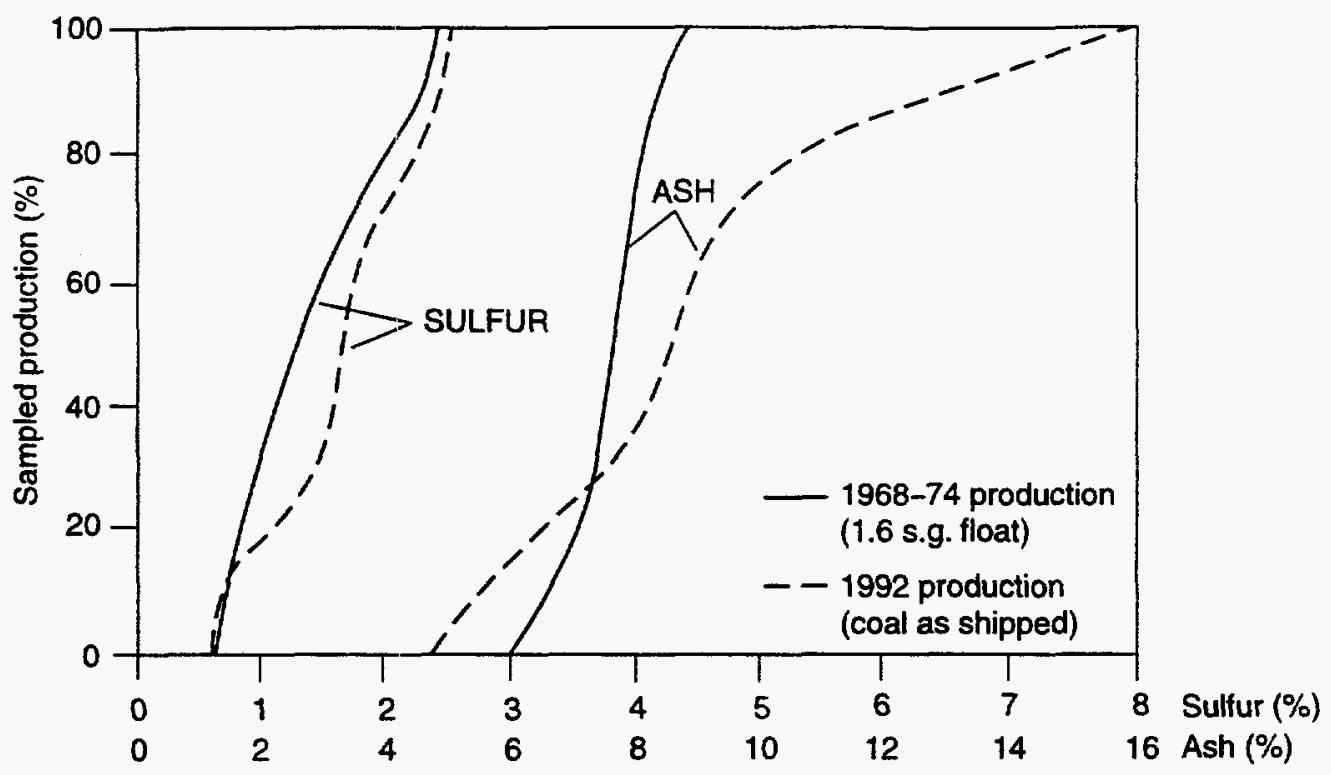

Figure 9 Sulfur and ash contents of low- to medium-sulfur coals.

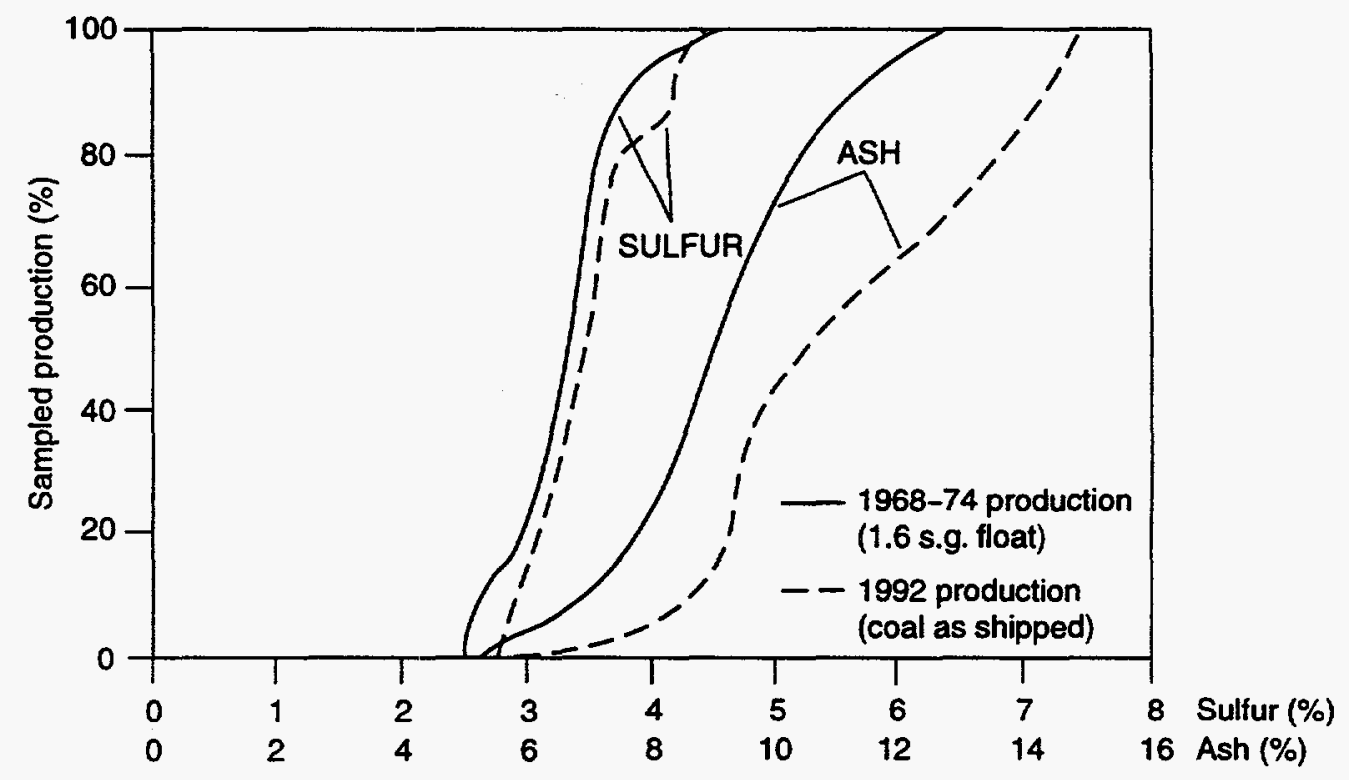

Figure 10 Sulfur and ash contents of high-sulfur coals.

For the low- to medium-sulfur coals, the bottom $20 \%$ of lowest sulfur of sampled production ranges between about $0.7 \%$ and $1.2 \%$ sulfur, and the top $20 \%$ ranges between about $2.1 \%$ and $2.6 \%$ sulfur; the median is about $1.3 \%$ to $1.7 \%$ sulfur. Most of these coals, about $60 \%$ of sampled production, range between $1.0 \%$ and $2.2 \%$ sulfur. The bottom $20 \%$ of lowest ash ranges between about $4.8 \%$ and $7.2 \%$ ash content; most of these coals, about $60 \%$ of sampled production, have ash contents between about $7 \%$ and $10.5 \%$; the median is about $7.7 \%$ to $8.6 \%$ ash. The remaining $20 \%$ of sampled production has higher ash contents, depending on degree of cleaning, up to above $15 \%$.

For the high-sulfur coals, the bottom $20 \%$ of sampled production ranges between about $2.5 \%$ and $3.1 \%$ sulfur; most of the sampled production (about $60 \%$ ) ranges between about $3.1 \%$ and $3.7 \%$ sulfur; the remaining $20 \%$ of production exceeds $3.7 \%$ sulfur, reaching highs of about $4.5 \%$ sulfur. 
The ash content of cleaned Illinois high-sulfur coal generally ranges between a little below $6 \%$ and up to $15 \%$, depending upon the degree of cleaning applied and the characteristics of mined coal. The bottom $20 \%$ of ash content has ash contents between about $5 \%$ and $9.2 \%$; most production (about $60 \%$ ) ranges between about $8 \%$ and $13.6 \%$ percent ash; the median is about $9 \%$ to $10.5 \%$ ash.

The sulfur and ash distribution in these two sample sets is probably a good indication of what can be expected for future production from these two types of coal. Certainly, improved cleaning methods can push the cumulative production curves towards lower sulfur and ash values, but probably not far beyond the 1.6 specific gravity curves for the 1968-1974 sample set.

Sulfur content Sulfur content was mapped as pounds of sulfur per million Btu. The sample basis (as-received, dry, or ash-free) is inconsequential so long as the same basis is used for both sulfur and Btu. Theoretically, the drill cores and column samples could have higher sulfur contents than face channel samples because thick pyrite bands or concretions would be excluded from a face channel; however, this situation is expected to occur mostly in high-sulfur coals (greater than 2.5 pounds sulfur per million Btu). In areas of low to medium sulfur content (the areas contoured for this study), thick pyrite bands are not commonly present. Therefore, the use of drill hole and column samples is not believed to materially alter the allocation of coal within the categories used for this study.

Sulfur content of Illinois coals is related to the environments of deposition and burial associated with the coals. Understanding the geologic features associated with lower-sulfur coal and knowing their distribution aids in mapping these deposits. The approximate extents of areas of low- to mediumsulfur coal for the Danville, Herrin, Springfield, Colchester, and Murphysboro Coals in Illinois have been mapped on the basis of conceptual geologic models (Gluskoter and Simon 1968, Hopkins 1968, Gluskoter and Hopkins 1970, Jacobson 1983, Treworgy and Jacobson 1986). Lower-sulfur deposits of the Danville and Coichester Coals are associated with a silty to sandy facies in the overlying strata. Lower-sulfur deposits of the Herrin, Springfield, and Murphysboro Coals also correspond to areas where the marine black shale and limestone units that normally directly overlie these coals are displaced by silty to sandy non-marine units.

Mapping the sulfur content for each seam began with plotting the sulfur values from analyses along with the geologic boundaries (if any) of sediments normally associated with low-sulfur coals. Contours, hand-drawn by geologists, were based on the plotted analyses, supplemented by geologic interpretation. Contour intervals are those specified in EIA's Procedural Guidelines (table 7). For areas of limited data, it was necessary to confer with coal companies that had explored the areas to learn the general range and pattern of the coal's sulfur content. Because the geologic conditions associated with lower-sulfur coals seem to be relatively rare and the depositional environment at the time of peat deposition normally resulted in high sulfur contents, coals or areas of coals that lacked available analyses and geologic indicators associated with lower-sulfur coal were classified as high sulfur (greater than 2.5 pounds of sulfur per million Btu).

Data available for the Assumption Coal were not adequate to contour the sulfur content, but did indicate a range from 1.7 to 3.2 pounds of sulfur per million Btu. Two-thirds of the tonnage was assigned, on the basis of the number and distribution of data points, to the category of less than 2.5 pounds of sulfur per million Btu; and the remaining one-third was assigned to the category of greater than 2.5 pounds of sulfur per million Btu.

Rank All Illinois coals are high volatile bituminous A, B, or C. Coal rank changes systematically with distribution and depth of the deposit in the coal field (Damberger 1971). Rank was determined by calculating the heat content of samples on a moist, mineral-matter-free basis, according to formulas of ASTM Standard D388 (ASTM 1990). Because this calculation excludes mineral matter, all sample types provide equivalent results.

The Herrin Coal had the widest distribution of analyses of all seams (fig. 11). Analyses of the Herrin served as the primary control for
Table 7 Categories of sulfur content (lbs sulfur/million Btu).

$\leq 0.40$

$0.41-0.60$

$0.61-0.83$

$0.84-1.24$

1.25-1.67

1.68-2.5

$>2.5$ 
mapping trends in rank. Rank group isolines were drawn on the basis of the analyses for each coal as well as on the general trend of the Herrin Coal. In areas of good data control, rank paralleled certain geologic structures: the Shawneetown and Cottage Grove Fault Systems, the Du Quoin Monocline, the La Salle Anticlinal Belt, and the Marshall-Sidell Syncline (figs. 12 and 13). These structures were used to continue the trend of rank isolines across areas of limited control.

Ranks of the other seams were mapped on the basis of available analyses and the regional rank pattern indicated by the Herrin Coal. Coals that are 100 feet above (e.g., the Danville) or below (e.g., the Springfield) the Herrin Coal will have a heat content approximately 100 to 200 Btu per pound lower or higher than the Herrin, respectively (Damberger 1971). The data for the two coals stratigraphically above the Herrin, the Danville and Jamestown, were sparse and were insufficient to calculate a significant change in rank from the Herrin Coal, so the same rank lines were used for all three coals. The data for the Springfield Coal suggest a B/C rank group boundary that corresponds to the Herrin Coal along the east and west sides of the basin, but extends farther northward in the central part of the basin (fig. 13). The rank of the Seelyville (for which there are considerable resources, but few analyses) is based on analyses of the overlying Colchester Coal and a calculated increase in Btu per pound, based on depth of the Seelyville below the Herrin. Other coals were of limited extent and were assigned rank based on available analyses.

Heat content The analyses of the coals were used to map their heat content in million Btu per ton on an as-received basis, according to the categories specified in EIA's Procedural Guidelines (table 8). Because ash content affects the heat content, an adjustment is needed to compensate for the higher ash values of drill holes.

The mean ash content for all face channels of Herrin Coal $(1,436$ samples) is $11.2 \%$, with a standard deviation of $2 \%$. Aside from increases in ash content near channels contemporaneous with peat deposition, no pattern of ash distribution has been observed. The mean ash value was used to compute a normalized heat content for the drill core analyses. At this mean ash value, the 23-and 25-million-Btuper-ton contours correspond closely to the $B / C$ and $A / B$ rank group boundaries, respectively. Given the distribution of available data, the same isolines were judged, for purposes of this study, to be suitable boundaries for both rank and heat content per ton.

\section{Coal Accessibility Adjustments}

The accessible reserve base is defined by the EIA (Richard Bonskowski, personal communication, September 1995) as the portion of the DRB that can be mined at present, when local or regional mining practice and technologies, physical or geologic conditions, and societal constraints are taken into account. Factors restricting accessibility are determined on a state-by-state basis and may include land use restrictions (towns, cemeteries, highways, railroads, oil and gas wells) and technological, geologic, and regulatory constraints (coal depth and thickness, geologic conditions, proximity to another coal seam or mine, or barrier coal left between mines), all of which may change with time. The EIA has expanded its original concept of accessibility to include, for new resource studies and revisions, the limiting effects of certain technological and geologic conditions. In the past, such adjustments were made in the resource database by the field investigator or within the DRB derivation, and were difficult to reassess. The EIA is taking advantage of the more detailed assessment capabilities of computerized resource mapping systems to enhance the comparability of coal accessibility and the USGS concept of coal availability (as presented below). The expanded definition has been incorporated into the Illinois study.

The USGS supports state geological surveys in their detailed investigations of selected small but representative sample areas (7.5-minute quadrangles) in order to identify and quantify factors that limit the availability of coal for future development (Eggleston et al. 1990). These coal availability studies define as "available" those resources not restricted by land use, geologic, or technological parameters.
Table 8 Categories of heat content (million Btu/short ton).

226

25-25.99

23-24.99

20-22.99

15-19.99 


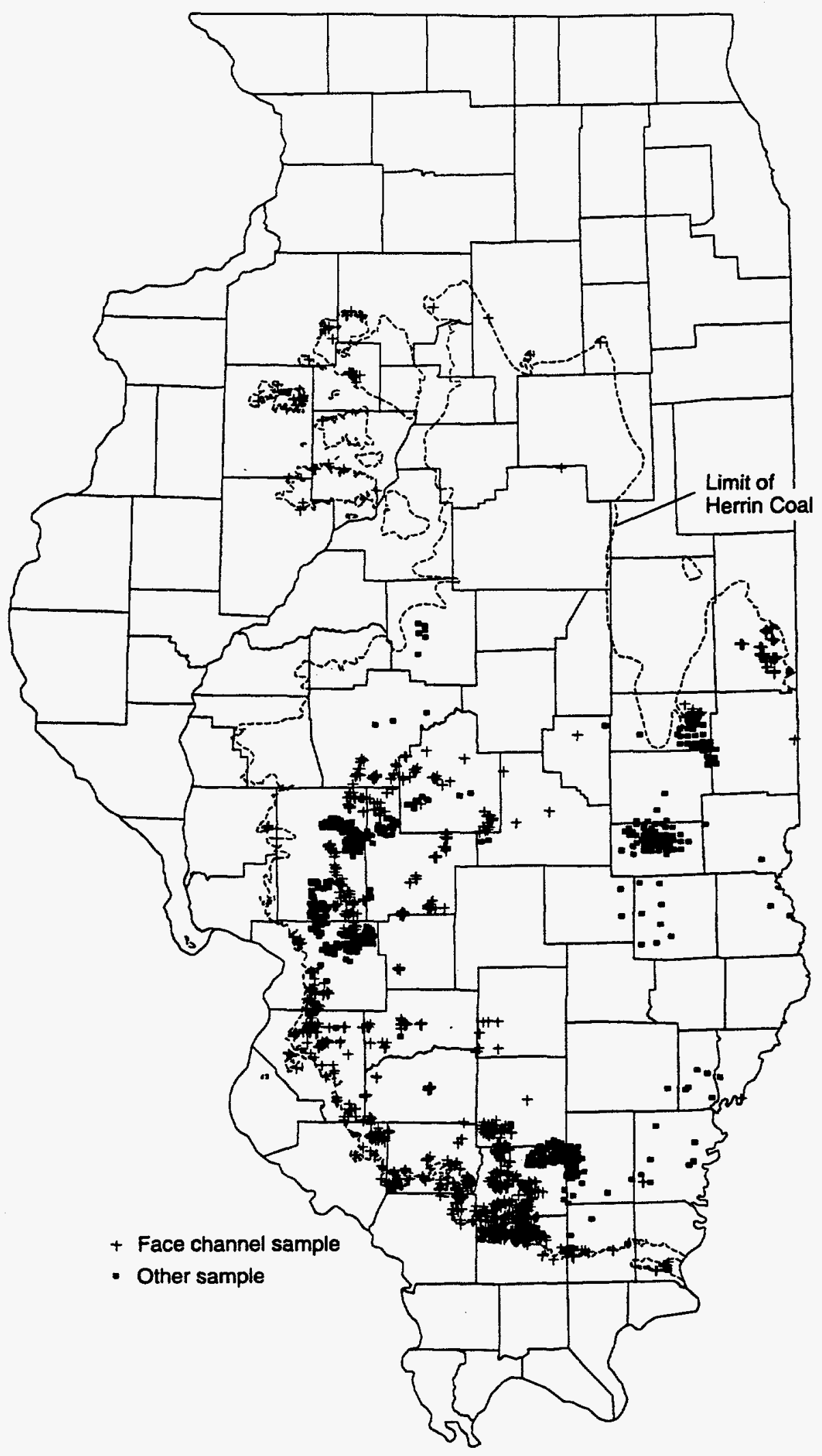

Figure 11 Locations of Herrin Coal samples analyzed to determine rank, sulfur content, and heat content. 


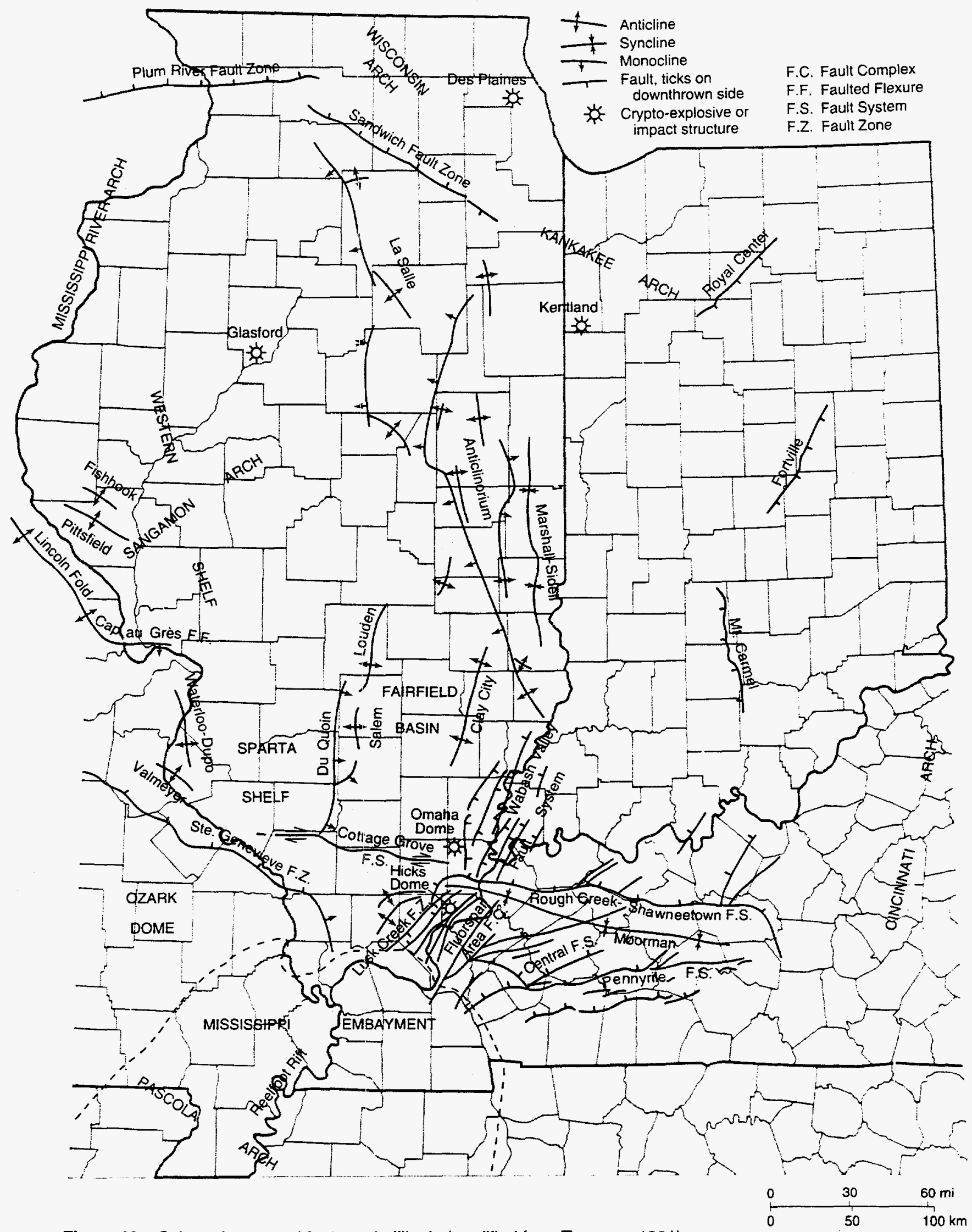

Figure 12 Selected structural features in Illinois (modified from Treworgy 1981). 


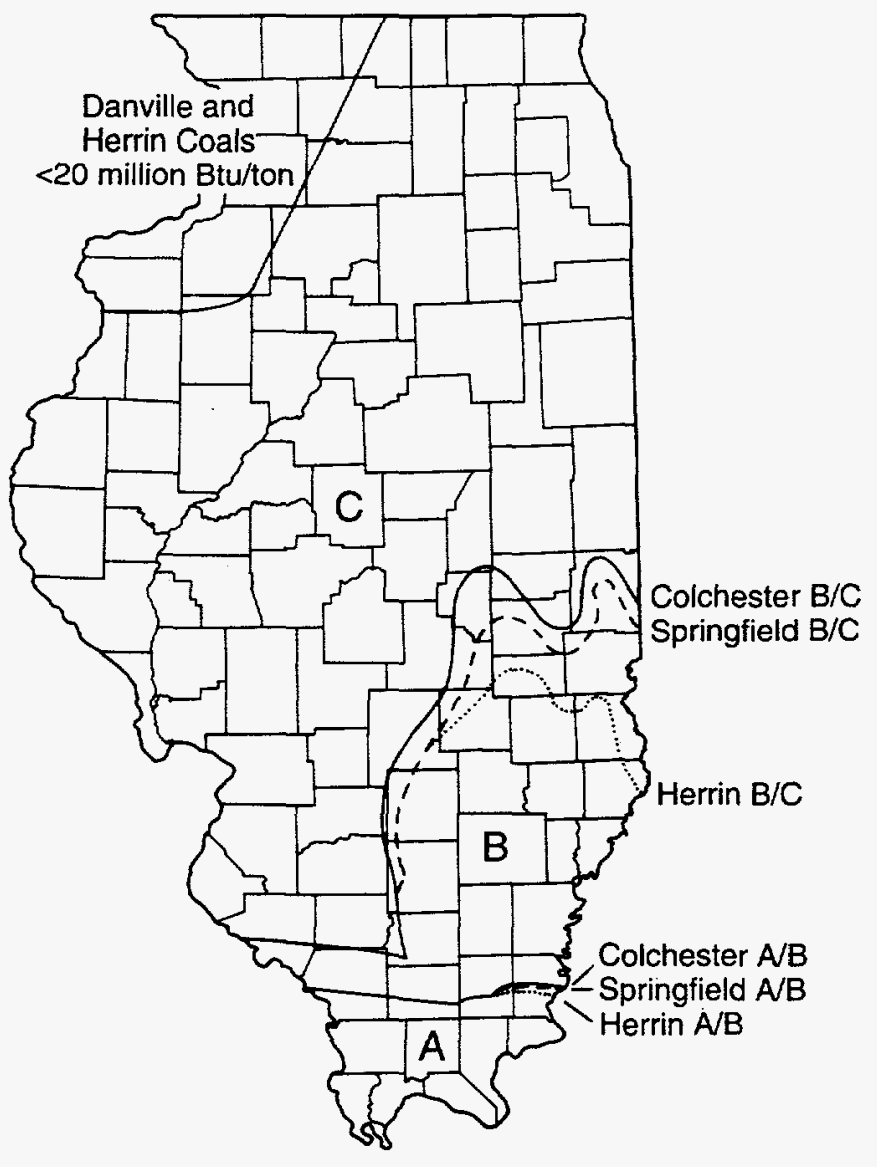

Figure 13 Rank of selected high volatile coals in Illinois. $A=$ high volatile $A$ bituminous rank; $B=$ high volatile $B$ bituminous rank; $\mathrm{C}=$ high volatile $\mathrm{C}$ bituminous rank.
Atthough available resources, as defined by the USGS, are currently too limited a sampling to support a national database, they do constitute an important source of information for EIA coal supply projections. While maintaining the integrity of the DRB as a nationally consistent database, the EIA is working to minimize the differences between the concepts of available and accessible resources. The accessible reserve base includes essentially the portion of available resources that would meet DRB criteria. For new resource updates, the EIA is coordinating data on coal accessibility and coal availability to the extent feasible.

The ISGS is in the fourth year of a multiyear study supported by the USGS to assess the availability of coal for mining (Treworgy et al. 1994, Treworgy et al. 1995, Jacobson et al. 1996, Treworgy et al. 1996a,b). At this point in the project, eight quadrangles have been evaluated, about $30 \%$ of the number needed to reliably assess the availability of all the resources in the state (fig. 14).

The amount of coal available for mining in the sample areas has ranged from $18 \%$ to $76 \%$ of the original resources (fig. 15). Technical factors such as thickness of the coal and overlying

bedrock, roof and floor conditions, faults, and size of the mining block account for most of the restrictions on coal availability. Land use restricts from less than $1 \%$ to $22 \%$ of the resources in the quadrangles studied.

Although it is too early to apply most of the initial findings of this coal availability study, some preliminary observations have been incorporated into this estimate of accessible reserves. It is anticipated that the final findings of this study will significantly alter the accessible reserve base. The factors considered for estimating the accessible reserve base are listed in table 9 .

Prime farm land Almost $60 \%$ of the 36 million acres of land in Illinois is classified as prime farm land. The percentage of surface-minable resources underlying prime farm land is not available. In 1978 the ISGS identified 6 billion tons of surface-minable reserves with the highest potential for development. Using the percentage of prime farm land in each county, the IDMM estimated that $58 \%$ of these reserves underlie prime farm land and that this represents $2.5 \%$ of the prime farm land in the state (IDMM 1993).

EIA's current estimate of accessible coal in Illinois excludes surface-minable reserves in areas of prime farm land. Illinois' surface mine regulations do not preclude the mining of prime farm land, and 


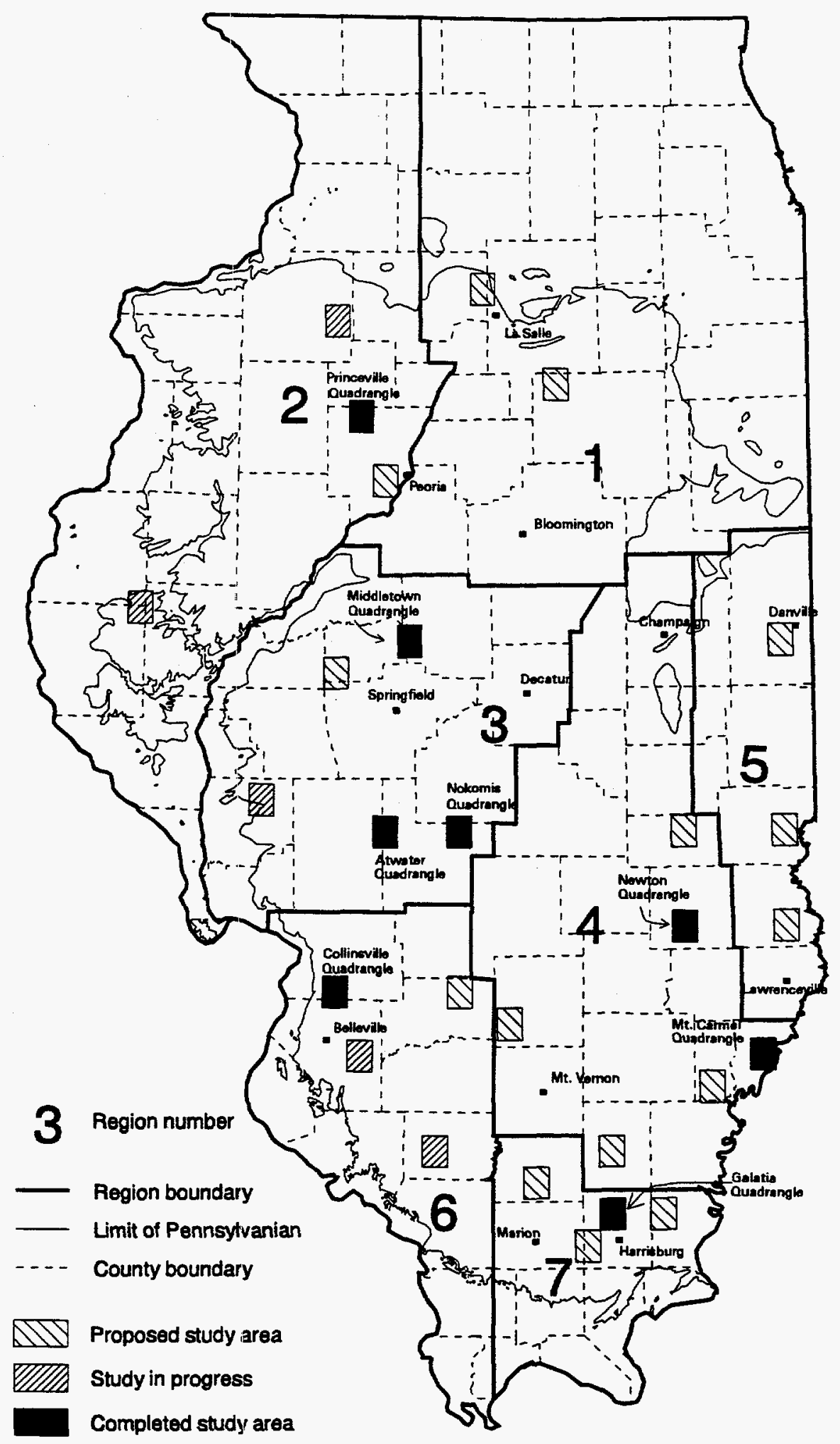

Figure 14 Quadrangles selected for coal availability studies. 


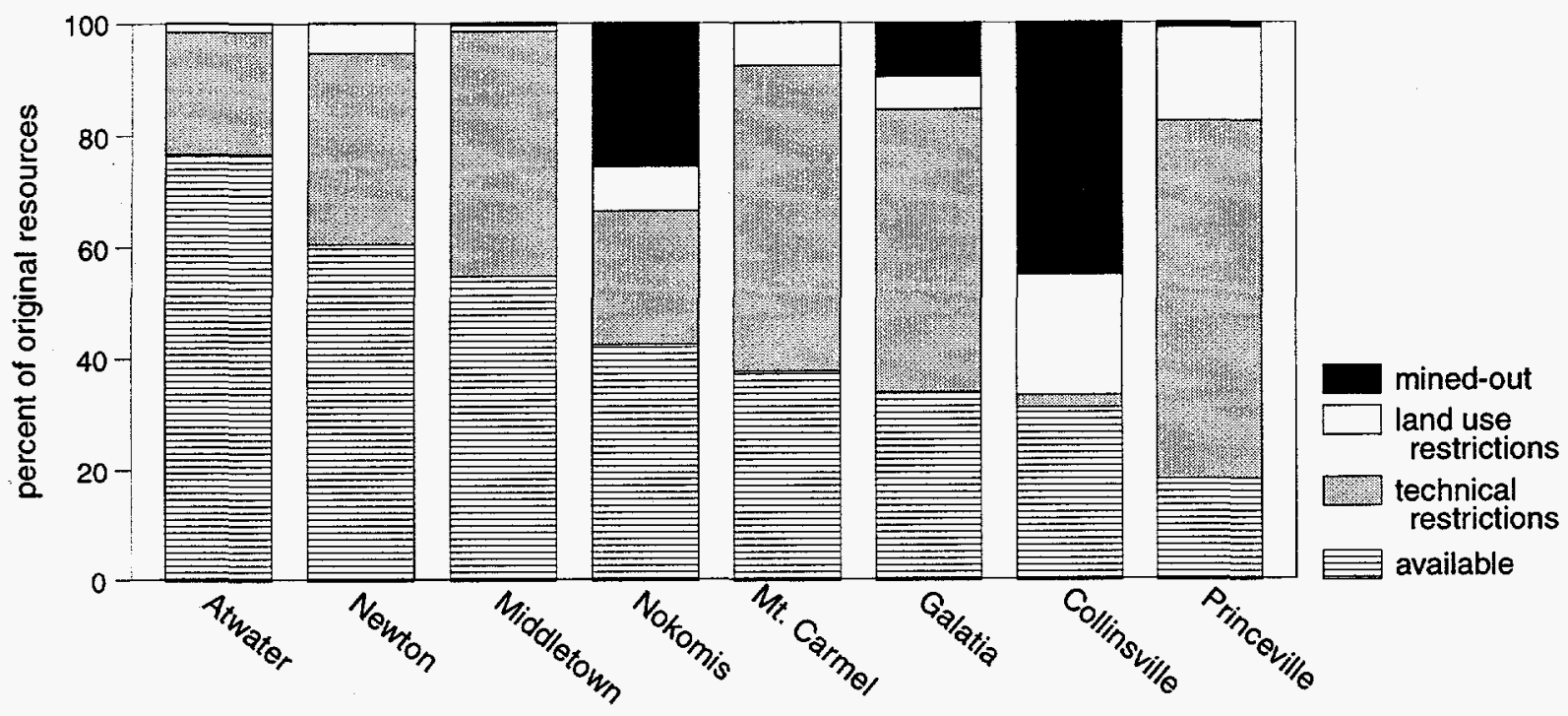

Figure 15 Availability of coal resources in eight quadrangles in Illinois.

Table 9 Factors considered and applied to the demonstrated reserve base to estimate the accessible reserve base.

\begin{tabular}{|c|c|c|}
\hline Factor considered & Applied? & Remarks \\
\hline \multicolumn{3}{|l|}{ Technical } \\
\hline Prime farm land & No & There is no evidence that prime farm land restricts access. \\
\hline Areas densely drilled for oil & No & $\begin{array}{l}\text { The presence of wells does not raise costs enough to restrict } \\
\text { access. }\end{array}$ \\
\hline $\begin{array}{l}\text { Barrier pillars and small } \\
\text { blocks between mines }\end{array}$ & Yes & $\begin{array}{l}\text { Tonnage of existing blocks and barriers was calculated } \\
\text { from maps. Tonnage of blocks and barriers created by } \\
\text { future mining was estimated to be } 15 \% \text { of reserves } \\
\text { otherwise accessible. }\end{array}$ \\
\hline Thin coal & Yes & Underground-minable reserves $<42$ inches thick excluded. \\
\hline Land Use & & $\begin{array}{l}\text { The tonnage of underground-minable reserves restricted } \\
\text { by all land use categories was estimated from previous } \\
\text { mapping; } 6 \% \text { of all surface-minable reserves was } \\
\text { assumed to be inaccessible because of land use. }\end{array}$ \\
\hline Interstate highways & Yes & \\
\hline Towns & Yes & \\
\hline Cemeteries & Yes & \\
\hline Public lands & Yes & \\
\hline
\end{tabular}

the coal availability studies do not indicate that operators consider areas of prime farm land to be unminable. Currently, surface mines in the state are mining and successfully reclaiming areas of prime farm land. In recent interviews with four surface mine operators conducted for a coal availability study involving prime farm land, none of the operators considered prime farm land to limit accessibility of the reserves. For these reasons, prime farm land was not used as a factor in estimating the accessible reserve base.

Areas densely drilled for oil Since Cady (1952), the ISGS has excluded areas densely drilled for oil from its calculation of coal reserves. Coal mining experts interviewed by Treworgy and Bargh (1982) confirmed this restriction, and the amount of coal excluded ( 9.6 billion tons) was documented for the first time. In theory, safety considerations prevented mining coal in such areas. Our recent coal availability studies found that mining companies no longer regard closely spaced oil wells as an absolute barrier to mining. Although regulations of the Mine Safety and Health Administration (MSHA) require 
that a barrier pillar be left around wells, experienced mining companies have been allowed to reduce the size of the pillar. In many cases of abandoned wells, it has been feasible for the mining company to plug the well to MSHA specifications and mine through it. The decrease in the amount of coal recovered or the increase in the cost of mining is not severe enough to consider the reserves inaccessible.

Underground-minable coal less than $\mathbf{4 2}$ inches thick The eight quadrangles studied to date for coal availability in Illinois contain about $3 \%$ of the underground-minable resources in the state and include all the major seams. In assessing the availability of these resources, seven of the eight companies operating major underground mines in the state were interviewed. All seven companies identified coal thinner than 48 inches as too thin to mine economically by underground methods. Because the state lacks natural outcrops of coal, most underground mines require extensive exploratory and developmental drilling to obtain data for mine planning and permitting, and for the construction of slopes and shafts for the movement of air, men, materials, and coal. To justify these expensive and time-consuming pre-mining investments, mines must produce large tonnages of low-cost coal. Mining in thin seams requires more acreage, and the mining costs are higher. For these reasons, underground-minable reserves from thin seams have been excluded from the accessible reserve base. Because the 42-inch isopach was mapped for all reserves (the 48-inch isopach was mapped for only a portion of the reserves), 42 inches is used as the minimum thickness for accessible reserves. Reserves that were mapped as "average 42 inches" (which amounted to less than 350 million tons) were excluded from accessible reserves because it was assumed that at least half the deposit was less than 42 inches thick and that the coal greater than 42 inches is in blocks too small or irregular to mine.

Coal rendered inaccessible by mining A significant portion of inaccessible reserves consists of blocks of coal left as barrier pillars (Illinois law requires 200 feet between mines) or simply left out of the mining plan because of the geometry of the mine plan, early abandonment of a mine, inability to obtain land ownership or mineral rights, or unfavorable geology. Once surrounded by abandoned mines, these blocks are too small or irregular to be minable.

The approximate area of coal rendered inaccessible by mining was calculated by creating a 200-foot buffer around each mine (fig. 16). The buffer areas for each seam were examined and adjusted to include additional areas of coal considered to be unminable because of the small size of the mining area, convoluted geometry, or proximity to mined areas. The tonnage of coal in the adjusted buffer areas was calculated and excluded from the accessible reserve base.

Additional blocks will become inaccessible as mining continues. The amount of coal rendered inaccessible depends upon many variables. Studies conducted by the U.S. Bureau of Mines in selected quadrangles of West Virginia, Kentucky, and Illinois found that, even with optimal mine layouts, from $2 \%$ to $12 \%$ of the original resources will be left as barrier pillars (U.S. Bureau of Mines 1995). In reality, an optimal mine layout never occurs. Geologic conditions, availability of land and mineral rights, market conditions, and the desire of companies to maximize profits result in less than optimal placement of mines. This study found that, on a county-by-county basis, the amount of inaccessible coal ranged from $6 \%$ to more than $40 \%$ of the original resources in mined areas. On a statewide basis, the amount of inaccessible coal was roughly $20 \%$ of the original resources in mined areas. Some of this coal may have been left because of surface features, which are accounted for separately; thus it was assumed that $15 \%$ of the coal otherwise qualified for the accessible reserve base will be rendered inaccessible by future mining.

Other technical factors Other technical factors that restrict the accessibility of reserves include insufficient thickness of the bedrock overburden, insufficient thickness or strength of interburden between seams, other unfavorable roof or floor conditions, and partings in the coal seam. These factors are not understood well enough at this time to use them to adjust the accessible reserve base. At the completion of Illinois' coal availability assessment, the accessible reserve base should be adjusted to include as many of these factors as practical. 


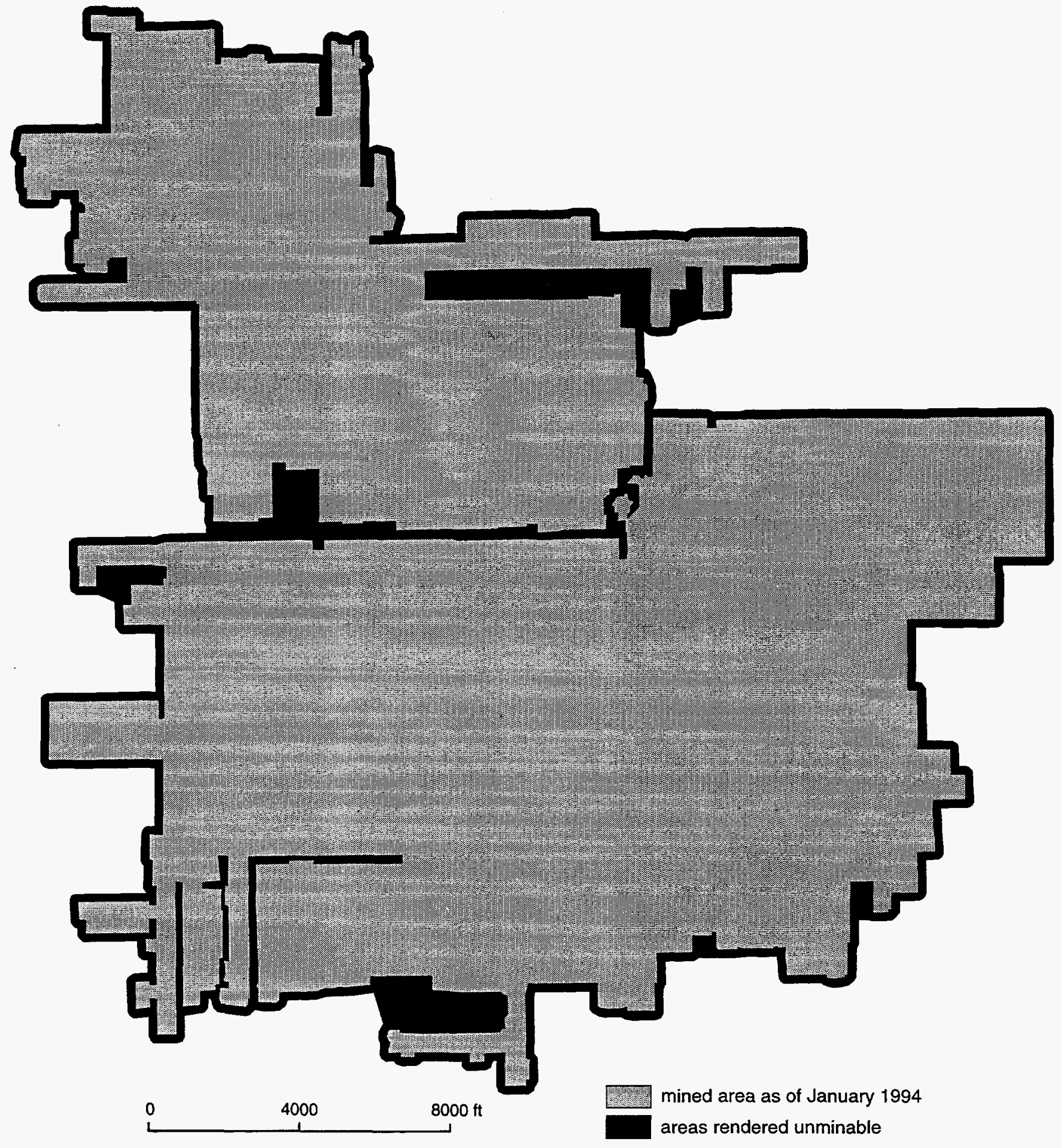

Figure 16 Typical areas of unminable coal between and adjacent to two mines.

Land use Earlier investigations identified land uses such as interstate highways, railroads, cemeteries, towns, and public lands as factors that limit the accessibility of coal (Treworgy et al. 1978 , Treworgy and Bargh 1982). Current coal availability studies indicate that some refinements are needed in assessing these factors. For example, early results indicate that surface mining can 
be conducted closer to towns in southern Illinois than in other parts of the state. County and township roads are serious obstacles to surface mining in some counties, but not in others. Additional quadrangle studies will help to define these factors and how they should be applied to the accessible reserve base.

The tonnage of underground-minable coal rendered inaccessible by surface features was mapped and calculated in the 1979 estimate of resources (Treworgy and Bargh 1982). The percentage of accessible coal varied from county to county; rural counties generally have $96 \%$ to $98 \%$ accessible, and counties with large urban areas have $78 \%$ to $92 \%$ accessible (appendix 3 ). The percentage of accessible coal for each seam in each county was applied to the underground-minable DRB (minus coal rendered inaccessible by mining) to obtain the underground-minable portion of the accessible reserve base.

Although the accessibility of surface-minable reserves has been considered in a previous study (Treworgy et al. 1978), changes in mining practice and findings from coal availability studies indicate that major changes in criteria used to evaluate accessibility are needed. For this preliminary assessment, a $94 \%$ rate of accessibility was applied in all counties to the new surface-minable DRB. This figure was chosen because it is the statewide average for the underground-minable reserves and it falls in the middle of the range measured for the surface-minable resources in the quadrangles studied to date for coal availability. When more data are available, the accessibility rate for surface-minable coal is expected to vary widely from county to county.

\section{Recovery Rates}

The EIA provided data on reported recovery rates from individual mines in Illinois for 1991 to 1993. These data were compared with regional recovery rates calculated from depletion (measured from resource maps) and production data (compiled from IDMM reports).

Underground mining Recovery rates for underground reserves were calculated by comparing depletion of underground resources (as indicated by maps of original resources and mined areas) with reported production. For those counties where a valid comparison could be made (representing $66 \%$ of the production and $72 \%$ of the depletion), recovery rates for 1979 to 1996 ranged from $36 \%$ to $58 \%$ on a county and seam basis and averaged $47 \%$ for all seams and counties combined (table 10). This rate compares favorably with ElA data for 1991 through 1993, which show a weighted average recovery rate of $50 \%$ for all underground mines. The higher rate

Table 10 Depletion, production, and calculated recovery rate of underground-minable resources in selected counties from January 1,1979 , to January 1,1996 , in millions of short tons.

\begin{tabular}{llccc}
\hline County & Coal & Depletion & Production & $\begin{array}{c}\text { In-mine } \\
\text { recovery } \\
\text { in percent }\end{array}$ \\
\hline $\begin{array}{llrl}\text { Christian, Montgomery, } \\
\quad \text { and Sangamon }\end{array}$ & Herrin & 142 & 69 & 49 \\
Clinton & Herrin & 125 & 45 & 36 \\
Douglas & Herrin & 42 & 18 & 43 \\
Franklin & Herrin & 192 & 112 & $58^{\star}$ \\
Gallatin & Springtield & 40 & $16^{\star \star}$ & 39 \\
Hamilton & Springfield & 14 & 6 & 44 \\
Jefferson & Herrin & 133 & 68 & 51 \\
Logan and Sangamon & Springlield & 40 & 15 & 38 \\
Macoupin & Herrin & 146 & 61 & 42 \\
Washington & Herrin & 47 & 25 & 53 \\
White & Herrin & 36 & 16 & 44 \\
TOTAL & & 957 & 451 & 47 \\
\hline
\end{tabular}

* A significant portion of the production during this period came from longwall mines, hence the higher recovery rate.

** Excludes production of underground mines from surface-minable resources. 
reported by the EIA probably reflects the increased use of longwall equipment over this period ( $32 \%$ of production in 1993 versus $15 \%$ in 1979). Based on these statistics, a factor of $50 \%$ was used to calculate remaining recoverable underground-minable reserves.

Some consideration was given to using a higher recovery rate in counties where longwall mining is being practiced. However, the EIA's data did not show a consistent relationship between mines operating longwalls and higher recovery rates. This probably reflects the influence of other factors such as geology, amount of coal preparation, and development stage of individual mines on recovery rates.

A valid comparison between depletion and production could not be made in several counties because reported production included production from outside the county, underground-minable reserves were depleted by surface mining, or production was too small to measure depletion at the scale of mapping (table 11).

Surface mining Data provided by the EIA for individual surface mines for 1991 to 1993 showed recovery rates from $60 \%$ to $90 \%$, with a weighted average of $75 \%$. These figures compare favorably with recovery rates for selected counties, as calculated from cumulative depletion (from base year of mapping to January 1996) of surface-minable resources and reported cumulative production from surface mines (table 12).

Both EIA data and ISGS depletion data from base year of mapping to 1996 suggest that recovery rates are lower for thinner seams (e.g., the Colchester Coal) or seams with many impurities (e.g., the Herrin Coal in Fulton and Peoria Counties). The Herrin Coal in northwestern lllinois commonly contains impurities in the form of a widespread parting known as the "blue band" and prevalent occurrences of "white top" and clay dikes (Smith and Berggren 1963, Damberger 1970).

Table 11 Depletion and production of underground-minable resources in selected counties from January 1,1979 , to January 1,1996 , in millions of short tons.

\begin{tabular}{|c|c|c|c|c|}
\hline County & Coal & Depletion & Production & Remarks \\
\hline Coles & Herrin & 0 & 0.01 & $\begin{array}{l}\text { Area mined too small to measure at scale of } \\
\text { mapping }\end{array}$ \\
\hline Perry & Herrin & 38 & 25 & $\begin{array}{l}\text { Considerable production from surface-minable } \\
\text { reserves }\end{array}$ \\
\hline Randolph & Herrin & 74 & 63 & $\begin{array}{l}\text { Considerable production from surface-minable } \\
\text { reserves }\end{array}$ \\
\hline St. Clair & Herrin & 4 & 14 & Most production from surface-minable reserves \\
\hline Saline & Herrin & 61 & 31 & $\begin{array}{l}\text { Some production from surface-minable } \\
\text { reserves, and some from Williamson County }\end{array}$ \\
\hline Saline & Springfield & 78 & 39 & $\begin{array}{l}\text { Some production from surface-minable } \\
\text { reserves, and some from Williamson County }\end{array}$ \\
\hline Sangamon & Springfield & 7 & 2 & Production reported under Logan County \\
\hline Vermilion & Danville & 0 & 0.2 & $\begin{array}{l}\text { Area mined too small to measure at scale of } \\
\text { mapping }\end{array}$ \\
\hline Vermilion & Herrin & 0 & 0.3 & All production from surface-minable reserves \\
\hline Wabash & Springfield & 74 & 46 & $\begin{array}{l}\text { About one-third of this production is from } \\
\text { Indiana }\end{array}$ \\
\hline Williamson & Herrin & 28 & 9 & $\begin{array}{l}\text { Some production from surface-minable } \\
\text { reserves, and some tonnage reported } \\
\text { under Franklin and Saline Counties }\end{array}$ \\
\hline Williamson & Springfield & 11 & 1 & $\begin{array}{l}\text { Some production from surface-minable } \\
\text { reserves, and most production reported } \\
\text { under Saline County }\end{array}$ \\
\hline TOTAL & & 375 & 231 & \\
\hline
\end{tabular}


Table 12 Depletion, reported production, and calculated recovery rates for surface-minable resources from base year to January 1,1996 , in millions of short tons.

\begin{tabular}{|c|c|c|c|c|c|c|}
\hline County & Seam & $\begin{array}{c}\text { Resources } \\
\text { as of } \\
\text { base year }\end{array}$ & $\begin{array}{l}\text { Current } \\
\text { resources }\end{array}$ & $\begin{array}{c}\text { Inferred } \\
\text { depletion }\end{array}$ & $\begin{array}{l}\text { Reported } \\
\text { surface-mine } \\
\text { production }\end{array}$ & $\begin{array}{c}\text { Recovery } \\
\text { rate }^{*}\end{array}$ \\
\hline $\begin{array}{l}\text { Fulton } \\
\text { Fulton } \\
\text { Knox } \\
\text { Peoria } \\
\text { Peoria } \\
\text { Perry } \\
\text { Randolph } \\
\text { Randolph } \\
\text { St. Clair } \\
\text { Schuyler } \\
\text { Will } \\
\text { TOTAL }\end{array}$ & $\begin{array}{l}\text { Springfield } \\
\text { Colchester } \\
\text { Herrin } \\
\text { Herrin } \\
\text { Colchester } \\
\text { Herrin } \\
\text { Herrin } \\
\text { Springfield } \\
\text { Herrin } \\
\text { Springfield } \\
\text { Colchester }\end{array}$ & $\begin{array}{r}702 \\
1,105 \\
257 \\
1,058 \\
108 \\
897 \\
279 \\
176 \\
1,241 \\
113 \\
22 .\end{array}$ & $\begin{array}{r}576 \\
1,070 \\
213 \\
1,031 \\
101 \\
614 \\
181 \\
155 \\
1,091 \\
105 \\
14\end{array}$ & $\begin{array}{r}126 \\
35 \\
44 \\
27 \\
7 \\
282 \\
98 \\
21 \\
150 \\
8 \\
8 \\
806\end{array}$ & $\begin{array}{c}101 \\
20 \\
29 \\
19 \\
6.7 \\
242 \\
68 \\
19 \\
117 \\
4 \\
6 \\
632\end{array}$ & $\begin{array}{l}80 \\
57 \\
66 \\
70 \\
96 \\
86(\mathrm{ug}) \\
69(\mathrm{ug})^{\star \star} \\
90 \\
78(\mathrm{ug})^{\star *} \\
50 \\
80 \\
78\end{array}$ \\
\hline
\end{tabular}

Based on these data, a recovery rate of $70 \%$ was used in this study to calculate recoverable surface-minable reserves for seams less than 48 inches thick and the Herrin Coal in northwestern Illinois. A recovery rate of $85 \%$ was used for all other surface-minable reserves. A valid comparison between depletion and production could not be made in several counties where reported production included production from outside the county, where reserves were destroyed by mining of lower seams, or where significant quantities of surface-minable reserves were mined by underground mines (table 13). Comparisons also could not be made in counties where reserves have been partially revised since the base year of mapping or where production from surface mines is small and the amount of depletion is masked by changes in the base map.

\section{RESULTS \\ Demonstrated Reserve Base}

The new demonstrated reserve base (DRB) for Illinois as of January 1, 1996, is 105 billion short tons (table 14). The previous estimate was 78 billion short tons. The new estimate arises from revised resource calculations based on recent mapping in a number of counties as well as significant adjustments for depletion due to past mining. Areas of coal reserves densely drilled for oil or gas exploration, excluded from the earlier DRB estimate, account for about 3 billion tons of the increase.

The new estimates incorporate analyses of available sulfur, heat content, and rank group data appropriate for characterizing the remaining coal resources in Illinois. Coal-quality data were examined in conjunction with coal resource mapping. Analyses of samples from exploration drill holes, channel samples from mines and outcrops, and geologic trends were compiled and mapped to allocate coal resource quantities to ranges of sulfur content and heat content. The new allocations place almost $1 \%$ of the DRB of Illinois in the two lowest sulfur categories ( 920 million tons), compared with none in the previous allocation used by the EIA. The new allocations place $89 \%$ of the reserve base in the highest sulfur category, compared with $69 \%$ in the earlier allocation.

Table 14 summarizes the new estimate of the DRB by mining method, sulfur content, and heat content. A complete listing of the DRB by county, seam, depth, heat content, and sulfur content is contained in appendix 4.

\section{Accessible Reserve Base}

The new estimate of the accessible reserve base is 70 billion tons, compared with the previous estimate of 56 billion tons (table 15). Unlike the previous estimate, the present compilation does not exclude surface-minable coal under prime farm land. However, underground-minable coal 
Table 13 Mapped depletion and reported production of surface-minable resources from base year to January 1 , 1996. Unless otherwise indicated under Remarks, production was statistically too small, relative to resources, to calculate a recovery rate. Tonnages are in millions of short tons.

\begin{tabular}{|c|c|c|c|c|c|c|}
\hline County & Seam & $\begin{array}{l}\text { Resources } \\
\text { as of } \\
\text { base year }\end{array}$ & $\begin{array}{l}\text { Current } \\
\text { resources }\end{array}$ & $\begin{array}{l}\text { Inferred } \\
\text { depletion }\end{array}$ & $\begin{array}{l}\text { Reported } \\
\text { surface-mine } \\
\text { production }\end{array}$ & Remarks* \\
\hline Adams & Colchester & 619 & 616 & 3 & 0.3 & \\
\hline Brown & Colchester & 386 & 363 & 23 & 0.4 & $\begin{array}{l}\text { Some production reported } \\
\text { under Schuyler County }\end{array}$ \\
\hline Bureau & Herrin & 262 & 273 & & 2 & \\
\hline Edgar & Danville & 150 & 151 & & 1 & \\
\hline Fulton & Danville & 59 & 57 & 2 & 0 & $\begin{array}{l}\text { Destroyed by mining of } \\
\text { lower seam }\end{array}$ \\
\hline Fulton & Herrin & 249 & 243 & 7 & 7 & $\begin{array}{l}\text { Some production probably } \\
\text { from Knox County }\end{array}$ \\
\hline Fulton & Rock Island & 5 & 8 & & 0.1 & \\
\hline Gallatin & Herrin & 122 & 178 & & 6 & New mapping \\
\hline Gallatin & Springfield & 116 & 103 & 13 & 2 & $\begin{array}{l}\text { ug mining of sf } \\
\text { resources }\end{array}$ \\
\hline Greene & Colchester & 501 & 503 & & 0.1 & \\
\hline Grundy & Colchester & 313 & 306 & 7 & 0.6 & \\
\hline Jackson & Herrin & 149 & 79 & 70 & 33 & Revised mapping \\
\hline Jackson & Springfield & 100 & 97 & 3 & 4 & New mapping \\
\hline Jackson & Murphysboro & 130 & 135 & & 1 & New mapping \\
\hline Jefferson & Opdyke & 22 & 23 & & 0.4 & \\
\hline Kankakee & Houchin Creek & 16 & 15 & 1 & 0.1 & \\
\hline Kankakee & Colchester & 12 & 12 & & 3 & $\begin{array}{l}\text { Some production from Will } \\
\text { or Grundy County }\end{array}$ \\
\hline Knox & Danville & 3 & 1 & 1 & 0 & $\begin{array}{l}\text { Destroyed by mining of } \\
\text { lower seam }\end{array}$ \\
\hline $\begin{array}{l}\text { Knox } \\
\text { La Salle }\end{array}$ & $\begin{array}{l}\text { Springfield } \\
\text { Colchester }\end{array}$ & $\begin{array}{l}627 \\
209\end{array}$ & $\begin{array}{l}621 \\
265\end{array}$ & 5 & $\begin{array}{l}3 \\
0.01\end{array}$ & $\begin{array}{l}\text { Incomplete reporting } \\
\text { New mapping }\end{array}$ \\
\hline McDonough & Colchester & 584 & 579 & 6 & 6 & \\
\hline Mercer & Rock Island & 55 & 54 & 1 & 0.5 & \\
\hline Peoria & Danville & 283 & 276 & 6 & 0 & $\begin{array}{l}\text { Destroyed by mining of } \\
\text { lower seam }\end{array}$ \\
\hline Peoria & Springfield & 726 & 737 & & 1 & \\
\hline Perry & Springfield & 209 & 108 & 101 & 92 & $\begin{array}{l}\text { Mining of unmapped } \\
\text { reserves }\end{array}$ \\
\hline Saline & Danville & 78 & 69 & 10 & 0.4 & $\begin{array}{l}\text { Incomplete reporting; } \\
\text { destroyed by mining }\end{array}$ \\
\hline Saline & Herrin & 285 & 215 & 70 & 38 & $\begin{array}{l}\text { ug mining of sf } \\
\text { resources }\end{array}$ \\
\hline Saline & Springfield & 93 & 89 & 4 & 2 & $\begin{array}{l}\text { ug mining of sf } \\
\text { resources }\end{array}$ \\
\hline Saline & Dekoven & 45 & 60 & & 7 & New mapping \\
\hline Saline & Davis & 44 & 71 & & 9 & Revised mapping \\
\hline Schuyler & Colchester & 606 & 600 & 6 & 6 & \\
\hline Stark & Herrin & 442 & 439 & 3 & 8 & New mapping \\
\hline Vermilion & Danville & 387 & 393 & & 0.1 & New mapping \\
\hline Williamson & Danville & 57 & 56 & & 4 & $\begin{array}{l}\text { Some production from } \\
\text { Saline County }\end{array}$ \\
\hline Williamson & Herrin & 291 & 235 & 56 & 70 & Revised mapping \\
\hline Williamson & Springfield & 200 & 184 & 16 & 7 & $\begin{array}{l}\text { ug mining of sf } \\
\text { resources }\end{array}$ \\
\hline Williamson & Dekoven & 41 & 51 & & 8 & New mapping \\
\hline Williamson & Davis & 26 & 47 & & 11 & New mapping \\
\hline
\end{tabular}

* $u g=$ underground; sf = surface minable 
Table 14 Summary of demonstrated reserve base in lllinois, as of January 1, 1996, in millions of short tons of bituminous coal.

\begin{tabular}{|c|c|c|c|c|c|c|c|c|}
\hline \multirow{2}{*}{$\begin{array}{l}\text { Heat content } \\
\text { (million Btu/ } \\
\text { short ton) }\end{array}$} & \multicolumn{7}{|c|}{ Sulfur content (Ibs sulfur/million Btu) } & \multirow{2}{*}{$\begin{array}{c}\text { Total } \\
\text { all sulfur } \\
\text { categories }\end{array}$} \\
\hline & $<0.40$ & $0.41-0.60$ & $0.61-0.83$ & $0.84-1.24$ & $1.25-1.67$ & $1.68-2.50$ & $>2.50$ & \\
\hline \multicolumn{9}{|c|}{ Minable from surface } \\
\hline $\begin{array}{l}<20 \\
20-22.99 \\
23-24.99 \\
25-25.99 \\
\text { TOTAL }\end{array}$ & $\begin{array}{l}- \\
- \\
-\end{array}$ & $\begin{array}{l}- \\
- \\
-\end{array}$ & $\begin{array}{l}- \\
4.16 \\
1.36 \\
- \\
5.52\end{array}$ & $\begin{array}{c}- \\
161.45 \\
26.42 \\
- \\
187.87\end{array}$ & $\begin{array}{c}- \\
132.20 \\
20.12 \\
- \\
152.33\end{array}$ & $\begin{array}{c}8.84 \\
501.23 \\
80.81 \\
- \\
590.88 \\
\end{array}$ & $\begin{array}{r}121.98 \\
14,102.65 \\
1,084.50 \\
372.25 \\
15,681.39 \\
\end{array}$ & $\begin{array}{r}130.82 \\
14,901.71 \\
1,213.21 \\
372.25 \\
16,617.99 \\
\end{array}$ \\
\hline \multicolumn{9}{|c|}{ Minable underground } \\
\hline $\begin{array}{c}20-22.99 \\
23-24.99 \\
25-25.99 \\
>25.99 \\
\text { TOTAL } \\
\end{array}$ & $\begin{array}{c}199.42 \\
2.44 \\
- \\
- \\
201.86 \\
\end{array}$ & $\begin{array}{c}683.74 \\
34.08 \\
- \\
- \\
717.82 \\
\end{array}$ & $\begin{array}{c}1,089.46 \\
255.55 \\
- \\
- \\
1,345.02 \\
\end{array}$ & $\begin{array}{c}1,660.13 \\
874.93 \\
- \\
- \\
2,535.06\end{array}$ & $\begin{array}{c}1,220.92 \\
650.75 \\
- \\
- \\
1,871.67 \\
\end{array}$ & $\begin{array}{c}2,439.41 \\
1,509.48 \\
- \\
- \\
3,948.88 \\
\end{array}$ & $\begin{array}{r}48,028.67 \\
28,712.89 \\
1,167.04 \\
9.45 \\
77,918.06 \\
\end{array}$ & $\begin{array}{r}55,321.75 \\
32,040.12 \\
1,167.04 \\
9.45 \\
88,538.37 \\
\end{array}$ \\
\hline \multicolumn{9}{|l|}{ Minable total } \\
\hline $\begin{array}{c}<20 \\
20-22.99 \\
23-24.99 \\
25-25.99 \\
>25.99 \\
\text { TOTAL }\end{array}$ & $\begin{array}{c}- \\
199.42 \\
2.44 \\
- \\
- \\
201.86\end{array}$ & $\begin{array}{c}- \\
683.74 \\
34.08 \\
- \\
\overline{717.82}\end{array}$ & $\begin{array}{c}- \\
1,0.93 .63 \\
256.91 \\
- \\
- \\
1,350.54\end{array}$ & $\begin{array}{c}- \\
1,821.58 \\
901.35 \\
- \\
- \\
2,722.93\end{array}$ & $\begin{array}{c}- \\
1,353.12 \\
670.87 \\
- \\
- \\
2,023.99\end{array}$ & $\begin{array}{r}8.84 \\
2,940.64 \\
1,590.28 \\
- \\
- \\
4,539.76\end{array}$ & $\begin{array}{r}121.98 \\
62,131.33 \\
29,797.40 \\
1,539.30 \\
9.45 \\
93,599.45\end{array}$ & $\begin{array}{r}130.82 \\
70,223.46 \\
33,253.33 \\
1,539.30 \\
9.45 \\
105,156.40\end{array}$ \\
\hline
\end{tabular}

less than 42 inches thick, coal under surface features such as towns, interstate highways, and public lands, and coal rendered inaccessible (barrier pillars, small, irregular blocks between mines, and geologic constraints) by past and future mining have been excluded. Table 15 summarizes the new accessible reserve base estimate by mining method, heat content, and sulfur content.

\section{Recoverable Reserves}

The new estimate of recoverable reserves is 38 billion tons, compared with the previous estimate of 30 billion tons (table 16). Recoverable reserves were calculated from the accessible reserve base using recovery rates of $50 \%$ for underground-minable reserves, $70 \%$ for surface-minable reserves in seams less than 48 inches thick and the Herrin Coal in northwestern Illinois, and $85 \%$ for all other surface-minable reserves. Table 16 summarizes the estimates for recoverable reserves by mining method, heat content, and sulfur content.

\section{Digital Data}

A digital database of identified resources, the DRB, accessible reserves, and recoverable reserves has been provided to the EIA. This database contains more detailed thickness and depth categories than are shown in the tables of this report, as well as data on the average and maximum stripping ratio of surface minable resources. The format of the digital database is described in appendix 5. 
Table 15 Summary of accessible reserve base in Illinois, as of January 1, 1996, in millions of short tons of bituminous coal.

\begin{tabular}{|c|c|c|c|c|c|c|c|c|}
\hline \multirow{2}{*}{$\begin{array}{l}\text { Heat content } \\
\text { (million Btu/ } \\
\text { short ton) }\end{array}$} & \multicolumn{7}{|c|}{ Sulfur content (lbs sulfur/million Btu) } & \multirow{2}{*}{$\begin{array}{c}\text { Total } \\
\text { all sulfur } \\
\text { categories }\end{array}$} \\
\hline & $<0.40$ & $0.41-0.60$ & $0.61-0.83$ & $0.84-1.24$ & $1.25-1.67$ & $1.68-2.50$ & $>2.50$ & \\
\hline \multicolumn{9}{|c|}{ Minable from surface } \\
\hline $\begin{array}{l}<20 \\
20-22.99 \\
23-24.99 \\
25-25.99 \\
\text { TOTAL }\end{array}$ & $\begin{array}{l}- \\
- \\
-\end{array}$ & $\begin{array}{l}- \\
- \\
-\end{array}$ & $\begin{array}{c}- \\
3.54 \\
0.82 \\
- \\
4.36\end{array}$ & $\begin{array}{c}- \\
135.96 \\
0.85 \\
- \\
136.81\end{array}$ & $\begin{array}{c}- \\
109.34 \\
5.24 \\
- \\
114.58\end{array}$ & $\begin{array}{r}7.46 \\
393.12 \\
39.09 \\
- \\
439.67\end{array}$ & $\begin{array}{r}101.69 \\
11,403.12 \\
828.44 \\
293.43 \\
12,626.68\end{array}$ & $\begin{array}{r}109.15 \\
12,045.08 \\
874.44 \\
293.43 \\
13,322.11\end{array}$ \\
\hline \multicolumn{9}{|c|}{ Minable underground } \\
\hline $\begin{array}{l}20-22.99 \\
23-24.99 \\
25-25.99 \\
\text { TOTAL }\end{array}$ & $\begin{array}{c}91.17 \\
1.07 \\
- \\
92.24\end{array}$ & $\begin{array}{c}353.50 \\
16.58 \\
- \\
370.08\end{array}$ & $\begin{array}{c}651.21 \\
160.36 \\
- \\
811.57\end{array}$ & $\begin{array}{c}900.59 \\
633.11 \\
- \\
1,533.70\end{array}$ & $\begin{array}{r}712.67 \\
452.48 \\
- \\
1,165.15\end{array}$ & $\begin{array}{c}1,393.41 \\
1,108.46 \\
- \\
2,501.87\end{array}$ & $\begin{array}{r}30,360.59 \\
18,871.96 \\
533.51 \\
49,766.07\end{array}$ & $\begin{array}{r}34,463.14 \\
21,244.02 \\
533.51 \\
56,240.68\end{array}$ \\
\hline \multicolumn{9}{|l|}{ Minable total } \\
\hline $\begin{array}{l}<20 \\
20-22.99 \\
23-24.99 \\
25-25.99 \\
\text { TOTAL }\end{array}$ & $\begin{array}{l}\overline{-} \\
91.17 \\
1.07 \\
\overline{92.24}\end{array}$ & $\begin{array}{c}- \\
353.50 \\
16.58 \\
- \\
370.08\end{array}$ & $\begin{array}{c}- \\
654.75 \\
161.18 \\
- \\
815.93\end{array}$ & $\begin{array}{c}- \\
1,036.55 \\
633.96 \\
- \\
1,670.50\end{array}$ & $\begin{array}{c}- \\
822.01 \\
457.73 \\
- \\
1,279.73\end{array}$ & $\begin{array}{r}7.46 \\
1,786.53 \\
1,147.55 \\
- \\
2,941.54\end{array}$ & $\begin{array}{r}101.69 \\
41,763.71 \\
19,700.40 \\
826.95 \\
62,392.75\end{array}$ & $\begin{array}{r}109.15 \\
46,508.22 \\
22,118.46 \\
826.95 \\
69,562.78\end{array}$ \\
\hline
\end{tabular}

Table 16 Summary of recoverable reserve base in Illinois, as of January 1, 1996, in millions of short tons of bituminous coal.

\begin{tabular}{|c|c|c|c|c|c|c|c|c|}
\hline \multirow{2}{*}{$\begin{array}{l}\text { Heat content } \\
\text { (million Btu/ } \\
\text { short ton) }\end{array}$} & \multicolumn{7}{|c|}{ Sulfur content (lbs sulfur/million Btu) } & \multirow{2}{*}{$\begin{array}{c}\text { Total } \\
\text { all sulfur } \\
\text { categories }\end{array}$} \\
\hline & $<0.40$ & $0.41-0.60$ & $0.61-0.83$ & $0.84-1.24$ & $1.25-1.67$ & $1.68-2.50$ & $>2.50$ & \\
\hline \multicolumn{9}{|c|}{ Minable from surface } \\
\hline $\begin{array}{l}<20 \\
20-22.99 \\
23-24.99 \\
25-25.99 \\
\text { TOTAL }\end{array}$ & $\begin{array}{l}- \\
- \\
- \\
-\end{array}$ & $\begin{array}{l}- \\
- \\
- \\
-\end{array}$ & $\begin{array}{l}- \\
2.48 \\
0.70 \\
- \\
3.18\end{array}$ & $\begin{array}{c}\overline{-} \\
110.69 \\
0.72 \\
- \\
111.41\end{array}$ & $\begin{array}{c}- \\
87.11 \\
4.46 \\
- \\
91.57\end{array}$ & $\begin{array}{r}5.22 \\
303.37 \\
30.94 \\
- \\
339.53\end{array}$ & $\begin{array}{r}71.18 \\
8,586.19 \\
682.05 \\
226.75 \\
9,566.17\end{array}$ & $\begin{array}{r}76.41 \\
9,089.84 \\
718.86 \\
226.75 \\
10,111.86\end{array}$ \\
\hline \multicolumn{9}{|c|}{ Minable underground } \\
\hline $\begin{array}{l}20-22.99 \\
23-24.99 \\
25-25.99 \\
\text { TOTAL }\end{array}$ & $\begin{array}{c}45.58 \\
0.54 \\
\overline{46.12}\end{array}$ & $\begin{array}{c}176.75 \\
8.29 \\
- \\
185.04\end{array}$ & $\begin{array}{c}325.61 \\
80.18 \\
- \\
405.79\end{array}$ & $\begin{array}{c}450.29 \\
316.55 \\
- \\
766.85\end{array}$ & $\begin{array}{c}356.33 \\
226.24 \\
- \\
582.58\end{array}$ & $\begin{array}{c}696.70 \\
554.23 \\
- \\
1,250.93\end{array}$ & $\begin{array}{r}15,180.30 \\
9,435.98 \\
266.76 \\
24,883.03\end{array}$ & $\begin{array}{r}17,231.57 \\
10,622.01 \\
266.76 \\
28,120.34\end{array}$ \\
\hline \multicolumn{9}{|l|}{ Minable total } \\
\hline $\begin{array}{l}<20 \\
20-22.99 \\
23-24.99 \\
25-25.99 \\
\text { TOTAL }\end{array}$ & $\begin{array}{c}- \\
45.59 \\
0.54 \\
\overline{46.12}\end{array}$ & $\begin{array}{c}- \\
176.75 \\
8.29 \\
- \\
18 \overline{5} .04\end{array}$ & $\begin{array}{c}- \\
328.09 \\
80.88 \\
- \\
408.96\end{array}$ & $\begin{array}{c}- \\
560.99 \\
317.28 \\
- \\
87 \overline{8} .26\end{array}$ & $\begin{array}{c}\overline{-} \\
443.45 \\
230.70 \\
- \\
674.14\end{array}$ & $\begin{array}{r}5.22 \\
1,000.07 \\
585.17 \\
- \\
1,590.47\end{array}$ & $\begin{array}{r}71.18 \\
23,766.48 \\
10,118.03 \\
493.51 \\
34,449.20\end{array}$ & $\begin{array}{r}76.41 \\
26,321.41 \\
11,340.88 \\
493.51 \\
38,232.20\end{array}$ \\
\hline
\end{tabular}




\section{REFERENCES}

Allgaier, G.J., and M.E. Hopkins, 1975, Reserves of the Herrin (No. 6) Coal in the Fairfield Basin in Southeastern Illinois: Illinois State Geological Survey Circular 489, 31 p.

ASTM, 1990, Annual Book of ASTM Standards, Section 5, Petroleum Products, Lubricants, and Fossil Fuels, Volume 5.05 Gaseous Fuels; Coal and Coke: American Society for Testing and Materials, Philadelphia, PA, $472 \mathrm{p}$.

Averitt, P.A., 1969, Coal Resources of the United States January 1, 1967, U.S. Geological Survey Bulletin 1275, $116 \mathrm{p}$.

Cady, G.H., 1952, Minable Coal Reserves of Illinois: Illinois State Geological Survey Bulletin 78, 138 p.

Campbell, M.R., 1913, The coal reserves of the United States, in The Coal Resources of the World, W. McInnes, D.D. Dowling, and W.W. Leach, editors: Toronto, Morang \& Co., Ltd., v. 2, p. $525-539$.

Damberger, H.H., 1970, Clastic dikes and related impurities in Herrin (No. 6) and Springfield (No. 5) Coals of the lllinois Basin, in W.H. Smith, R.B. Nance, M.E. Hopkins, R.G. Johnson, and C.W. Shabica, Depositional Environments in Parts of the Carbondale Formation-Western and Northern Illinois: Illinois State Geological Survey Guidebook 8, p. 111-119.

Damberger, H.H., 1971, Coalification pattern of the Illinois Basin: Economic Geology, v. 66, p. $488-494$.

DeMaris, P.J., 1973, Illinois coal reserve data by county and coal seam: Illinois State Geological Survey, unpublished notes.

Demir, I., R.D. Harvey, R.R. Ruch, H.H. Damberger, C. Chaven, J.D. Steele, and W.T. Frankie, 1994, Characterization of Available (Marketed) Coals from Illinois Mines: Illinois State Geological Survey, Open File Series 1994-2, 26 p.

Eggleston, J.R., M.D. Carter, and J.C. Cobb, 1990, Coal Resources Available for Development-A Methodology and Pilot Study: U.S. Geological Survey Circular 1055, $15 \mathrm{p}$.

Energy Information Administration, 1995, Coal Data, A Reference: Office of Coal, Nuclear, Electric and Alternate Fuels, U.S. Department of Energy, 128 p.

Energy Information Administration, 1996, U.S. Coal Reserves-A Review and Update: Office of Coal, Nuclear, Electric and Alternate Fuels, U.S. Department of Energy, $105 \mathrm{p}$.

Gluskoter, H.J., and M.E. Hopkins, 1970, Distribution of sulfur in Illinois coals, in W.H. Smith, R.B. Nance, M.E. Hopkins, R.G. Johnson, and C.W. Shabica, Depositional Environments in Parts of the Carbondale Formation-Western and Northern Illinois: Illinois State Geological Survey Guidebook 8, p. 89-95.

Gluskoter, H.J., and J.A. Simon, 1968, Sulfur in Illinois Coals: Illinois State Geological Survey Circular 432, $28 \mathrm{p}$.

Helfinstine, R.J., N.F. Shimp, M.E. Hopkins, and J.A. Simon, 1974, Sulfur Reduction of Illinois Coals-Washability Studies, Part 2: Illinois State Geological Survey Circular 484, $32 \mathrm{p}$.

Helfinstine, R.J., N.F. Shimp, J.A. Simon, and M.E. Hopkins, 1971, Sulfur Reduction of llinois Coals-Washability Studies, Part 1: Illinois State Geological Survey Circular 462, 44 p.

Holmes, J.A., 1911, The Sampling of Coal in the Mine: U.S. Bureau of Mines, Technical Paper 1, 18 p.

Hopkins, M.E., 1968, Harrisburg (No. 5) Coal Reserves of Southeastern Illinois: Illinois State Geological Survey Circular 431, $25 \mathrm{p}$.

Illinois Department of Energy and Natural Resources, 1982, Illinois Energy Plan, Volume IV, An Inventory of the Coal Resources of Illinois: IDENR, ILLDOE 82/13, 66 p.

Illinois Department of Mines and Minerals, 1993, Citizen's Guide to Coal Mining and Reclamation in Illinois: Illinois Department of Mines and Minerals, Land Reclamation Division, $31 \mathrm{p}$.

Illinois Department of Mines and Minerals, 1994, 1993 Annual Statistical Report: Illinois Department of Mines and Minerals, $29 \mathrm{p}$.

Jacobson, R.J., 1983, Murphysboro Coal, Jackson and Perry Counties-Resources with Low to Medium Sulfur Potential: Illinois State Geological Survey, Illinois Minerals Note 85, 19 p.

Jacobson, R.J., 1985, Coal Resources of Grundy, La Salle, and Livingston Counties, Illinois: Illinois State Geological Survey Circular 536, 58 p.

Jacobson, R.J., 1993, Coal Resources of the Dekoven and Davis Members (Carbondale Formation) in Gallatin and Saline Counties, Southeastern Illinois: Illinois State Geological Survey Circular $551,41 \mathrm{p}$.

Jacobson, R.J., and L.E. Bengal, 1981, Strippable Coal Resources of Illinois, Part 7-Vermilion and Edgar Counties: Illinois State Geological Survey Circular 521, 24 p. 
Jacobson, R.J., C.G. Treworgy, and C.A. Chenoweth, 1996, Availability of Coal Resources for Mining in Illinois-Mt. Carmel Quadrangle, Southeastern Illinois: Illinois State Geological Survey, Illinois Minerals 114, $39 \mathrm{p}$.

Nance, R.B., and C.G. Treworgy, 1981, Strippable Coal Resources of Illinois, Part 8-Central and Southeastern Counties: Illinois State Geological Survey Circular 515, 32 p.

Nelson, W.J., 1981, Faults and Their Effect on Coal Mining in Illinois: Illinois State Geological Survey Circular 523, $40 \mathrm{p}$.

Robinson, J.E., 1982, Computer Applications in Petroleum Geology. Stroudsburg, PA, Hutchinson Ross Publishing Company, $164 \mathrm{p}$.

Reinertsen, D.L., 1964, Strippable Coal Reserves of Illinois, Part 4-Adams, Brown, Calhoun, Hancock, McDonough, Pike, Schuyler, and the Southern Parts of Henderson and Warren Counties: Illinois State Geological Survey Circular 374, 32 p.

Smith, W.H., 1957, Strippable Coal Reserves of Illinois, Part 1-Gallatin, Hardin, Johnson, Pope, Saline, and Williamson Counties: Illinois State Geological Survey Circular 228, 39 p.

Smith, W.H., 1958, Strippable Coal Reserves of Illinois, Part 2-Jackson, Monroe, Perry, Randolph, and St. Clair Counties: Illinois State Geological Survey Circular 260, 35 p.

Smith, W.H., 1961, Strippable Coal Reserves of Illinois, Part 3-Madison, Macoupin, Jersey, Greene, Scott, Morgan, and Cass Counties: Illinois State Geological Survey Circular 311, 40 p.

Smith, W.H., 1968, Strippable Coal Reserves of Illinois, Part 6-La Salle, Livingston, Grundy, Kankakee, Will, Putnam, and Parts of Bureau and Marshall Counties: Illinois State Geological Survey Circular 419, 29 p.

Smith, W.H., and D.J. Berggren, 1963, Strippable Coal Reserves of Illinois, Part 5A-Fulton, Henry, Knox, Peoria, Stark, Tazewell, and Parts of Bureau, Marshall, Mercer, and Warren Counties: Illinois State Geological Survey Circular 348, 59 p.

Smith, W.H., and J.B. Stall, 1975, Coal and Water Resources for Coal Conversion in Illinois: Illinois State Water Survey and Illinois State Geological Survey, Cooperative Resources Report 4, 79 p., 3 pl.

Treworgy, C.G., 1981, The Seelyville Coal-A Major Unexploited Seam in Illinois: Illinois State Geological Survey, Illinois Mineral Notes $80,11 \mathrm{p}$.

Treworgy, C.G., 1995, Thickness of the Herrin Coal in Moultrie County: Illinois State Geological Survey, unpublished work map.

Treworgy, C.G., and M.H. Bargh, 1982, Deep-Minable Coal Resources of Illinois: Illinois State Geological Survey Circular 527, $65 \mathrm{p}$.

Treworgy, C.G., L.E. Bengal, and A.G. Dingwell, 1978, Reserves and Resources of SurfaceMinable Coal: Illinois State Geological Survey Circular 504, 44 p.

Treworgy, C.G., C.A. Chenoweth, and M.H. Bargh, 1995, Availability of Coal Resources for Mining in Illinois: Galatia Quadrangle, Saline and Hamilton Counties, Southeastern Illinois: Illinois State Geological Survey, Illinois Minerals 113, 42 p.

Treworgy, C.G., C.A. Chenoweth, and R.J. Jacobson, 1996a, Availability of Coal Resources for Mining in Illinois, Newton and Princeville Quadrangles, Jasper, Peoria, and Stark Counties: Illinois State Geological Survey, Open File Series 1996-3, 47 p.

Treworgy, C.G., C.A. Chenoweth, and M.A. Justice, 1996b, Availability of Coal Resources for Mining in Illinois, Atwater, Collinsville, and Nokomis Quadrangles, Christian, Macoupin, Madison, Montgomery, and St. Clair Counties: Illinois State Geological Survey, Open File Series 1996-2, $33 \mathrm{p}$.

Treworgy, C.G., G.K. Coats, and M.H. Bargh, 1994, Availability of Coal Resources for Mining in Illinois, Middletown Quadrangle, Central Illinois: Illinois State Geological Survey Circular 554, $48 \mathrm{p}$.

Treworgy, C.G., and R.J. Jacobson, 1986, Paleoenvironments and distribution of low-sulfur coal in Illinois, in Aureal T. Cross, editor, Economic Geology-Coal, Oil and Gas, Compte Rendu, v. 4, Ninth International Congress of Carboniferous Stratigraphy and Geology, Washington and Champaign-Urbana, May 1979: Southern Illinois University Press, Carbondale, p. 349-359.

Treworgy, J.D., 1981, Structural Features in Illinois-A Compendium: Illinois State Geological Survey Circular 519, 22 p., 1 plate. 
U.S. Bureau of Mines, 1995, Coal Recoverability and Coal Reserve Analysis, Appalachian and Illinois Basins, 1994: U.S. Bureau of Mines Coal Recoverability Series Report 4, Open File Report 02-95, $41 \mathrm{p}$.

Wood, G.W., Jr., T.M. Kehn, M.D. Carter, and W.C. Culbertson, 1983, Coal Resource Classification System of the U.S. Geological Survey, U.S. Geological Survey Circular 891, 65 p. 
APPENDIX 1 Source maps for coal resources

\begin{tabular}{|c|c|c|c|c|c|c|}
\hline County & Seam & $\begin{array}{c}\text { Source } \\
\text { (ISGS publications) }\end{array}$ & $\begin{array}{l}\text { Map } \\
\text { year }\end{array}$ & $\begin{array}{c}\text { Scale } \\
(\times 1000)\end{array}$ & $\begin{array}{l}\text { Subsequent } \\
\text { mining * }\end{array}$ & $\begin{array}{l}\text { Revi- } \\
\text { sion }^{\star \star}\end{array}$ \\
\hline Adams & Colchester & Reinertsen 1964 & 1964 & 125 & & \\
\hline Bond & Litchfield & Cady 1952 & 1950 & 62.5 & & \\
\hline Bond & Herrin & This report & 1996 & 50 & & C \\
\hline Bond & Colchester & Cady 1952 & 1950 & 62.5 & & \\
\hline Brown & Colchester & Reinertsen 1964 & 1964 & 125 & $S$ & \\
\hline Bureau & Danville & $\begin{array}{c}\text { Cady } 1952, \text { Smith and Berg- } \\
\text { gren } 1963, \text { Smith } 1968\end{array}$ & 1950 & 125 & & $N$ \\
\hline Bureau & Herrin & $\begin{array}{c}\text { Cady } 1952, \text { Smith and Berg- } \\
\text { gren } 1963, \text { Smith } 1968\end{array}$ & 1950 & 125 & & $N$ \\
\hline Bureau & Colchester & $\begin{array}{c}\text { Cady } 1952, \text { Smith and Berg- } \\
\text { gren } 1963, \text { Smith } 1968\end{array}$ & 1950 & 125 & & $\mathbf{N}$ \\
\hline Calhoun & Colchester & Reinertsen 1964 & 1964 & 125 & & \\
\hline Cass & Herrin & Smith 1961 & 1961 & 125 & & \\
\hline Cass & Springfield & Nance and Treworgy 1981 & 1981 & 125 & & $\mathbf{N}$ \\
\hline Cass & Colchester & Smith 1961 & 1961 & 125 & & \\
\hline Champaign & Danville & Treworgy and Bargh 1982 & 1978 & 62.5 & & $N$ \\
\hline Champaign & Herrin & Treworgy and Bargh 1982 & 1978 & 62.5 & & $\mathbf{N}$ \\
\hline Christian & Danville & Cady 1952 & 1950 & 62.5 & & \\
\hline Christian & Herrin & Treworgy and Bargh 1982 & 1978 & 62.5 & $\mathrm{U}$ & $N$ \\
\hline Christian & Springfield & Treworgy and Bargh 1982 & 1978 & 62.5 & & $\mathbf{N}$ \\
\hline Christian & Assumption & Cady 1952 & 1950 & 62.5 & & \\
\hline Clark & Danville & This report & 1996 & 50 & & C \\
\hline Clark & Jamestown & This report & 1996 & 50 & & C \\
\hline Clark & Herrin & This report & 1996 & 50 & & C \\
\hline Clark & Springfield & This report & 1996 & 50 & & C \\
\hline Clark & Seelyville & Treworgy 1981 & 1978 & 62.5 & & $\mathbf{N}$ \\
\hline Clay & Herrin & Allgaier and Hopkins 1975 & 1975 & 125 & & \\
\hline Clay & Springfield & Work map by CGT & 1978 & 62.5 & & $\mathbf{N}$ \\
\hline Clay & Seelyville & Treworgy 1981 & 1978 & 62.5 & & \\
\hline Clinton & Herrin & This report & 1996 & 50 & U & C \\
\hline Coles & Danville & This report & 1996 & 50 & & C \\
\hline Coles & Herrin & This report & 1996 & 50 & & $\mathrm{C}$ \\
\hline Coles & Springfield & This report & 1996 & 50 & & C \\
\hline Coles & Seelyville & Treworgy 1981 & 1978 & 62.5 & & C \\
\hline Crawford & Bristol Hill & Nance and Treworgy 1981 & 1981 & 62.5 & & \\
\hline Crawford & Danville & This report & 1996 & 50 & & C \\
\hline Crawford & Jamestown & This report & 1996 & 50 & & C \\
\hline Crawford & Herrin & This report & 1996 & 50 & & C \\
\hline Crawford & Springfield & This report & 1996 & 50 & & C \\
\hline Crawford & Seelyville & Treworgy 1981 & 1978 & 62.5 & & \\
\hline Cumberland & Trowbridge & Nance and Treworgy 1981 & 1981 & 62.5 & & \\
\hline Cumberland & Herrin & This report & 1996 & 50 & & $\mathrm{C}$ \\
\hline Cumberland & Springfield & This report & 1996 & 50 & & $\mathrm{C}$ \\
\hline Cumberland & Seelyville & Treworgy 1981 & 1981 & 62.5 & & $N$ \\
\hline De Witt & Springtield & Treworgy and Bargh 1982 & 1978 & 62.5 & & $N$ \\
\hline Douglas & Herrin & This report & 1996 & 50 & & $\mathrm{C}$ \\
\hline Douglas & Springfield & This report & 1996 & 50 & & C \\
\hline Edgar & Danville & This report & 1996 & 50 & & C \\
\hline Edgar & Herrin & This report & 1996 & 50 & & C \\
\hline Edgar & Springfield & This report & 1996 & 50 & & C \\
\hline Edgar & Survant & Work map by CGT & 1978 & 62.5 & & \\
\hline Edgar & Seelyville & Treworgy 1981 & 1981 & 62.5 & & \\
\hline
\end{tabular}

" Under "subsequent mining," $U$ and $S$ indicate whether underground or surface mining has occurred since the resources were last mapped.

** Under "revision," $\mathrm{C}$ indicates that the seam was revised for this project; $\mathrm{N}$ indicates that new data have become available since the date of mapping and the resource/reserve map should be revised. 


\begin{tabular}{|c|c|c|c|c|c|c|}
\hline County & Seam & $\begin{array}{c}\text { Source } \\
\text { (ISGS publications) }\end{array}$ & $\begin{array}{l}\text { Map } \\
\text { year }\end{array}$ & $\begin{array}{c}\text { Scale } \\
(\times 1000)\end{array}$ & $\begin{array}{l}\text { Subsequent } \\
\text { mining }\end{array}$ & $\begin{array}{l}\text { Revi- } \\
\text { sion** }\end{array}$ \\
\hline Edwards & Herrin & Treworgy and Bargh 1982 & 1978 & 62.5 & & $\mathbf{N}$ \\
\hline Edwards & Springfield & Treworgy and Bargh 1982 & 1978 & 62.5 & & $\mathbf{N}$ \\
\hline Effingham & Shelbyville & Nance and Treworgy 1981 & 1981 & 62.5 & & \\
\hline Effingham & Herrin & This report & 1996 & 50 & & $\mathrm{C}$ \\
\hline Effingham & Springfield & This report & 1996 & 50 & & C \\
\hline Effingham & Seelyville & Treworgy 1981 & 1981 & 62.5 & & $\mathbf{N}$ \\
\hline Fayette & Shelbyville & Nance and Treworgy 1981 & 1981 & 62.5 & & \\
\hline Fayette & Louden & Nance and Treworgy 1981 & 1981 & 62.5 & & \\
\hline Fayette & Danville & Cady 1952 & 1950 & 62.5 & & \\
\hline Fayette & Herrin & This report & 1996 & 50 & & C \\
\hline Fayette & Springfield & Work map by CGT & 1978 & 62.5 & & \\
\hline Franklin & Belle Rive & Nance and Treworgy 1981 & 1981 & 62.5 & & \\
\hline Franklin & Herrin & Treworgy and Bargh 1982 & 1978 & 62.5 & $\mathbf{U}$ & $N$ \\
\hline Franklin & Springfield & Treworgy and Bargh 1982 & 1978 & 62.5 & & \\
\hline Franklin & Dekoven & Cady 1952 & 1950 & 62.5 & & \\
\hline Franklin & Davis & Cady 1952 & 1950 & 62.5 & & \\
\hline Franklin & Mt. Rorah & Cady 1952 & 1950 & 62.5 & & \\
\hline Fulton & Danville & Smith and Berggren 1963 & 1963 & 125 & $\mathbf{S}$ & $\mathbf{N}$ \\
\hline Fulton & Herrin & Smith and Berggren 1963 & 1963 & 125 & $\mathbf{S}$ & $N$ \\
\hline Fulton & Springfield & Smith and Berggren 1963 & 1963 & 125 & $\mathbf{S}$ & $\mathbf{N}$ \\
\hline Fulton & Colchester & Snnith and Berggren 1963 & 1963 & 125 & $\mathbf{S}$ & $\mathbf{N}$ \\
\hline Fulton & Rock Island & Smith and Berggren 1963 & 1963 & 125 & & \\
\hline Gallatin & Herrin & $\begin{array}{l}\text { Treworgy and Bargh 1982, } \\
\text { Smith } 1957\end{array}$ & 1957 & 62.5 & US & $\mathbf{N}$ \\
\hline Gallatin & Springfield & Circulars 527,228 & 1957 & 62.5 & US & $\mathbf{N}$ \\
\hline Gallatin & Dekoven & Jacobson 1993 & 1993 & 62.5 & $\mathrm{~S}$ & \\
\hline Gallatin & Davis & Jasobson 1993 & 1993 & 62.5 & $\mathrm{~S}$ & \\
\hline Gallatin & Willis & Cady 1952 & 1950 & 62.5 & & \\
\hline Greene & Herrin & Smith 1961 & 1961 & 125 & & \\
\hline Greene & Colchester & Smith 1961, Cady 1952 & 1950 & 125 & & \\
\hline Grundy & Herrin & Jacobson 1985 & 1985 & 62.5 & & \\
\hline Grundy & Houchin Creek & Jacobson 1985 & 1985 & 62.5 & & \\
\hline Grundy & Colchester & Jacobson 1985 & 1985 & 62.5 & $\mathbf{S}$ & \\
\hline Hamilton & Herrin & Treworgy and Bargh 1982 & 1978 & 62.5 & & \\
\hline Hamilton & Springfield & Treworgy and Bargh 1982 & 1978 & 62.5 & $\mathbf{U}$ & \\
\hline Hamilton & Dekoven & Cady 1952 & 1950 & 62.5 & & \\
\hline Hamilton & Davis & Cady 1952 & 1950 & 62.5 & & \\
\hline Hancock & Colchester & Reinertsen 1964 & 1964 & 125 & & \\
\hline Henderson & Colchester & Reinertsen 1964 & 1964 & 125 & & \\
\hline Henry & Danville & Smith and Berggren 1963 & 1963 & 125 & & $N$ \\
\hline Henry & Herrin & Smith and Berggren 1963 & 1963 & 125 & & $\mathbf{N}$ \\
\hline Henry & Colchester & Smith and Berggren 1963 & 1963 & 125 & & $N$ \\
\hline Henry & Rock Island & Searight and Smith 1969 & 1969 & 125 & & \\
\hline Jackson & Seahorne & Smith 1957 & 1957 & 125 & & \\
\hline Jackson & Herrin & Smith 1958 & 1958 & 125 & $S$ & $N$ \\
\hline Jackson & Springfield & $\begin{array}{l}\text { Smith 1958, Treworgy and } \\
\text { Bargh } 1982\end{array}$ & 1958 & 125 & & \\
\hline Jackson & Murphysboro & Jacobson 1983 & 1983 & 125 & & $\mathbf{N}$ \\
\hline Jasper & Herrin & This report & 1996 & 50 & & $\mathrm{C}$ \\
\hline Jasper & Springfield & This report & 1996 & 50 & & $\mathrm{C}$ \\
\hline Jasper & Seelyville & Treworgy 1981 & 1981 & 62.5 & & $\mathbf{N}$ \\
\hline Jefferson & Opdyke & Nance and Treworgy 1981 & 1981 & 62.5 & $S$ & \\
\hline Jefferson & Belle Rive & Nance and Treworgy 1981 & 1981 & 62.5 & & \\
\hline Jefferson & Herrin & Treworgy and Bargh 1982 & 1978 & 62.5 & $\mathrm{U}$ & $\mathbf{N}$ \\
\hline Jefferson & Springfield & Treworgy and Bargh 1982 & 1978 & 62.5 & & $N$ \\
\hline Jersey & Herrin & Smith 1961 & 1961 & 125 & & \\
\hline Jersey & Colchester & Cacly 1952, Smith 1961 & 1950 & 125 & & \\
\hline Johnson & New Burnside & no mapped resources & & & $S$ & \\
\hline
\end{tabular}




\begin{tabular}{|c|c|c|c|c|c|c|}
\hline County & Seam & $\begin{array}{c}\text { Source } \\
\text { (ISGS publications) }\end{array}$ & $\begin{array}{l}\text { Map } \\
\text { year }\end{array}$ & $\begin{array}{c}\text { Scale } \\
(\times 1000)\end{array}$ & $\begin{array}{l}\text { Subsequent } \\
\text { mining }\end{array}$ & $\begin{array}{l}\text { Revi- } \\
\text { sion** }\end{array}$ \\
\hline Kankakee & Houchin Creek & Smith 1968 & 1968 & 125 & & \\
\hline Kankakee & Colchester & Cady 1952, Smith 1968 & 1950 & 125 & & \\
\hline Knox & Danville & Smith and Berggren 1963 & 1963 & 125 & $S$ & $\mathbf{N}$ \\
\hline Knox & Herrin & Smith and Berggren 1963 & 1963 & 125 & $S$ & $\mathbf{N}$ \\
\hline Knox & Springfield & Smith and Berggren 1963 & 1963 & 125 & $\mathbf{S}$ & $\mathbf{N}$ \\
\hline Knox & Colchester & $\begin{array}{l}\text { Cady } 1952, \text { Smith and Berg- } \\
\text { gren } 1963\end{array}$ & 1950 & 125 & & $\mathbf{N}$ \\
\hline Knox Rock & Island & Cady 1952 & 1950 & 62.5 & & \\
\hline La Salle & Danville & Jacobson 1985 & 1985 & 62.5 & & \\
\hline La Salle & Herrin & Jacobson 1985 & 1985 & 62.5 & & \\
\hline La Salle & Houchin Creek & Jacobson 1985 & 1985 & 62.5 & & \\
\hline La Salle & Colchester & Jacobson 1985 & 1985 & 62.5 & & \\
\hline Lawrence & Danville & This report & 1996 & 50 & & C \\
\hline Lawrence & Jamestown & This report & 1996 & 50 & & $\mathrm{C}$ \\
\hline Lawrence & Herrin & This report & 1996 & 50 & & $\mathrm{C}$ \\
\hline Lawrence & Springfield & This report & 1996 & 50 & & C \\
\hline Lawrence & Survant & Cady 1952 & 1950 & 62.5 & & \\
\hline Lawrence & Seelyville & Treworgy 1981 & 1981 & 62.5 & & \\
\hline Livingston & Danville & Jacobson 1985 & 1985 & 62.5 & & \\
\hline Livingston & Herrin & Jacobson 1985 & 1985 & 62.5 & & \\
\hline Livingston & Houchin Creek & Jacobson 1985 & 1985 & 62.5 & & \\
\hline Livingston & Colchester & Jacobson 1985 & 1985 & 62.5 & & \\
\hline Logan & Danville & no mapped resources & & & & $\mathbf{N}$ \\
\hline Logan & Herrin & Work map by JDT & 1983 & 62.5 & & $\mathbf{N}$ \\
\hline Logan & Springfield & Treworgy and Bargh 1982 & 1978 & 62.5 & $\mathbf{U}$ & $\mathbf{N}$ \\
\hline McDonough & Colchester & Reinertsen 1964 & 1964 & 125 & $\mathbf{S}$ & $\mathbf{N}$ \\
\hline McLean & Danville & Cady 1952 & 1950 & 62.5 & & $\mathbf{N}$ \\
\hline McLean & Springfield & Treworgy and Bargh 1982 & 1978 & 62.5 & & $\mathbf{N}$ \\
\hline McLean & Colchester & Cady 1952 & 1950 & 62.5 & & $N$ \\
\hline Macon & Herrin & Treworgy and Bargh 1982 & 1978 & 62.5 & & \\
\hline Macon & Springfield & Treworgy and Bargh 1982 & 1978 & 62.5 & & \\
\hline Macoupin & Wiley & Cady 1952 & 1950 & 62.5 & & \\
\hline Macoupin & Danville & Cady 1952 & 1950 & 62.5 & & \\
\hline Macoupin & Herrin & $\begin{array}{l}\text { Smith 1963, Treworgy and } \\
\text { Bargh } 1982\end{array}$ & $1963 \dagger$ & 62.5 & $\mathrm{U}$ & $\mathbf{N}$ \\
\hline Macoupin & Houchin Creek & $\begin{array}{l}\text { Cady 1952, Treworgy and } \\
\text { Bargh } 1982\end{array}$ & 1950 & 62.5 & & \\
\hline Macoupin & Colchester & Cady 1952, Smith 1961 & 1950 & 62.5 & & \\
\hline Macoupin & Litchfield & Cady 1952 & 1950 & 62.5 & & \\
\hline Madison & Wiley & Cady 1952 & 1950 & 62.5 & & \\
\hline Madison & Herrin & $\begin{array}{l}\text { Smith 1963, Treworgy and } \\
\text { Bargh } 1982\end{array}$ & 1963 & 62.5 & & $\mathbf{N}$ \\
\hline Madison & Colchester & Cady 1952, Smith 1961 & 1950 & 62.5 & & \\
\hline Madison & Litchfield & Cady 1952 & 1950 & 62.5 & & \\
\hline Marion & Herrin & Treworgy and Bargh 1982 & 1978 & 62.5 & & \\
\hline Marion & Springfield & Work map by CGT & 1978 & 62.5 & & \\
\hline Marshall & Danville & $\begin{array}{l}\text { Cady } 1952, \text { Smith and Berg- } \\
\text { gren } 1963\end{array}$ & 1950 & 62.5 & & \\
\hline Marshall & Herrin & Cady 1952 & 1950 & 62.5 & & \\
\hline Marshall & Colchester & Cady 1952 & 1950 & 62.5 & & \\
\hline Mason & Springfield & Treworgy and Bargh 1982 & 1978 & 62.5 & & \\
\hline Menard & Danville & no mapped resources & & & & \\
\hline Menard & Herrin & no mapped resources & & & & $\mathbf{N}$ \\
\hline Menard & Springfield & Treworgy and Bargh 1982 & 1978 & 62.5 & & $\mathbf{N}$ \\
\hline Mercer & Colchester & $\begin{array}{l}\text { Reinertsen 1964, Searight } \\
\text { and Smith } 1969\end{array}$ & 1964 & 125 & & $\ddot{N}$ \\
\hline
\end{tabular}


APPENDIX 1 continued

\begin{tabular}{|c|c|c|c|c|c|c|}
\hline County & Seam & $\begin{array}{c}\text { Source } \\
\text { (ISGS publications) }\end{array}$ & $\begin{array}{l}\text { Map } \\
\text { year }\end{array}$ & $\begin{array}{c}\text { Scale } \\
(\times 1000)\end{array}$ & $\begin{array}{c}\text { Subsequent } \\
\text { mining * }\end{array}$ & $\begin{array}{l}\text { Revi- } \\
\text { sion }{ }^{\star \star}\end{array}$ \\
\hline Mercer & Rock Island & $\begin{array}{l}\text { Reinertsen } 1964, \text { Searight } \\
\text { and Smith } 1969\end{array}$ & 1964 & 125 & & \\
\hline Monroe & Herrin & Smith 1958 & 1958 & 125 & & \\
\hline Montgomery & Danville & Cady 1952 & 1950 & 62.5 & & \\
\hline Montgomery & Herrin & Treworgy and Bargh 1982 & $1978 t$ & 62.5 & $U$ & $\mathbf{N}$ \\
\hline Montgomery & Houchin Creek & Cady 1952 & 1950 & 62.5 & & \\
\hline Montgomery & Colchester & Ciady 1952 & 1950 & 62.5 & & \\
\hline Montgomery & Litchfield & Cady 1952 & 1950 & 62.5 & & \\
\hline Montgomery & Wiley & Cady 1952 & 1950 & 62.5 & & \\
\hline Morgan & Herrin & $\begin{array}{l}\text { Smith } 1961, \text { Treworgy and } \\
\text { Bargh } 1982\end{array}$ & 1961 & 125 & & \\
\hline Morgan & Springfield & Smith 1961 & 1961 & 125 & & $\mathbf{N}$ \\
\hline Morgan & Colchester & Sinith 1961, Cady 1952 & 1950 & 125 & & $N$ \\
\hline Moultrie & Herrin & This report & 1995 & 50 & & $\mathrm{C}$ \\
\hline Peoria & Danville & Srnith and Berggren 1963 & 1963 & 125 & $S$ & $N$ \\
\hline Peoria & Herrin & Srnith and Berggren 1963 & 1963 & 125 & $\mathrm{~S}$ & $N$ \\
\hline Peoria & Springfield & Srnith and Berggren 1963 & 1963 & 125 & & $N$ \\
\hline Peoria & Colchester & $\begin{array}{l}\text { Srnith and Berggren 1963, } \\
\text { Cady } 1952\end{array}$ & 1950 & 125 & & $N$ \\
\hline Perry & Danville & no mapped resources & & & 5 & \\
\hline Perry & Herrin & $\begin{array}{l}\text { Smith 1958, Treworgy and } \\
\text { Bargh } 1982\end{array}$ & 1958 & 62.5 & US & \\
\hline Perry & Springfield & $\begin{array}{l}\text { Srnith 1958, Treworgy and } \\
\text { Bargh } 1982\end{array}$ & 1958 & 62.5 & $\mathbf{S}$ & \\
\hline Perry & Murphysboro & Jacobson 1983 & 1983 & & & \\
\hline Piatt & Springfield & Treworgy and Bargh 1982 & 1978 & 62.5 & & \\
\hline Pike & Colchester & Reinertsen 1964 & 1964 & 125 & & \\
\hline Pope & Abbot Fm. & no mapped resources & & & S & \\
\hline Putman & Danville & Cady 1952 & 1950 & 62.5 & & \\
\hline Putman & Herrin & Treworgy and Bargh 1982 & 1978 & 62.5 & & \\
\hline Putman & Colchester & Cady 1952 & 1950 & 62.5 & & \\
\hline Randolph & Herrin & $\begin{array}{l}\text { Smith 1958, Treworgy and } \\
\text { Bargh } 1982\end{array}$ & 1958 & 125 & US & \\
\hline Randolph & Springfield & Smith 1958 & 1958 & 125 & $S$ & \\
\hline Richland & Calhoun & Nance and Treworgy 1981 & 1981 & 62.5 & & \\
\hline Richland & Danville & Work map by CGT & 1978 & 62.5 & & \\
\hline Richland & Herrin & This report & 1996 & 50 & & $\mathrm{C}$ \\
\hline Richland & Springfield & This report & 1996 & 50 & & $\mathrm{C}$ \\
\hline Richland & Seelyville & Treworgy 1981 & 1981 & 62.5 & & \\
\hline Rock Island & Rock Island & Searight and Smith 1969 & 1969 & 125 & & \\
\hline St. Clair & Herrin & Circulars 260, 527 & 1958 & 125 & US & \\
\hline Saline & Danville & Srith 1957 & 1957 & 125 & $\mathbf{S}$ & \\
\hline Saline & Herrin & $\begin{array}{l}\text { Smith 1957, Treworgy and } \\
\text { Bargh } 1982\end{array}$ & 1957 & 125 & US & $\mathbf{N}$ \\
\hline Saline & Springfield & $\begin{array}{l}\text { Smith 1957, Treworgy and } \\
\text { Bargh } 1982\end{array}$ & 1957 & 125 & US & $N$ \\
\hline Saline & Houchin Creek & Cady 1952 & 1950 & 62.5 & & \\
\hline Saline & Dekoven & Smith 1957, Jacobson 1993 & 1957 & 125 & $S$ & $\mathbf{N}$ \\
\hline Saline & Davis & Smith 1957, Jacobson 1993 & 1957 & 125 & $S$ & $N$ \\
\hline Sangamon & Herrin & Treworgy and Bargh 1982 & 1978 & 62.5 & & $\mathbf{N}$ \\
\hline Sangamon & Springfield & $\begin{array}{l}\text { Nance and Treworgy } 1981 \text {, } \\
\text { Tireworgy and Bargh } 1982\end{array}$ & 1978 & 62.5 & & $\mathbf{N}$ \\
\hline Sangamon & Houchin Creek & Cady 1952 & 1950 & 62.5 & & $\mathbf{N}$ \\
\hline Sangamon & Litchfield & Cadty 1952 & 1950 & 62.5 & & \\
\hline
\end{tabular}

$\uparrow$ Minor revisions made for this report 


\begin{tabular}{|c|c|c|c|c|c|c|}
\hline County & Seam & $\begin{array}{c}\text { Source } \\
\text { (ISGS publications) }\end{array}$ & $\begin{array}{l}\text { Map } \\
\text { year }\end{array}$ & $\begin{array}{c}\text { Scale } \\
(\times 1000)\end{array}$ & $\begin{array}{l}\text { Subsequent } \\
\text { mining }\end{array}$ & $\begin{array}{l}\text { Revi- } \\
\text { sion }^{\star *}\end{array}$ \\
\hline Schuyler & Springfield & Reinertsen 1964 & 1964 & 125 & & \\
\hline Schuyler & Colchester & Reinertsen 1964 & 1964 & 125 & $\mathrm{~S}$ & \\
\hline Scott & Herrin & Smith 1961 & 1961 & 125 & & $\mathbf{N}$ \\
\hline Scott & Colchester & Smith 1961, Cady 1952 & 1961 & 125 & & $N$ \\
\hline Shelby & Trowbridge & Nance and Treworgy 1981 & 1983 & 62.5 & & \\
\hline Shelby & Shelbyville & Nance and Treworgy 1981 & 1983 & 62.5 & & \\
\hline Shelby & Danville & Cady 1952 & 1950 & 62.5 & & \\
\hline Shelby & Herrin & This report & 1996 & 50 & & C \\
\hline Shelby & Springfield & Work map by CGT & 1978 & 62.5 & & \\
\hline Shelby & Seelyville & Treworgy 1981 & 1981 & 62.5 & & \\
\hline Shelby & Assumption & Cady 1952 & 1950 & 62.5 & & \\
\hline Stark & Danville & Smith and Berggren 1963 & 1963 & 125 & & $\mathbf{N}$ \\
\hline Stark & Herrin & $\begin{array}{l}\text { Cady } 1952, \text { Smith and Berg- } \\
\text { gren } 1963\end{array}$ & 1950 & 125 & $\mathrm{~S}$ & $N$ \\
\hline Stark & Colchester & Smith and Berggren 1963 & 1963 & 125 & & $N$ \\
\hline Tazewell & Danville & Smith and Berggren 1963 & 1963 & 125 & & \\
\hline Tazewell & Herrin & $\begin{array}{l}\text { Smith and Berggren 1963, } \\
\text { Treworgy and Bargh } 1982\end{array}$ & 1963 & 125 & & \\
\hline Tazewell & Springfield & $\begin{array}{l}\text { Smith and Berggren } 1963, \\
\text { Treworgy and Bargh } 1982\end{array}$ & 1964 & 125 & & \\
\hline Tazewell & Colchester & $\begin{array}{l}\text { Cady } 1952, \text { Smith and Berg- } \\
\text { gren } 1963\end{array}$ & 1950 & 125 & & \\
\hline Vermilion & Danville & Jacobson and Bengal 1981 & 1981 & 62.5 & $\mathrm{U}$ & \\
\hline Vermilion & Herrin & Jacobson and Bengal 1981 & 1981 & 62.5 & US & $N$ \\
\hline Vermilion & Seelyville & Cady 1952 & 1950 & 62.5 & & \\
\hline Wabash & Friendsville & Nance and Treworgy 1981 & 1983 & 62.5 & & $N$ \\
\hline Wabash & Herrin & Treworgy and Bargh 1982 & 1978 & 62.5 & & \\
\hline Wabash & Springfield & Treworgy and Bargh 1982 & 1978 & 62.5 & $\mathrm{U}$ & $\mathbf{N}$ \\
\hline Warren & Springfield & Smith and Berggren 1963 & 1963 & 125 & & \\
\hline Warren & Colchester & Smith and Berggren 1963 & 1963 & 125 & & \\
\hline Warren & Rock Island & Searight and Smith 1969 & 1969 & 125 & & \\
\hline Washington & Herrin & Treworgy and Bargh 1982 & 1978 & 62.5 & $\mathrm{U}$ & \\
\hline Wayne & Herrin & Treworgy and Bargh 1982 & 1978 & 62.5 & & \\
\hline Wayne & Springfield & $\begin{array}{l}\text { Treworgy and Bargh } 1982 \text {, } \\
\text { work map by CGT }\end{array}$ & 1978 & 62.5 & & \\
\hline White & Herrin & This report & 1996 & 50 & $\mathrm{U}$ & $\mathrm{C}$ \\
\hline White & Springfield & This report & 1996 & 50 & & $\mathrm{C}$ \\
\hline White & Dekoven & Cady 1952 & 1950 & 62.5 & & \\
\hline White & Davis & Cady 1952 & 1950 & 62.5 & & \\
\hline Will & Colchester & Smith 1968 & 1968 & 125 & $S$ & \\
\hline Williamson & Miscellaneous & Cady 1952, Smith 1957 & 1950 & 125 & $\mathrm{~S}$ & \\
\hline Williamson & Danville & Smith 1957 & 1957 & 125 & $\mathrm{~S}$ & $N$ \\
\hline Williamson & Herrin & $\begin{array}{l}\text { Smith 1957, Treworgy and } \\
\text { Bargh } 1982\end{array}$ & 1957 & 125 & US & $N$ \\
\hline Williamson & Springfield & $\begin{array}{l}\text { Smith 1957, Treworgy and } \\
\text { Bargh } 1982\end{array}$ & 1957 & 125 & $\mathrm{~S}$ & \\
\hline Williamson & Dekoven & Cady 1952, Smith 1957 & 1950 & 125 & & \\
\hline Williamson & Davis & Cady 1952, Smith 1957 & 1950 & 125 & & \\
\hline Woodford & Danville & Cady 1952 & 1950 & 62.5 & & \\
\hline Woodford & Springfield & Cady 1952 & 1950 & 62.5 & & \\
\hline Woodford & Colchester & Cady 1952 & 1950 & 62.5 & & \\
\hline
\end{tabular}


APPENDIX 2 Assumptions used to allocate reported mine production to individual seams

\begin{tabular}{|c|c|}
\hline Coals reported mined & Assumptions \\
\hline Herrin and Springfield & $\begin{array}{l}\text { Allocate production } 60 / 40 \text {, except in Randolph County allocate } \\
40 / 60 \text {. }\end{array}$ \\
\hline Davis-Dekoven & Allocate production $50 / 50$. \\
\hline Nos. 2 and 3 & $\begin{array}{l}\text { Assume to be Davis and Dekoven; allocate production equally } \\
\text { between seams. }\end{array}$ \\
\hline Nos. 2 and 7 (Kankakee Co.) & $\begin{array}{l}\text { No resources of Danville (No. 7) have been mapped and the } \\
\text { coal is not known to be present; not sure which seam this } \\
\text { might refer to. Allocate all production to Colchester (No. 2). }\end{array}$ \\
\hline Nos. 2 and 5 (Fulton Co.) & $\begin{array}{l}\text { Allocate } 75 \% \text { to Colchester, } 25 \% \text { to Springfield (No. 5) based } \\
\text { on following year's production of Colchester only. }\end{array}$ \\
\hline Nos. 5, 5A, and 6 (Gallatin Co.) & $\begin{array}{l}\text { Allocate equally between Herrin and Springfield; no resources } \\
\text { of Briar Hill (No. } 5 a \text { ) mapped. }\end{array}$ \\
\hline Nos. 5 and $5 \mathrm{~A}$ & $\begin{array}{l}\text { Based on thickness and assumption that Briar Hill is not } \\
\text { always present; allocate } 20 \% \text { to Briar Hill, } 80 \% \text { to Springfield. }\end{array}$ \\
\hline Nos. 5, 6, and 7(Perry Co.) & $\begin{array}{l}\text { Danville production assumed to be minimal. Allocate } \\
\text { production } 60 \% \text { to Herrin, } 40 \% \text { to Springfield. }\end{array}$ \\
\hline Nos. 6 and 7 (Delta Mine) & $\begin{array}{l}\text { Danville production assumed to be minimal. Danville is } 25 \% \text { of } \\
\text { total thickness, but not consistently present. Allocate } 90 \% \text { to } \\
\text { Herrin, } 10 \% \text { to Danville. }\end{array}$ \\
\hline Nos. 4 and 5 (Williamson Co.) & $\begin{array}{l}\text { Allocate } 20 \% \text { to Houchin Creek (No. } 4 \text { ), } 80 \% \text { to Springfield } \\
\text { based on average thickness and assumption that Houchin } \\
\text { Creek was not mined in all areas of pit. }\end{array}$ \\
\hline Nos. $3,4,5,5 \mathrm{~A}$, and 6 (Gallatin Co.) & $\begin{array}{l}\text { Allocate } 10 \% \text { to Briar Hill, } 20 \% \text { to Davis, Dekoven, Springfield, } \\
\text { and Herrin. }\end{array}$ \\
\hline Nos. $3,4,5$, and 6 (Gallatin Co.) & Allocate $25 \%$ to each. \\
\hline Nos. 3 and 4 & Assume to be Davis and Dekoven; allocate 50/50. \\
\hline
\end{tabular}


APPENDIX 3 Factors used to calculate underground-minable reserves restricted by land use The tonnage of underground-minable demonstrated reserves not restricted by land use was calculated with different accessibility factors for each county and each seam within a county. An accessibility factor of $94 \%$ was used for all surface-minable reserves.

\begin{tabular}{|c|c|c|c|c|c|}
\hline County & Coal & $\%$ accessible & County & Coal & $\%$ accessible \\
\hline Bond & Herrin & 94 & Fulton & Springfield & 100 \\
\hline Bond & Colchester & 100 & Fulton & Colchester & 100 \\
\hline Bond & Litchfield & 100 & Fulton & Rock Island' & 94 \\
\hline Bureau & Danville & 85 & Gallatin & Herrin & 86 \\
\hline Bureau & Herrin & 90 & Gallatin & Springfield & 87 \\
\hline Bureau & Colchester & 94 & Gallatin & Survant & 100 \\
\hline Champaign & Danville & 94 & Gallatin & Dekoven & 94 \\
\hline Champaign & Herrin & 95 & Gallatin & Davis & 94 \\
\hline Christian & Danville & 82 & Greene & Colchester & 100 \\
\hline Christian & Herrin & 95 & Grundy & Colchester & 97 \\
\hline Christian & Springfield & 92 & Hamilton & Herrin & 88 \\
\hline Christian & Rock Island & 93 & Hamilton & Springfield & 84 \\
\hline Clark & Danville & 94 & Hamilton & Dekoven & 100 \\
\hline Clark & Jamestown & 95 & Hamilton & Davis & 100 \\
\hline Clark & Herrin & 67 & Henry & Colchester & 100 \\
\hline Clark & Springfield & 92 & Jackson & Springfield & 97 \\
\hline Clark & Seelyville & 93 & Jasper & Danville & 98 \\
\hline Clay & Herrin & 81 & Jasper & Herrin & 90 \\
\hline Clay & Springfield & 82 & Jasper & Springfield & 91 \\
\hline Clay & Seelyville & 81 & Jasper & Seelyville & 92 \\
\hline Clinton & Herrin & 83 & Jefferson & Herrin & 89 \\
\hline Coles & Danville & 76 & Jefferson & Springfield & 90 \\
\hline Coles & Herrin & 75 & Jersey & Colchester & 100 \\
\hline Coles & Springfield & 89 & Kankakee & Colchester & 100 \\
\hline Coles & Seelyville & 87 & Knox & Colchester & 100 \\
\hline Crawford & Danville & 58 & Knox & Rock Island & 100 \\
\hline Crawford & Jamestown & 66 & La Salle & Danville & 87 \\
\hline Crawford & Herrin & 52 & La Salle & Herrin & 73 \\
\hline Crawford & Springfield & 63 & La Salle & Colchester & 91 \\
\hline Crawford & Seelyville & 62 & Lawrence & Danville & 86 \\
\hline Cumberland & Danville & 97 & Lawrence & Jamestown & 81 \\
\hline Cumberland & Herrin & 94 & Lawrence & Herrin & 84 \\
\hline Cumberland & Springfield & 95 & Lawrence & Springfield & 83 \\
\hline Cumberland & Seelyville & 93 & Lawrence & Survant & 87 \\
\hline De Witt & Springfield & 90 & Lawrence & Seelyville & 88 \\
\hline Douglas & Herrin & 94 & Livingston & Danville & 95 \\
\hline Douglas & Springfield & 96 & Livingston & Herrin & 98 \\
\hline Edgar & Danville & 96 & Livingston & Houchin Creek & 94 \\
\hline Edgar & Herrin & 92 & Livingston & Colchester & 96 \\
\hline Edgar & Springfield & 97 & Logan & Herrin & 91 \\
\hline Edgar & Seelyville & 95 & Logan & Springfield & 96 \\
\hline Edwards & Herrin & 87 & McLean & Danville & 82 \\
\hline Edwards & Springfield & 85 & McLean & Springfield & 92 \\
\hline Effingham & Danville & 95 & McLean & Colchester & 59 \\
\hline Effingham & Herrin & 91 & Macon & Herrin & 93 \\
\hline Effingham & Springfield & 92 & Macon & Springfield & 81 \\
\hline Effingham & Seelyville & 93 & Macoupin & Danville & 93 \\
\hline Fayette & Danville & 94 & Macoupin & Herrin & 96 \\
\hline Fayette & Herrin & 92 & Macoupin & Houchin Creek & 100 \\
\hline Fayette & Springfield & 90 & Macoupin & Colchester & 96 \\
\hline Franklin & Herrin & 87 & Macoupin & Wiley & 82 \\
\hline Franklin & Springfield & 85 & Macoupin & Litchfield & 91 \\
\hline Franklin & Mt. Rorah & 92 & Madison & Herrin & 85 \\
\hline Franklin & Dekoven & 79 & Madison & Colchester & 99 \\
\hline Franklin & Davis & 78 & Madison & Wiley & 98 \\
\hline \multirow[t]{2}{*}{ Fulton } & Herrin & 94 & Madison & Litchfield & 97 \\
\hline & & continued & & & continued \\
\hline
\end{tabular}


APPENDIX 3 continued

\begin{tabular}{|c|c|c|}
\hline County & Coal & $\%$ accessible \\
\hline Marion & Herrin & 87 \\
\hline Marion & Springfield & 84 \\
\hline Marshall & Danville & 97 \\
\hline Marshall & Herrin & 63 \\
\hline Marshall & Colchester & 95 \\
\hline Menard & Springfield & 95 \\
\hline Montgomery & Danville & 95 \\
\hline Montgomery & Herrin & 96 \\
\hline Montgomery & Houchin Creek & 97 \\
\hline Montgomery & Colchester & 94 \\
\hline Montgomery & Wiley & 83 \\
\hline Montgomery & Litchfield & 91 \\
\hline Morgan & Herrin & 98 \\
\hline Morgan & Colchester & 91 \\
\hline Moultrie & Herrin & 85 \\
\hline Peoria & Springfield & 100 \\
\hline Peoria & Colchester & 100 \\
\hline Perry & Herrin & 97 \\
\hline Perry & Springfield & 93 \\
\hline Perry & Murphysboro & 100 \\
\hline Piatt & Springfield & 95 \\
\hline Putnam & Danville & 94 \\
\hline Putnam & Herrin & 86 \\
\hline Putnam & Colchester & 95 \\
\hline Randolph & Herrin & 90 \\
\hline Randolph & Springfield & 94 \\
\hline Richland & Danville & 88 \\
\hline Richland & Herrin & 87 \\
\hline Richland & Springfield & 88 \\
\hline Richland & Seelyville & 100 \\
\hline St. Clair & Herrin & 86 \\
\hline Saline & Herrin & 87 \\
\hline Saline & Springfield & 87 \\
\hline Saline & Survant & 94 \\
\hline Saline & Dekoven & 86 \\
\hline Saline & Davis & 86 \\
\hline Sangamon & Herrin & 88 \\
\hline Sangamon & Springfield & 87 \\
\hline Sangamon & Houchin Creek & 91 \\
\hline Sangamon & Litchfield & 42 \\
\hline Scott & Colchester & 100 \\
\hline Shelby & Danville & 98 \\
\hline Shelby & Herrin & 95 \\
\hline Shelby & Springfield & 97 \\
\hline Shelby & Seelyville & 95 \\
\hline Shelby & Assumption & 100 \\
\hline Stark & Herrin & 100 \\
\hline Tazewell & Herrin & 80 \\
\hline Tazewell & Springfield & 86 \\
\hline Tazewell & Colchester & 52 \\
\hline Vermilion & Danville & 97 \\
\hline Vermilion & Herrin & 94 \\
\hline Vermilion & Seelyville & 61 \\
\hline Wabash & Herrin & 66 \\
\hline Wabash & Springfield & 62 \\
\hline Washington & Herrin & 94 \\
\hline Wayne & Herrin & 79 \\
\hline
\end{tabular}

\begin{tabular}{lll}
\hline County & Coal & \% accessible \\
\hline Wayne & Springfield & 80 \\
White & Herrin & 81 \\
White & Springfield & 80 \\
White & Dekoven & 72 \\
White & Davis & 66 \\
Williamson & Herrin & 95 \\
Williamson & Springfield & 89 \\
Williamson & Survant & 68 \\
Williamson & Mt. Rorah & 82 \\
Williamson & Dekoven & 88 \\
Williamson & Davis & 88 \\
Williamson & Wise Ridge & 94 \\
Woodford & Danville & 92 \\
Woodford & Springfield & 91 \\
Woodford & Colchester & 96 \\
\end{tabular}


Appendix 4 Remaining demonstrated reserve base in llinois, January 1, 1996 (million short tons)

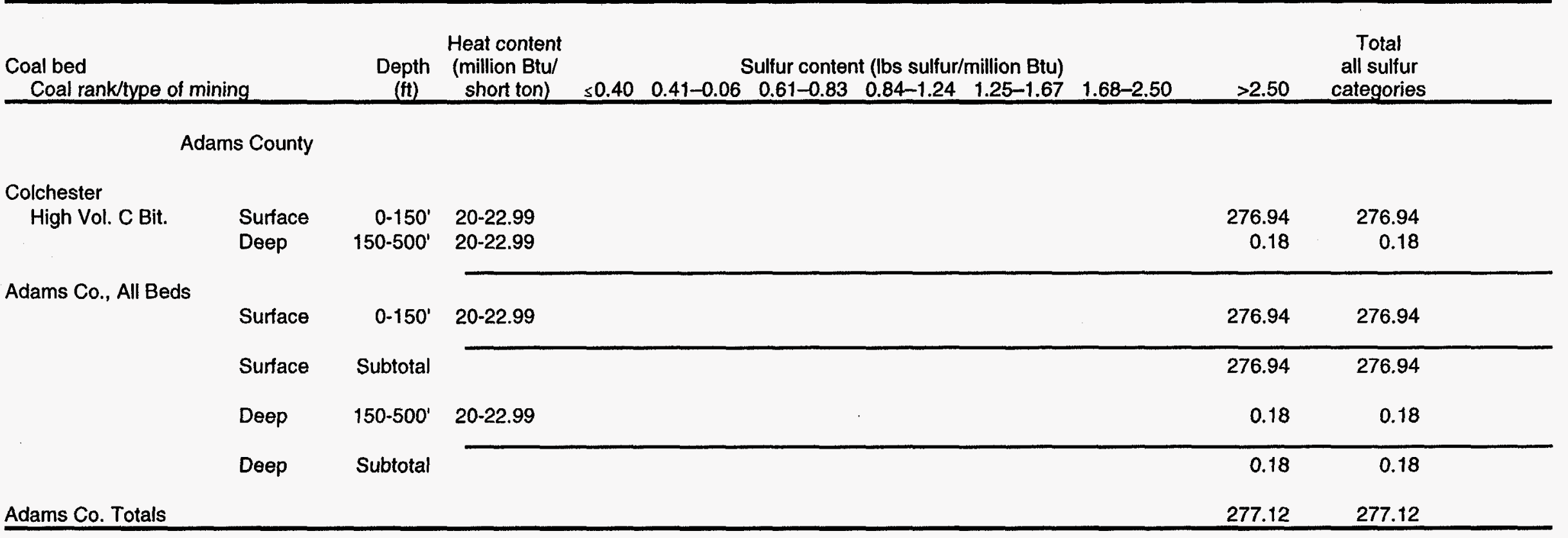

Bond County

Herrin

High Vol. C Bit.

$150-500^{\prime} \quad 20-22.99$

$2,251.62$

$2,251.62$

500-1000' 20-22.99

$51.60 \quad 51.60$

Bond Co., All Beds

(20-209

Deep

$150-500^{\prime} \quad 20-22.99$

$500-1000^{\prime} \quad 20-22.99$

Deep Subtotal

$2,303.22 \quad 2,303.22$

Bond Co. Totals

$2,303.22 \quad 2,303.22$


Appendix 4 Remaining demonstrated reserve base in Illinois, January 1, 1996 (million short tons)

$\stackrel{8}{0}$

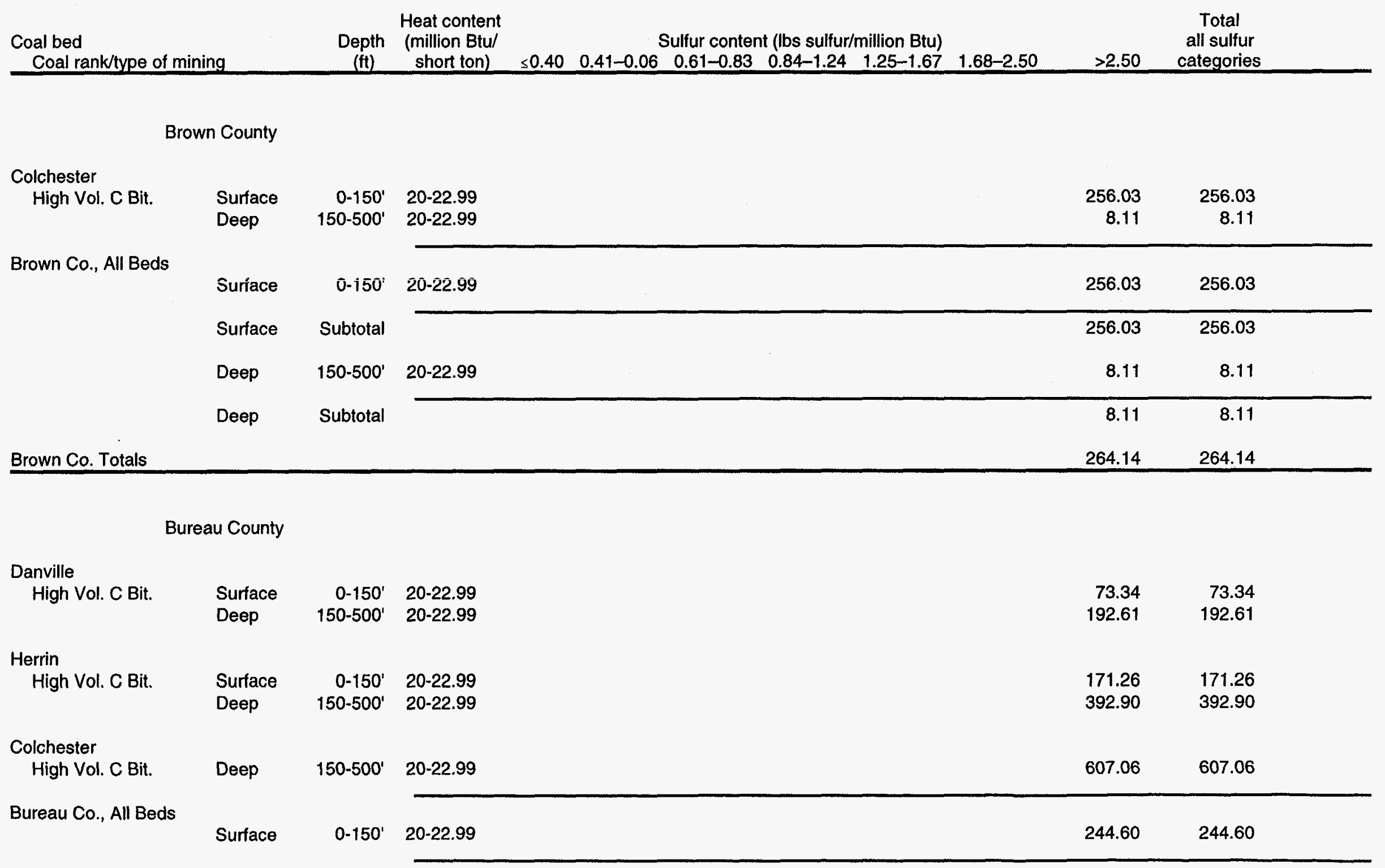


Appendix 4 Remaining demonstrated reserve base in Illinois, January 1, 1996 (million short tons)

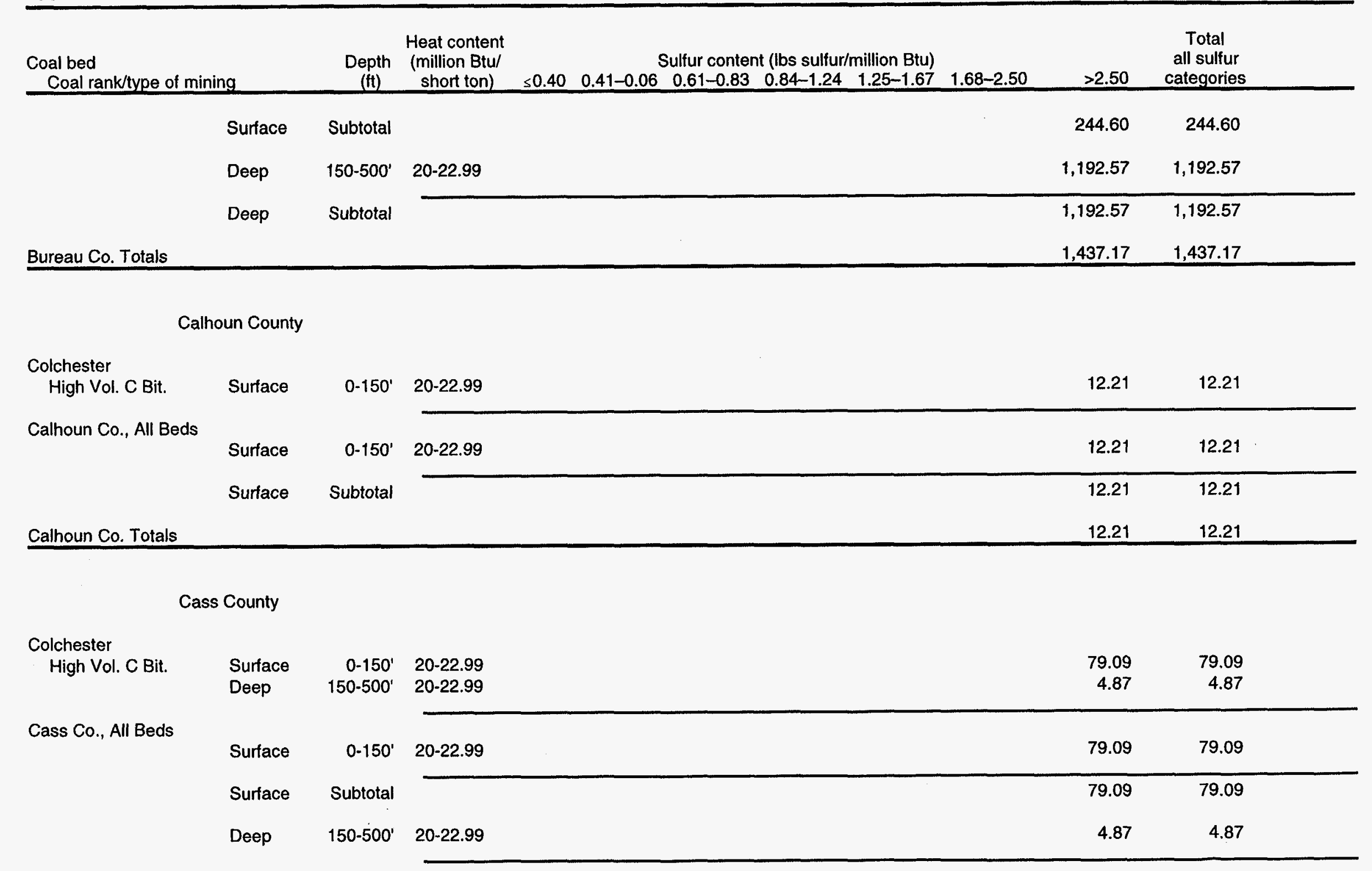


Appendix 4 Remaining demonstrated reserve base in Illinois, January 1, 1996 (million short tons)

or

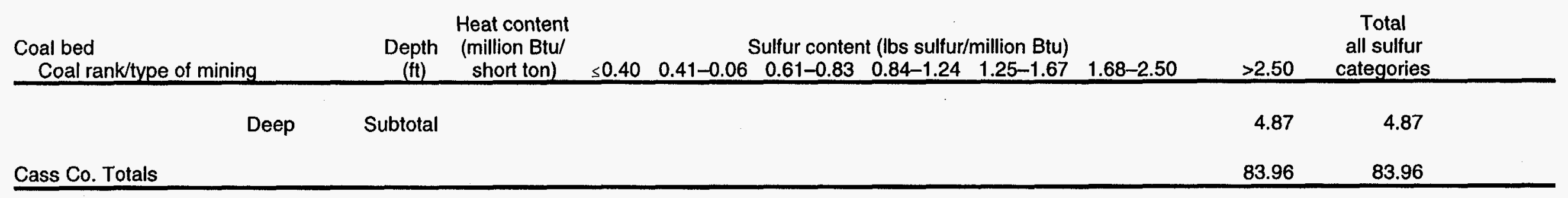

\section{Champaign County}

Danville

$\begin{array}{lll}\text { High Vol. C Bit. } \quad \text { Deep } \quad 150-500^{\prime} \quad 20-22.99 & 37.00\end{array}$

Herrin

$\begin{array}{llll}\text { High Vol. C Bit. } \quad \text { Deep } & 150-500^{\prime} & 20-22.99 & 19.09\end{array}$

Champaign Co., All Beds

Champaign Co., All Beds Deep
Deep
Champaign Co. Totals
Christian County

\section{Danville}

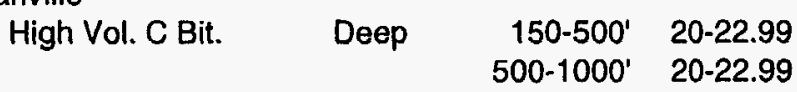

$150-500^{\prime} \quad 20-22.99$

19.09

$171.85 \quad 190.94$

Subtotal

19.09

171.85

190.94

Herrin

High Vol. C Bit. Deep 150-500' 20-22.99

$\begin{array}{lrr}150-500^{\prime} & 20-22.99 \\ 500-1000^{\prime} & 20-22.99\end{array}$

19.09

171.85

190.94

Springfield

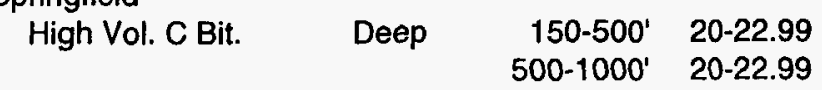

$\begin{array}{llllll}107.88 & 43.56 & 35.44 & 141.87 & 1,663.19 & 1,991.93\end{array}$

$\begin{array}{ll}16.88 & 16.88 \\ 44.46 & 44.46\end{array}$

$\begin{array}{llrrr}12.55 & 10.62 & 85.94 & 723.01 & 832.12\end{array}$

$495.38 \quad 495.38$

$113.80 \quad 113.80$


Appendix 4 Remaining demonstrated reserve base in Illinois, January 1, 1996 (million short tons)

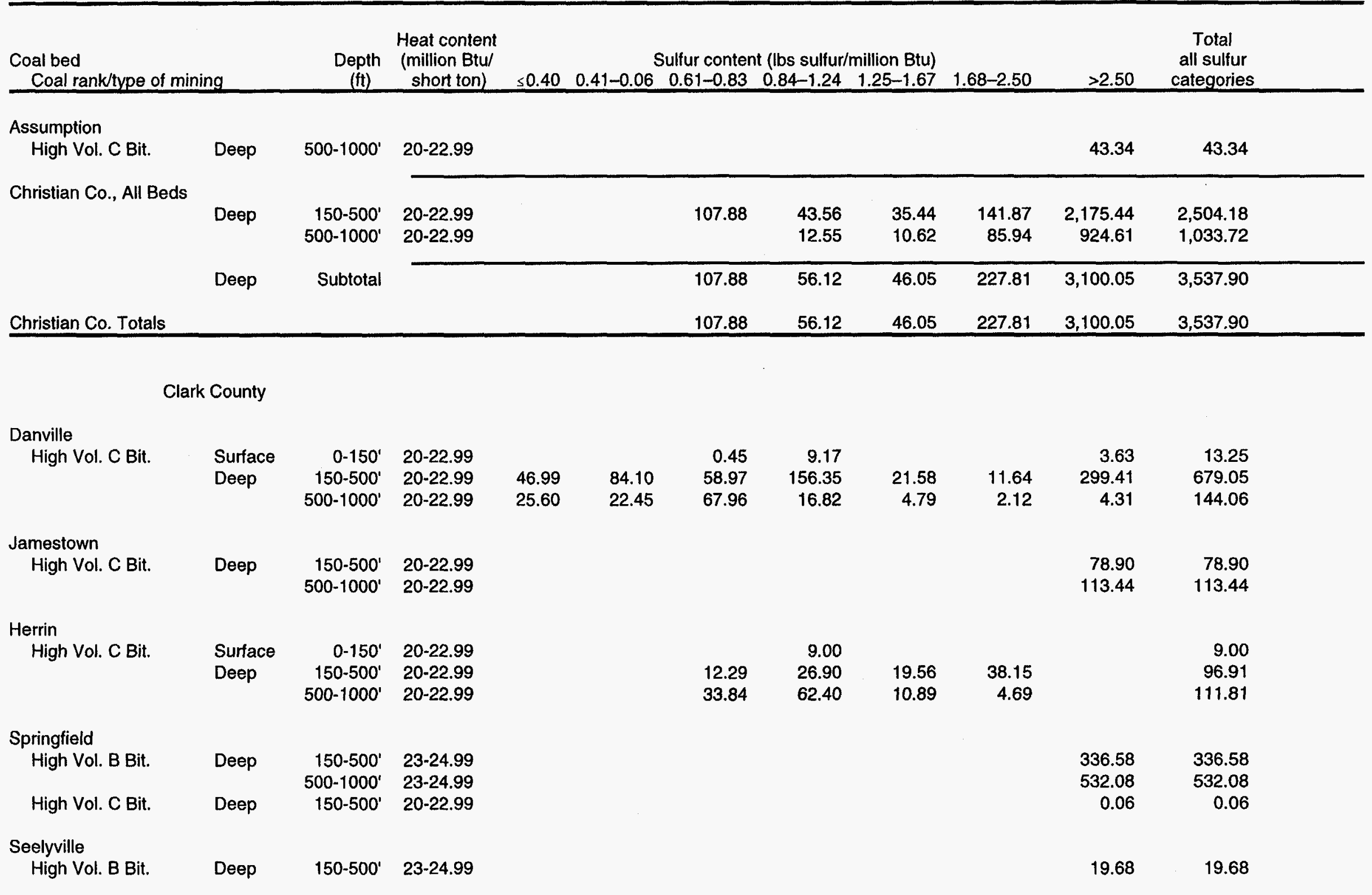


Appendix 4 Remaining demonstrated reserve base in Illinois, January 1, 1996 (million short tons)

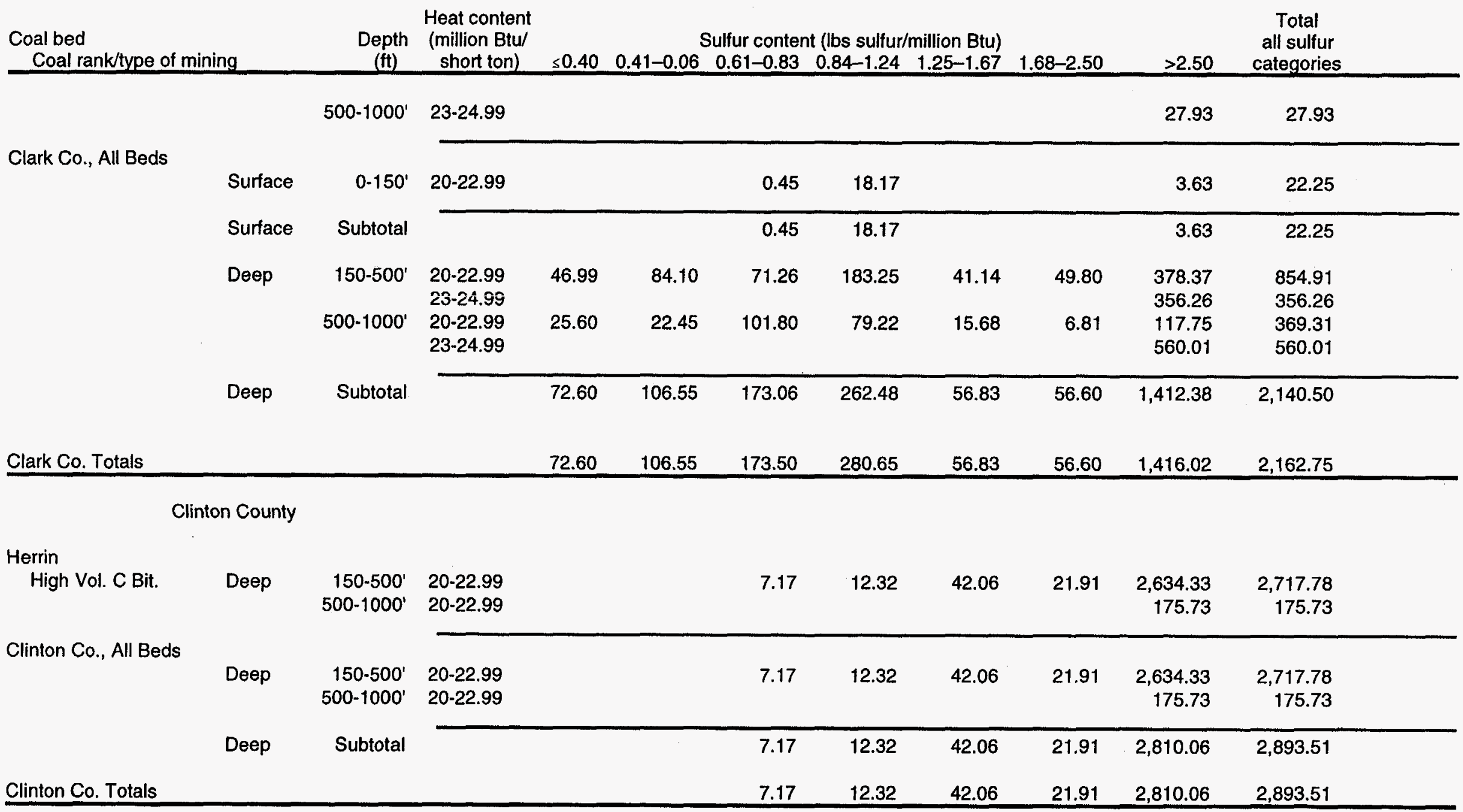


Appendix 4 Remaining demonstrated reserve base in Illinois, January 1, 1996 (million short tons)

\begin{tabular}{|c|c|c|c|c|c|c|c|c|c|c|c|}
\hline \multicolumn{2}{|c|}{$\begin{array}{l}\text { Coal bed } \\
\text { Coal rank/type of mining }\end{array}$} & \multirow[t]{2}{*}{$\begin{array}{l}\text { Depth } \\
(\mathrm{ft})\end{array}$} & \multirow[t]{2}{*}{$\begin{array}{l}\text { Heat content } \\
\text { (million Btu/ } \\
\text { short ton) }\end{array}$} & \multicolumn{6}{|c|}{ Sulfur content (lbs sulfur/million Btu) } & \multicolumn{2}{|r|}{$\begin{array}{c}\text { Total } \\
\text { all sulfur } \\
\text { categories } \\
\end{array}$} \\
\hline \multicolumn{10}{|c|}{ Coles County } & & \\
\hline \multicolumn{12}{|l|}{ Danville } \\
\hline \multirow[t]{4}{*}{ High Vol. C Bit. } & Surface & $0-150^{\prime}$ & $20-22.99$ & & & 3.72 & 3.34 & & & & 7.06 \\
\hline & Deep & $150-500^{\prime}$ & 20-22.99 & & & & & & & & \\
\hline & & $500-1000^{\prime}$ & 20-22.99 & & & 12.15 & 5.40 & 5.00 & 4.02 & 169.34 & 195.90 \\
\hline & & $>1000^{\prime}$ & 20-22.99 & & & 9.87 & 14.03 & 7.54 & 1.46 & 7.47 & 40.38 \\
\hline \multicolumn{12}{|l|}{ Herrin } \\
\hline \multirow[t]{4}{*}{ High Vol. C Bit. } & Surface & $0-150^{\prime}$ & $20-22.99$ & & & & & 4.32 & 1.46 & & 5.77 \\
\hline & Deep & $150-500^{\prime}$ & $20-22.99$ & & & & 2.65 & 74.63 & 33.34 & & 110.61 \\
\hline & & $500-1000^{\prime}$ & $20-22.99$ & & & & 32.08 & 5.06 & 3.31 & & 40.45 \\
\hline & & $>1000^{\prime}$ & $20-22.99$ & & & 43.71 & 99.81 & 9.20 & 23.56 & & 176.27 \\
\hline \multicolumn{12}{|l|}{ Springfield } \\
\hline \multirow[t]{2}{*}{ High Vol. B Bit. } & Deep & $500-1000^{\prime}$ & $23-24.99$ & & & & & & & 11.82 & 11.82 \\
\hline & & $>1000^{\prime}$ & $23-24.99$ & & & & & & & 210.56 & 210.56 \\
\hline \multirow[t]{4}{*}{ High Vol. C Bit. } & Surface & $0-150^{\prime}$ & $20-22.99$ & & & & & & & 0.91 & 0.91 \\
\hline & Deep & $150-500^{\prime}$ & $20-22.99$ & & & & & & & 11.91 & 11.91 \\
\hline & & $500-1000^{\prime}$ & $20-22.99$ & & & & & & & 20.94 & 20.94 \\
\hline & & $>1000^{\prime}$ & $20-22.99$ & & & & & & & 5.03 & 5.03 \\
\hline \multirow[t]{8}{*}{ Coles Co., All Beds } & & & & & & & & & & & \\
\hline & Surface & $0-150^{\prime}$ & $20-22.99$ & & & 3.72 & 3.34 & 4.32 & 1.46 & 0.91 & 13.74 \\
\hline & Surface & Subtotal & & & & 3.72 & 3.34 & 4.32 & 1.46 & 0.91 & 13.74 \\
\hline & Deep & $150-500^{\prime}$ & $20-22.99$ & & & & 2.65 & 74.63 & 33.34 & 11.91 & 122.53 \\
\hline & & $500-1000^{\prime}$ & $20-22.99$ & & & 12.15 & 37.47 & 10.06 & 7.33 & 190.27 & 257.28 \\
\hline & & & 23-24.99 & & & & & & & 11.82 & 11.82 \\
\hline & & $>1000^{\prime}$ & $20-22.99$ & & & 53.58 & 113.84 & 16.73 & 25.03 & 12.50 & 221.68 \\
\hline & & & $23-24.99$ & & & & & & & 210.56 & 210.56 \\
\hline Coles Co. Totals & Deep & Subtotal & & & & $\begin{array}{l}65.73 \\
69.45 \\
\end{array}$ & $\begin{array}{l}153.96 \\
157.31 \\
\end{array}$ & $\begin{array}{l}101.42 \\
105.73\end{array}$ & $\begin{array}{l}65.70 \\
67.15 \\
\end{array}$ & $\begin{array}{l}437.06 \\
437.96 \\
\end{array}$ & $\begin{array}{l}823.87 \\
837.61 \\
\end{array}$ \\
\hline
\end{tabular}


Appendix 4 Remaining demonstrated reserve base in Illinois, January 1, 1996 (million short tons)

G

\begin{tabular}{|c|c|c|c|c|c|c|c|c|c|c|c|}
\hline \multicolumn{2}{|c|}{$\begin{array}{l}\text { Coal bed } \\
\text { Coal rank/type of mining }\end{array}$} & $\begin{array}{l}\text { Depth } \\
\text { (ft) }\end{array}$ & $\begin{array}{c}\text { Heat content } \\
\text { (million Btu/ } \\
\text { short ton) }\end{array}$ & \multicolumn{6}{|c|}{ Sulfur content (Ibs sulfur/million Btu) } & \multicolumn{2}{|r|}{$\begin{array}{c}\text { Total } \\
\text { all sulfur } \\
\text { categories }\end{array}$} \\
\hline \multicolumn{12}{|c|}{ Crawford County } \\
\hline \multicolumn{12}{|l|}{ Bristol Hill } \\
\hline High Vol. B Bit. & Surface & $0-150^{\prime}$ & $23-24.99$ & & & & & & 17.98 & & 17.98 \\
\hline \multicolumn{12}{|l|}{ Danville } \\
\hline \multirow{2}{*}{ High Vol. B Bit. } & Deep & $150-500^{\prime}$ & 23-24.99 & & 5.08 & 56.83 & 48.97 & 20.44 & 2.49 & 2.07 & 135.88 \\
\hline & & $500-1000^{\prime}$ & $23-24.99$ & 2.42 & 19.11 & 20.48 & & & & & 42.01 \\
\hline \multirow[t]{2}{*}{ Hight Vout. C Bit. } & Deep & $150-500^{\prime}$ & $20-22.99$ & 119.50 & 122.86 & 13.31 & & & & & 255.67 \\
\hline & & $500-1000^{\prime}$ & $20-22.99$ & 7.32 & 0.96 & 0.30 & & & & & 8.58 \\
\hline \multicolumn{12}{|l|}{ Jamestown } \\
\hline \multirow[t]{2}{*}{ High Vol. B Bit. } & Deep & $150-500^{\prime}$ & 23-24.99 & & & & & & & 59.83 & 59.83 \\
\hline & & $500-1000^{\prime}$ & $23-24.99$ & & & & & & & 126.20 & 126.20 \\
\hline \multirow[t]{2}{*}{ High Vol. C Bit. } & Deep & $150-500^{\prime}$ & $20-22.99$ & & & & & & & 294.19 & 294.19 \\
\hline & & $500-1000^{\prime}$ & $20-22.99$ & & & & & & & 88.20 & 88.20 \\
\hline \multicolumn{12}{|l|}{ Herrin } \\
\hline \multirow[t]{2}{*}{ High Vol. B Bit. } & Deep & $150-500^{\prime}$ & 23-24.99 & & & & & & & 11.93 & 11.93 \\
\hline & & $500-1000^{\prime}$ & 23-24.99 & & & & & & 0.04 & 18.99 & 19.03 \\
\hline \multirow[t]{2}{*}{ High Vol. C Bit. } & Deep & $150-500^{\prime}$ & $20-22.99$ & & & & & 0.68 & 6.94 & & 7.62 \\
\hline & & $500-1000^{\prime}$ & $20-22.99$ & & & & 0.32 & 0.33 & 1.03 & & 1.68 \\
\hline \multicolumn{12}{|l|}{ Springfield } \\
\hline \multirow[t]{2}{*}{ High Vol. B Bit. } & Deep & $150-500^{\prime}$ & $23-24.99$ & & & & & & & 87.65 & 87.65 \\
\hline & & $500-1000^{\prime}$ & $23-24.99$ & & & & & & & 331.37 & 331.37 \\
\hline \multicolumn{12}{|l|}{ Seelyville } \\
\hline High Vol. B Bit. & Deep & $500-1000^{\prime}$ & $23-24.99$ & & & & & & & 210.60 & 210.60 \\
\hline \multicolumn{12}{|c|}{ Crawford Co., All Beds } \\
\hline & Surface & $0-150^{\prime}$ & $23-24.99$ & & & & & & 17.98 & & 17.98 \\
\hline & Surface & Subtotal & & & & & & & 17.98 & & 17.98 \\
\hline
\end{tabular}


Appendix 4 Remaining demonstrated reserve base in Illinois, January 1, 1996 (million short tons)

\begin{tabular}{|c|c|c|c|c|c|c|c|c|c|c|}
\hline $\begin{array}{l}\text { Coal bed } \\
\text { Coal rank/type of mining }\end{array}$ & $\begin{array}{l}\text { Depth } \\
\text { (ft) }\end{array}$ & $\begin{array}{l}\text { Heat content } \\
\text { (million Btu/ } \\
\text { short ton) }\end{array}$ & \multicolumn{6}{|c|}{ Sulfur content (lbs sulfur/million Btu) } & \multicolumn{2}{|r|}{$\begin{array}{c}\text { Total } \\
\text { all sulfur } \\
\text { categories }\end{array}$} \\
\hline Deep & $150-500^{\prime}$ & $20-22.99$ & 119.50 & 122.86 & 13.31 & & 0.68 & 6.94 & 294.19 & 557.47 \\
\hline & & $23-24.99$ & & 5.08 & 56.83 & 48.97 & 20.44 & 2.49 & 161.47 & 295.28 \\
\hline & $500-1000^{\prime}$ & $20-22.99$ & 7.32 & 0.96 & 0.30 & 0.32 & 0.33 & 1.03 & 88.20 & 98.47 \\
\hline & & 23-24.99 & 2.42 & 19.11 & 20.48 & & & 0.04 & 687.16 & 729.21 \\
\hline Deep & Subtotal & & 129.24 & 148.02 & 90.92 & 49.29 & 21.45 & 10.50 & $1,231.02$ & $1,680.44$ \\
\hline Crawford Co. Totals & & & 129.24 & 148.02 & 90.92 & 49.29 & 21.45 & 28.48 & $1,231.02$ & $1,698.42$ \\
\hline
\end{tabular}

Cumberland County

Trowbridge

High Vol. C Bit. Surface $0-150^{\prime}$

Danville

High Vol. B Bit. Deep $\quad 500-1000^{\prime} \quad 23-24.99$

$\quad>1000^{\prime} \quad 23-24.99$

High Vol. C Bit. Deep $\quad 150-500^{\prime} \quad 20-22.99$

$500-1000^{\prime} \quad 20-22.99$

$>1000^{\prime} \quad 20-22.99$

Herrin

High Vol. B Bit. Deep $\quad 500-1000^{\prime} \quad 23-24.99$

$>1000^{\prime} \quad 23-24.99$

High Vol. C Bit. Deep 150-500' $20-22.99$

$500-1000^{\prime} \quad 20-22.99$

$>1000^{\prime} \quad 20-22.99$

$\begin{array}{rrr}0.02 & 6.51 & 20.53 \\ 6.01 & 1.69 \\ 94.71 & 17.61 \\ 121.96 & 228.43\end{array}$

0.28

0.28

Springfield

High Vol. B Bit. Deep $\begin{array}{rr}150-500^{\prime} & 23-24.99 \\ 500-1000^{\prime} & 23-24.99\end{array}$

$\begin{array}{rr}49.45 & 49.45 \\ 267.81 & 267.81 \\ 5.28 & 5.28 \\ 120.34 & 120.34 \\ 36.61 & 36.61\end{array}$

$\begin{array}{rrrrr} & & & 1.24 & 1.24 \\ 46.47 & 14.81 & 12.00 & 426.01 & 526.34 \\ 7.09 & & & & 14.80 \\ 54.23 & 1.52 & 0.79 & 6.38 & 175.24 \\ 26.92 & 7.90 & 6.25 & 35.25 & 426.71\end{array}$

$\begin{array}{rr}1.59 & 1.59 \\ 94.08 & 94.08 \\ 738.81 & 738.81\end{array}$


Appendix 4 Remaining demonstrated reserve base in Illinois, January 1, 1996 (million short tons)

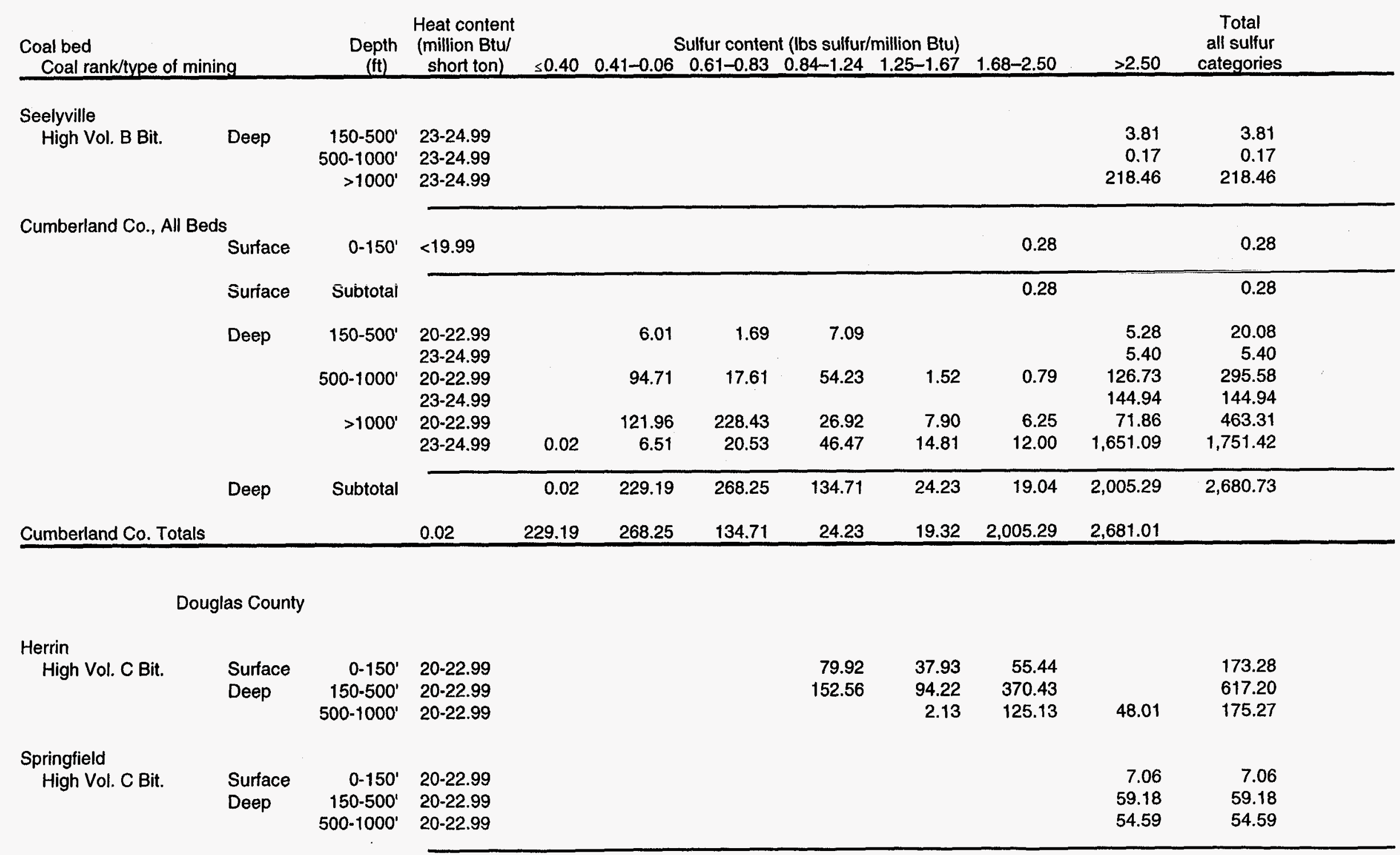


Appendix 4 Remaining demonstrated reserve base in Illinois, January 1, 1996 (million short tons)

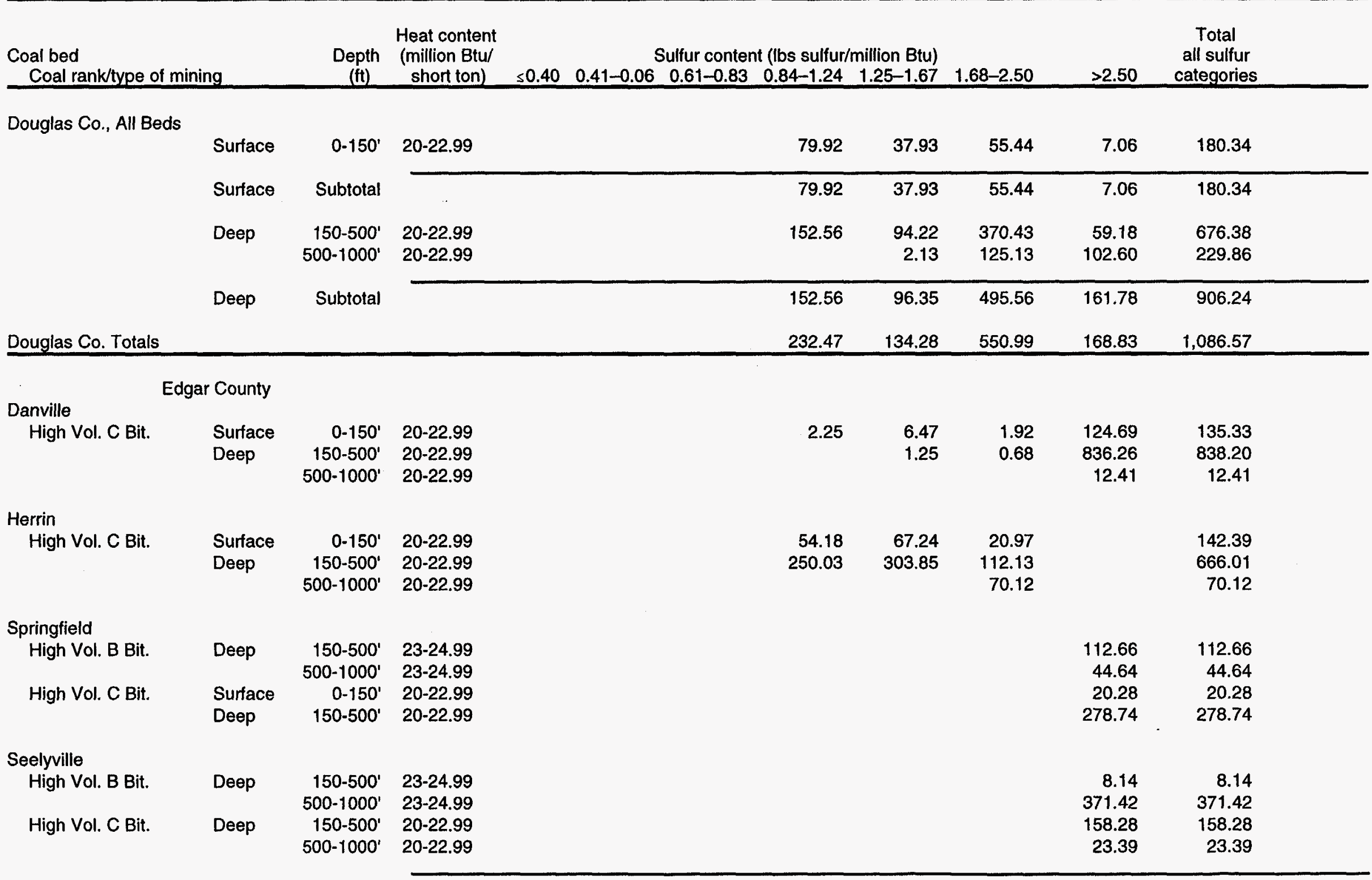


Appendix 4 Remaining demonstrated reserve base in lllinois, January 1, 1996 (million short tons)

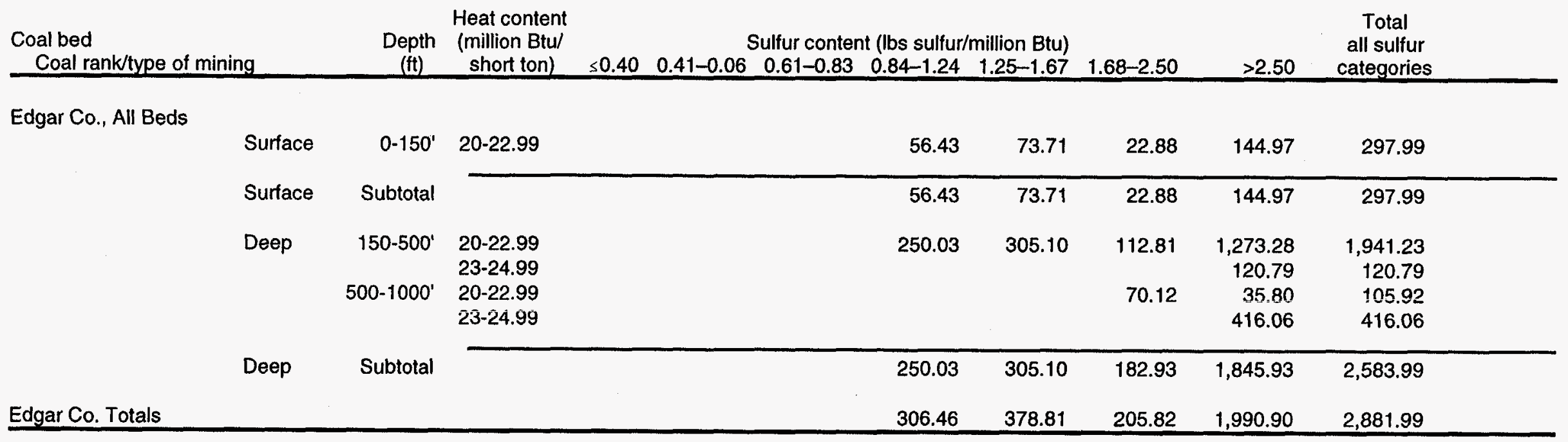

Edwards County

\begin{tabular}{|c|c|c|c|c|c|c|c|}
\hline \multicolumn{8}{|l|}{ Herrin } \\
\hline High Vol. B Bit. & Deep & $500-1000^{\prime}$ & $23-24.99$ & & & 208.52 & 208.52 \\
\hline \multicolumn{8}{|l|}{ Springfield } \\
\hline High Vol. B Bit. & Deep & $\begin{array}{r}500-1000^{\prime} \\
>1000^{\prime}\end{array}$ & $\begin{array}{l}23-24.99 \\
23-24.99\end{array}$ & 22.12 & $\begin{array}{r}27.14 \\
1.00\end{array}$ & $\begin{array}{r}117.52 \\
13.21\end{array}$ & $\begin{array}{r}166.79 \\
14.21\end{array}$ \\
\hline \multicolumn{8}{|c|}{ Edwards Co., All Beds } \\
\hline & Deep & $\begin{array}{r}500-1000^{\prime} \\
>1000^{\prime}\end{array}$ & $\begin{array}{l}23-24.99 \\
23-24.99\end{array}$ & 22.12 & $\begin{array}{r}27.14 \\
1.00\end{array}$ & $\begin{array}{r}326.04 \\
13.21\end{array}$ & $\begin{array}{r}375.31 \\
14.21\end{array}$ \\
\hline & Deep & Subtotal & & 22.12 & 28.14 & 339.25 & 389.52 \\
\hline \multicolumn{4}{|l|}{ Edwards Co. Totals } & 22.12 & 28.14 & 339.25 & 389.52 \\
\hline
\end{tabular}


Appendix 4 Remaining demonstrated reserve base in Illinois, January 1, 1996 (million short tons)

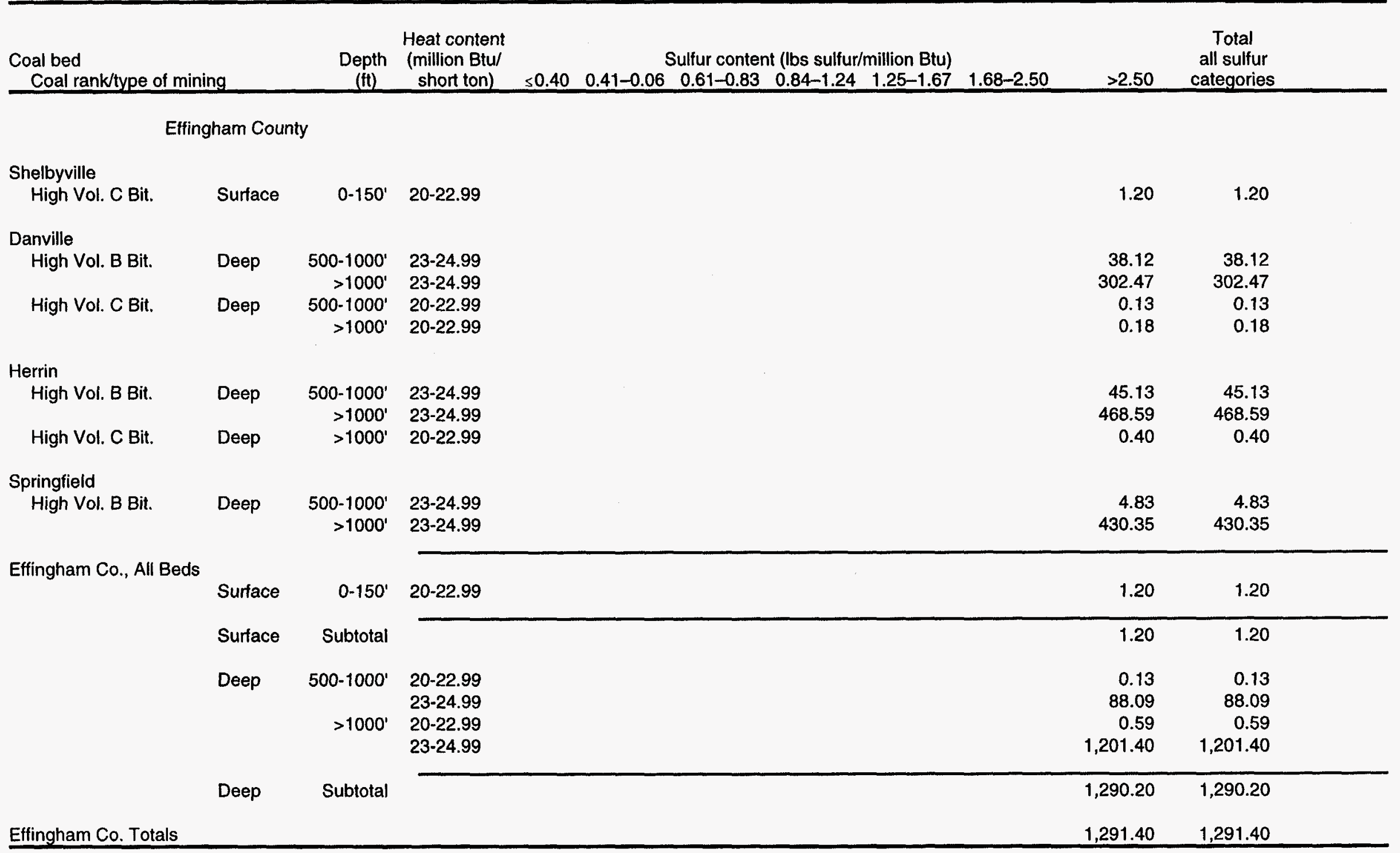


Appendix 4 Remaining demonstrated reserve base in Illinois, January 1, 1996 (million short tons)

8

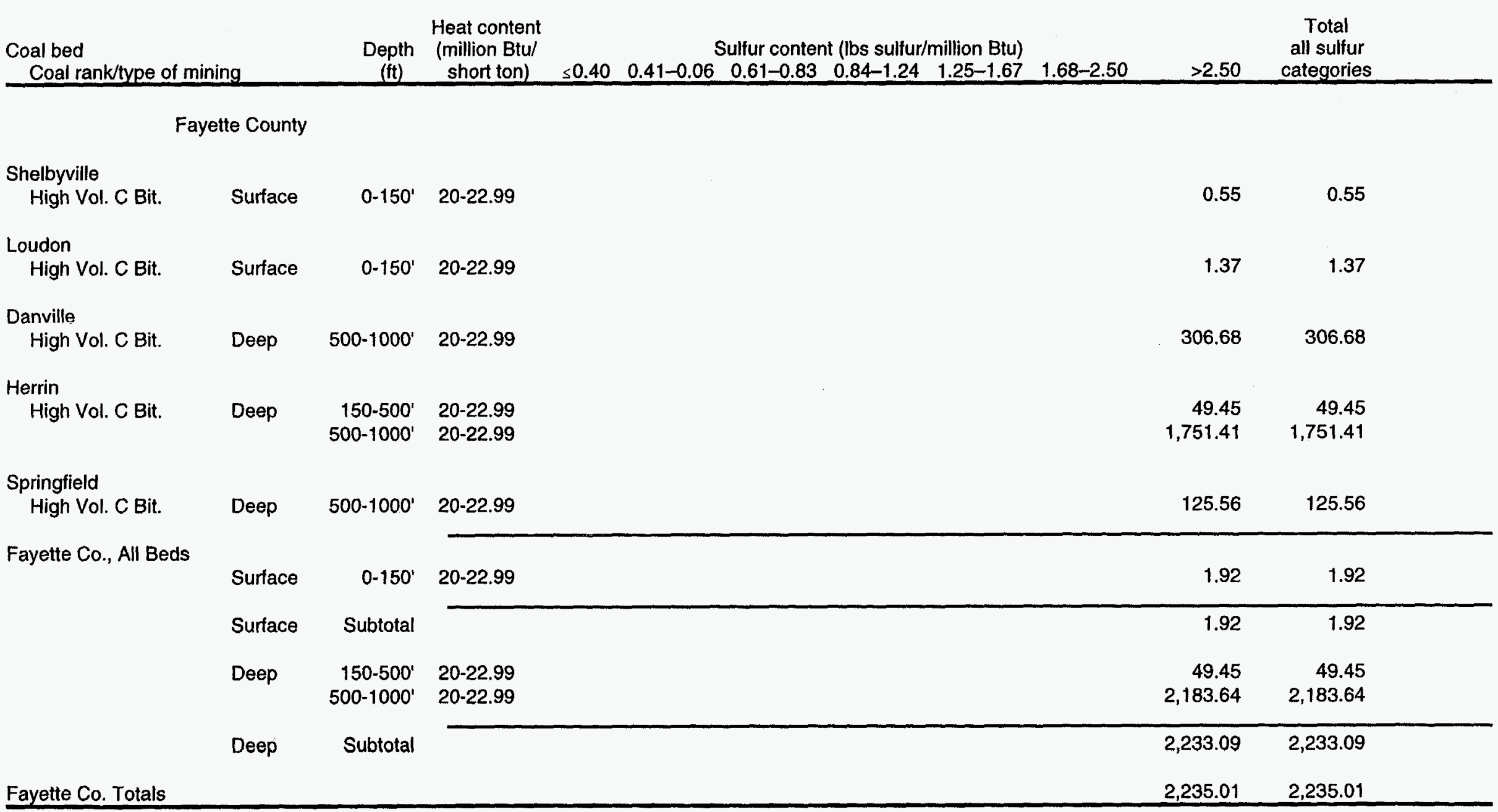

Franklin County

Belle Rive

High Vol. C Bit. $\quad$ Surface $\quad 0-150^{\prime} \quad 20-22.99$

1.75

1.75 
Appendix 4 Remaining demonstrated reserve base in Illinois, January 1, 1996 (million short tons)

\begin{tabular}{|c|c|c|c|c|c|c|c|c|c|c|c|}
\hline \multicolumn{2}{|c|}{$\begin{array}{l}\text { Coal bed } \\
\text { Coal rank/type of mining }\end{array}$} & $\begin{array}{c}\text { Depth } \\
\text { (ft) }\end{array}$ & $\begin{array}{c}\text { Heat content } \\
\text { (million Btu/ } \\
\text { short ton) } \\
\end{array}$ & \multicolumn{6}{|c|}{ Sulfur content (lbs sulfur/million Btu) } & \multicolumn{2}{|r|}{$\begin{array}{c}\text { Total } \\
\text { all sulfur } \\
\text { categories }\end{array}$} \\
\hline \multicolumn{12}{|l|}{ Herrin } \\
\hline High Vol. B Bit. & Deep & $150-500^{\prime}$ & $23-24.99$ & & & & 1.77 & 4.24 & 1.19 & 3.74 & 10.94 \\
\hline & & $500-1000^{\prime}$ & $23-24.99$ & & & 4.01 & 24.09 & 9.70 & 15.71 & $1,321.97$ & $1,375.49$ \\
\hline High Vol. C Bit. & Deep & $500-1000^{\prime}$ & $20-22.99$ & & & & 0.19 & 1.92 & 1.85 & 4.87 & 8.83 \\
\hline \multicolumn{12}{|l|}{ Springfield } \\
\hline \multirow[t]{3}{*}{ High Vol. B Bit. } & Deep & $150-500^{\prime}$ & $23-24.99$ & & & & & & & 241.42 & 241.42 \\
\hline & & $500-1000^{\prime}$ & 23-24.99 & & & & 0.03 & 17.30 & 254.33 & $1,237.44$ & $1,509.11$ \\
\hline & & $>1000^{\prime}$ & 23-24.99 & & & & & & & 25.54 & 25.54 \\
\hline \multirow[t]{2}{*}{ High Vol. C Bit. } & Deep & $150-500^{\prime}$ & $20-22.99$ & & & & & & & 71.02 & 71.02 \\
\hline & & $500-1000^{\prime}$ & $20-22.99$ & & & & & & & 162.95 & 162.95 \\
\hline \multicolumn{12}{|l|}{ DeKoven } \\
\hline High Vol. B Bit. & Deep & $500-1000^{\prime}$ & $23-24.99$ & & & & & & & 106.39 & 106.39 \\
\hline \multicolumn{12}{|l|}{ Davis } \\
\hline High Vol. B Bit. & Deep & $500-1000^{\prime}$ & $23-24.99$ & & & & & & & 179.52 & 179.52 \\
\hline High Vol. C Bit. & Deep & $500-1000^{\prime}$ & $20-22.99$ & & & & & & & 5.71 & 5.71 \\
\hline \multicolumn{12}{|l|}{ Mt. Rorah } \\
\hline \multirow[t]{2}{*}{ High Vol. B Bit. } & Deep & $500-1000^{\prime}$ & $23-24.99$ & & & & & & & 63.24 & 63.24 \\
\hline & & $>1000^{\prime}$ & $23-24.99$ & & & & & & & 11.22 & 11.22 \\
\hline \multirow{9}{*}{$\begin{array}{l}\text { High Vol. C Bit. } \\
\text { Franklin Co., All Bed }\end{array}$} & Deep & $500-1000^{\prime}$ & $20-22.99$ & & & & & & & 0.75 & 0.75 \\
\hline & & & & & & & & & & & \\
\hline & Surface & $0-150^{\prime}$ & $20-22.99$ & & & & & & & 1.75 & 1.75 \\
\hline & Surface & Subtotal & & & & & & & & 1.75 & 1.75 \\
\hline & Deep & $150-500^{\prime}$ & $20-22.99$ & & & & & & & 71.02 & 71.02 \\
\hline & & & 23-24.99 & & & & 1.77 & 4.24 & 1.19 & 245.16 & 252.36 \\
\hline & & $500-1000^{\prime}$ & $20-22.99$ & & & & 0.19 & 1.92 & 1.85 & 174.27 & 178.24 \\
\hline & & & $23-24.99$ & & & 4.01 & 24.12 & 27.01 & 270.05 & $2,908.56$ & $3,233.75$ \\
\hline & & $>1000^{\circ}$ & $23-24.99$ & & & & & & & 36.76 & 36.76 \\
\hline
\end{tabular}


Appendix 4 Remaining demonstrated reserve base in Illinois, January 1, 1996 (million short tons)

\begin{tabular}{|c|c|c|c|c|c|c|c|c|c|c|c|}
\hline \multicolumn{2}{|c|}{$\begin{array}{l}\text { Coal bed } \\
\text { Coal rank/type of mining }\end{array}$} & $\begin{array}{c}\text { Depth } \\
\text { (ft) }\end{array}$ & \multirow[t]{2}{*}{$\begin{array}{l}\text { Heat content } \\
\text { (million Btu/ } \\
\text { short ton) }\end{array}$} & \multicolumn{6}{|c|}{$\begin{array}{l}\text { Sulfur content (lbs sulfur/million Btu) } \\
\end{array}$} & \multicolumn{2}{|r|}{$\begin{array}{c}\text { Total } \\
\text { all sulfur } \\
\text { categories }\end{array}$} \\
\hline & Deep & Subtotal & & & & 4.01 & 26.09 & 33.17 & 273.09 & $3,435.77$ & $3,772.12$ \\
\hline \multicolumn{4}{|l|}{ Franklin Co. Totals } & & & 4.01 & 26.09 & 33.17 & 273.09 & $3,437.53$ & $3,773.88$ \\
\hline \multicolumn{12}{|c|}{ Fulton County } \\
\hline High Vol. C Bit. & Surface & $0-150^{\prime}$ & $20-22.99$ & & & & & & & 41.98 & 41.98 \\
\hline \multicolumn{12}{|l|}{ Herrin } \\
\hline \multirow[t]{2}{*}{ High Vol. C Bit. } & Surface & $0-150^{\prime}$ & $20-22.99$ & & & & & & & 242.67 & 242.67 \\
\hline & Deep & $150-500^{\prime}$ & $20-22.99$ & & & & & & & 3.63 & 3.63 \\
\hline \multicolumn{12}{|l|}{ Springfield } \\
\hline \multirow[t]{2}{*}{ High Vol. C Bit. } & Surface & $0-150^{\circ}$ & $20-22.99$ & & & & & & & 576.00 & 576.00 \\
\hline & Deep & $150-500^{\prime}$ & $20-22.99$ & & & & & & & 80.22 & 80.22 \\
\hline \multicolumn{12}{|l|}{ Colchester } \\
\hline \multirow[t]{2}{*}{ High Vol. C Bit. } & Surface & $0-150^{\prime}$ & $20-22.99$ & & & & & & & 958.29 & 958.29 \\
\hline & Deep & $150-500^{\prime}$ & $20-22.99$ & & & & & & & 82.31 & 82.31 \\
\hline \multicolumn{12}{|l|}{ Rock Island } \\
\hline \multirow[t]{2}{*}{ High Vol. C Bit. } & Surface & $0-150^{\prime}$ & $20-22.99$ & & & & & & & 8.03 & 8.03 \\
\hline & Deep & $150-500^{\prime}$ & $20-22.99$ & & & & & & & 0.15 & 0.15 \\
\hline \multirow[t]{5}{*}{ Fulton Co., All Beds } & & & & & & & & & & & \\
\hline & Surface & $0-150^{\prime}$ & $20-22.99$ & & & & & & & $1,826.96$ & $1,826.96$ \\
\hline & Surface & Subtotal & & & & & & & & $1,826.96$ & $1,826.96$ \\
\hline & Deep & $150-500^{\prime}$ & $20-22.99$ & & & & & & & 166.30 & 166.30 \\
\hline & Deep & Subtotal & & & & & & & & 166.30 & 166.30 \\
\hline Fulton Co. Totals & & & & & & & & & & $1,993.26$ & $1,993.26$ \\
\hline
\end{tabular}


Appendix 4 Remaining demonstrated reserve base in Illinois, January 1, 1996 (million short tons)

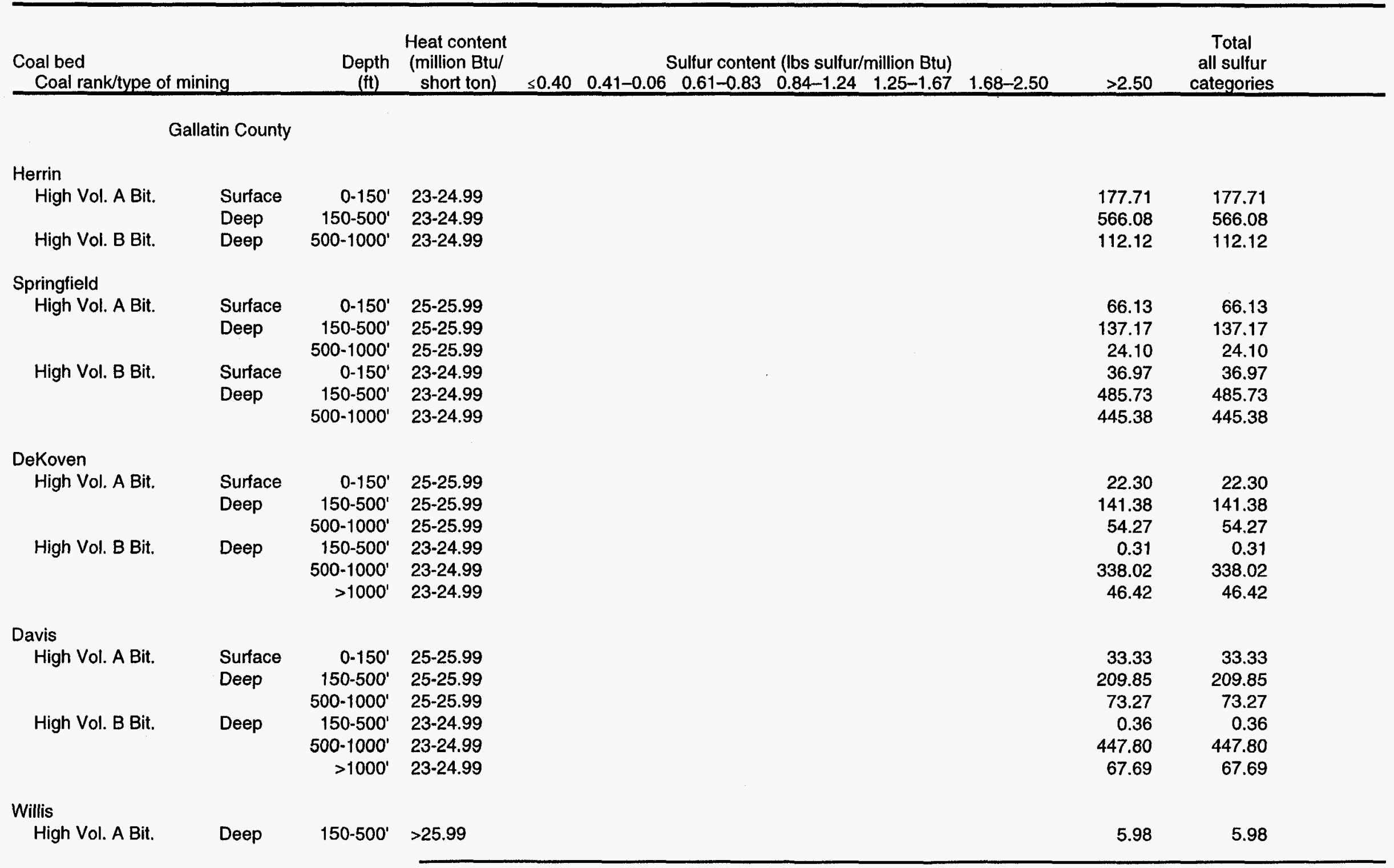


Appendix 4 Remaining demonstrated reserve base in lllinois, January 1, 1996 (million short tons)

$\$$

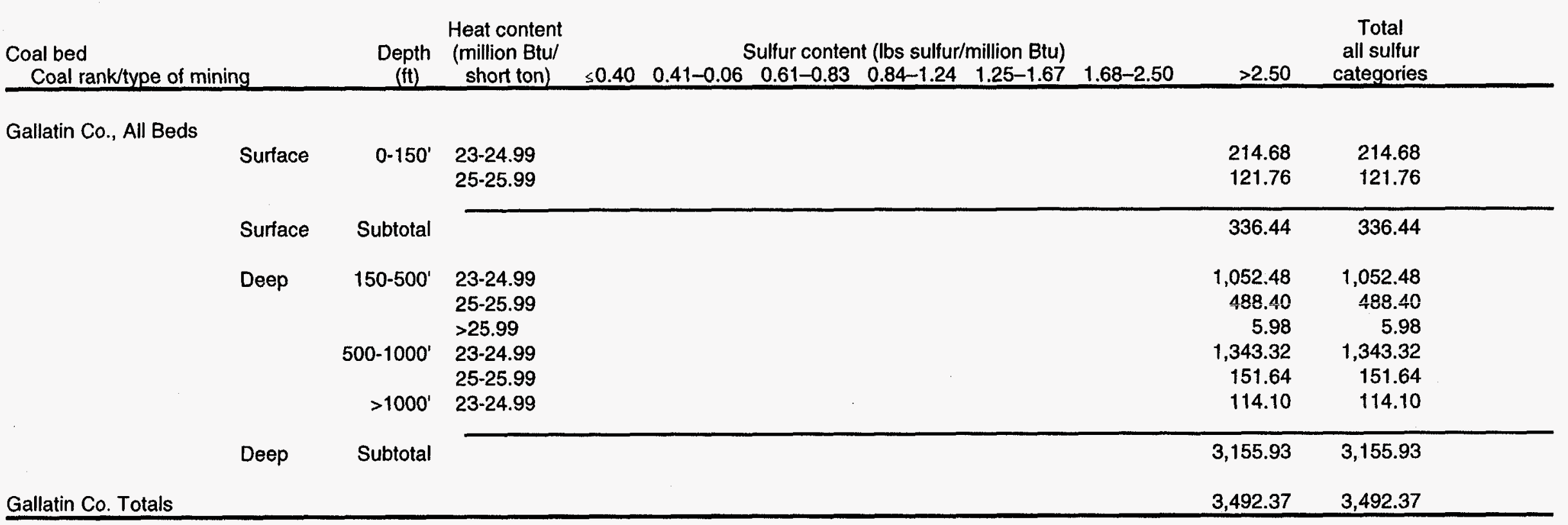

Greene County

\begin{tabular}{|c|c|c|c|c|c|}
\hline \multicolumn{6}{|l|}{ Herrin } \\
\hline High Vol. C Bit. & Surface & $0.150^{\prime}$ & $20-22.99$ & 75.00 & 75.00 \\
\hline \multicolumn{6}{|l|}{ Colchester } \\
\hline High Vol. C Bit. & Surface & $0-150^{\prime}$ & $20-22.99$ & 377.99 & 377.99 \\
\hline & Deep & $150-500^{\prime}$ & $20-22.99$ & 17.93 & 17.93 \\
\hline \multicolumn{6}{|l|}{ Greene Co., All Beds } \\
\hline & Surface & $0-150^{\prime}$ & $20-22.99$ & 452.99 & 452.99 \\
\hline & Surface & Subtotal & & 452.99 & 452.99 \\
\hline & Deep & $150-500^{\prime}$ & $20-22.99$ & 17.93 & 17.93 \\
\hline & Deep & Subtotal & & 17.93 & 17.93 \\
\hline
\end{tabular}


Appendix 4 Remaining demonstrated reserve base in Illinois, January 1, 1996 (million short tons)

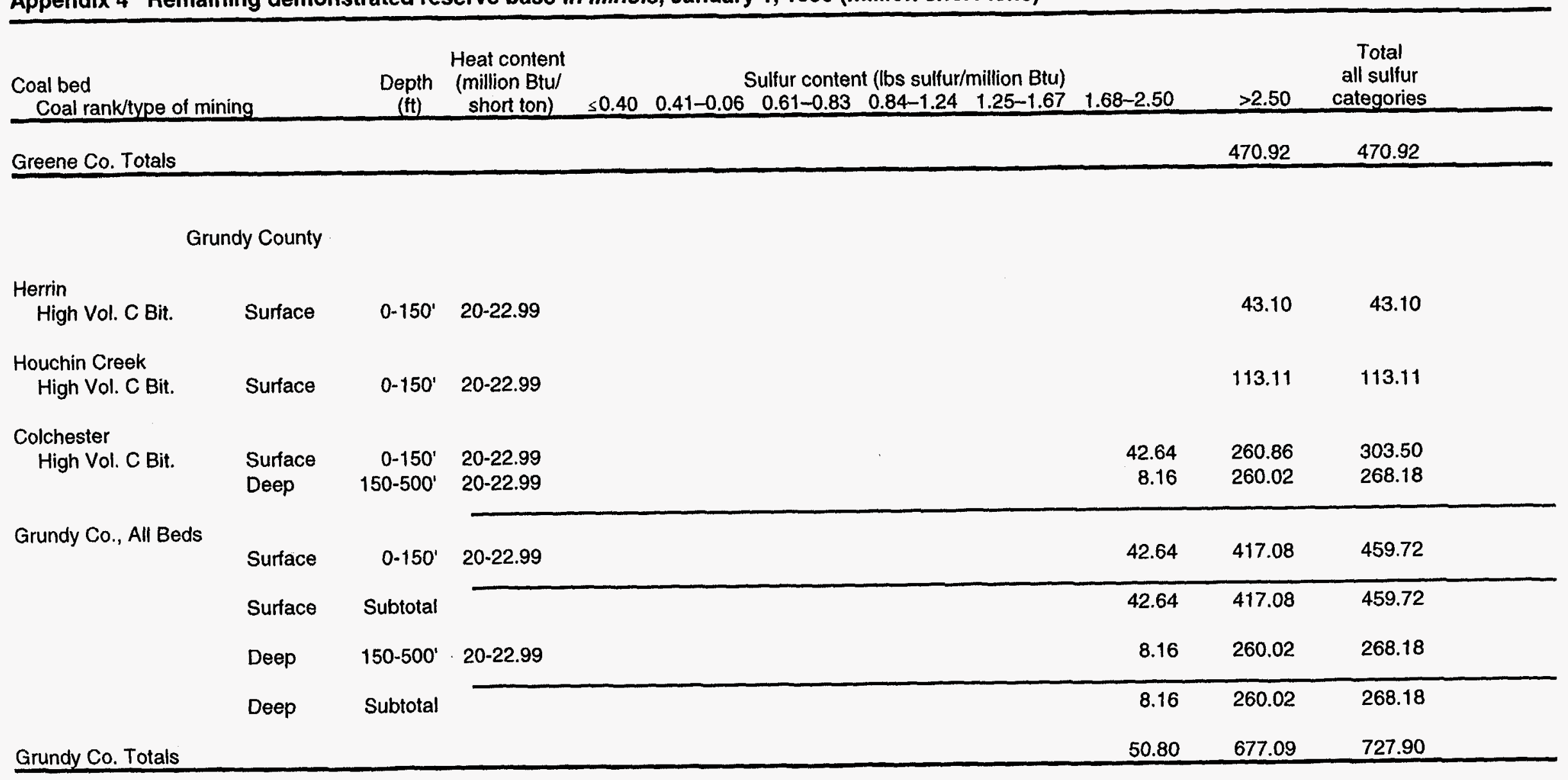

Hamilton County

Herrin

\begin{tabular}{|c|c|c|}
\hline High Vol. B Bit. & Deep & $\begin{array}{r}150-500^{\prime} \\
500-1000^{\prime} \\
>1000^{\prime}\end{array}$ \\
\hline
\end{tabular}

$\begin{array}{rr}0.05 & 0.05 \\ 1,827.43 & 1,827.43 \\ 217.60 & 217.60\end{array}$


Appendix 4 Remaining demonstrated reserve base in Illinois, January 1, 1996 (million short tons)

\begin{tabular}{|c|c|c|c|c|c|c|c|c|c|c|}
\hline $\begin{array}{l}\text { Coal bed } \\
\text { Coal rank/type of mining }\end{array}$ & $\begin{array}{l}\text { Depth } \\
\text { (ft) }\end{array}$ & $\begin{array}{c}\text { Heat content } \\
\text { (million Btu/ } \\
\text { short ton) }\end{array}$ & $\leq 0.40$ & $0.41-0.06$ & $\begin{array}{c}\text { Sulfur conter } \\
0.61-0.83 \\
\end{array}$ & $\begin{array}{r}\text { t (Ibs sulfur } \\
0.84-1.24 \\
\end{array}$ & $\begin{array}{r}\text { /million Btu) } \\
1.25-1.67 \\
\end{array}$ & $1.68-2.50$ & $>2.50$ & $\begin{array}{c}\text { Total } \\
\text { all sulfur } \\
\text { categories } \\
\end{array}$ \\
\hline $\begin{array}{l}\text { Springfield } \\
\text { High Vol. B Bit. }\end{array}$ & $\begin{array}{r}500-1000^{\prime} \\
>1000^{\prime}\end{array}$ & $\begin{array}{l}23-24.99 \\
23-24.99\end{array}$ & & & 30.71 & $\begin{array}{r}434.21 \\
3.67\end{array}$ & $\begin{array}{r}149.43 \\
22.36\end{array}$ & $\begin{array}{r}92.46 \\
138.67\end{array}$ & $\begin{array}{l}484.14 \\
426.60\end{array}$ & $\begin{array}{r}1,190.95 \\
591.30\end{array}$ \\
\hline Hamilton Co., All Beds & $\begin{array}{r}150-500^{\prime} \\
500-1000^{\prime} \\
>1000^{\prime}\end{array}$ & $\begin{array}{l}23-24.99 \\
23-24.99 \\
23-24.99\end{array}$ & & & 30.71 & $\begin{array}{r}434.21 \\
3.67\end{array}$ & $\begin{array}{r}149.43 \\
22.36\end{array}$ & $\begin{array}{r}92.46 \\
138.67\end{array}$ & $\begin{array}{r}0.05 \\
2,311.57 \\
644.20\end{array}$ & $\begin{array}{r}0.05 \\
3,018.39 \\
808.90\end{array}$ \\
\hline Hamilton Co. Totals & Subtotal & & & & $\begin{array}{r}30.71 \\
30.71 \\
\end{array}$ & $\begin{array}{r}437.88 \\
437.88 \\
\end{array}$ & $\begin{array}{l}171.79 \\
171.79\end{array}$ & $\begin{array}{l}231.13 \\
231.13 \\
\end{array}$ & $\begin{array}{r}2,955.82 \\
2,955.82 \\
\end{array}$ & $\begin{array}{l}3,827.34 \\
3,827.34 \\
\end{array}$ \\
\hline
\end{tabular}

Hancock County

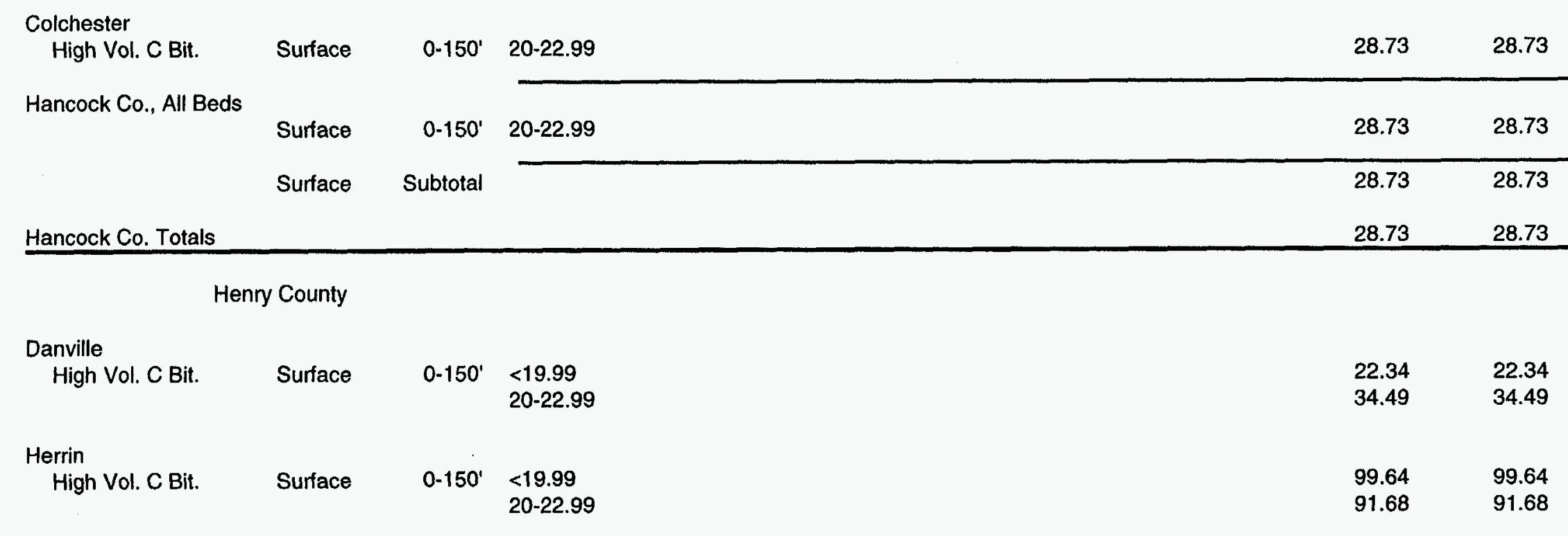


Appendix 4 Remaining demonstrated reserve base in Illinois, January 1, 1996 (million short tons)

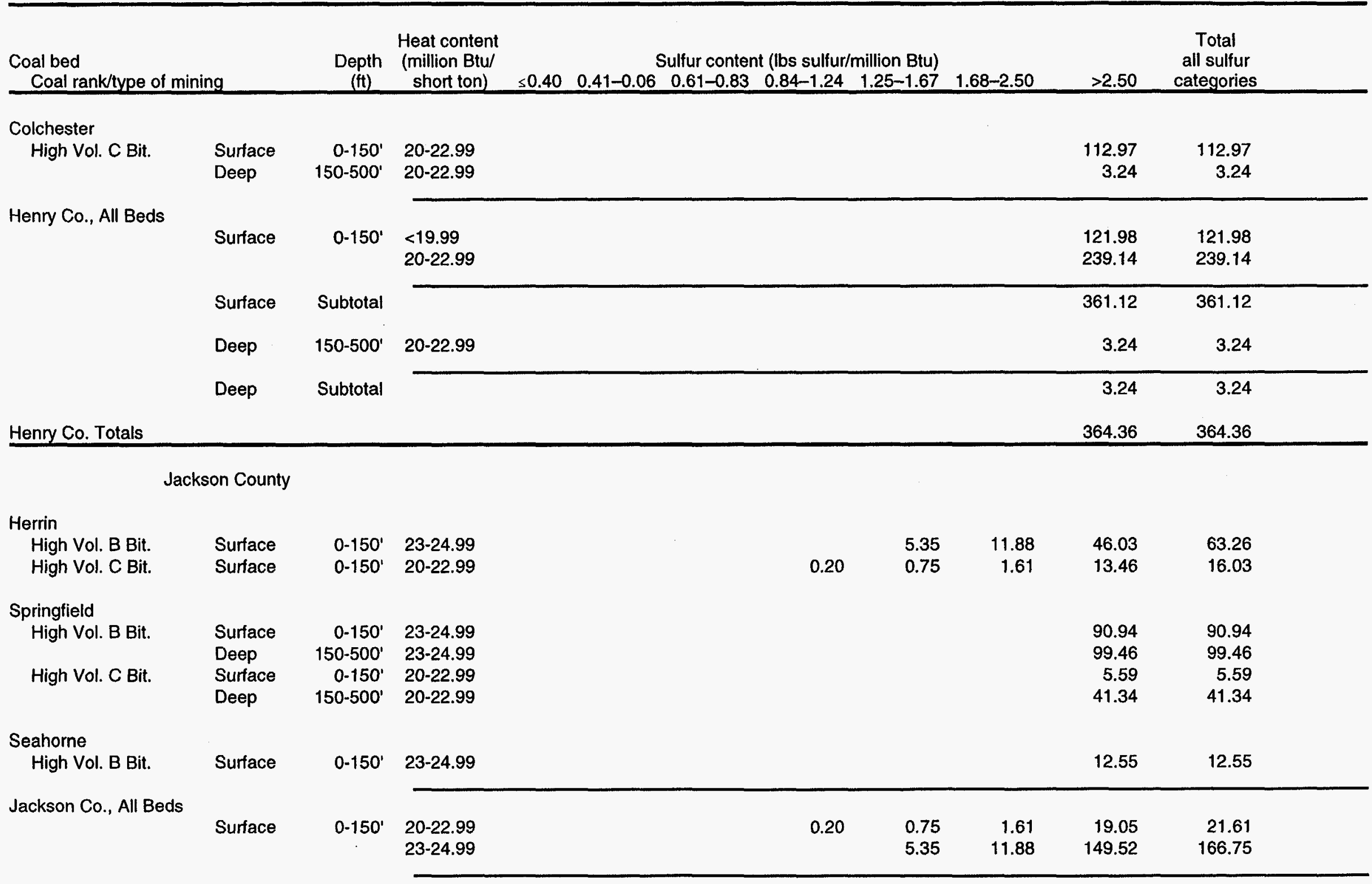


Appendix 4 Remaining demonstrated reserve base in Illinois, January 1, 1996 (million short tons)

$\infty$

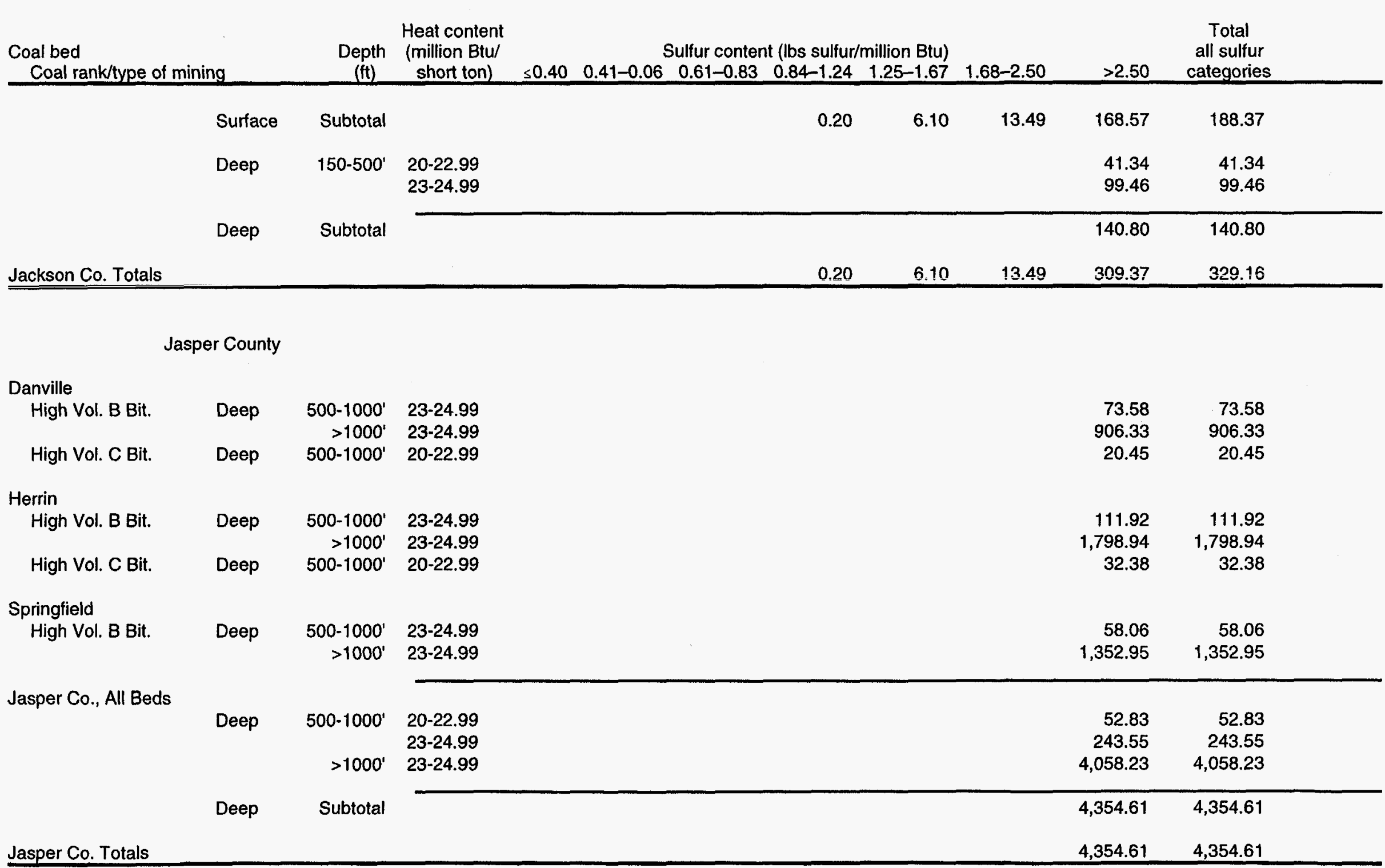


Appendix 4 Remaining demonstrated reserve base in Illinois, January 1, 1996 (million short tons)

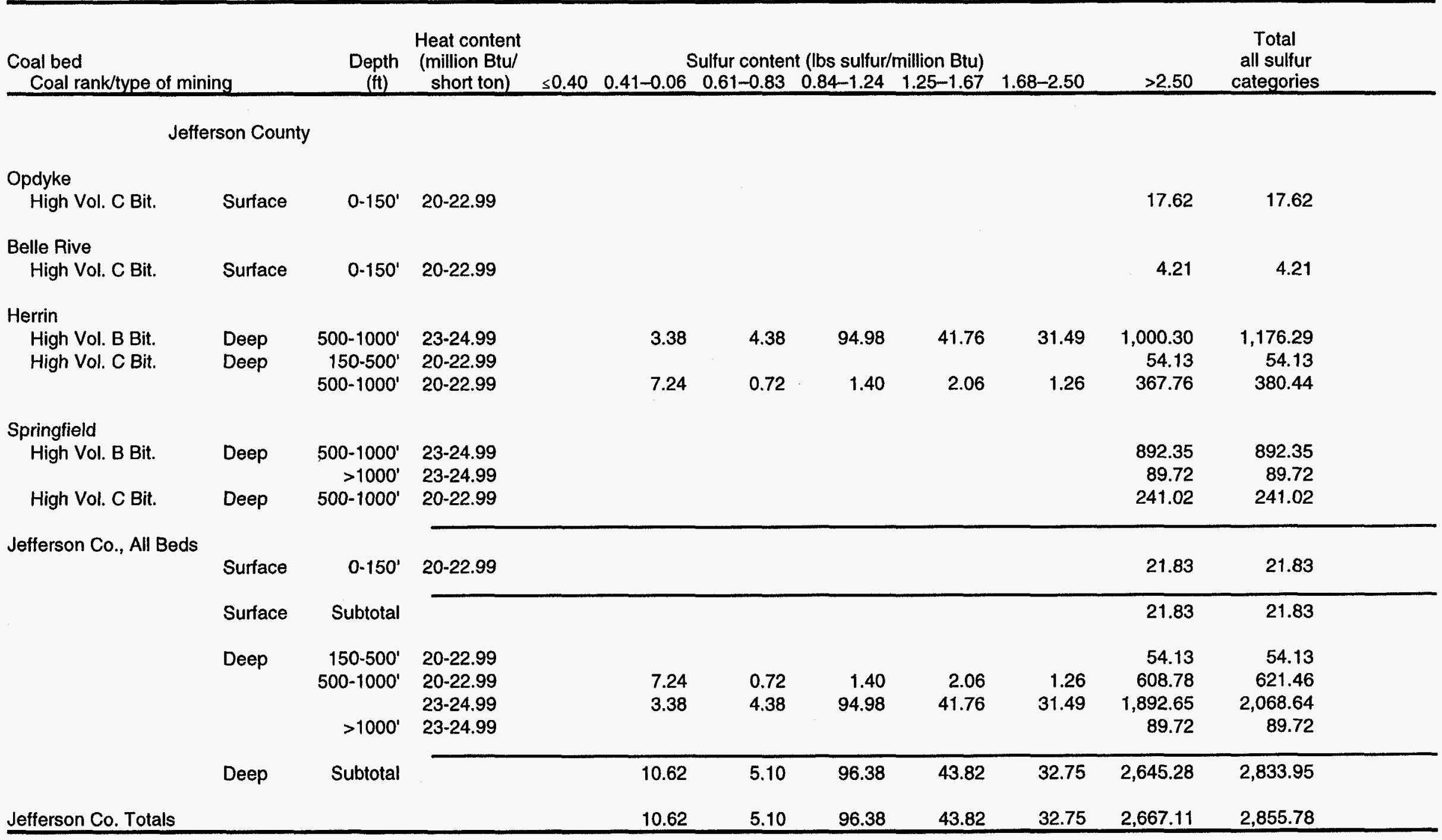


Appendix 4 Remaining demonstrated reserve base in Illinois, January 1, 1996 (million short tons)

ปั

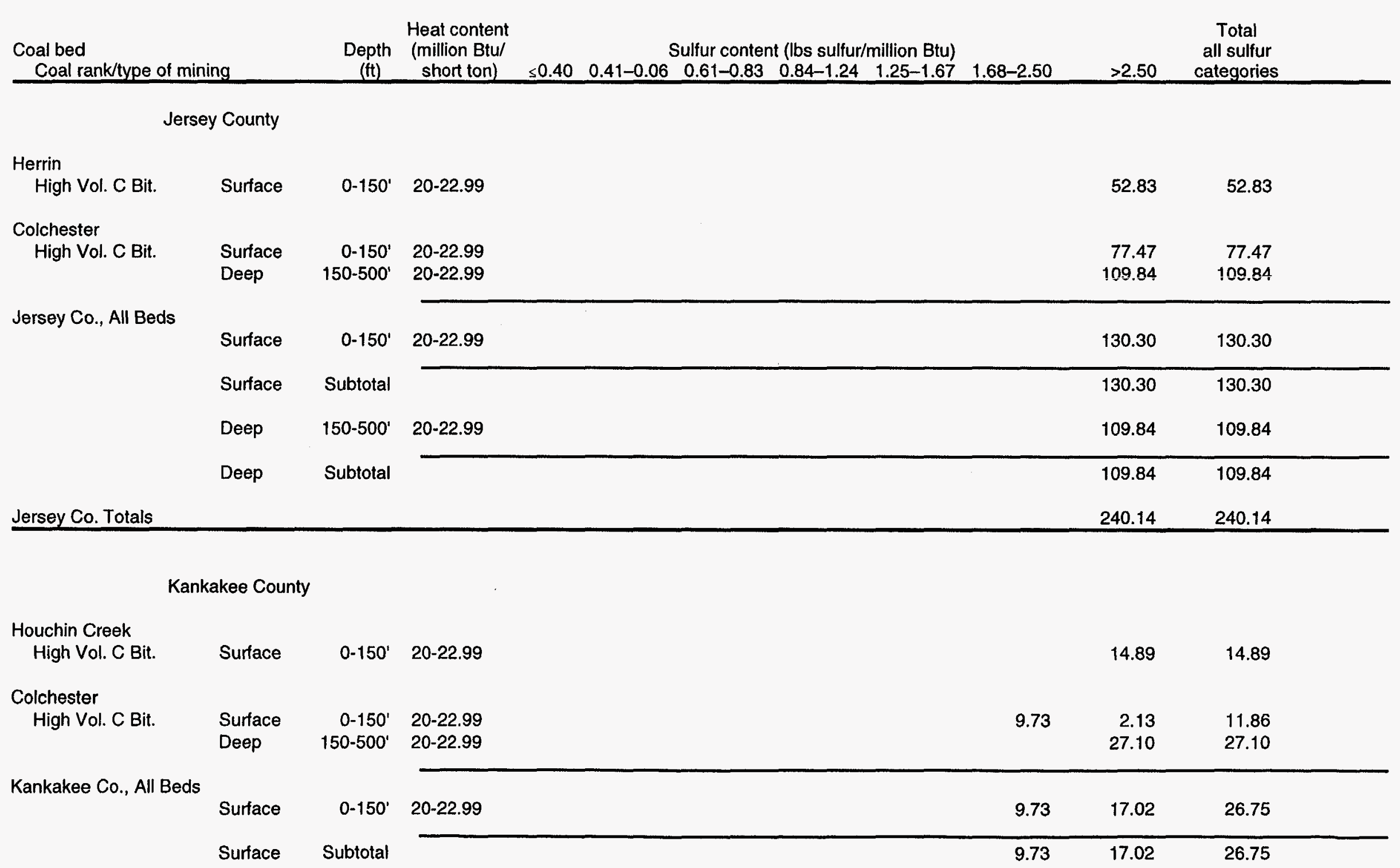


Appendix 4 Remaining demonstrated reserve base in Illinois, January 1, 1996 (million short tons)

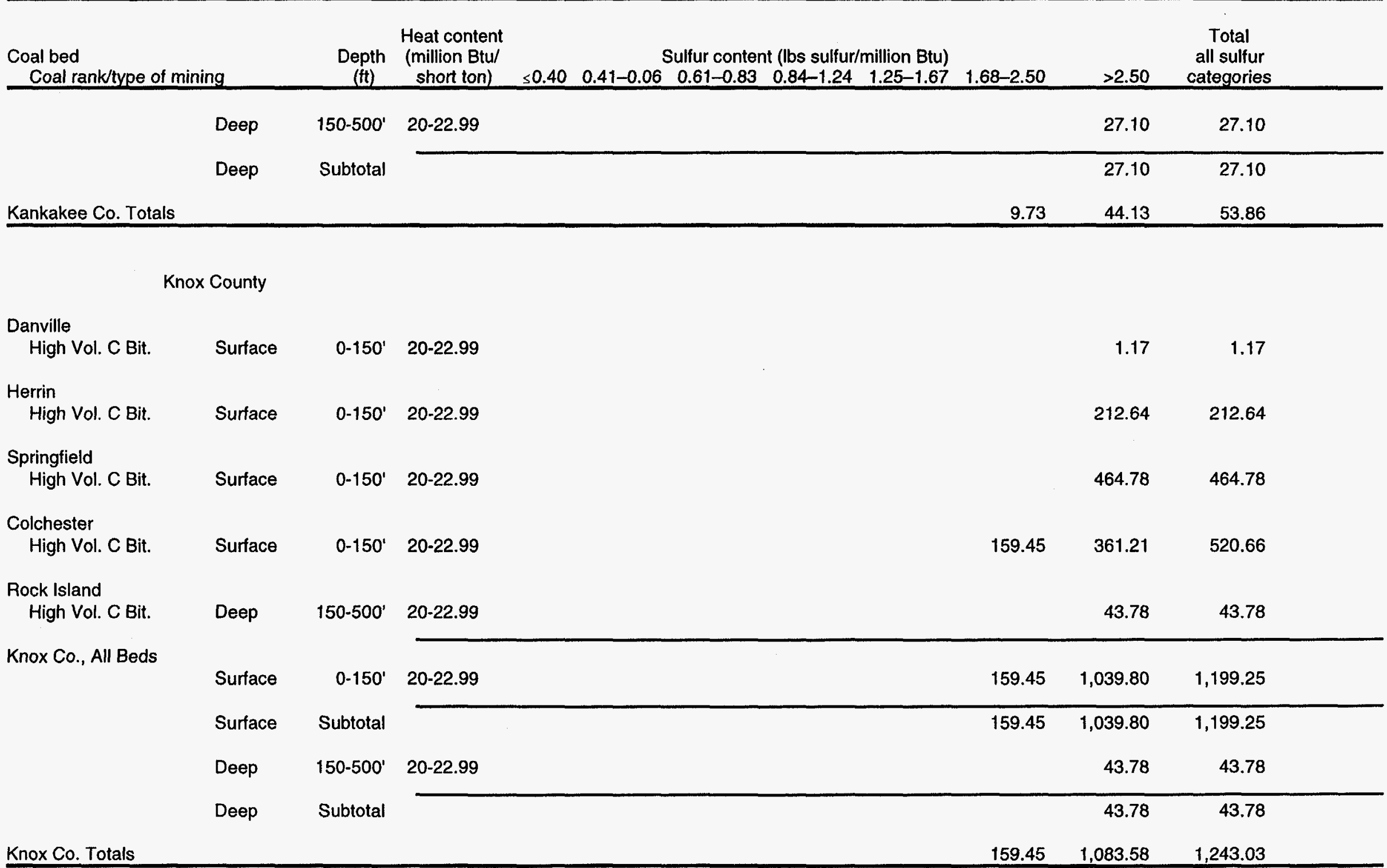


Appendix 4 Remaining demonstrated reserve base in Illinois, January 1, 1996 (million short tons)

N

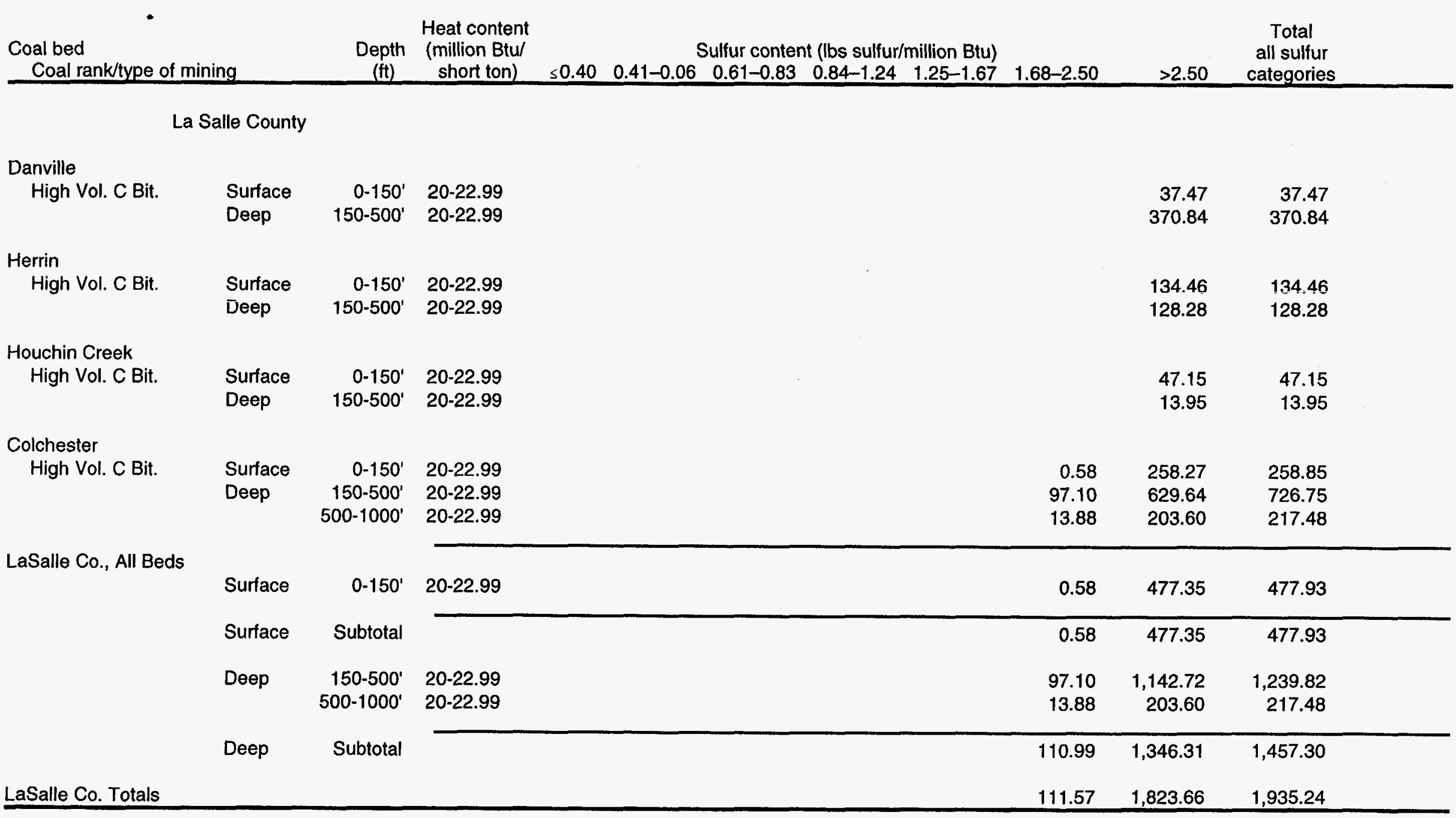


Appendix 4 Remaining demonstrated reserve base in Illinois, January 1, 1996 (million short tons)

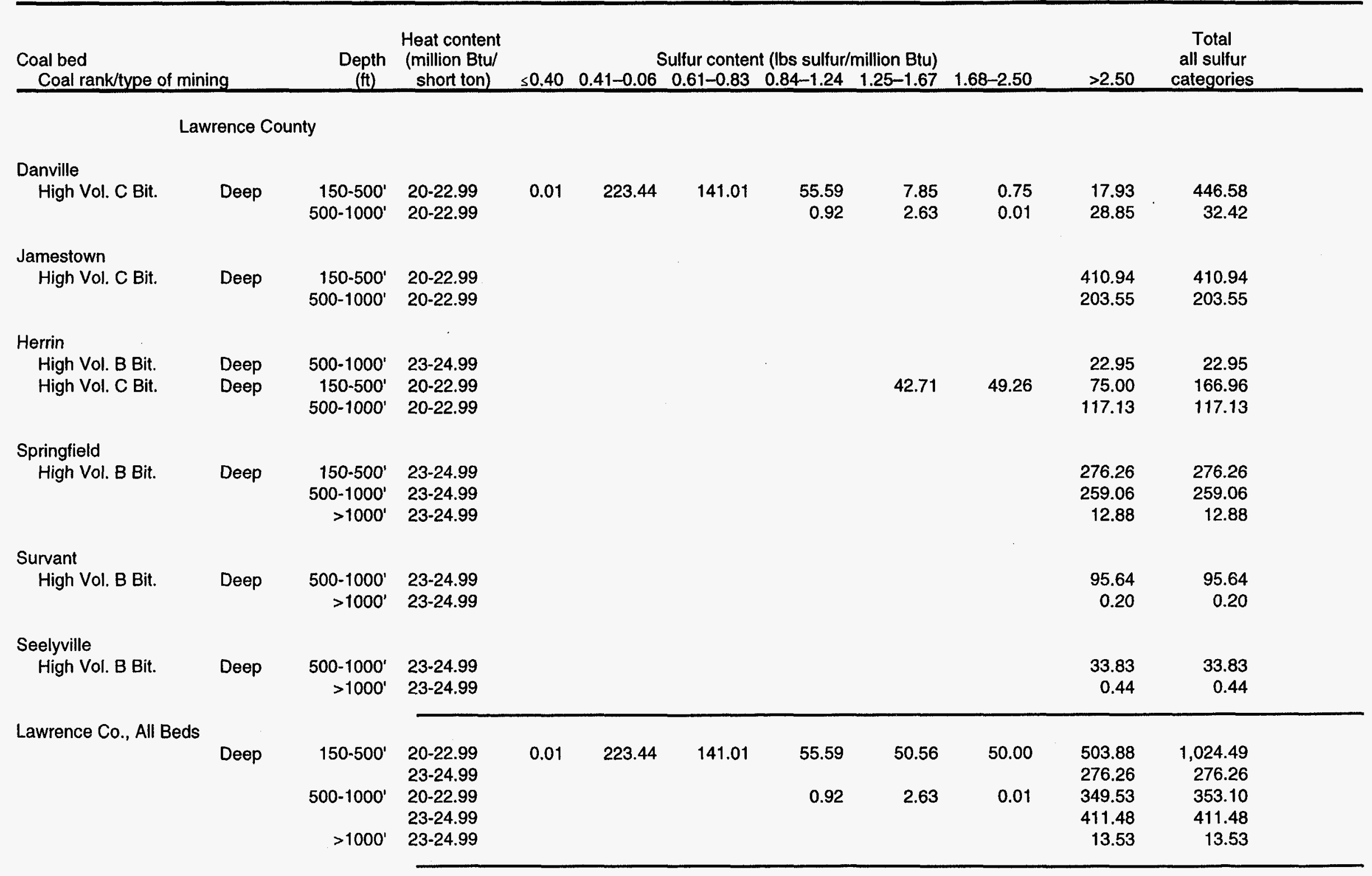


Appendix 4 Remaining demonstrated reserve base in Illinois, January 1, 1996 (million short tons)

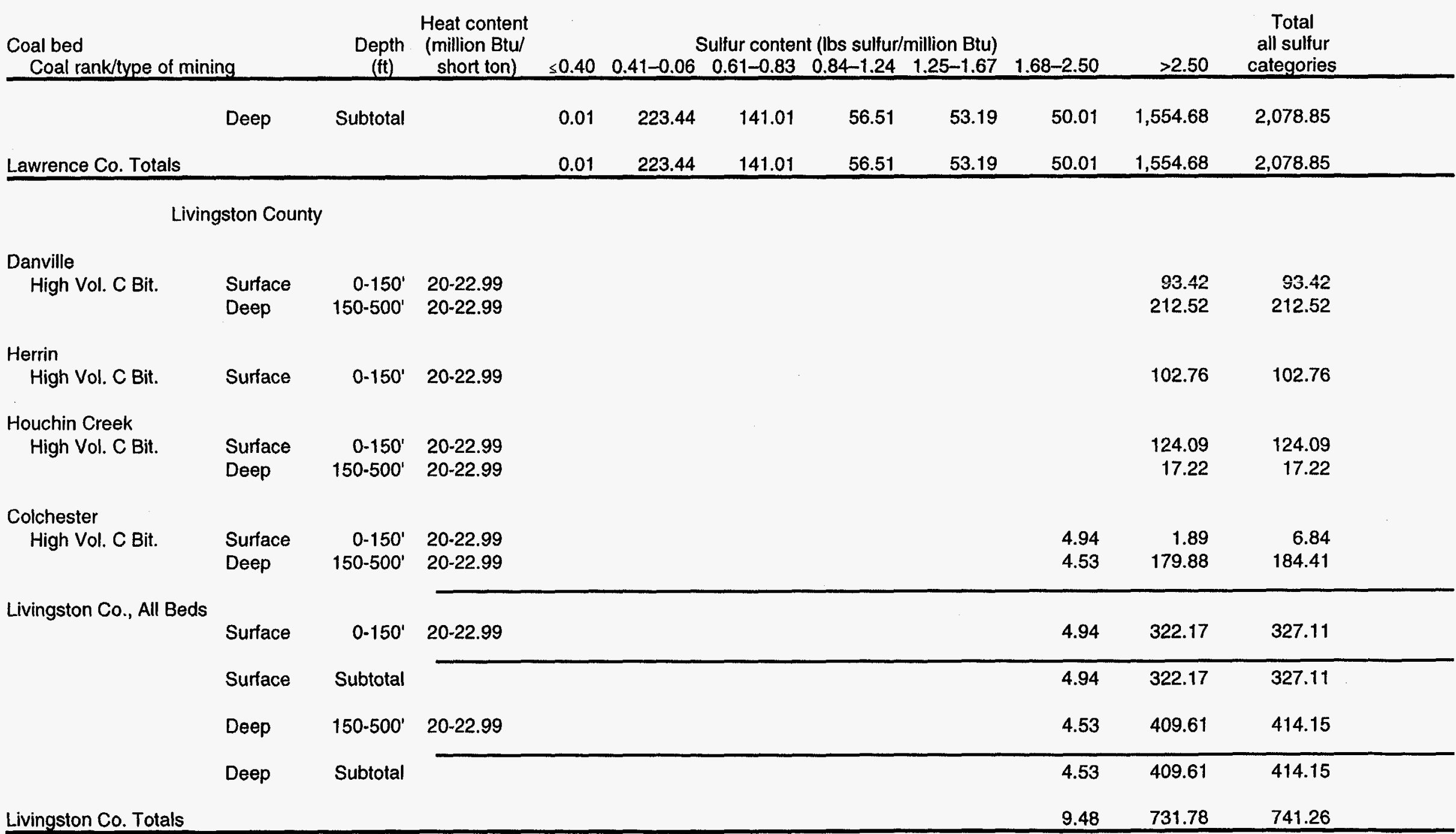


Appendix 4 Remaining demonstrated reserve base in Illinois, January 1, 1996 (million short tons)

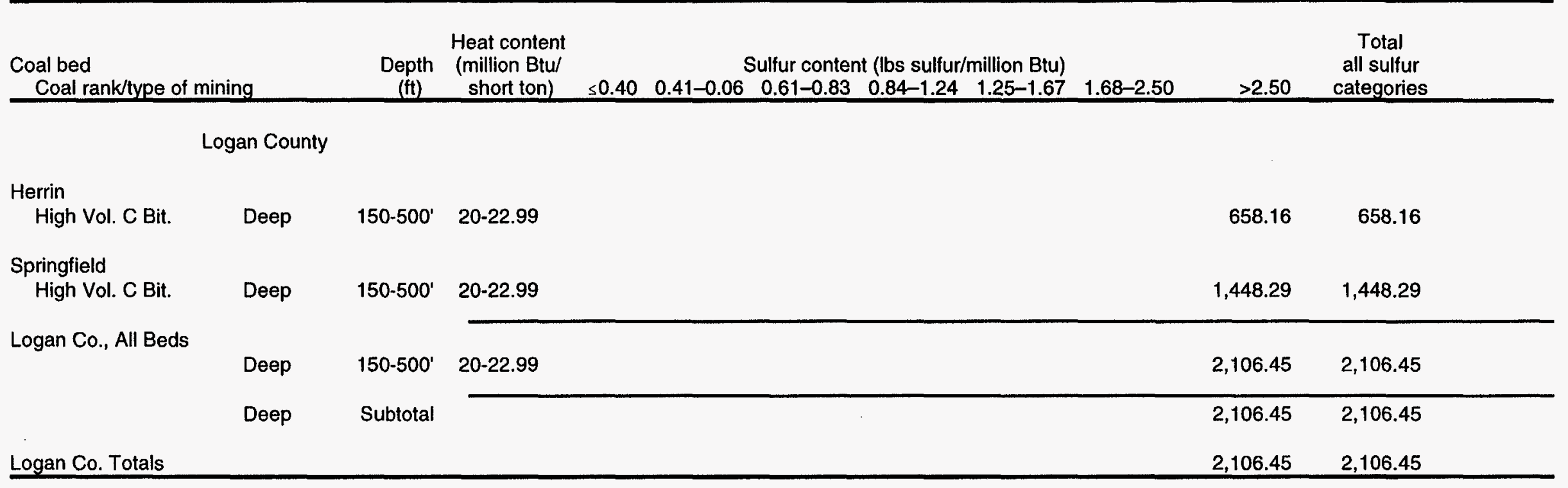

McDonough County

Colchester

High Vol. C Bit. Surface

McDonough Co., All Beds

\begin{tabular}{lrrrrr} 
Surface & $0-150^{\prime}$ & $20-22.99$ & 348.35 & 348.35 \\
\cline { 3 - 6 } Surface & Subtotal & 348.35 & 348.35 \\
& & & 348.35 & 348.35 \\
\hline
\end{tabular}

McDonough Co. Totals

McLean County

Danville

$\begin{array}{rr}188.13 & 188.13 \\ 35.51 & 35.51\end{array}$


Appendix 4 Remaining demonstrated reserve base in Illinois, January 1, 1996 (million short tons)

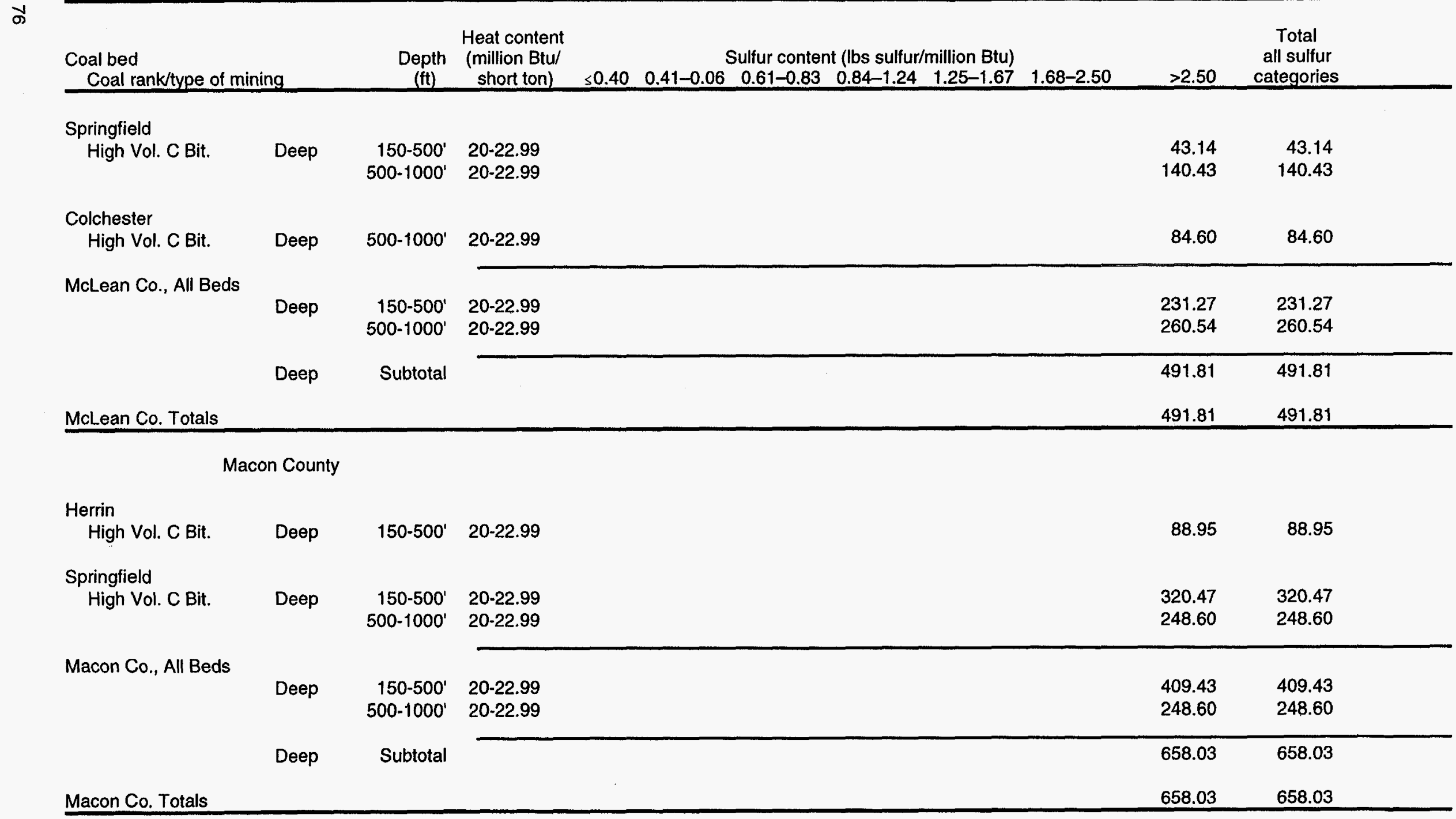


Appendix 4 Remaining demonstrated reserve base in Illinois, January 1, 1996 (million short tons)

\begin{tabular}{|c|c|c|c|c|c|c|c|c|c|c|c|}
\hline \multicolumn{2}{|c|}{$\begin{array}{l}\text { Coal bed } \\
\text { Coal rank/type of mining }\end{array}$} & \multirow[t]{2}{*}{$\begin{array}{c}\text { Depth } \\
\text { (ft) }\end{array}$} & \multirow[t]{2}{*}{$\begin{array}{c}\text { Heat content } \\
\text { (million Btu/ } \\
\text { short ton) }\end{array}$} & \multicolumn{6}{|c|}{$\begin{array}{c}\text { Sulfur content (lbs sulfur/million Btu) } \\
0.40 \quad 0.41-0.06 \quad 0.61-0.83 \quad 0.84-124 \quad 125-167 \\
168-250\end{array}$} & \multicolumn{2}{|r|}{$\begin{array}{c}\text { Total } \\
\text { all sulfur } \\
\text { categories }\end{array}$} \\
\hline \multicolumn{10}{|c|}{ Macoupin County } & & \\
\hline \multicolumn{12}{|l|}{ Danville } \\
\hline High Vol. C Bit. & Deep & $150-500^{\prime}$ & $20-22.99$ & & & & & & & 14.06 & 14.06 \\
\hline \multicolumn{12}{|l|}{ Herrin } \\
\hline High Vol. C Bit. & $\begin{array}{l}\text { Surface } \\
\text { Deep }\end{array}$ & $\begin{array}{r}0-150^{\prime} \\
150-500^{\prime}\end{array}$ & $\begin{array}{l}20-22.99 \\
20-22.99\end{array}$ & & & 116.67 & 134.44 & 76.86 & 109.94 & $\begin{array}{r}265.51 \\
2,826.02\end{array}$ & $\begin{array}{r}265.51 \\
3,263.93\end{array}$ \\
\hline \multicolumn{12}{|l|}{ Colchester } \\
\hline High Vol. C Bit. & $\begin{array}{l}\text { Surface } \\
\text { Deep }\end{array}$ & $\begin{array}{r}0-150^{\prime} \\
150-500^{\prime} \\
500-1000^{\prime}\end{array}$ & $\begin{array}{l}20-22.99 \\
20-22.99 \\
20-22.99\end{array}$ & & & & & & & $\begin{array}{r}13.08 \\
194.93 \\
77.91\end{array}$ & $\begin{array}{r}13.08 \\
194.93 \\
77.91\end{array}$ \\
\hline \multicolumn{12}{|l|}{ Wiley } \\
\hline High Vol. C Bit. & Deep & $\begin{array}{r}150-500^{\prime} \\
500-1000^{\prime}\end{array}$ & $\begin{array}{l}20-22.99 \\
20-22.99\end{array}$ & & & & & & & $\begin{array}{r}0.13 \\
43.90\end{array}$ & $\begin{array}{r}0.13 \\
43.90\end{array}$ \\
\hline \multicolumn{12}{|l|}{ Litchfield } \\
\hline High Vol. C Bit. & Deep & $500-1000^{\prime}$ & $20-22.99$ & & & & & & & 70.72 & 70.72 \\
\hline \multirow[t]{5}{*}{ Macoupin Co., All Beds } & & & & & & & & & & & \\
\hline & Surface & $0-150^{\prime}$ & 20-22.99 & & & & & & & 278.59 & 278.59 \\
\hline & Surface & Subtotal & & & & & & & & 278.59 & 278.59 \\
\hline & Deep & $\begin{array}{r}150-500^{\prime} \\
500-1000^{\prime}\end{array}$ & $\begin{array}{l}20-22.99 \\
20-22.99\end{array}$ & & & 116.67 & 134.44 & 76.86 & 109.94 & $\begin{array}{r}3,035.15 \\
192.53\end{array}$ & $\begin{array}{r}3,473.06 \\
192.53\end{array}$ \\
\hline & Deep & Subtotal & & & & 116.67 & 134.44 & 76.86 & 109.94 & $3,227.67$ & $3,665.58$ \\
\hline Macoupin Co. Totals & & . & & & & 116.67 & 134.44 & 76.86 & 109.94 & $3,506.26$ & $3,944.17$ \\
\hline
\end{tabular}


Appendix 4 Remaining demonstrated reserve base in Illinois, January 1, 1996 (million short tons)

ఎం

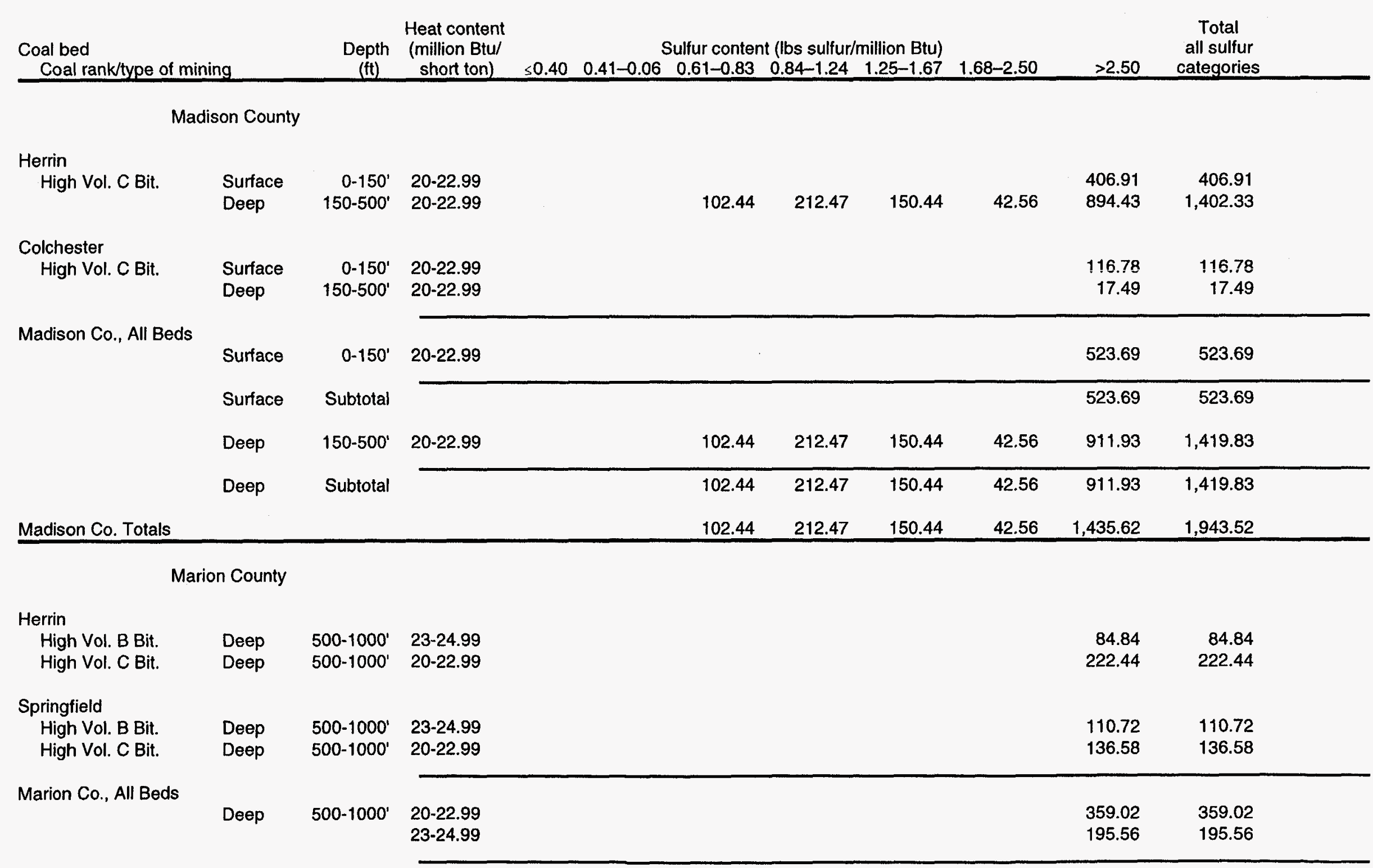


Appendix 4 Remaining demonstrated reserve base in Illinois, January 1, 1996 (million short tons)

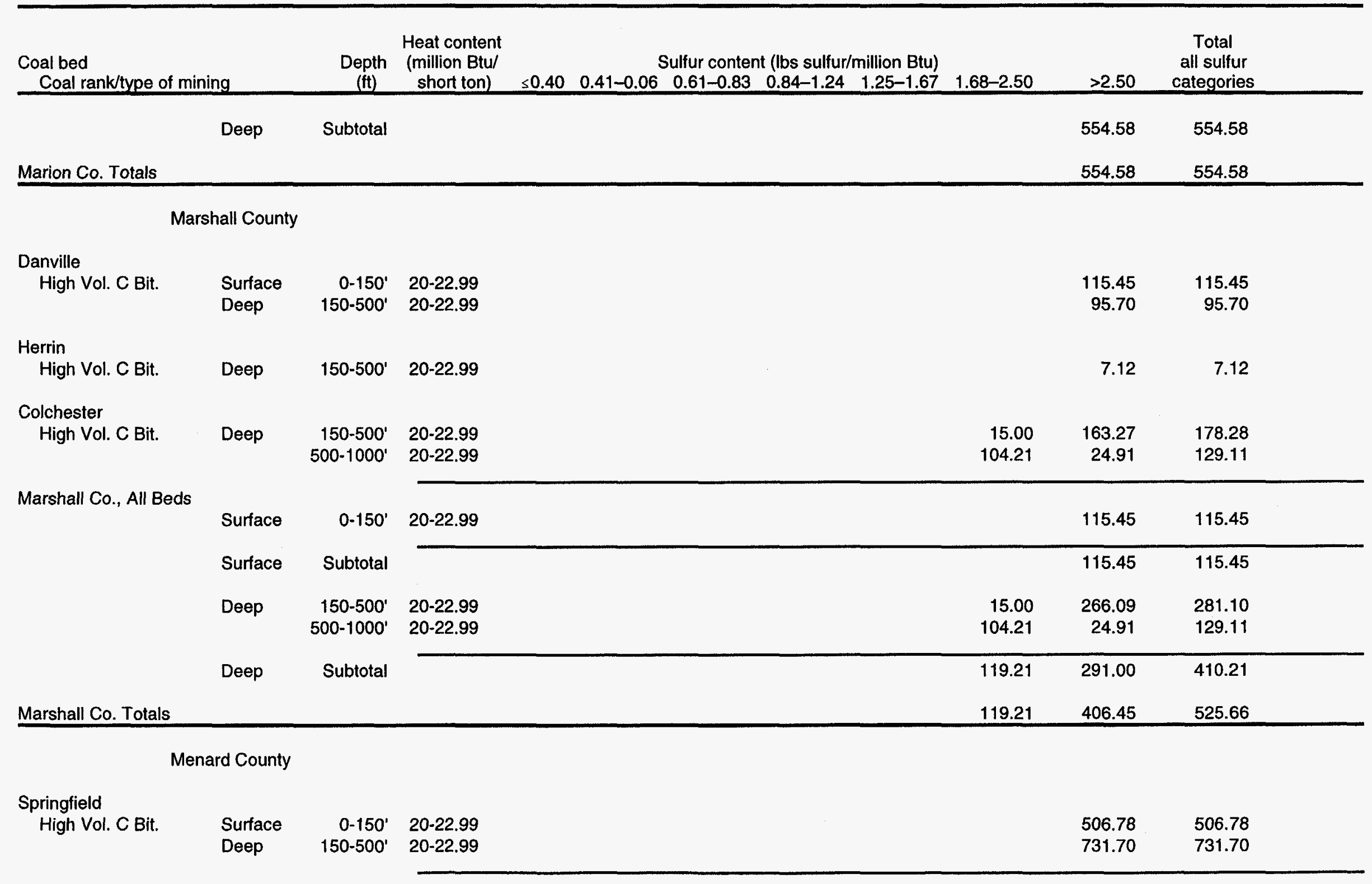


Appendix 4 Remaining demonstrated reserve base in Illinois, January 1, 1996 (million short tons)

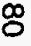

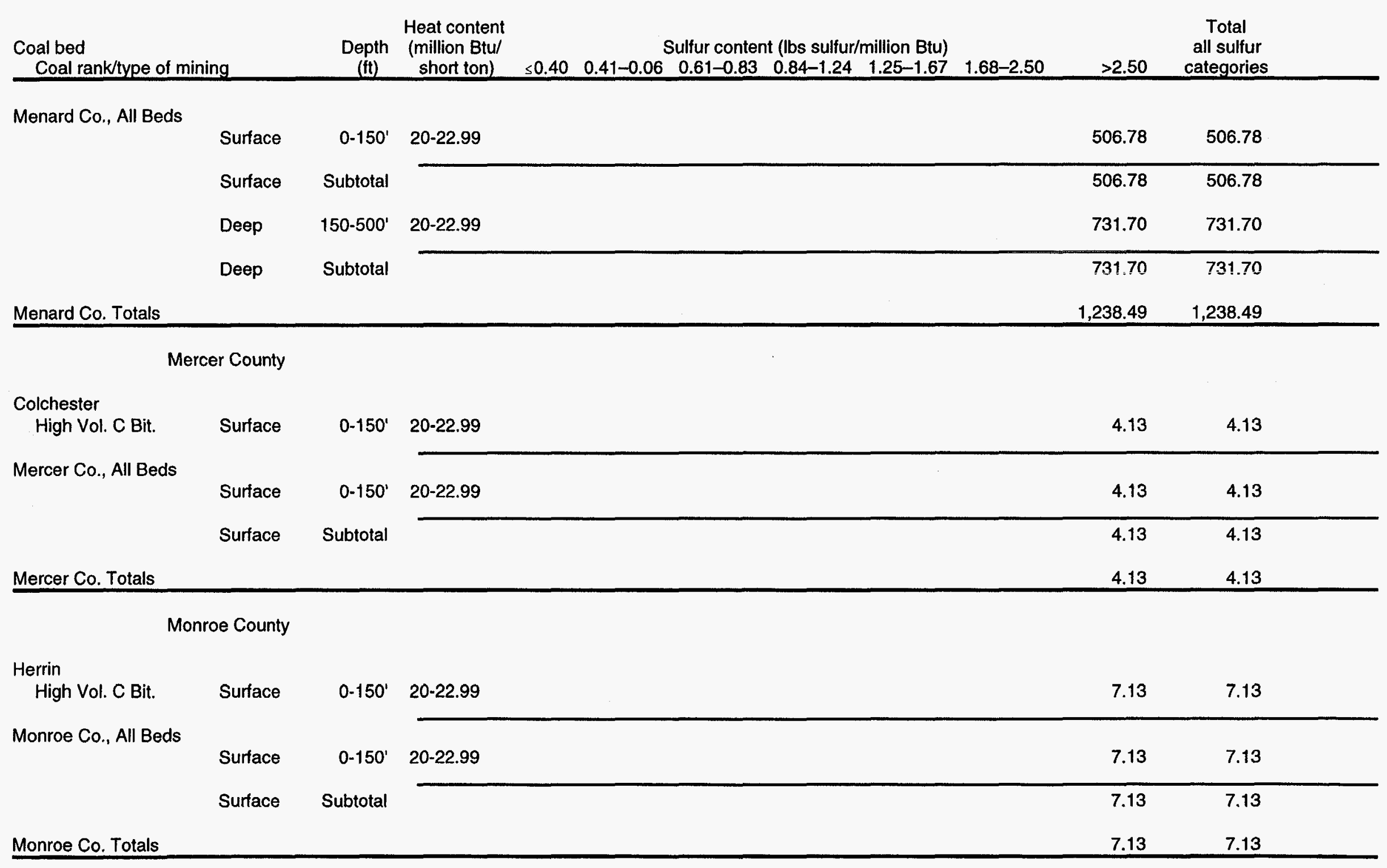




\begin{tabular}{|c|c|c|c|c|c|c|c|c|c|c|c|}
\hline \multicolumn{2}{|c|}{$\begin{array}{l}\text { Coal bed } \\
\text { Coal rank/type of mining }\end{array}$} & $\begin{array}{l}\text { Depth } \\
\text { (ft) }\end{array}$ & $\begin{array}{l}\text { Heat content } \\
\text { (million Btu/ } \\
\text { short ton) }\end{array}$ & \multicolumn{6}{|c|}{$\begin{array}{l}\text { Sulfur content (lbs sulfur/million Btu) } \\
\end{array}$} & \multicolumn{2}{|r|}{$\begin{array}{c}\text { Total } \\
\text { all sulfur } \\
\text { categories }\end{array}$} \\
\hline \multicolumn{12}{|c|}{ Montgomery County } \\
\hline \multicolumn{12}{|l|}{ Danville } \\
\hline High Vol. C Bit. & Deep & $500-1000^{\prime}$ & $20-22.99$ & & & & & & & 51.61 & 51.61 \\
\hline \multicolumn{12}{|l|}{ Herrin } \\
\hline High Vol. C Bit. & Deep & $\begin{array}{r}150-500^{\prime} \\
500-1000^{\prime}\end{array}$ & $\begin{array}{l}20-22.99 \\
20-22.99\end{array}$ & & & 87.73 & 34.10 & 69.00 & 50.32 & $\begin{array}{l}1,926.52 \\
1,615.88\end{array}$ & $\begin{array}{l}2,167.68 \\
1,615.88\end{array}$ \\
\hline \multicolumn{12}{|l|}{ Houchin Creek } \\
\hline \multicolumn{12}{|l|}{ Colchester } \\
\hline High Vol. C Bit. & Deep & $500-1000^{\prime}$ & $20-22.99$ & & & & & & & 176.31 & 176.31 \\
\hline \multicolumn{12}{|l|}{ Wiley } \\
\hline High Vol. C Bit. & Deep & $500-1000^{\prime}$ & $20-22.99$ & & & & & & & 78.09 & 78.09 \\
\hline \multicolumn{12}{|l|}{ Litchfield } \\
\hline High Vol. C Bit. & Deep & $500-1000^{\prime}$ & $20-22.99$ & & & & & & & 183.15 & 183.15 \\
\hline \multicolumn{12}{|c|}{ Montgomery Co., All Beds } \\
\hline & Deep & $\begin{array}{r}150-500^{\prime} \\
500-1000^{\prime}\end{array}$ & $\begin{array}{l}20-22.99 \\
20-22.99\end{array}$ & & & 87.73 & 34.10 & 69.00 & 50.32 & $\begin{array}{l}2,023.54 \\
2,105.04\end{array}$ & $\begin{array}{l}2,264.69 \\
2,105.04\end{array}$ \\
\hline & Deep & Subtotal & & & & 87.73 & 34.10 & 69.00 & 50.32 & $4,128.57$ & $4,369.73$ \\
\hline Montgomery $\mathrm{Co}$. To & & & & & 87.73 & 34.10 & 69.00 & 50.32 & $4,128.57$ & $4,369.73$ & \\
\hline
\end{tabular}


Appendix 4 Remaining demonstrated reserve base in Illinois, January 1, 1996 (million short tons)

$\stackrel{\infty}{N}$

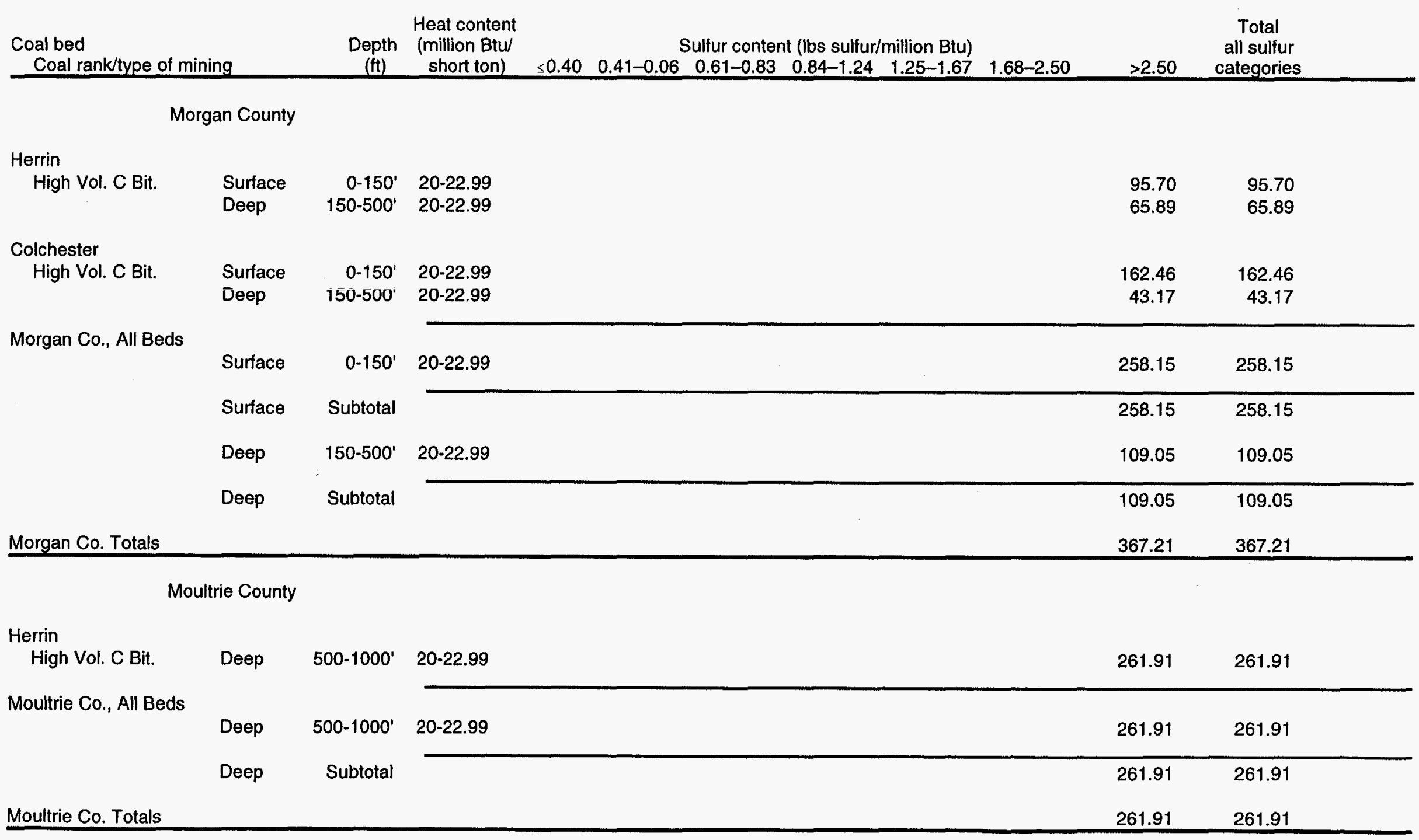


Appendix 4 Remaining demonstrated reserve base in Illinois, January 1, 1996 (million short tons)

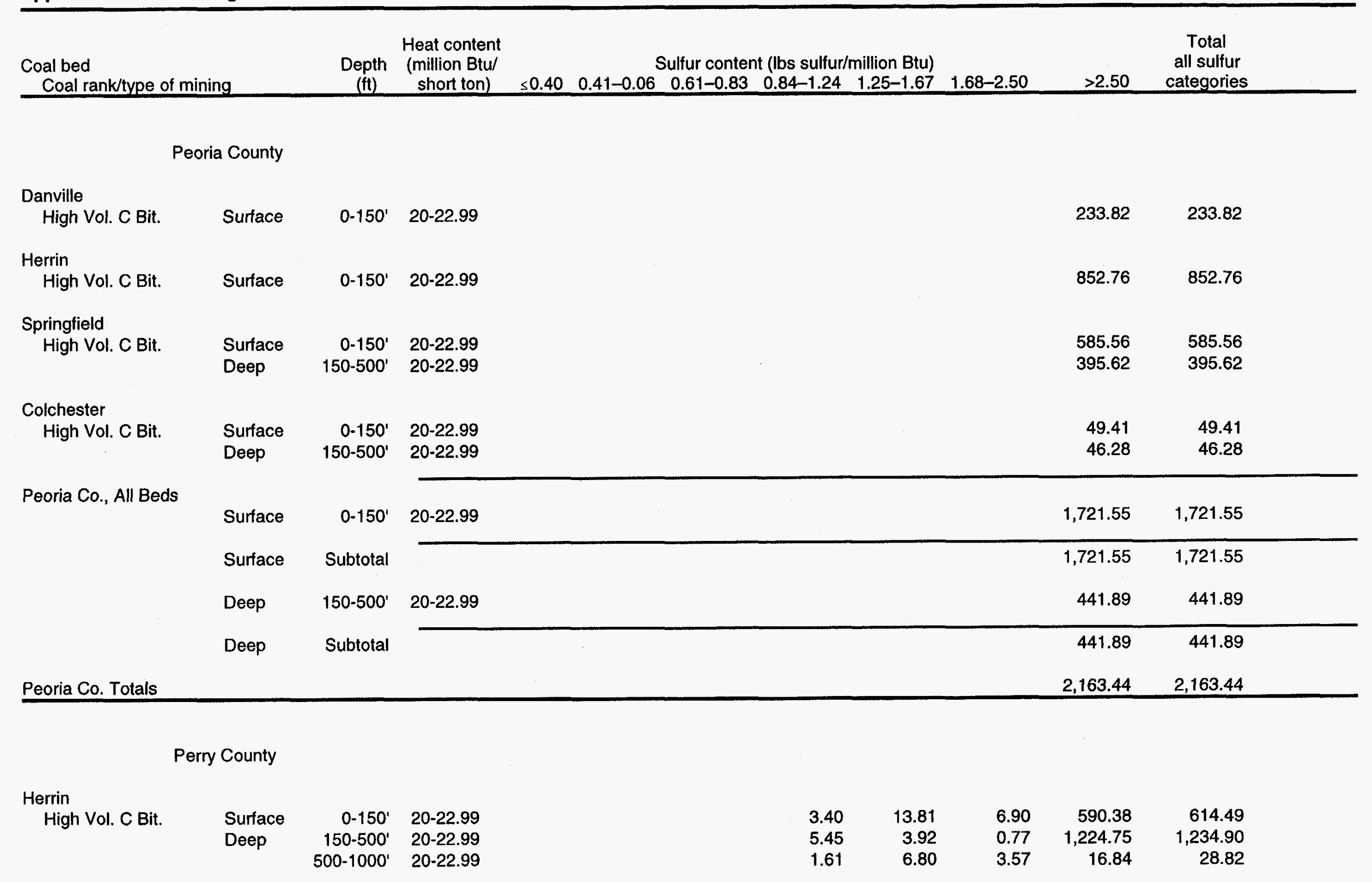


Appendix 4 Remaining demonstrated reserve base in Illinois, January 1, 1996 (million short tons)

$\stackrel{\infty}{\ddagger}$

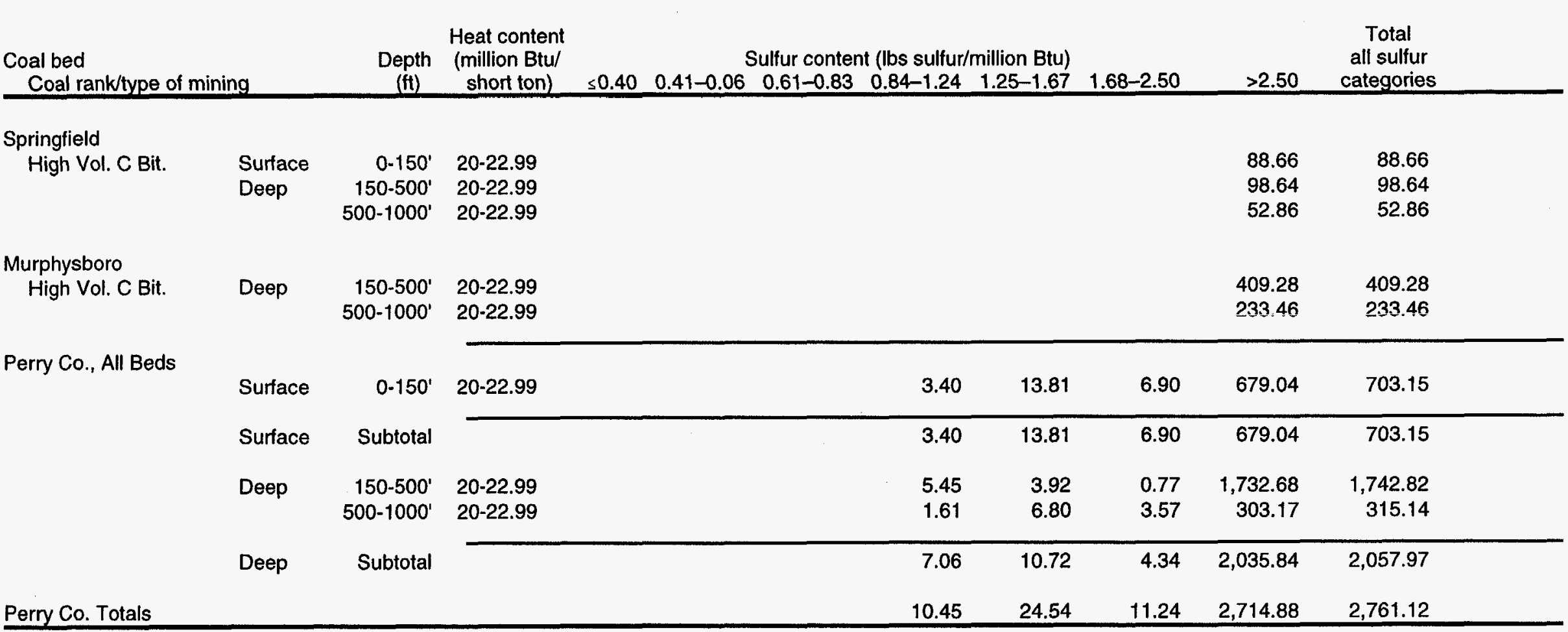

Pike County

Colchester

High Vol. C Bit.

Surface

$0-150^{\prime} \quad 20-22.99$

116.62

116.62

Pike Co., All Beds

Surface

$-$

116.62

116.62

Surface

$0-150^{\prime} \quad 20-22.99$

116.62

116.62

Pike Co. Totals

116.62

116.62 
Appendix 4 Remaining demonstrated reserve base in Illinois, January 1, 1996 (million short tons)

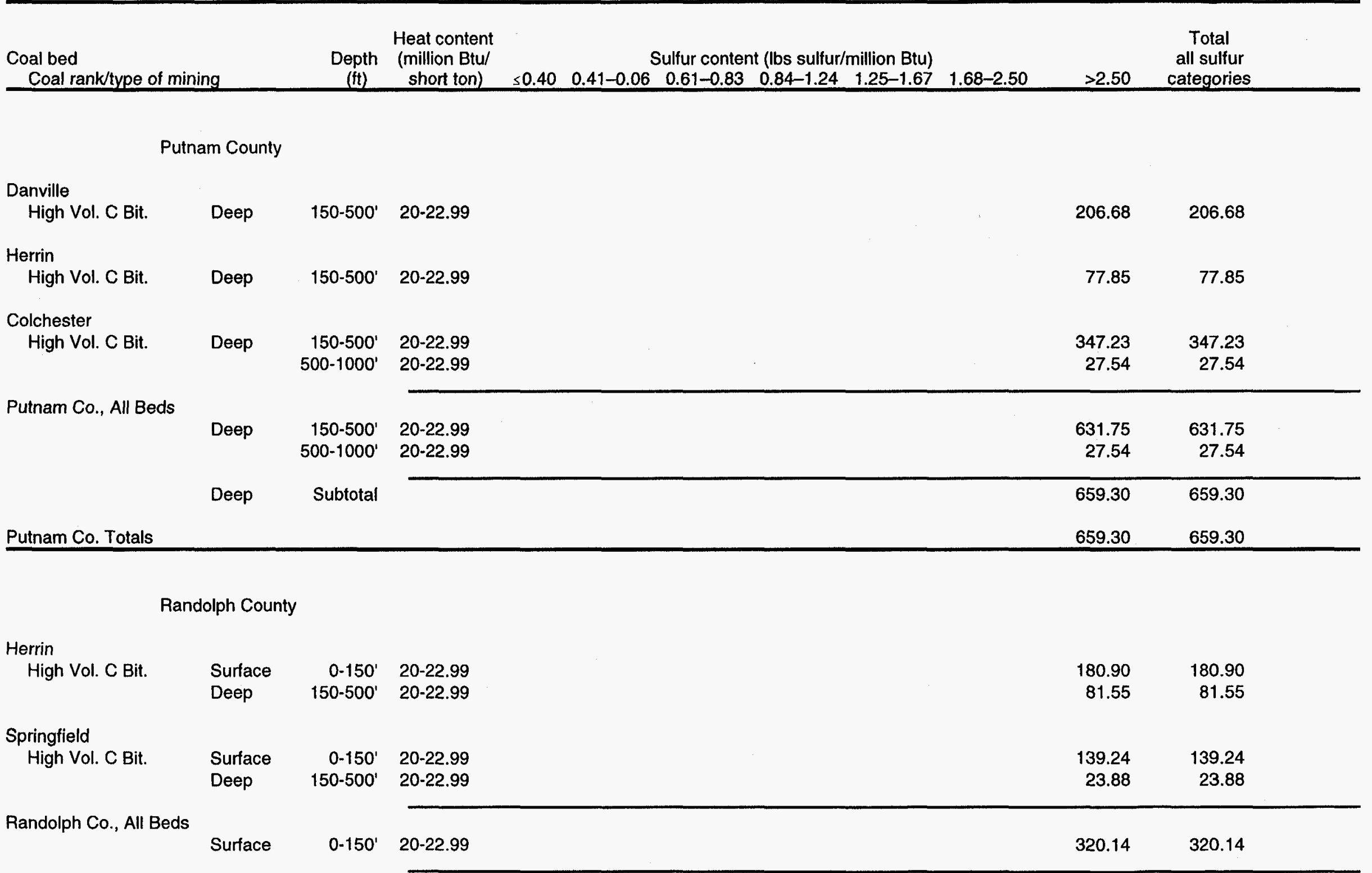


Appendix 4 Remaining demonstrated reserve base in Illinois, January 1, 1996 (million short tons)

吊

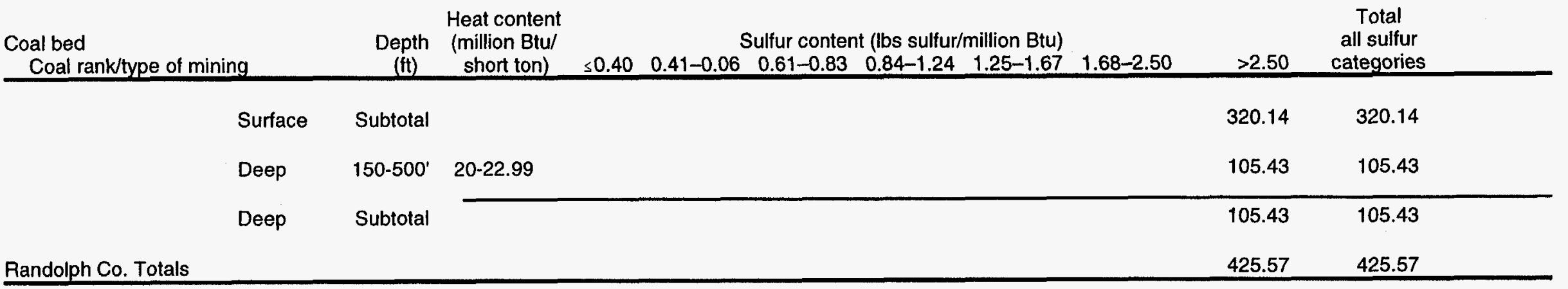

\section{Richland County}

Calhoun

High Vol. C Bit. Surface

Herrin

High Vol. B Bit. Deep 500-1000' 23-24.99

$>1000^{\prime} \quad 23-24.99$

$28.09 \quad 28.09$

Springfield

High Vol. B Bit.

Deep

500-1000' 23-24.99

$>1000^{\prime} \quad 23-24.99$

$180.76 \quad 180.76$

Richland Co., All Beds

\begin{tabular}{lrrrrr} 
Surface & $0-150^{\prime}$ & $20-22.99$ & 6.60 & 6.60 \\
\cline { 3 - 6 } & & & & 6.60 & 6.60 \\
Surface & Subtotal & & 28.37 & 28.37 \\
Deep & $500-1000^{\prime}$ & $23-24.99$ & 358.38 & 358.38 \\
& $>1000^{\prime}$ & $23-24.99$ & 386.75 & 386.75 \\
\cline { 3 - 6 } Deep & Subtotal & & 393.35 & 393.35 \\
& & & &
\end{tabular}


Appendix 4 Remaining demonstrated reserve base in Illinois, January 1, 1996 (million short tons)

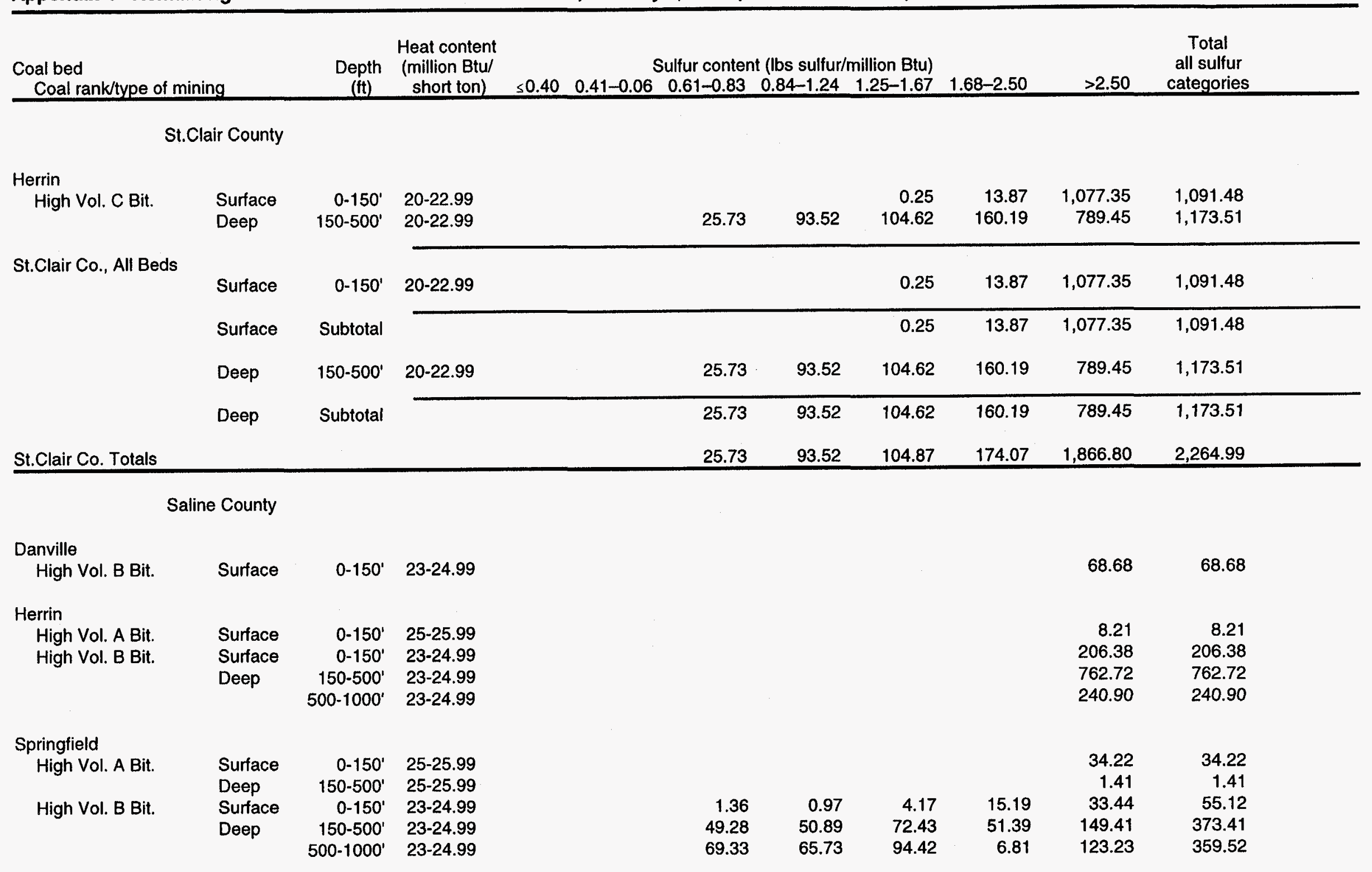


Appendix 4 Remaining demonstrated reserve base in Illinois, January 1, 1996 (million short tons)

œ

\begin{tabular}{|c|c|c|c|c|c|c|c|c|c|c|c|}
\hline \multicolumn{2}{|c|}{$\begin{array}{l}\text { Coal bed } \\
\text { Coal ranktype of mining }\end{array}$} & $\begin{array}{c}\text { Depth } \\
(f t)\end{array}$ & $\begin{array}{l}\text { Heat content } \\
\text { (million Btu/ } \\
\text { short ton) } \\
\end{array}$ & \multicolumn{5}{|c|}{\begin{tabular}{ccccc} 
& \multicolumn{4}{c}{ Sulfur content (lbs sulfur/million Btu) } \\
$\leq 0.40$ & $0.41-0.06$ & $0.61-0.83$ & $0.84-1.24$ & $1.25-1.67$ \\
\end{tabular}} & $1.68-2.50$ & \multicolumn{2}{|r|}{$\begin{array}{c}\text { Total } \\
\text { all sulfur } \\
\text { categories }\end{array}$} \\
\hline \multicolumn{12}{|l|}{ Houchin Creek } \\
\hline High Vol. B Bit. & Deep & 150-500' & $23-24.99$ & & & & & & & 12.69 & 12.69 \\
\hline \multicolumn{12}{|l|}{ DeKoven } \\
\hline \multirow[t]{3}{*}{ High Vol. A Bit. } & Surface & $0-150^{\prime}$ & $25-25.99$ & & & & & & & 47.45 & 47.45 \\
\hline & Deep & $150-500^{\prime}$ & $25-25.99$ & & & & & & & 187.10 & 187.10 \\
\hline & & $500-1000^{\circ}$ & $25-25.99$ & & & & & & & 6.83 & 6.83 \\
\hline \multirow[t]{2}{*}{ High Vol. B Bit. } & Deep & $150-500^{\prime}$ & 23-24.99 & & & & & & & 31.21 & 31.21 \\
\hline & & $500-1000^{\prime}$ & $23-24.99$ & & & & & & & 209.12 & 209.12 \\
\hline \multicolumn{12}{|l|}{ Davis } \\
\hline \multirow[t]{3}{*}{ High Vol. A Bit. } & Surface & $0-150^{\prime}$ & $25-25.99$ & & & & & & & 70.91 & 70.91 \\
\hline & Deep & $150-500^{\prime}$ & $25-25.99$ & & & & & & & 257.52 & 257.52 \\
\hline & & $500-1000^{\prime}$ & $25-25.99$ & & & & & & & 10.15 & 10.15 \\
\hline \multirow[t]{2}{*}{ High Vol. B Bit. } & Deep & $150-500^{\prime}$ & $23-24.99$ & & & & & & & 45.15 & 45.15 \\
\hline & & $500-1000^{\prime}$ & $23-24.99$ & & & & & & & 401.13 & 401.13 \\
\hline \multirow[t]{8}{*}{ Saline Co., All Beds } & & & & & & & & & & & \\
\hline & Surface & $0-150^{\prime}$ & $23-24.99$ & & & 1.36 & 0.97 & 4.17 & 15.19 & 308.49 & 330.18 \\
\hline & & & 25-25.99 & & & & & & & 160.79 & 160.79 \\
\hline & Surface & Subtotal & & & & 1.36 & 0.97 & 4.17 & 15.19 & 469.29 & 490.97 \\
\hline & Deep & $150-500^{\prime}$ & 23-24.99 & & & 49.28 & 50.89 & 72.43 & 51.39 & $1,001.19$ & $1,225.18$ \\
\hline & & & $23-24.99$ & & & 69.33 & 65.73 & 94.42 & 6.81 & 976.32 & $1,212.61$ \\
\hline & & & $25-25.99$ & & & & & & & 16.99 & 16.99 \\
\hline & Deep & Subtotal & & & & 118.61 & 116.63 & 166.85 & 58.20 & $2,440.53$ & $2,900.82$ \\
\hline \multicolumn{2}{|l|}{ Saline Co. Totals } & & & & & 119.97 & 117.59 & 171.01 & 73.39 & $2,909.82$ & $3,391.79$ \\
\hline
\end{tabular}


Appendix 4 Remaining demonstrated reserve base in Illinois, January 1, 1996 (million short tons)

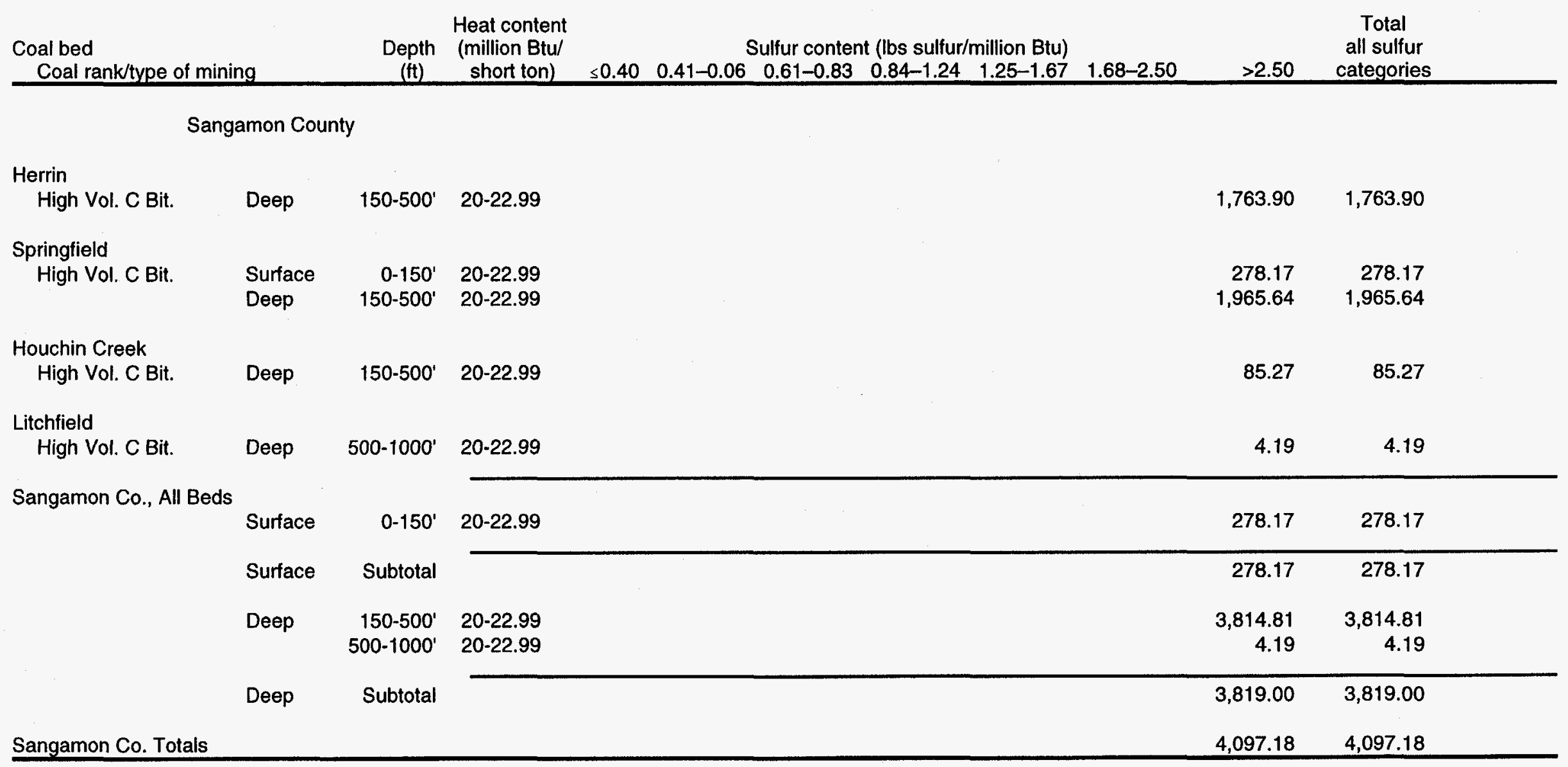

Schuyler County

Springfield 
Appendix 4 Remaining demonstrated reserve base in Illinois, January 1, 1996 (million short tons)

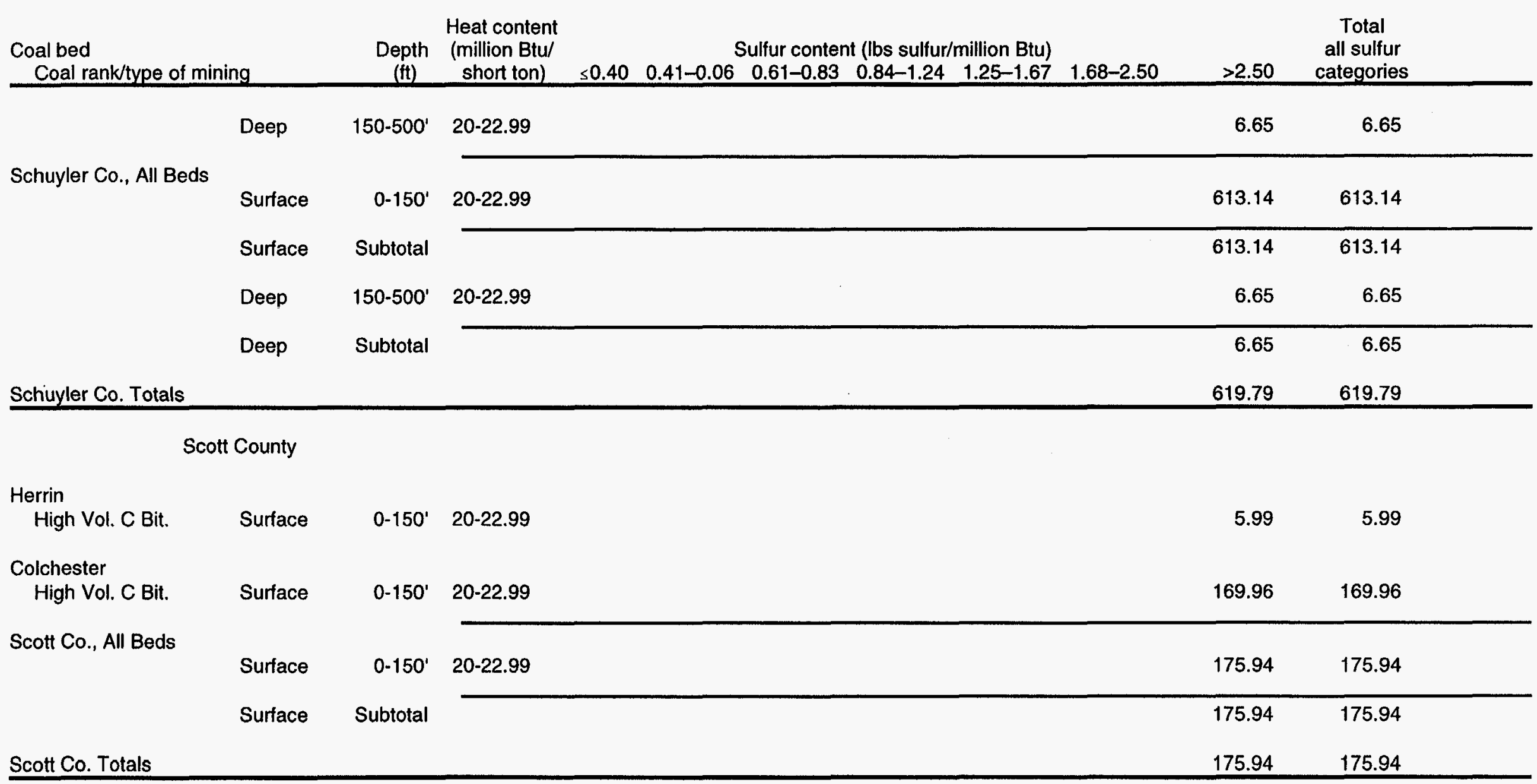

Shelby County

Trowbridge

High Vol. C Bit.

Surface

$0-150^{\prime}<19.99$

Shelbyville High Vol. C Bit.

Surface 
Appendix 4 Remaining demonstrated reserve base in Illinois, January 1, 1996 (million short tons)

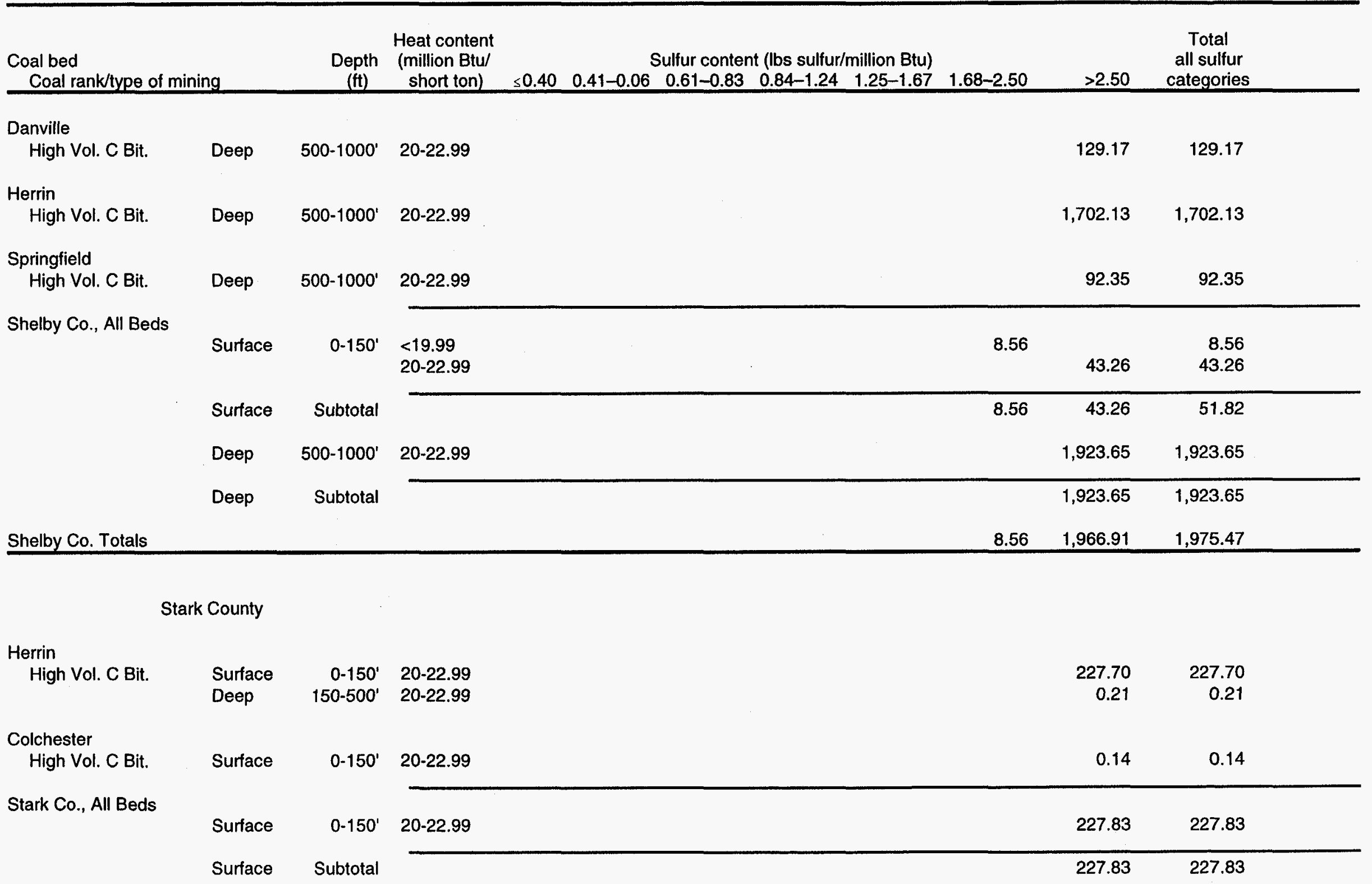


Appendix 4 Remaining demonstrated reserve base in Illinois, January 1, 1996 (million short tons)

\&

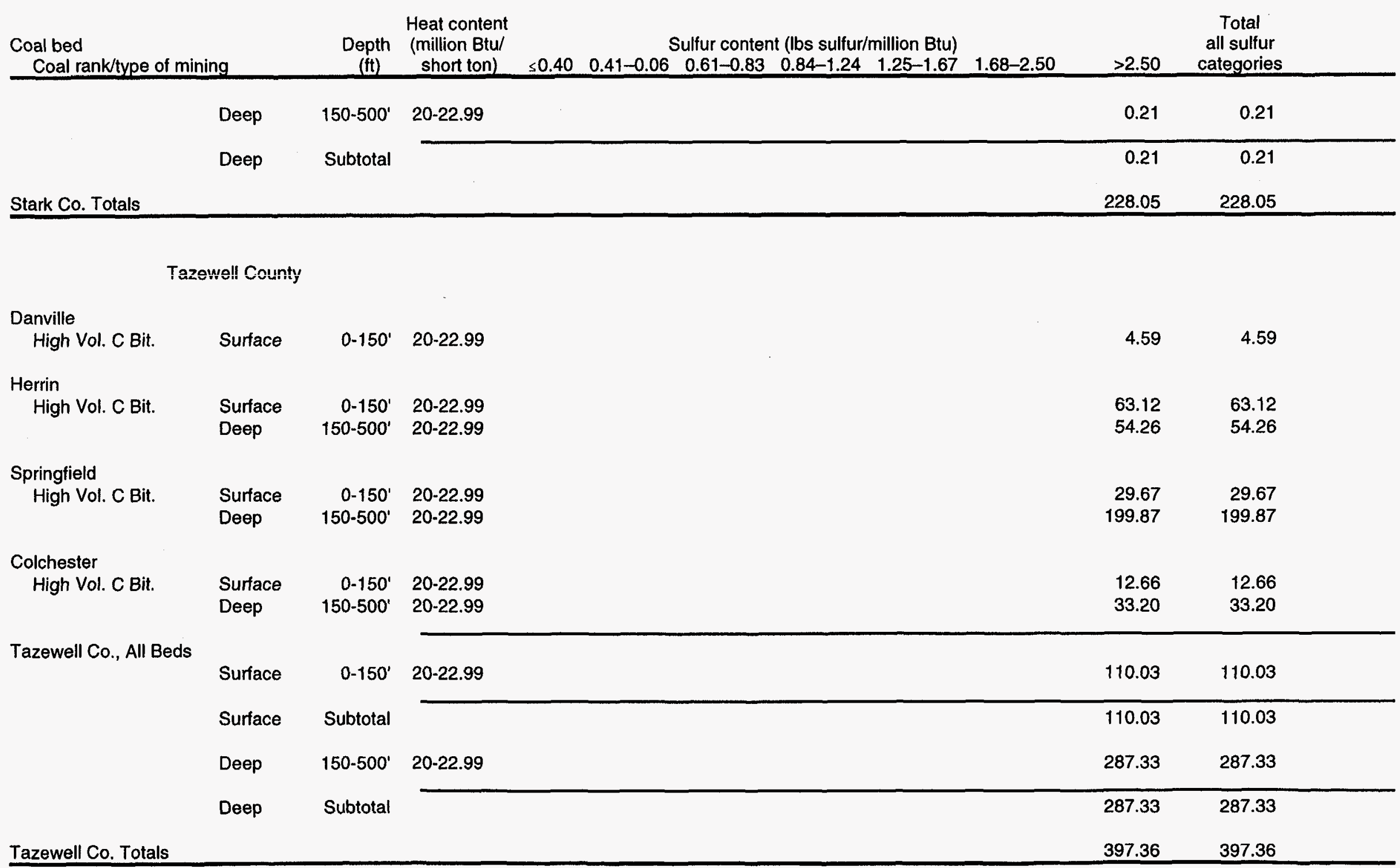


Appendix 4 Remaining demonstrated reserve base in lllinois, January 1, 1996 (million short tons)

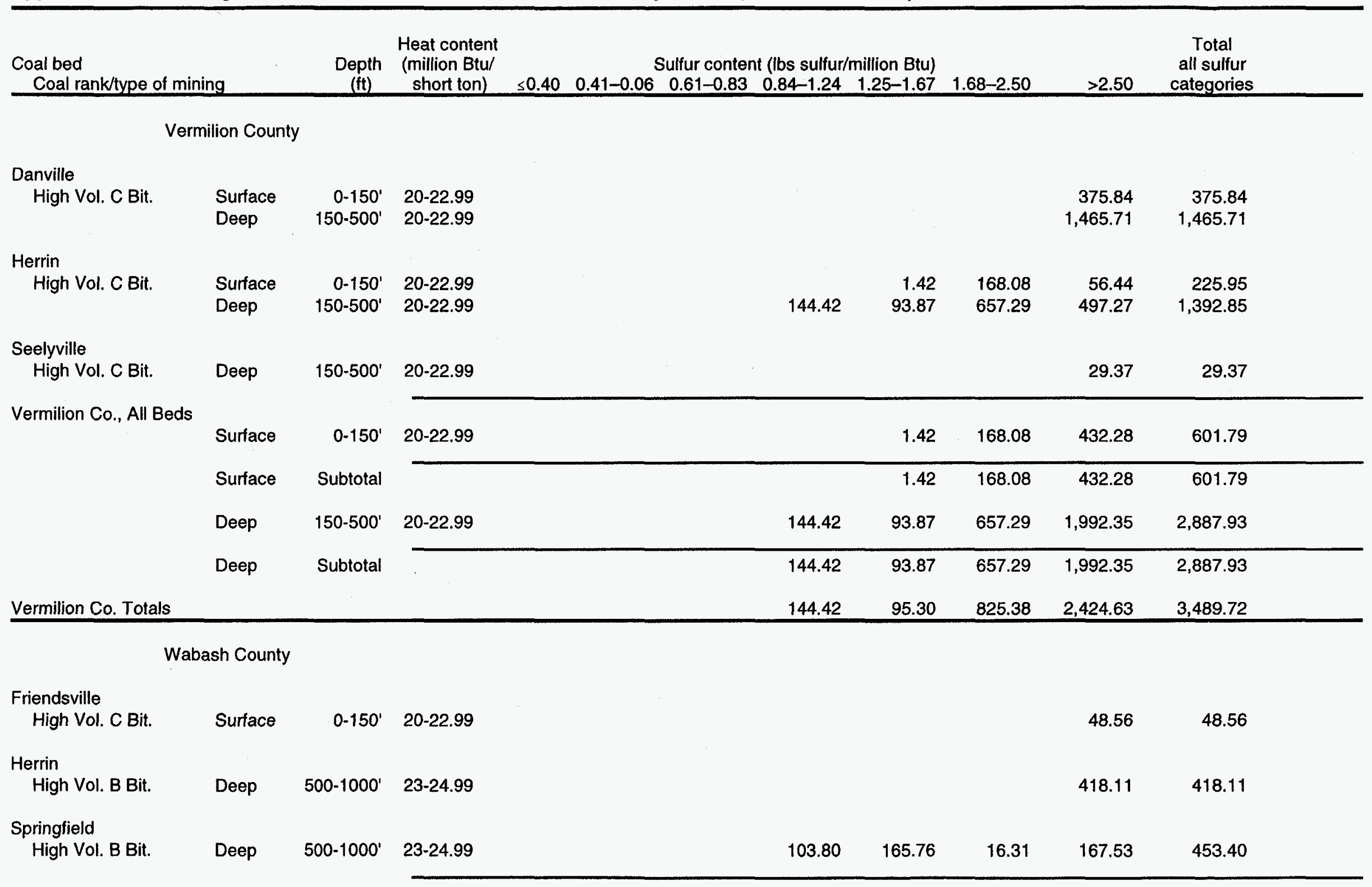


Appendix 4 Remaining demonstrated reserve base in Illinois, January 1, 1996 (million short tons)

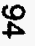

\begin{tabular}{|c|c|c|c|c|c|c|c|c|c|c|c|}
\hline \multicolumn{2}{|l|}{$\begin{array}{l}\text { Coal bed } \\
\text { Coal rank/type of mining }\end{array}$} & $\begin{array}{l}\text { Depth } \\
\text { (ft) }\end{array}$ & $\begin{array}{c}\text { Heat content } \\
\text { (million Btu/ } \\
\text { short ton) }\end{array}$ & \multicolumn{6}{|c|}{ Sulfur content (Ibs sulfur/million Btu) } & \multicolumn{2}{|r|}{$\begin{array}{c}\text { Total } \\
\text { all sulfur } \\
\text { categories }\end{array}$} \\
\hline \multicolumn{12}{|l|}{ Wabash Co., All Beds } \\
\hline & Surface & $0-150^{\prime}$ & 20-22.99 & & & & & & & 48.56 & 48.56 \\
\hline & Surface & Subtotal & & & & & & & & 48.56 & 48.56 \\
\hline & Deep & $500-1000^{\prime}$ & $23-24.99$ & & & & 103.80 & 165.76 & 16.31 & 585.63 & 871.51 \\
\hline & Deep & Subtotal & & & & & 103.80 & 165.76 & 16.31 & 585.63 & 871.51 \\
\hline Wabash Co. Totals & & & & & & & 103.80 & 165.76 & 16.31 & 634.19 & 920.06 \\
\hline
\end{tabular}

\section{Warren County}

Springfield

$\begin{array}{lllll}\text { High Vol. C Bit. } \quad \text { Surface } & 0-150^{\prime} & 20-22.99 & 0.79 & 0.79\end{array}$

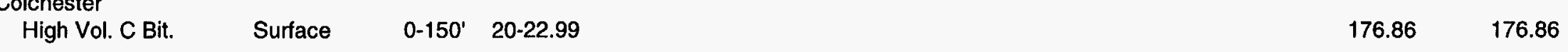

Warren Co., All Beds

\begin{tabular}{lrrrrr} 
Surface & $0-150^{\prime}$ & $20-22.99$ & 177.65 & 177.65 \\
\cline { 3 - 6 } Surface & Subtotal & 177.65 & 177.65 \\
& & & 177.65 & 177.65 \\
\hline
\end{tabular}

Warren Co. Totals

Washington County

Herrin

$\begin{array}{llrlrr}\text { High Vol. C Bit. } & \text { Surface } & 0-150^{\prime} & 20-22.99 & 9.26 \\ & \text { Deep } & 150-500^{\prime} & 20-22.99 & 3.26 & 3,288.45 \\ & & 500-1000^{\prime} & 20-22.99 & 384.01 & 384.01\end{array}$


Appendix 4 Remaining demonstrated reserve base in Illinois, January 1, 1996 (million short tons)

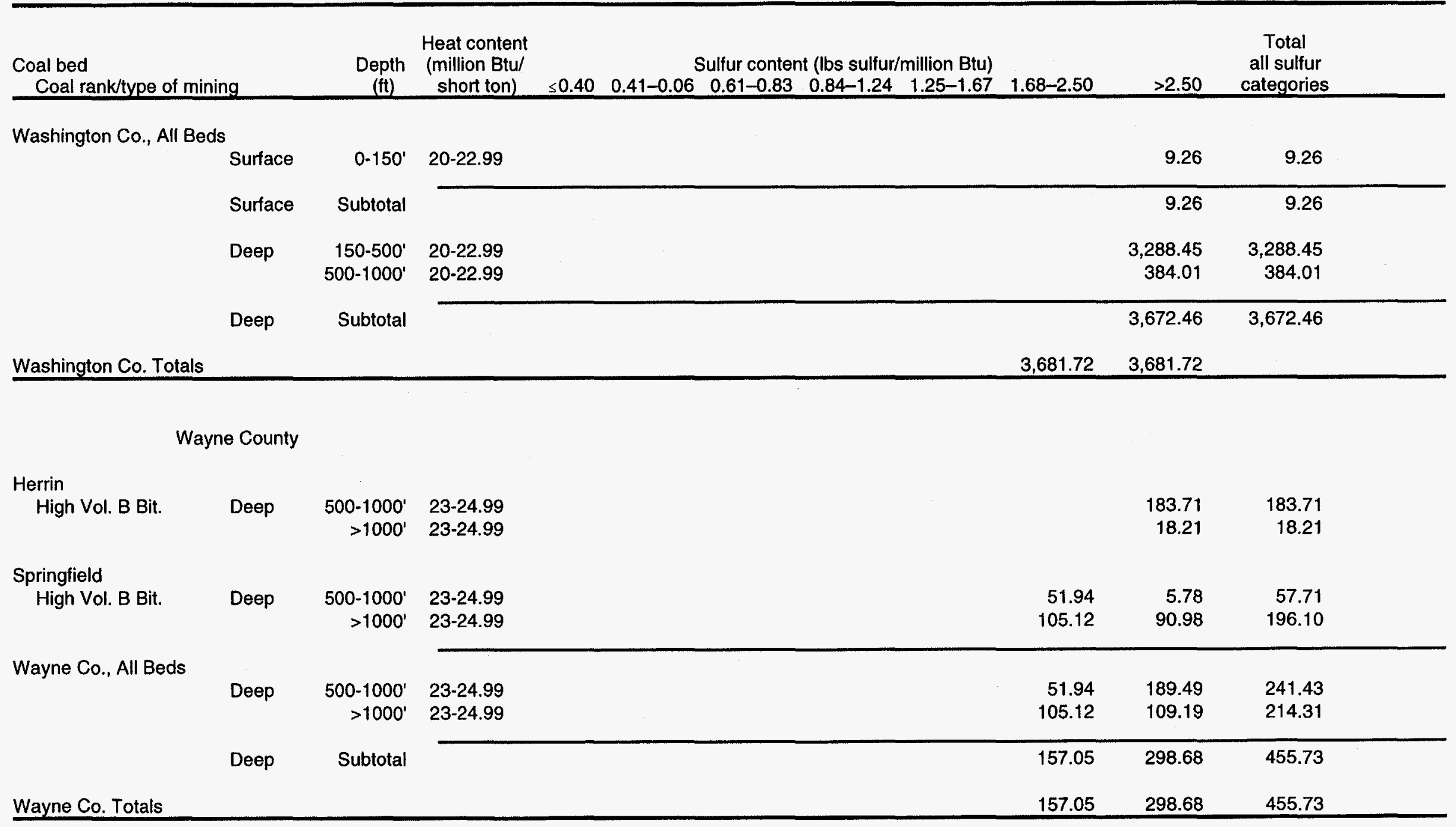


Appendix 4 Remaining demonstrated reserve base in Illinois, January 1, 1996 (million short tons)

$\mathscr{8}$

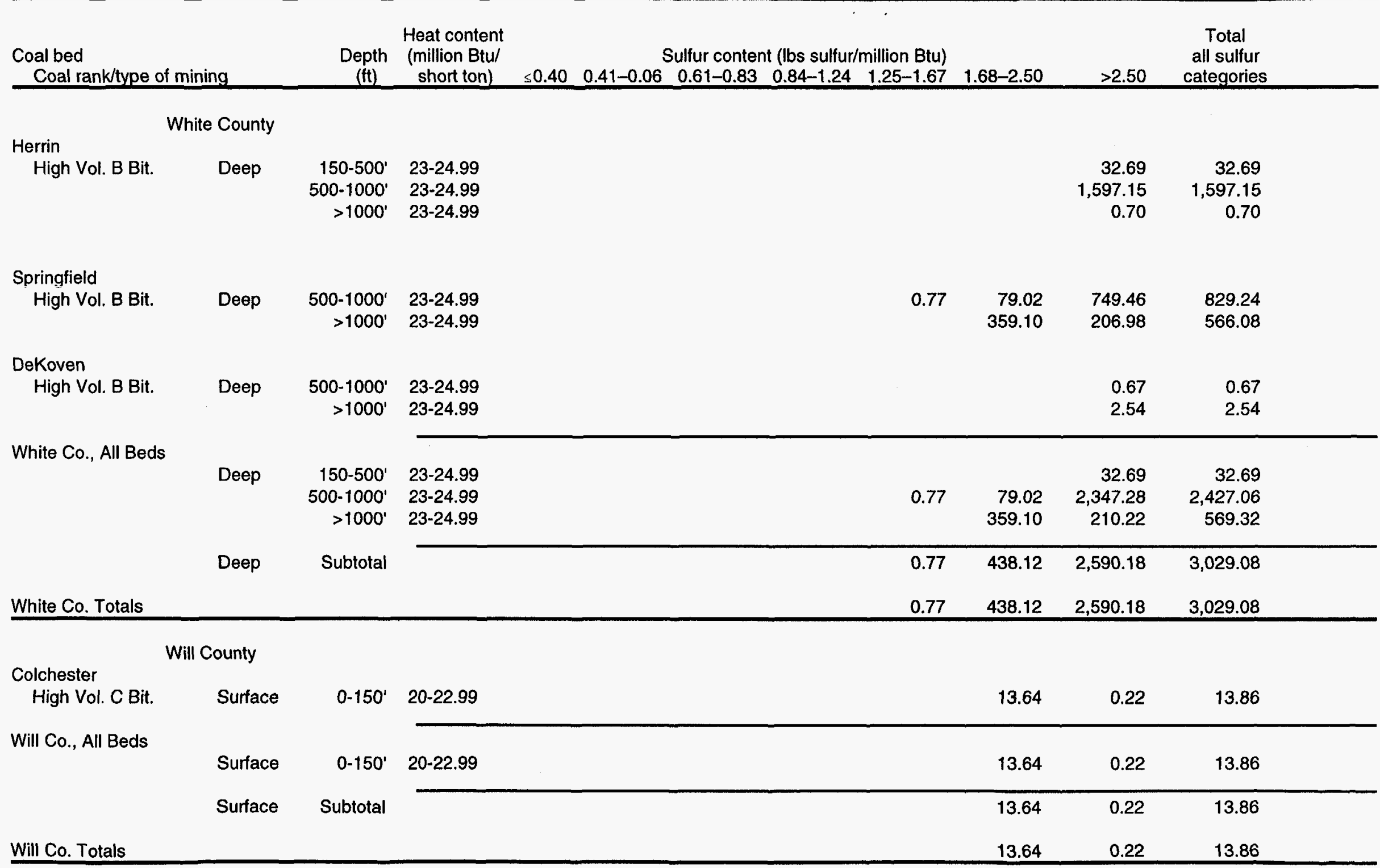


Appendix 4 Remaining demonstrated reserve base in Illinois, January 1, 1996 (million short tons)

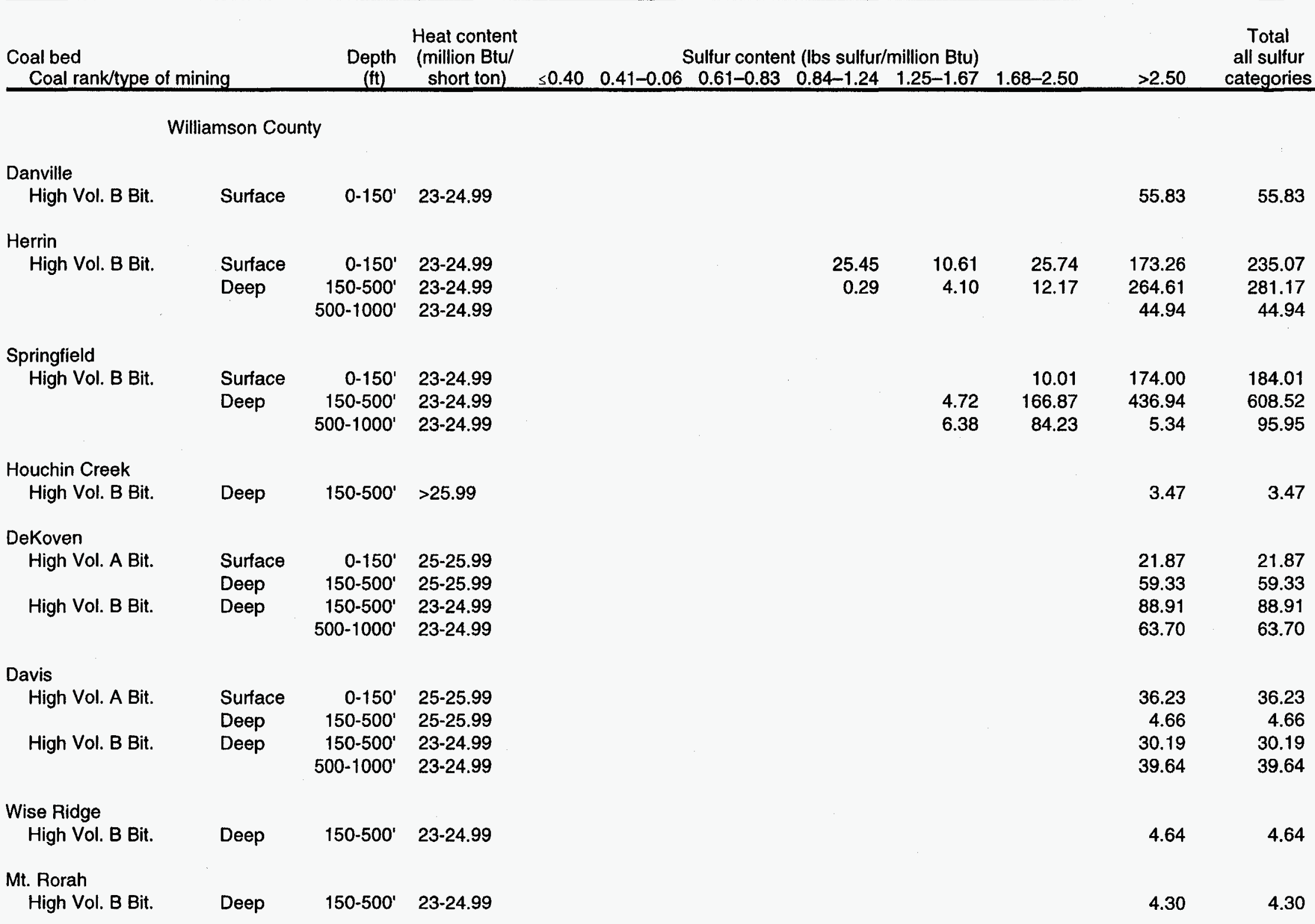


Appendix 4 Remaining demonstrated reserve base in llinois, January 1, 1996 (million short tons)

$\mathscr{\infty}$

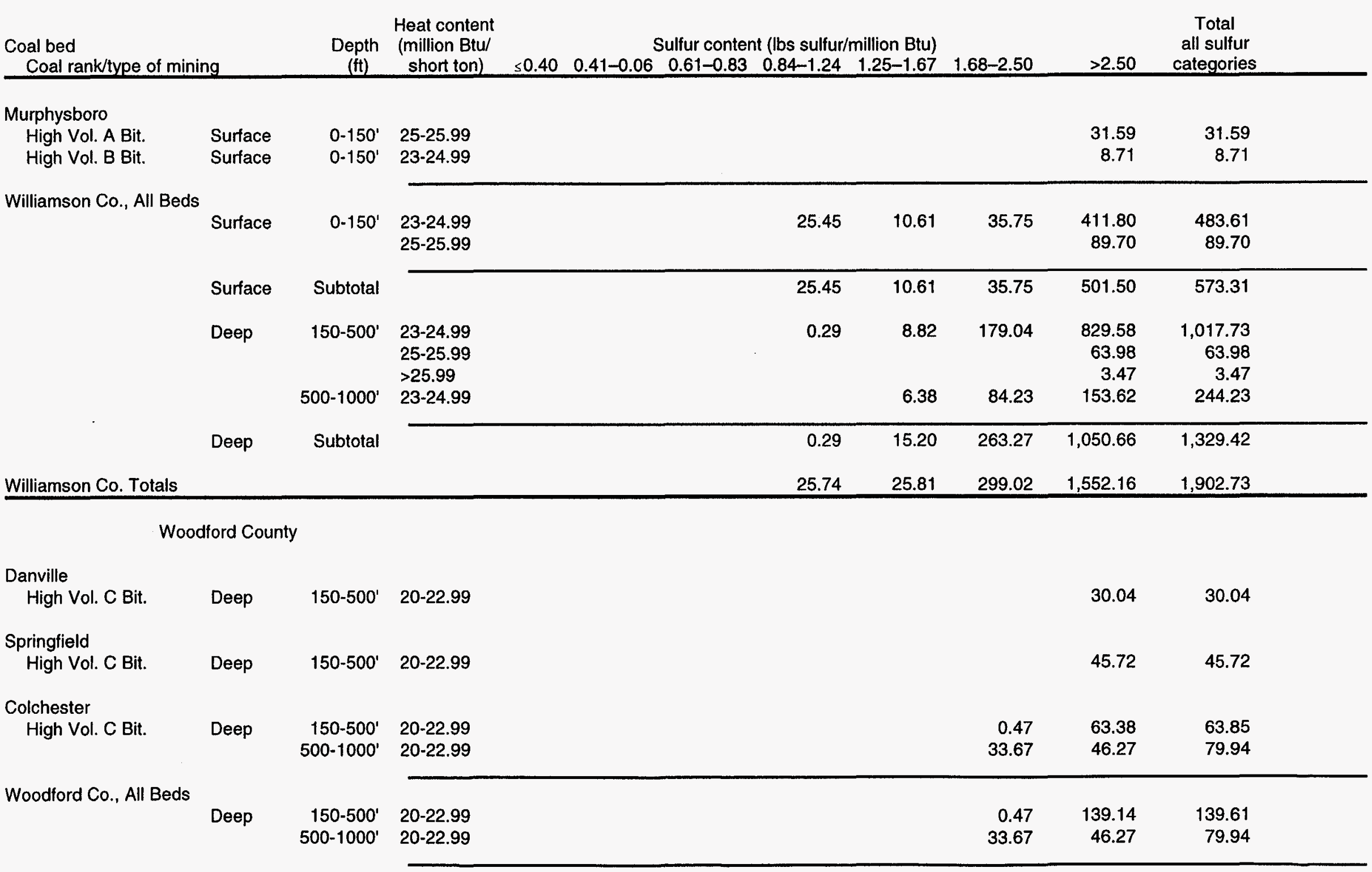




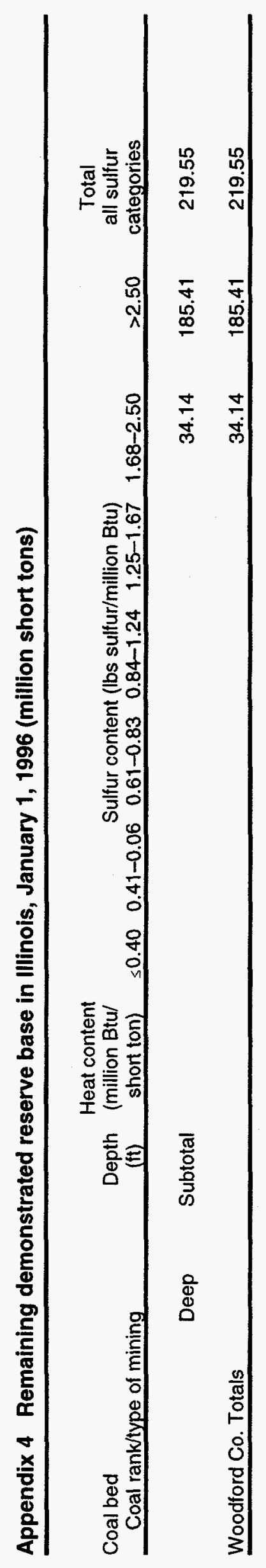




\section{APPENDIX 5 Formats of digital files of demonstrated reserves provided to the Energy Information Administration}

The EIA will be provided with three digital files, all with the same format and a fixed record length of 123 characters. The three files are (1) identified resources and demonstrated reserves, (2) accessible reserves, and (3) recoverable reserves. Data will be aggregated to the county level by seam. For each seam in a county, there will be one or more records, depending upon the different combinations of reliability, thickness, depth, Btu, and rank. The layout of each record is described below.

15 items: starting in position 1

\begin{tabular}{|c|c|c|c|c|c|}
\hline Col & Item name & Wiclth & Type & N. Dec & Explanation \\
\hline 1 & COUNTY & 3 & 1 & - & County FIPS code \\
\hline 4 & SEAM & 4 & 1 & - & ISGS seam code \\
\hline 8 & RELIABILITY & 1 & 1 & - & ISGS reliability classification \\
\hline 9 & THICK & 3 & 1 & - & Thickness in inches \\
\hline 12 & DEPTH & 4 & 1 & - & Depth category \\
\hline 16 & BTU & 5 & $\mathbf{N}$ & 2 & Btu category \\
\hline 21 & RANK & 1 & C & - & $\operatorname{Rank}(A, B$, or $C)$ \\
\hline 22 & S.40 & 10 & 1 & - & Tonnage, Ibs $S<0.40 /$ million Btu \\
\hline 32 & S. 60 & 10 & 1 & - & Tonnage, Ibs S $0.41-0.60$ /million Btu \\
\hline 42 & S.83 & 10 & 1 & - & Tonnage, Ibs S $0.61-0.83 /$ million Btu \\
\hline 52 & S1.24 & 10 & 1 & - & Tonnage, Ibs S $0.83-1.24 /$ million Btu \\
\hline 62 & S1.67 & 10 & $\mathbf{I}$ & - & Tonnage, Ibs S 1.24-1.67/million Btu \\
\hline 72 & S2.5 & 10 & 1 & - & Tonnage, Ibs S $1.67-2.5 /$ million Btu \\
\hline 82 & S2.5+ & 10 & 1 & - & Tonnage, Ibs $S>2.5 /$ million Btu \\
\hline 92 & ALL-SUL & 10 & 1 & - & Tonnage, all sulfur categories \\
\hline 102 & AVE-RATIO & 4 & $N$ & 1 & Average stripping ratio \\
\hline 106 & MAX-RATIO & 4 & $\mathbf{N}$ & 1 & Maximum stripping ratio \\
\hline 110 & MIN-THICK & 3 & 1 & - & Minimum thickness in inches \\
\hline 113 & MAX-THICK & 3 & 1 & - & Maximum thickness in inches \\
\hline 116 & MIN-DEPTH & 4 & I & - & Minimum depth in feet \\
\hline 120 & MAX-DEPTH & 4 & 1 & - & Maximum depth in feet \\
\hline
\end{tabular}

\begin{tabular}{ll}
\multicolumn{2}{c}{ ISGS seam codes } \\
\hline 1670 & Trowbridge \\
1750 & Calhoun \\
1760 & Shelbyville \\
1780 & Opdyke \\
1790 & Loudon \\
1800 & Belle Rive \\
1910 & Bristol Hill \\
2490 & Danville \\
2610 & Jamestown \\
2660 & Herrin \\
2790 & Springfield \\
2840 & Houchin Creek \\
2940 & Survant \\
3020 & Colchester \\
3030 & Mt. Rorah \\
3170 & Seelyville \\
3210 & Dekoven \\
3240 & Wiley \\
3250 & Davis \\
3370 & Murphysboro \\
3490 & Rock Island \\
3500 & Litchfield \\
3510 & Assumption \\
\hline
\end{tabular}

\begin{tabular}{c} 
Item types \\
\hline$I=$ integer \\
$N=$ decimal \\
$C=$ character \\
\hline Reliability codes \\
\hline $3=$ measured \\
$1=$ indicated \\
$2=$ inferred \\
\hline
\end{tabular}

\begin{tabular}{c} 
Average depth categories $(\mathrm{ft})$ \\
\hline $50=\quad 0$ to 50 \\
$100=50$ to 100 \\
$150=100$ to 150 \\
$200=150$ to 200 \\
$250=200$ to 300 \\
$350=300$ to 400 \\
$450=400$ to 500 \\
$\quad \ldots$ etc.
\end{tabular}
Btu categories (million Btu/ton)

$19.00=15-19.99$
$21.50=20-22.99$
$24.00=23-24.99$
$25.50=25-25.99$




\section{APPENDIX 6 Procedures for revising estimates of coal resources}

The ISGS maps and database on coal resources and reserves in Illinois have been organized by county and seam. For counties for which significant new data were available, resource estimates were also revised on a seam and county basis.

The ISGS has typically mapped coal resources at a scale of 1:62,500. In most cases, this scale is well suited for the amount of data available (generally only a few points per square mile) and the variability in seam thickness. (The thickness of major Illinois coals is consistent over wide areas.) The areas revised for this project were gridded using a 1,000-foot spacing (see discussion under section on contouring) and contoured at a scale of 1:24,000.

Computer databases and mapping software are used extensively in the mapping process, particularly for representing data, merging layers of information, and tabulating tonnages. Computers have not replaced the requirement for geologic expertise and careful work in compiling and interpreting resource data. This appendix outlines the procedures used to revise coal resources for this study. In practice, the process is not routine; its success depends upon the geologist's ability to recognize miscorrelations between seams, to identify and reject imprecise or spurious drilling records, and to distinguish between genuine geologic trends and localized anomalies.

Revising resource estimates proceeds in three basic steps: (1) selecting the data, (2) contouring the thickness and depth, and (3) merging the contours with other data layers and calculating volumes.

\section{Selection of Data}

The ISGS maintains paper files and a computer database of stratigraphic records from boreholes, outcrops, and mine exposures. The measurements and lithologies were recorded by coal companies or observed by ISGS geologists. Approximately half the records are proprietary and can only be used by ISGS staff as long as specific point locations and thickness measurements are not disclosed.

All stratigraphic correlations in the computer database have been made by ISGS staff. Although the computer database is not complete for all counties in the state, it was completed for the counties updated for this project.

Data selection begins by extracting from the database all points in and within approximately 4 miles of the county to be revised. The points outside the county boundary are used so that contours extending to the edge of the county will match with contours in the next county. If several adjacent counties are to be revised, the points for all of the counties are extracted together.

The data points extracted for each seam are plotted on base maps and compared with the previous base map used to plot the resources for that seam. Any points on the previous map missing from the new map are added to the database. The geologist must examine the extracted points to determine which are suitable for representing the seam isopach (thickness contour), and what the correct thickness of clean, minable coal is at each location.

Records from coal test holes, mines, and some engineering borings are generally categorized, in ISGS terminology, as class I points. Class I points are suitable for classifying deposits of coal as demonstrated reserves. Records from water wells and oil test holes are class II points, which provide useful information for areas otherwise devoid of data; they not sufficiently reliable for classifying deposits of coal as demonstrated reserves. In the Geographic Information system (GIS), buffer zones 2 miles in diameter are created around each class I point. Class II points are used for resource mapping only outside this buffer because thickness measurements from water wells and oil test holes are less accurate than those from coal test holes and mines. We have found that class II points reduce the accuracy of contouring areas for which class I data are ample.

The clean, minable thickness of the coal at each location is used to construct the seam isopach. Partings of shale and other rock materials within the seam are excluded from the contoured 
thickness (Wood et al. 1983). If thick rock partings divide the seam into two or more benches, only the thicknesses of the bench(es) most likely to be mined are included in the contoured thickness. If the thickness and distribution of partings is so great that the coal is unlikely to be mined, that area of the seam is excluded from reserve calculations.

All the resources revised for this study were at depths that require underground mining. As a general rule in Illinois mines, 1 foot of parting material is the maximum considered feasible to mine for any extended area. Thinner partings are mined to recover separate benches of coal, if the tonnage of the clean coal recovered exceeds the tonnage of the parting material that must be handled (fig. A6-1a, Nokomis Coal no. 1). In this example, the resource would be mapped as the total thickness of coal (excluding the partings).

The log for the test hole, Christian County no. 857 (fig. A6-1b), shows a 9.5-foot seam that contains a 1-foot parting at 1.5 feet above the base of the seam. In this example, the parting and lower bench of coal are not likely to be mined because the tonnage recovered from the lower bench of coal would be less than the tonnage of the parting. (Parting material has a specific gravity of around 2.6; bituminous coal has a specific gravity of about 1.3.) The lower bench of coal would be minable if the parting were less than 0.8 feet thick. In this example, the resource would be mapped as 7 feet thick.

Only the upper two benches of coal, represented in the log for Christian County no. 2196 (fig. A6-1c), would be mined. The lower bench of coal would be left because the shale parting is too thick for mining; thus the mapped thickness of resources would be 5 feet. Figure A6-1d (Montgomery County no. 741) shows the entire seam to be unminable; the partings are too thick to mine, and none of the benches of coal is thick enough to mine alone. The area represented by this log would be excluded from resource calculations.

a

Nokomis Coal Co.

$$
10
$$

no. 1 (Kay 1922)

$$
\begin{array}{r}
10 \\
8 \\
6 \\
\Phi \\
\nsubseteq
\end{array}
$$

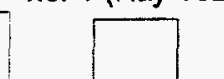

b

Christian Co. no. 857<smiles>CCC</smiles>

$$
\text { (1) }
$$<smiles>[IH2]</smiles>

\section{no. 2196}

d

Montgomery Co.

no. 741

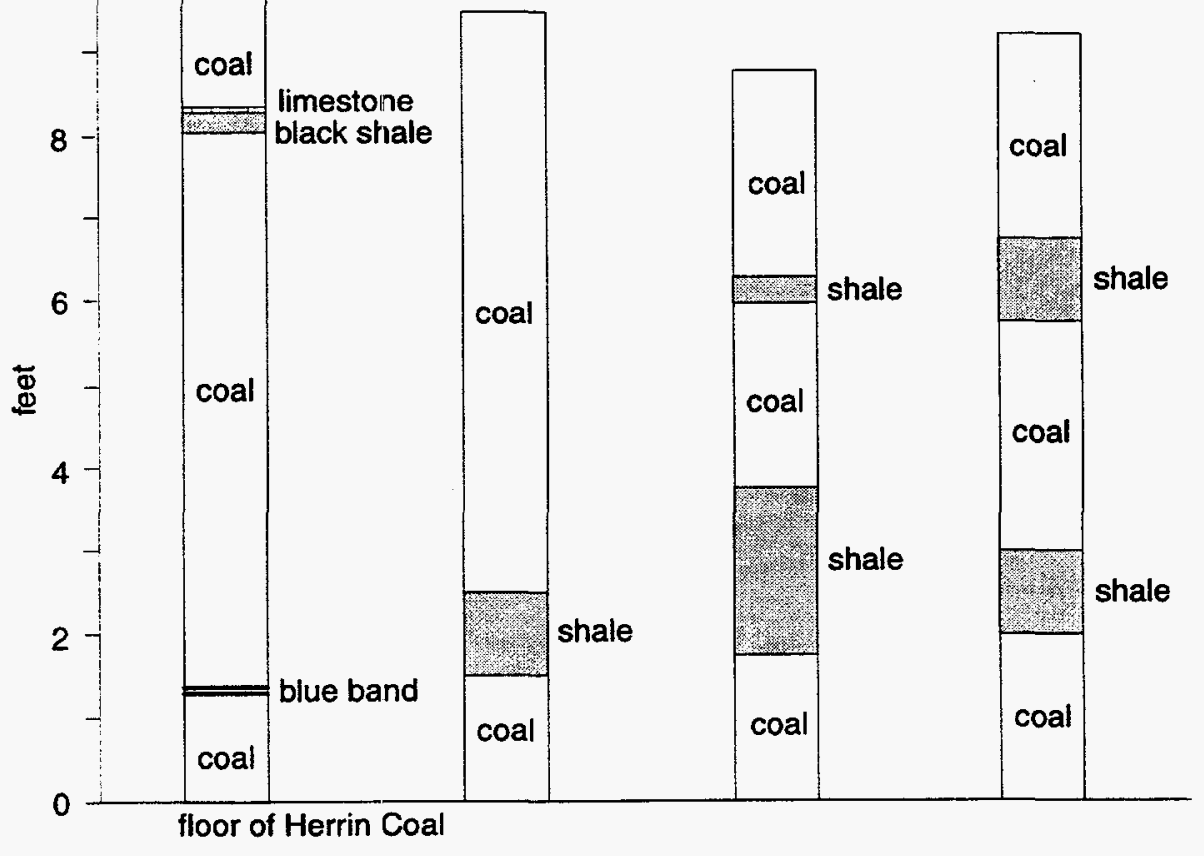

Figure A6-1 Examples of partings observed in mines or logs in the vicinity of the Nokomis Quadrangle (from Treworgy et al. 1996). 


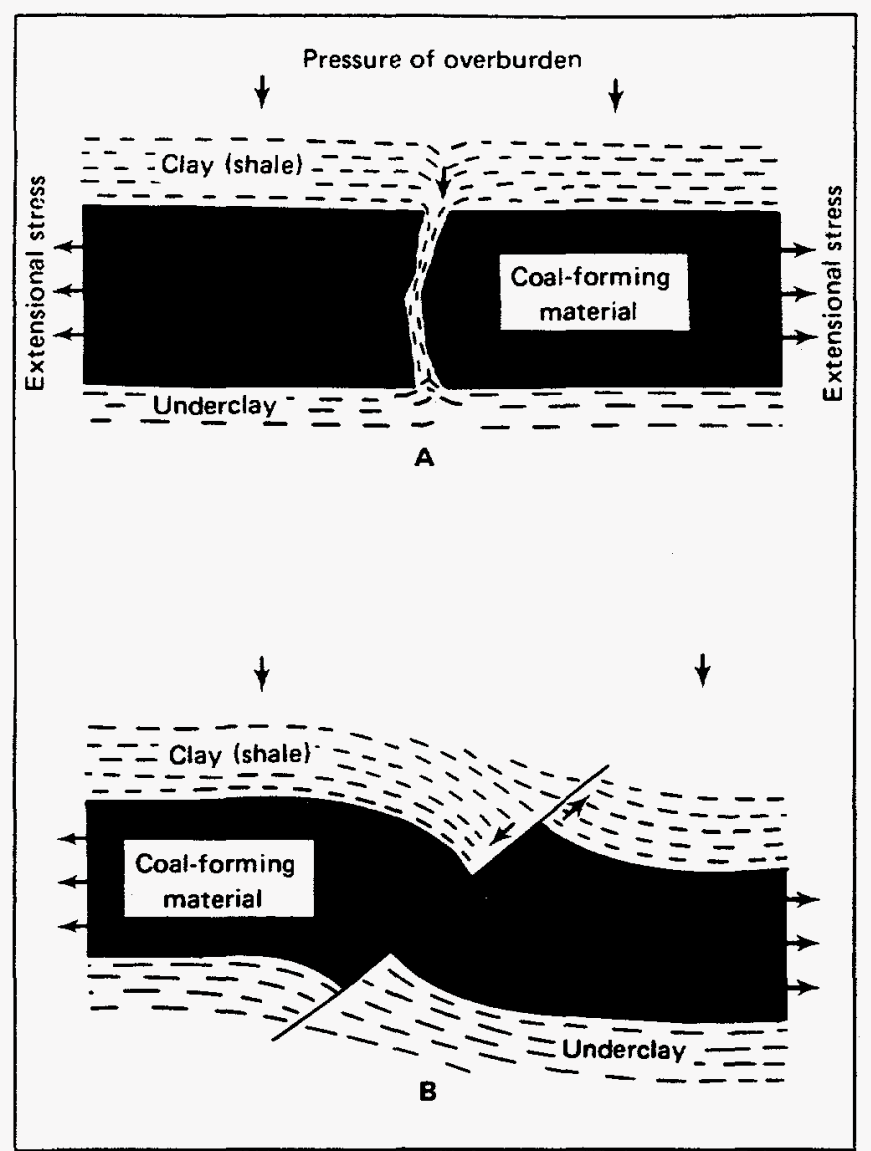

Figure A6-2 Examples of clay dikes and clay-dike faults (from Nelson, 1981).
Many drilling records report only total seam thickness and give no information on partings. Thin partings of noncoal material ( $<0.5$ inches thick) are common in Illinois coals; however, the percentage of unreported noncoal material is believed to be an insignificant source of error in estimating coal resources.

\section{Contouring of Data}

The thickness, depth, and elevation contours for each seam are created from the selected data points by using a commercial software package for contouring (Earthvision version 3.0, Dynamic Graphics inc., Alameda, California). This package operates like most contouring software in that a regularly spaced grid of nodes is superimposed on the data set, and an arithmetic function is used to extrapolate the values to be contoured from the data points to the surrounding nodes (Robinson 1982). As a final step, the software contours the area on the basis of the extrapolated values at the uniformly spaced nodes.

The results of this process vary depending upon the distance between grid nodes and the function used to extrapolate the data values to the grid. These parameters, specified by the geologist, depend upon the number and distribution of data points as well as the variability of the value being contoured. Too small a grid creates spurious detail, and too large a grid overgeneralizes the data. We experimented until we found settings that contoured our typical sets the way a geologist would have manually contoured the data. For our software, this setting was 2-D minimum tension gridding with normal tension, 1,000-foot grid spacing, and a multiple data point gridding level of four points. Thickness maps were contoured with a 0.5-foot interval at a resolution of 1:24,000. Depth maps were contoured with a 25-foot interval.

The initial set of maps must be carefully reviewed to distinguish between genuine geologic anomalies resulting from features such as faults, channels, and clay dikes, and data errors such as miscorrelations, data entry errors, and mislocation of data points. Data points indicating anomalous thickness or depth must be verified as genuine, or they are corrected or deleted. The geologist must decide whether to let the software contour geologic anomalies or to remove the data points so that these features may be contoured by hand later. Several iterations of mapping, reviewing, and modifying data may be required before a suitable set of maps is obtained.

Whether geologic anomalies are included in the resource estimate depends upon two decisions made by the geologist: (1) Are anomolies real or due to errors in the data? (2) If an anomalous feature is real and present, should it be represented on the map; that is, can it be reasonably represented at the scale of mapping? For example, abrupt thinning of a coal may indicate a local condition such as a clay dike or small fault that affects only the coal within a few feet of specific data points (fig. A6-2). These features cannot be accurately contoured at the scale of a regional resource assessment, and the affected data points should not be used by the computer in contouring 
coal thickness. Data points that penetrate normal or reverse faults are also excluded from regional resource maps; displacement from such faults in Illinois typically affects an area that is less than 100 feet wide and can only be delineated by numerous, closely spaced holes (fig. A6-3).

Data points that encounter postpeat-swamp stream channels that eroded through the coal must also be excluded from the computer processing. In most cases, there are not enough points for the computer software to delineate the complete path of the channel. Because these channels eroded the coal after it was deposited, they did not influence the development of the peat swamp and the resulting trends in coal thickness. The geologist should first allow the computer to contour the coal thickness based on the trends derived from nonchannel points. In a later step, the geologist can manually superimpose his interpretation of the channel course on the final map.

Data points penetrating channel systems that formed contemporaneously with the peat may be included in the contouring, at the discretion of the geologist. Thickness patterns of coal deposits adjacent to peat-contemporaneous channels are often complex. In some areas, the coal thins toward the channel in a regular pattern. In other areas, the coal thickens significantly, then abruptly splits into multiple thin benches. The geologist must assess each area and judge whether the software has adequately contoured the data.

\section{Merging of Data Layers and Calculating Volumes}

In the final stage of processing, the computer-generated contour maps are converted from the grid format of the contouring software to another format used by GIS software. The GIS creates reliability zones for measured, indicated, and inferred resources. Within the GIS, maps of seam thickness, depth, and reliability are merged with maps of mined areas, rank, sulfur, and heat content. Tonnages are calculated from the merged layers and stored in the database of resource and reserve data on all seams. 


\section{APPENDIX 7 Formulas for calculating sulfur, heat content, rank, and stripping ratio}

Results of coal analyses stored in the ISGS database are calculated on a dry basis. Standard formulas were used to convert to the units required for the Demonstrated Reserve Base (ASTM 1990, Wood 1983).

\section{Sulfur}

ISGS data were converted from percent sulfur to pounds of sulfur per million Btu. The basis of the Btu and total sulfur values does not matter, as long as it is the same for both (e.g, dry basis).

Pounds sulfur/million Btu $=(10,000 \times$ total sulfur $) /$ Btu per pound

\section{Heat content}

ISGS data were converted from Btu per pound (dry basis) to million Btu per ton (as-received basis).

$$
\text { Million Btu/ton }_{\text {as received }}=((100-\text { moisture }) / 100) \times\left(\text { Btu per pound }_{d r y} / 500\right)
$$

\section{Rank}

Rank was determined by ASTM's classification (D388), which uses Btu/lb on a moist, mineralmatter-free basis (mmmf). All Illinois coals are high volatile bituminous. Coals above $14,000 \mathrm{Btu} / \mathrm{lb}$ (mmmf) are high volatile A bituminous; 13,000 to 14,000 are B; and less than 13,000 are $\mathrm{C}$. Btu/lb data in the ISGS database are stored on a dry basis and were converted to a moist, mineral-matterfree basis, by using the following equation.

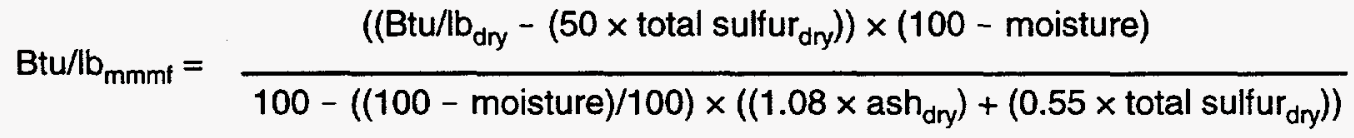

\section{Stripping ratio}

The stripping ratio is expressed in cubic yards per ton and represents the amount of overburden material that must be moved to uncover a ton of coal. The calculation in this report is based on raw coal, exclusive of partings with no allowance made for additional losses in handling and cleaning.

Cubic yards/ton $=$

(thickness of overburden (ft) $\times$ acres $\times 43,560 \mathrm{sq} f t / a c r e) / 27 \mathrm{sq} f t / c u$ yd

thickness of coal $(\mathrm{ft}) \times$ acres $\times 1,800$ tons/acre

This equation simplifies to

Cubic yards/ton $=$

thickness of overburden $(\mathrm{ft}) \times 0.896296 \mathrm{cu} \mathrm{yd} / \mathrm{ton}$

thickness of coal (ft) 